\title{
Organocatalytic Trapping of Elusive Carbon Dioxide based Heterocycles through a Kinetically Controlled Cascade Process
}

Chang Qiao, Alba Villar-Yanez, Josefine Sprachmann, Bart Limburg, Carles Bo, Arjan. W. Kleij

Submitted date: 20/05/2020 - Posted date: 22/05/2020

Licence: CC BY-NC-ND 4.0

Citation information: Qiao, Chang; Villar-Yanez, Alba; Sprachmann, Josefine; Limburg, Bart; Bo, Carles; Kleij, Arjan. W. (2020): Organocatalytic Trapping of Elusive Carbon Dioxide based Heterocycles through a Kinetically Controlled Cascade Process. ChemRxiv. Preprint. https://doi.org/10.26434/chemrxiv.12343985.v1

A conceptually novel approach is described for thesynthesis of larger-ring cyclic carbonates derived from carbon dioxide. The approach utilizes homoallylic precursors that are converted into five-membered cyclic carbonates having a beta-positioned alcohol group in one of the ring substituents. The activation of the pendent alcohol group through an $\mathrm{N}$-heterocyclic base allows for equilibration towards a thermodynamically disfavored six-membered carbonate analogue that can be conveniently trapped by an acylation agent. Various control experiments and computational analysis of this manifold are in line with a process that is primarily dictated by a kinetically controlled acylation step. This cascade process delivers an ample diversity of novel six-membered cyclic carbonates in excellent yields and chemoselectivities under remarkably mild reaction conditions. This newly developed protocol helps to expand the repertoire of CO2-based heterocycles that are otherwise difficult to generate by conventional approaches.

File list (2)

Kleij et al. 21may20_vSubmit.pdf (830.80 KiB) view on ChemRxiv - download file 


\title{
Organocatalytic Trapping of Elusive Carbon Dioxide based Heterocycles through a Kinetically Controlled Cascade Process
}

\author{
Chang Qiao, ${ }^{[a]}$ Alba Villar-Yanez, ${ }^{[a]}$ Josefine Sprachmann, ${ }^{[a]}$ Bart Limburg ${ }^{[a]}$ Carles Bo ${ }^{[a][b]}$ and \\ Arjan W. Kleij ${ }^{*[a][c]}$ \\ Dedicated to the memory of Prof. Kilian Muñiz \\ [a] C. Qiao, A. Villar-Yanez, J. Sprachmann, Dr. B. Limburg, Prof. C. Bo and Prof. A. W. Kleij Institute of Chemical Research of Catalonia (ICIQ), \\ the Barcelona Institute of Science and Technology, Av. Països Catalans 16, 43007 - Tarragona, Spain. E-mail: akleii@iciq.es \\ [b] Departament de Química Física i Inorgànica, Universitat Rovira i Virgili, Marcel.lí Domingo s/n, 43007 Tarragona, Spain \\ [c] Prof. A. W. Kleij Catalan Institute of Research and Advanced Studies (ICREA), Pg. Lluís Companys 23, 08010 Barcelona, Spain
}

Keywords: carbon dioxide • cyclic carbonates • heterocycles • homogeneous catalysis • organocatalysis

\begin{abstract}
A conceptually novel approach is described for the synthesis of larger-ring cyclic carbonates derived from carbon dioxide. The approach utilizes homoallylic precursors that are converted into fivemembered cyclic carbonates having a $\beta$-positioned alcohol group in one of the ring substituents. The activation of the pendent alcohol group through an $\mathrm{N}$-heterocyclic base allows for equilibration towards a thermodynamically disfavored six-membered carbonate analogue that can be conveniently trapped by an acylation agent. Various control experiments and computational analysis of this manifold are in line with a process that is primarily dictated by a kinetically controlled acylation step. This cascade process delivers an ample diversity of novel six-membered cyclic carbonates in excellent yields and chemoselectivities under remarkably mild reaction conditions. This newly developed protocol helps to expand the repertoire of $\mathrm{CO}_{2}$-based heterocycles that are otherwise difficult to generate by conventional approaches.
\end{abstract}

\section{Introduction}

The last decade has witnessed a spectacular development of a plethora of new catalytic processes that focus on the valorization of carbon dioxide $\left(\mathrm{CO}_{2}\right)^{[1]}$ affording organic molecules of use as precursors in fine chemical, ${ }^{[2]}$ pharmaceutical ${ }^{[3]}$ and polymer chemistry ${ }^{[4]}$ One of the most widely applied valorization routes is undoubtedly the non-reductive transformation of $\mathrm{CO}_{2}$. Catalyst engineering in this area has been mainly focusing on using both metal- ${ }^{[5]}$ and organo-catalysts ${ }^{[6]}$ for the activation of the requisite co-reactant (often cyclic ethers such as epoxides) to produce a nucleophilic intermediate species that activates $\mathrm{CO}_{2}$ followed by the formation of the desired product. The preparation of heterocyclic targets such as cyclic carbonates, ${ }^{[7]}$ carbamates $^{[8]}$ and ureas $^{[9]}$ has greatly advanced as testified by the growing complexity of these $\mathrm{CO}_{2}$-based products.

Larger-ring, typically difficult to prepare $\mathrm{CO}_{2}$ based heterocycles remain challenging targets (Scheme 1 , top). In the area of organic carbonate synthesis, methods to generate six-membered heterocycles are scarce and often rely on stoichiometric approaches. ${ }^{[10]}$ An exception is presented by the coupling reaction between oxetanes and $\mathrm{CO}_{2}$, although to date very few catalysts have been shown to be effective for these substrates, ${ }^{[11]}$ and oxetanes are much less ubiquitous than epoxides. Therefore, new concepts are required to empower the potential of such novel, functionalized heterocyclic scaffolds and widen their prospective as synthetic intermediates ${ }^{[12]}$ and polymerizable monomers. ${ }^{[13]}$ With this challenge in mind, we set out to design a new conceptual route towards the synthesis of sixmembered cyclic carbonates from simple and accessible building blocks (Scheme 1). Homoallylic 
alcohols of type $\mathbf{A}$ are ubiquitous precursors and play a significant role in organic synthesis. ${ }^{[14]}$ Their epoxidation directly affords substrates of type $\mathbf{B}$ that should be easily converted into intermediate 5membered cyclic carbonate products $\mathbf{1}$. Inspired by our previous work on substrate-controlled synthesis of organic carbonates, ${ }^{[15]}$ we envisioned that the presence of a suitable organocatalyst (base) should be able to induce isomerization between carbonates $\mathbf{1}$ and $\mathbf{1}^{\text {' }}$ with the latter being thermodynamically less stable. Selective acylation of the primary alcohol in 1' offers then a tangible route to isolate the more elusive cyclic carbonate product $\mathbf{2}$. Herein, we illustrate this successful, new and generally high-yielding route towards highly substituted six-membered carbonates of type 2 creating a superior diversity of such valuable heterocycles.

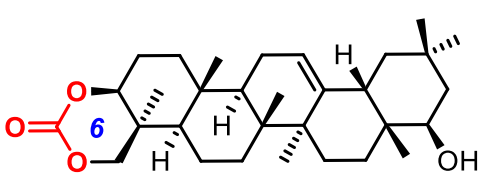

Soyasapogenol G (from melilotus messanensis)

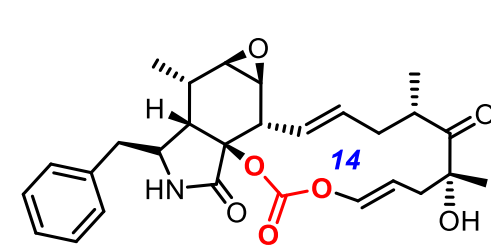

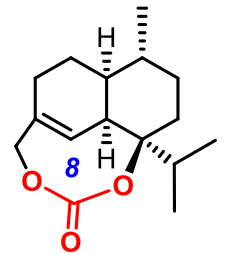

4-Muurolen-7,15-diol-

7,15-carbonate

(from fabiana imbricata)

Cytochalasin E (from rosellinia necatrix)
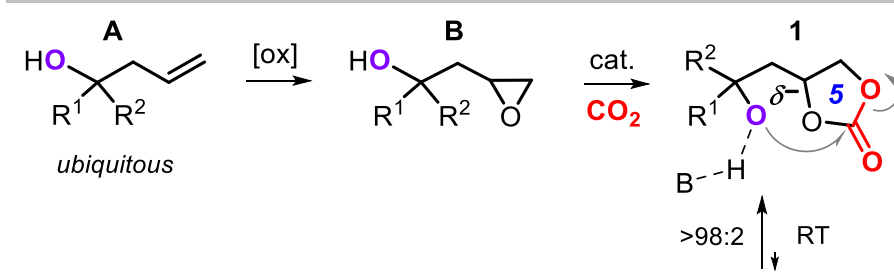

Conceptually new

Elusive carbonates

Wide diversity

Domino reactivity

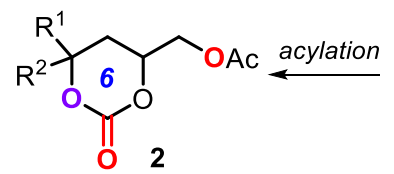

$\overbrace{0}^{2} \overbrace{0}^{1}{ }_{0}^{1}$

Scheme 1. Top: larger-ring, naturally occurring cyclic organic carbonates. Bottom: new conceptual approach towards sixmembered cyclic carbonates. B stands for a base.

\section{Results \& Discussion}

We first prepared a series of 5-membered cyclic carbonates of type 1 by employing various homoallylic alcohols (A1-A17) as precursors that are conveniently prepared from readily available ketones and allyl magnesium bromide. Epoxidation of these homoallylic compounds using $m$-CPBA at room temperature ( $\mathrm{rt}$ ) afforded the oxiranes B1-B17 with a $\beta$-hydroxy group (see the Supporting Information, SI, for details). The oxiranes B1-B17 (Scheme 2) were then used as reagents to furnish the cyclic carbonates $\mathbf{1 a - 1 q}$ typically in good yields (with some exceptions) in the presence of $\mathrm{CO}_{2}$ and

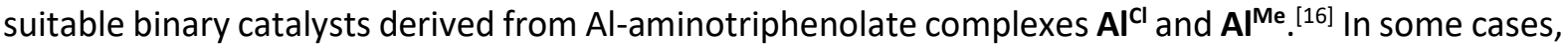
significant byproduct formation occurred, and these products were identified as substituted tetrahydrofuran derivatives (see the SI for analysis details). The observed $d r$ values for some of the 5membered cyclic carbonates are similar to the ones of their respective precursors $\mathbf{B}$, and hence supports the view that the formation of these five-membered carbonates is diastereospecific. 

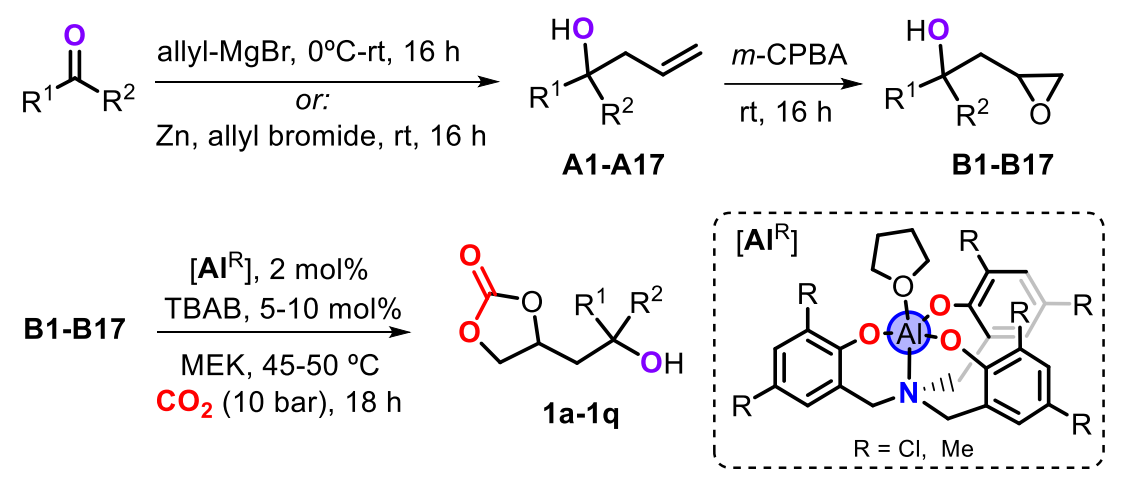
1a. $\mathrm{Al}^{\mathrm{Cl}}, \mathrm{R}^{1}=\mathrm{R}^{2}=\mathrm{Ph} ; 85 \%$
1f. $\mathrm{Al}^{\mathrm{Cl}}, \mathrm{R}^{1}=\mathrm{R}^{2}=n-\mathrm{Pr} ; 82 \%$
1b. $\mathrm{Al}^{\mathrm{Cl}}, \mathrm{R}^{1}=\mathrm{R}^{2}=p-\mathrm{OMe}-\mathrm{C}_{6} \mathrm{H}_{4} ; 99 \%$
1c. $\mathrm{Al}^{\mathrm{Cl}}, \mathrm{R}^{1}=\mathrm{R}^{2}=p-\mathrm{Me}-\mathrm{C}_{6} \mathrm{H}_{4} ; 96 \%$
1g. $\mathrm{Al}^{\mathrm{Cl}}, \mathrm{R}^{1}=\mathrm{R}^{2}=\mathrm{c}$-hexyl; $67 \%$
1d. $\mathrm{Al}^{\mathrm{Cl}}, \mathrm{R}^{1}=\mathrm{R}^{2}=p-\mathrm{Cl}-\mathrm{C}_{6} \mathrm{H}_{4} ; 87 \%$
1h. $\mathrm{Al}^{\mathrm{Cl}}, \mathrm{R}^{1} \cdots \mathrm{R}^{2}=c$-hexyl; $87 \%$
1e. $\mathrm{Al}^{\mathrm{Cl}}, \mathrm{R}^{1}=\mathrm{R}^{2}=p-\mathrm{F}-\mathrm{C}_{6} \mathrm{H}_{4} ; 85 \%$
1i. $\mathrm{Al}^{\mathrm{Cl}}, \mathrm{R}^{1} \cdots \mathrm{R}^{2}=c$-heptyl; $93 \%$
1j. $\mathrm{Al}^{\mathrm{Cl}}, \mathrm{R}^{1}=4-\mathrm{Me}-\mathrm{C}_{6} \mathrm{H}_{4}, \mathrm{R}^{2}=\mathrm{Me} ; 79 \%, d r=7: 3$

1k. $\mathrm{Al}^{\mathrm{Me}}, \mathrm{R}^{1}=\mathrm{Ph}, \mathrm{R}^{2}=\mathrm{Et} ; 73 \%, d r=7: 3$

1l. $\mathrm{Al}^{\mathrm{Me}}, \mathrm{R}^{1}=\mathrm{Ph}, \mathrm{R}^{2}=\mathrm{CF}_{3} ; 78 \%, d r=9: 1$

1m. $\mathrm{Al}^{\mathrm{Cl}}, \mathrm{R}^{1}=2,4-$ diMe- $\mathrm{C}_{6} \mathrm{H}_{4}, \mathrm{R}^{2}=\mathrm{Me} ; 46 \%, d r=7: 3$

1n. $\mathrm{Al}^{\mathrm{Cl}}, \mathrm{R}^{1}=2$-naphthyl, $\mathrm{R}^{2}=\mathrm{Me} ; 58 \%, d r=9: 1$

10. $\mathrm{Al}^{\mathrm{Cl}}, \mathrm{R}^{1}=c$-hexyl, $\mathrm{R}^{2}=\mathrm{H} ; 27 \%, d r=6: 4$

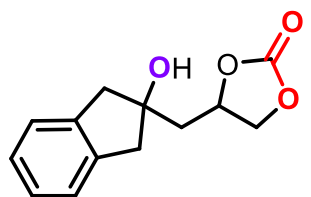

1p. $\mathbf{A l} \mathrm{Me}, 58 \%$

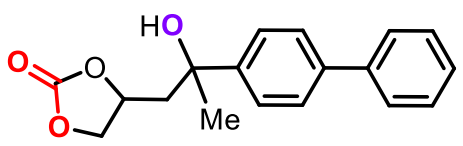

1q. $\mathbf{A l}^{\mathrm{Cl}}, 41 \%, d r=8: 2$

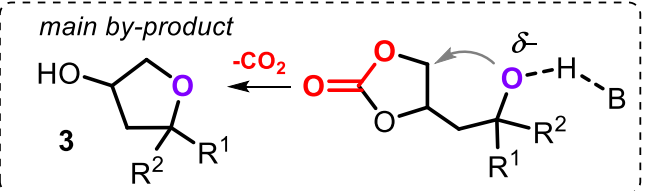

Scheme 2. Preparation of 5-membered carbonates 1a-1q from precursors B1-B17 that are prepared from homoallylic alkenes A1-A17 using either $\mathbf{A} \mathbf{I l}^{\mathrm{Cl}}$ or $\mathbf{A} \mathbf{I}^{\mathrm{Me}}$.

For the screening studies focusing on the preparation of six-membered cyclic carbonate $\mathbf{2 a}$ (Table 1 ), we chose carbonate 1a as a benchmark substrate. Various $\mathrm{N}$-heterocyclic and standard bases were examined and acetyl imidazole (Aclm) was used as acylation reagent. ${ }^{[15 c]}$ The nature of the base had a significant effect on both the yield of $\mathbf{2 a}$ and the overall chemo-selectivity. Among the eight bases tested, the $N$-heterocyclic ones (Table 1, entries 1, 2 and 4-6) gave the best results, with TBD (entry $1,64 \%)$ providing comparatively the best yield of $2 \mathbf{a}$. By further variation of the solvent and the amount of TBD (entries 9-17), the best considered conditions (entry 15; 30 mol\% TBD) offered an easy access to $2 \mathbf{a}$ in high yield. In the absence of Aclm and by using a high loading of TBD, only tetrahydrofuran derivative $3 a$ could be identified (entry 17). In the absence of TBD (entry 18), no conversion of 1a could be observed. This rt catalytic conversion of a 5 -into a 6 -membered cyclic carbonate is rather unique as the latter type of product is typically difficult to prepare under such mild conditions.

We then investigated the scope of this novel approach towards the formation of a wider diversity of 6 -membered cyclic carbonate products (Scheme 3 ) by varying the $R^{1}$ and $R^{2}$ substituents. The presence of substituted aryl groups in the carbonate substrates 1a-1e was well tolerated and provided smooth access to six-membered cyclic carbonates $2 a-2 e$ in good to excellent yields (65-91\%; gram-scale synthesis of $2 \mathrm{a}: 1.24 \mathrm{~g}$ ). The introduction of alkyl groups such as those present in the carbonate products $\mathbf{2 f - 2 i}$ also did not pose any significant issue. Apart from the combination of two equal groups, carbonate substrates with distinct $R^{1}$ and $R^{2}$ substituents $(\mathbf{1} \mathbf{j}-\mathbf{1} \mathbf{n})$ were also probed. Whereas sixmembered cyclic carbonates $\mathbf{2} \mathbf{j}, \mathbf{2} \mathbf{k}, \mathbf{2} \mathbf{m}$ and $\mathbf{2 n}$ were synthesized in good yields, the presence of a strongly electron-withdrawing $\mathrm{CF}_{3}$ group (cf., attempted preparation of $2 \mathrm{l}$ ) changed the chemo- 
selectivity in favour of the decarboxylated, $O$-acetyl protected tetrahydrofuran product 3I-Ac which was isolated in $89 \%$ (see SI for analysis details). Finally, the spiro-derivative $2 p(95 \%)$ and biphenylbased carbonate $\mathbf{2 q}(\mathbf{q} 0 \%)$ were prepared in good yields, and the identity of $\mathbf{2 p}$ was further substantiated by X-ray analysis (see the inset in Scheme 3). ${ }^{[17]}$

Next, a series of control experiments were conducted to investigate the proposed role of the pendent alcohol group in substrate 1a and the relative stability of the free alcohol carbonates (Scheme 4). In the presence of TBD only, there is no observable conversion of the 5-membered carbonate 1a into a

Table 1. Screening conditions for the conversion of cyclic carbonate $\mathbf{1 a}$ into its 6 -membered congener $\mathbf{2 a}$ under various conditions. ${ }^{[a]}$

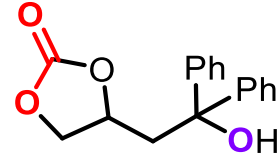

$1 \mathbf{a}$

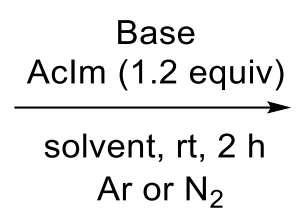

Ar or $\mathrm{N}_{2}$<smiles>CC(=O)OCC1CC(c2ccccc2)(c2ccccc2)OC(=O)O1</smiles>

$2 a$

\begin{tabular}{|c|c|c|c|c|}
\hline Entry & $\begin{array}{c}\text { Base } \\
{[\mathrm{mol} \%]}\end{array}$ & Solvent & $\begin{array}{c}\text { Conv. of 1a } \\
{[\%]^{[\mathrm{b}]}}\end{array}$ & $\begin{array}{c}\text { Yield of 2a } \\
{[\%]^{[c]}}\end{array}$ \\
\hline 1 & TBD (20) & $\mathrm{CH}_{3} \mathrm{CN}$ & 64 & 64 \\
\hline 2 & DBU (20) & $\mathrm{CH}_{3} \mathrm{CN}$ & 49 & 49 \\
\hline 3 & $\mathrm{KOH}(20)$ & $\begin{array}{l}\mathrm{CH}_{3} \mathrm{CN} \\
\mathrm{CH}_{3} \mathrm{CN}\end{array}$ & 100 & $0^{[\mathrm{d}]}$ \\
\hline 4 & DMAP (20) & $\mathrm{CH}_{3} \mathrm{CN}$ & 8 & 2 \\
\hline 5 & DBN (20) & $\mathrm{CH}_{3} \mathrm{CN}$ & 43 & 18 \\
\hline 6 & $\mathrm{DABCO}(20)$ & $\mathrm{CH}_{3} \mathrm{CN}$ & 6 & 0 \\
\hline 7 & TEA (20) & $\mathrm{CH}_{3} \mathrm{CN}$ & 6 & 0 \\
\hline 8 & $\mathrm{~K}_{2} \mathrm{CO}_{3}(20)$ & $\mathrm{CH}_{3} \mathrm{CN}$ & 16 & 0 \\
\hline 9 & TBD (20) & THF & 31 & 31 \\
\hline 10 & TBD (20) & $\mathrm{Et}_{2} \mathrm{O}$ & 84 & 22 \\
\hline 11 & TBD (20) & Toluene & 63 & 59 \\
\hline 12 & TBD (20) & DMF & 15 & 15 \\
\hline 13 & TBD (20) & $\mathrm{EtOH}$ & 21 & 3 \\
\hline 14 & TBD (20) & DCM & 53 & 53 \\
\hline 15 & TBD (30) & $\mathrm{CH}_{3} \mathrm{CN}$ & 94 & $93(91)^{[\mathrm{f}]}$ \\
\hline 16 & TBD (50) & $\mathrm{CH}_{3} \mathrm{CN}$ & 97 & $97(96)^{[f]}$ \\
\hline $17^{[\mathrm{e}]}$ & TBD (100) & $\mathrm{CH}_{3} \mathrm{CN}$ & $>99$ & $14^{[\mathrm{g}]}$ \\
\hline 18 & - & $\mathrm{CH}_{3} \mathrm{CN}$ & $<1$ & 0 \\
\hline
\end{tabular}

[a] Reaction conditions: substrate 1a $(0.10 \mathrm{mmol})$, solvent $(0.20 \mathrm{~mL}), 2 \mathrm{~h}$, under Ar or $\mathrm{N}_{2}$. [b] Conversions measured by ${ }^{1} \mathrm{H}$ NMR $\left(\mathrm{CDCl}_{3}\right)$. [c] Determined by ${ }^{1} \mathrm{H}$ NMR using mesitylene as internal standard. [d] An unidentified byproduct was formed. [e] In the absence of acetyl imidazole. [f] In brackets the isolated yield of 2a. [g] Note that 5,5-diphenyltetrahydrofuran-3-ol (3a) was isolated in $14 \%$ yield, see the SI for analysis details. Abbreviations: TBD = triazabicyclodecene, DBU = 1,8-diazabicyclo[5.4.0]-undec-7-ene, DBN = 1,5-diazabicyclo[4.3.0]non-5-ene, DABCO = 1,4diazabicyclo[2.2.2] octane, TEA = triethyl amine. 
6-membered one suggesting indeed that $\mathbf{1 a}$ is thermodynamically significantly more stable (Scheme 4a). We separately prepared acylated $\mathbf{1} \mathbf{h}$-Ac and subjected this compound to the conditions that are present at the end of the cascade process (Scheme $4 b$ ). No conversion was observed pointing at the crucial role of a free alcohol group in carbonate $1 \mathrm{~h}$ prior to equilibration of the 5 - to a 6 -membered cyclic carbonate.

Whereas 6-membered cyclic carbonate $\mathbf{2 h}$ is stable at lower temperatures, at elevated ones deprotection of the O-Ac group occurs giving the free alcohol, 5-membered cyclic carbonate $\mathbf{1 h}$ as the sole carbonate product in $40 \%$ isolated yield. ${ }^{[18]}$ Deprotection of $\mathbf{2} \mathbf{h}$ therefore leads to equilibration to

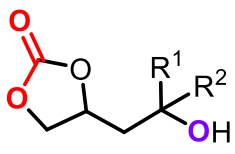

1a-1q

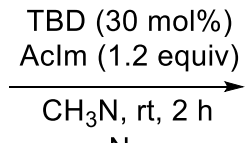

$\mathrm{N}_{2}$<smiles>[R]C(O)CC1CC([R])([R])OC(=O)O1</smiles>

$2 a-2 q$<smiles>[X]c1ccc(C2(c3ccc([X])cc3)CC(COC(C)=O)OC(=O)O2)cc1</smiles>

2a. $X=H: 91 \%{ }^{[a]}$

2b. $X=$ OMe: $83 \%$

2c. $X=$ Me: $82 \%$

2d. $X=\mathrm{Cl}: 65 \%$

2e. $X=F: 84 \%$<smiles>CC(=O)OCC1CC(C(C)C)(C(C)C)OC(=O)O1</smiles>

2f. $79 \%$

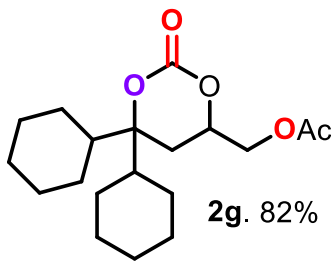<smiles>CC(=O)OCC1CC2(CCCCC2)OC(=O)O1</smiles>

2h. $85 \%$<smiles>CC(=O)OCC1CC2(CCCCCCC2)OC(=O)O1</smiles>

2i. $94 \%$<smiles>CCC1(c2ccccc2)CC(COC(C)=O)OC(=O)O1</smiles>

2k. $90 \%, d r=7: 3$<smiles>CC(=O)OCC1CC(c2ccccc2)(C(F)(F)F)OC(=O)O1</smiles>

21. $0 \%{ }^{[\mathrm{b}]}$<smiles>Cc1ccc(C2(C)CC(COCCCCO)OC(=O)O2)c(C)c1</smiles>

2m. $83 \%, d r=7: 3$<smiles>CC(=O)OCC1CC(C)(c2ccc(-c3ccccc3)cc2)CC(C)(c2ccc3ccccc3c2)OC1=O</smiles><smiles>CC(=O)OCC1CC2(Cc3ccccc3C2)OC(=O)O1</smiles>

2p. $95 \%$

Scheme 3. Scope of six-membered cyclic carbonates $\mathbf{2 a - 2 q}$ using $\mathbf{1 a - 1 q}$ as precursors and the reaction conditions of entry 15 in Table 1. [a] Gram-scale synthesis of $2 \mathrm{a}$ using $5 \mathrm{mmol}$ 1a: yield $1.24 \mathrm{~g}, 76 \%$. [b] The acetyl-protected tetrahydrofuran product $\mathbf{3 I}$-Ac was isolated in $89 \%$ yield, see $\mathrm{SI}$ for analysis data. 
5-membered cyclic carbonate $\mathbf{1 h}$ reinforcing the view that the free alcohol cyclic carbonate equilibrium is under thermodynamic control.

To further probe the role of the alcohol group, 5-membered cyclic carbonate 10 comprising a secondary (instead of tertiary) $\mathrm{OH}$ was examined. By following the optimized conditions (Table 1, entry $15)$, acetylated $10-A c(50 \%)$ was isolated as the major carbonate product and only a trace amount of the 6-membered carbonate was noted. This result can be anticipated as secondary alcohols should be much more susceptible towards protection largely precluding competitive carbonate equilibration to the unprotected 6-membered carbonate (cf., Scheme 1: $1 \rightarrow \mathbf{1}^{\prime}$ ) and subsequent acylation.

(a)<smiles>O=C1OCC(CC(O)(c2ccccc2)c2ccccc2)O1</smiles>

$1 a$

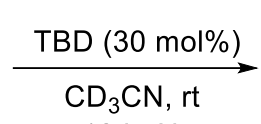

$12 \mathrm{~h}, \mathrm{~N}_{2}$<smiles>O=C1OC(CO)CC(c2ccccc2)(c2ccccc2)O1</smiles>

not detected

(b)

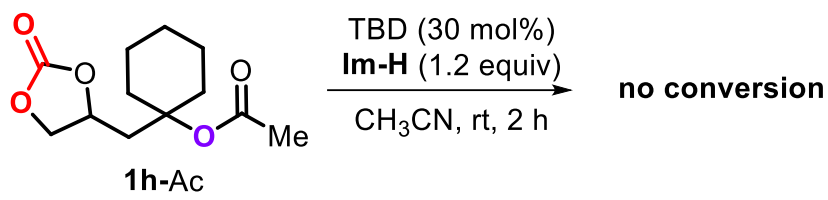

(c)<smiles>CC(=O)OCC1CC2(CCCCC2)OC(=O)O1</smiles>

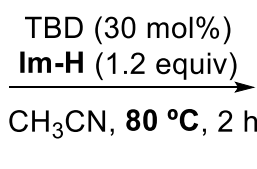<smiles>O=C1CC(CC2(O)CCCCC2)CO1</smiles>

conversion $45 \%$ 1h. $40 \%$

(d)<smiles>O=C1OCC(CC(O)C2CCCCC2)O1</smiles>

10

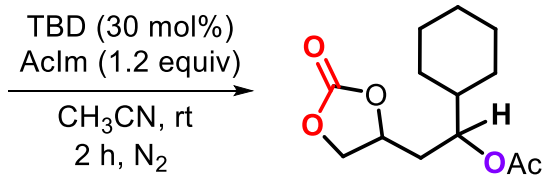

10-Ac, $50 \%$

(trace of six-membered)

Scheme 4. Various control experiments.

To further shed light on the mechanism, density functional theory (DFT) calculations were carried out (Figure 1). ${ }^{[19]}$ DFT calculations were performed using $\omega$ B97X-D functional and the $6-311 G^{* *}$ basis set. All structures in this study were calculated with the Gaussian16 program. To obtain results as close as possible to reality, all calculations were performed at $298 \mathrm{~K}$ (room temperature) and an acetonitrile solvent model SMD was used. Further details are provided in the supporting information. The conversion of $1 \mathbf{a}$ into $\mathbf{2 a}$ was examined as a representative case.

The overall cascade process (Figure 1) can be best described as two consecutive reactions. The first one is the conversion of the five-membered carbonate $\mathbf{5 M C C}-\mathbf{O H}(\mathbf{1 a})$ into the six-membered one named $\mathbf{6 M C C}-\mathbf{O H}$, while the second step involves the protection of the alcohol of $6 \mathrm{MCC}-\mathrm{OH}$ using acetyl imidazole $(\mathrm{Aclm})$ leading to the final product $\mathbf{2 a}$. The first part of the mechanism only involves $1 \mathrm{a}$ and TBD with AcIm as spectator.

First, the tertiary alcohol in 5MCC-OH is deprotonated by TBD through TS1 obtaining 5MCC-O and TBD- $\mathrm{H}^{+}$. The alkoxide group in $\mathbf{5 M C C}-\mathbf{O}$ subsequently approaches the carbonate carbon center and generates intermediate $\mathbf{5 M C C}-$ Int. From here, an isomerisation of 5MCC-Int to $\mathbf{6 M C C}-\mathbf{I n t} \mathbf{1}$ takes place via TS2. This second step needs the presence of TBD- $\mathrm{H}^{+}$as to induce a closer interaction between the 


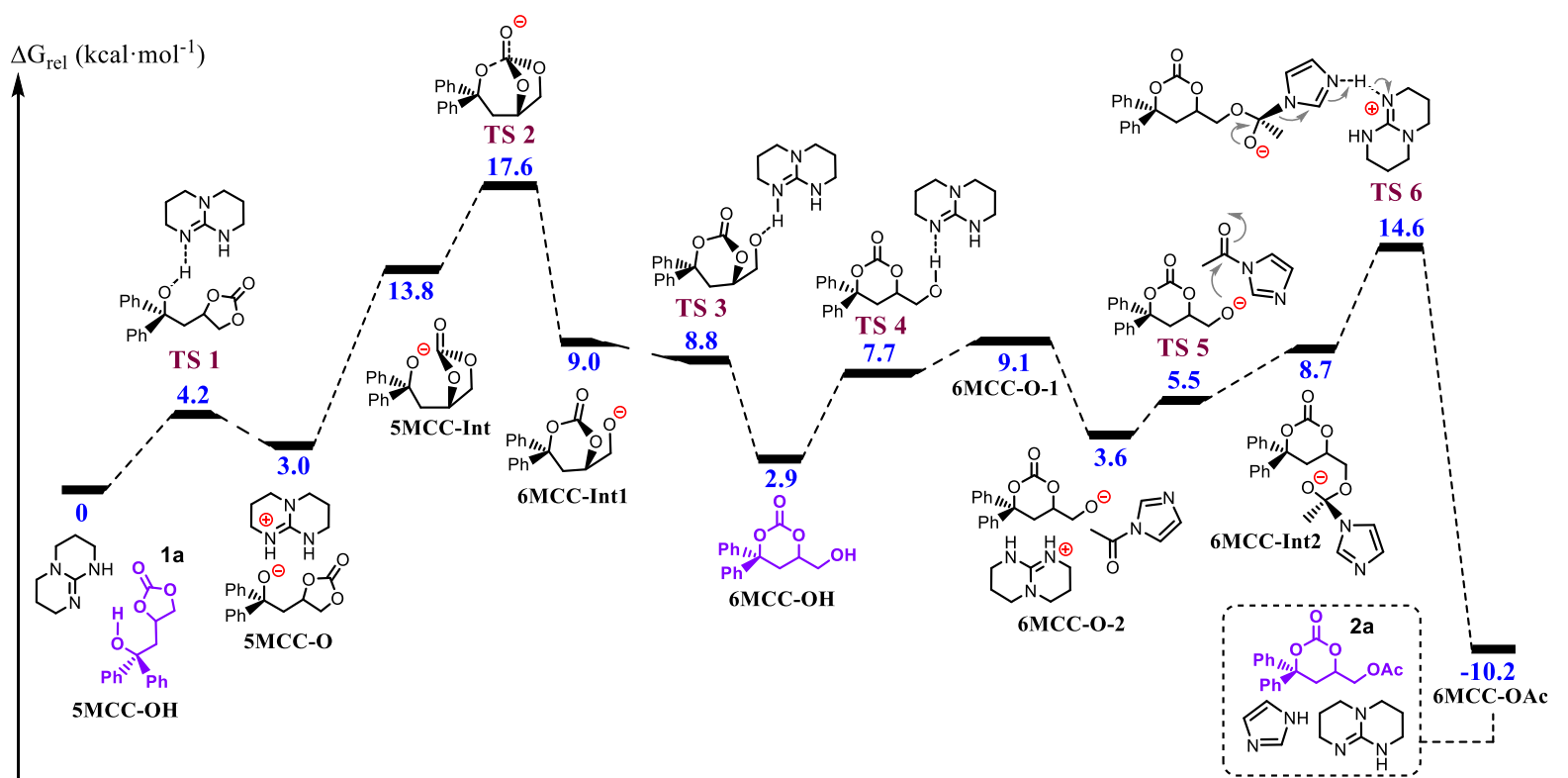

Figure 1. Relative Gibbs free energy profile in $\mathrm{kcal} \cdot \mathrm{mol}^{-1}$ for the formation of acylated six-membered cyclic carbonate $2 \mathrm{a}$ from five-membered 1a using TBD as catalyst and acetyl imidazole as acylating agent.

alkoxide and the carbonyl in 5MCC-Int thus enabling the opening of the five-membered ring generating six-membered $6 \mathrm{MCC}-\mathrm{Int} 1$. This transformation has an energetic span of $17.6 \mathrm{kcal} \cdot \mathrm{mol}^{-1}$ and supports the feasibility of all steps at room temperature. Then, the latter intermediate is converted into $6 \mathrm{MCC}-\mathrm{OH}$ through proton transfer from TBD- $\mathrm{H}^{+}$(TS3) and produces the six-membered carbonate which contains a primary alcohol. This is an important step since the conformational change while forming TS3 positions the alkoxide group away from the carbonate carbon avoiding (to some extent) a back-reaction to $\mathbf{5 M C C}-$ Int1. Importantly, $\mathbf{6 M C C}-\mathbf{O H}$ is computed to be thermodynamically significantly less stable than $\mathbf{5 M C C}-\mathrm{OH}$ (nearly $3 \mathrm{kcal} \cdot \mathrm{mol}^{-1}, \mathrm{~K}_{\text {eq }}=7.5 \times 10^{-3}$ ) and corroborates with the observation that an NMR mixture of $2 a$ and TBD ( $c f$. ., Scheme $4 a+c)$ did not show any sign of 6 MCC$\mathrm{OH}$. In order to be able to isolate the six-membered carbonate, O-protection by AcIm is thus crucial.

The second part of the cascade process describes the acylation of the primary alcohol in $6 \mathrm{MCC}-\mathrm{OH}$ (Figure 1). This O-protection using Aclm is catalyzed by TBD affording 6MCC-OAc (2a) as a thermodynamically and kinetically stable product. The acylation process occurs in three steps. The first one is the deprotonation of the primary alcohol in 6MCC-OH by TBD (via TS4) generating intermediate 6MCC-0-1 and TBD- $\mathrm{H}^{+}$. Notably, 6MCC-Int1 is different from 6MCC-0-1 in that the alkoxide group is located nearer the carbonate carbon center of 6MCC- Int1. This larger separation present in ternary intermediate 6 MCC-O-2 and facilitated by TBD- $\mathrm{H}^{+}$allows the nucleophilic alkoxide to attack the carbonyl fragment in Aclm through TS5 and furnishes intermediate 6MCC-Int2. As a consequence, the carbonyl carbon of Aclm undergoes a change from $\mathrm{sp}^{2}$ to $\mathrm{sp}^{3}$ hybridization. Finally, TBD- $\mathrm{H}^{+}$transfers a proton to the outer nitrogen atom of the imidazole group (TS6) thus provoking an electronic rearrangement that allows for the generation of the final product 6MCC-OAC (2a) and Im$\mathrm{H}$ as by-product while regenerating TBD. The highest barrier (TS6) of the acylation process is located at $14.6 \mathrm{kcal} \cdot \mathrm{mol}^{-1}$ and is substantially lower than the energetic requirement for the isomerization of $5 \mathrm{MCC}-\mathrm{OH}$ to $\mathbf{6 M C C}-\mathbf{O H}$. This isomerization appears to be rate-limiting, and the final product $6 \mathrm{MCC}$ OAc (2a) is thermodynamically more stable than $1 \mathrm{a}$ by $10.2 \mathrm{kcal} \cdot \mathrm{mol}^{-1}$.

Since all intermediates are in dynamic equilibrium, O-protection seems to make the overall cascade process irreversible at ambient temperature. To substantiate that hypothesis, we also computed the acylation of the starting carbonate $5 \mathrm{MCC}-\mathrm{OH}$ (1a) through the same pathway that leads to 6MCC-OAC (2a). Interestingly, the acetylated carbonate 5MCC-OAc has a substantially higher free energy than 
6MCC-OAC (1.8 and $-10.2 \mathrm{kcal} \cdot \mathrm{mol}^{-1}$, respectively) but the difference in activation barrier $\left(\Delta \Delta \mathrm{G}^{\ddagger}\right)$ of both acylation processes is markedly different (see Figure S1). At rt, the O-protection in $\mathbf{5 M C C}-\mathbf{O H}$ (having a tertiary alcohol) is energetically not competitive with the 5-to-6 carbonate isomerization/acylation cascade with a $\Delta \Delta \mathrm{G}^{\ddagger}$ of $7.2 \mathrm{kcal} \cdot \mathrm{mol}^{-1}$. Therefore, key to formation of the protected product $\mathbf{6 M C C}-\mathbf{O A c}$ is a kinetic differentiation between both alcohol protection pathways allowing to selectively trap the acylated six-membered carbonate $\mathbf{2} \mathbf{a}$ in high isolated yield.

\section{Conclusion}

In summary, we here present a unique organocatalytic manifold for the formation of elusive 6membered heterocycles at room temperature. The six-membered cyclic carbonates that are attained this way are highly versatile and allow for the presence of several alkyl and aryl ring substituents. Computational analysis complemented by control experiments emphasize the importance of kinetic differentiation in pendent alcohol protection as a way to isolate otherwise difficult to prepare $\mathrm{CO} 2$ based heterocycles through a unique cascade process.

\section{Acknowledgements}

We thank the CERCA Program/Generalitat de Catalunya, ICREA, the Spanish MINECO (CTQ201788920-P and CTQ2017-88777-R) and AGAUR (2017-SGR-232 and 2017-SGR-290) for financial support.

C. Q. acknowledges the Chinese Research Council for a predoctoral fellowship (2018-06200078) and

B. L. thanks the Marie Curie COFUND/ProBIST postdoctoral fellowship program (grant agreement 754510). A.V. thanks MINECO for an FPI predoctoral fellowship.

\section{References}

[1] a) J. Artz, T. E. Müller, K. Thenert, J. Kleinekorte, R. Meys, A. Sternberg, A. Bardow, W. Leitner, Chem. Rev. 2018, 118, 434-504; b) S. Liu, L. R. Winter, J. G. Chen, ACS Catal. 2020, 10, 2855-2871; c) M. B. Ross, P. de Luna, Y. Li, C.-T. Dinh, D. Kim, P. Yang, E. H. Sargent, Nat. Catal. 2019, 2, 648658; d) A. Goeppert, M. Czaun, J.-P. Jones, G. K. Surya Prakash, G. A. Olah, Chem. Soc. Rev. 2014, 43, 7995-8048.

[2] a) Q. Liu, L. Wu, R. Jackstell, M. Beller, Nat. Commun. 2015, 6, 5933; b) W. Guo, J. E. Gómez, À. Cristòfol, J. Xie, A. W. Kleij, Angew. Chem. Int. Ed. 2018, 57, 13735-13747; c) L. Song, Y.-X. Jiang, Z. Zhang, Y.-Y. Gui, X.-Y. Zhou, D.-G. Yu, Chem. Commun. 2020, DOI: 10.1039/DOCC00547A.

[3] a) A. Tortajada, F. Juliá-Hernández, M. Börjesson, T. Moragas, R. Martin, Angew. Chem. Int. Ed. 2018, 57, 15948-15982; b) W. Guo, V. Laserna, J. Rintjema, A. W. Kleij, Adv. Synth. Catal. 2016, 358, 1602-1607; c) D. U. Nielsen, X.-M. Hu, K. Daasbjerg, T. Skrydstrup, Nat. Catal. 2018, 1, 244254.

[4] For some selected examples: a) A. J. Kamphuis, F. Picchioni, P. P. Pescarmona, Green Chem. 2019, 21, 406-448; b) B. Grignard, S. Gennen, C. Jérôme, A. W. Kleij, C. Detrembleur, Chem. Soc. Rev. 2019, 48, 4466-4514; c) S. J. Poland, D. J. Darensbourg, Green Chem. 2017, 19, 4990-5011; d) S. Paul, Y. Zhu, C. Romain, R. Brooks, P. K. Saini, C. K. Williams, Chem. Commun. 2015, 51, 64596479.

[5] a) R. Rajjak Shaikh, S. Pornpraprom, V. D’Elia, ACS Catal. 2018, 8, 419-450; b) J. W. Comerford, I. D. V. Ingram, M. North, X. Wu, Green Chem. 2015, 17, 1966-1987; c) C. Martín, G. Fiorani, A. W. Kleij, ACS Catal. 2015, 5, 1353-1370.

[6] a) G. Fiorani, W. Guo, A. W. Kleij, Green Chem. 2015, 17, 1375-1389; b) M. Alves, B. Grignard, R. Mereau, C. Jerome, T. Tassaing, C. Detrembleur, Catal. Sci. Technol. 2017, 7, 2651-2684; for recent original work: c) N. Liu, Y.-F. Xie, C. Wang, S.-J. Li, D. Wei, M. Li, B. Dai, ACS Catal. 2018, 8, 9945-9957.

[7] For some illustrative, recent examples: a) G. Fiorani, M. Stuck, C. Martín, M. Martínez-Belmonte, E. Martin, E. C. Escudero-Adán, A. W. Kleij, ChemSusChem 2016, 9, 1304-1311; b) H. Zhou, H. 
Zhang, S. Mu, W.-Z. Zhang, W.-M. Ren, X.-B. Lu, Green Chem. 2019, 21, 6335-6341; c) L. Longwitz, J. Steinbauer, A. Spannenberg, T. Werner, ACS Catal. 2018, 8, 665-672.

[8] a) B. Yu, L.-N. He, ChemSusChem 2015, 8, 52-62; for some recent original examples: b) R. Yousefi, R. Yousefi, T. J. Struble, J. L. Payne, M. Vishe, N. D. Schley, J. N. Johnston, J. Am. Chem. Soc. 2019, $141,618-625$; c) J. K. Mannisto, A. Sahari, K. Lagerblom, T. Niemi, M. Nieger, G. Sztanó, T. Repo, Chem. Eur. J. 2019, 25, 10284-10289.

[9] a) M. Tamura, K. Noro, M. Honda, Y. Nakagawa, K. Tomishige, Green Chem. 2013, 15, 1567-1577; b) J. Hwang, D. Han, J. J. Oh, M. Cheong, H.-J. Koo, J. S. Lee, H. S. Kim, Adv. Synth. Catal. 2019, 361, 297-306.

[10] a) T. M. McGuire, E. M. López-Vidal, G. L. Gregory, A. Buchard, J. $\mathrm{CO}_{2}$ Util. 2018, 27, 283-288; b) G. L. Gregory, M. Ulmann, A. Buchard, RSC Adv. 2015, 5, 39404-39408; c) M. Honda, M. Tamura, K. Nakao, K. Suzuki, Y. Nakagawa, K. Tomishige, ACS Catal. 2014, 4, 1893-1896; d) T. Hirose, S. Shimizu, S. Qu, H. Shitara, K. Kodama, L. Wang, RSC Adv. 2016, 6, 69040-69044; using a stoichiometric iodine source: e) B. A. Vara, T. J. Struble, W. Wang, M. C. Dobish, J. N. Johnston, J. Am. Chem. Soc. 2015, 137, 7302-7305. See also: f) A. Hosseinian, S. Farshbaf, R. Mohammadi, A. Monfaredc, E. Vessally, RSC Adv. 2018, 8, 17976-17988.

[11] a) C. J. Whiteoak, E. Martin, M. Martínez Belmonte, J. Benet-Buchholz, A. W. Kleij, Adv. Synth. Catal. 2012, 354, 469-476; b) J. Rintjema, W. Guo, E. Martin, E. C. Escudero-Adán, A. W. Kleij, Chem. Eur. J. 2015, 21, 10754-10762; c) B. R. Buckley, A. P. Patel, K. G. Upul Wijayantha, Eur. J. Org. Chem. 2014, 474-478; d) D. J. Darensbourg, A. Horn, Jr; A. I. Moncada, Green Chem. 2010, $12,1376-1379$.

[12] a) J. Vaitla, Y. Guttormsen, J. K. Mannisto, A. Nova, T. Repo, A. Bayer, K. H. Hopmann, ACS Catal. 2017, 7, 7231-7244; b) B. D. W. Allen, C. P. Lakeland, J. P. A. Harrity, Chem. Eur. J. 2017, 23, 1383013857. See also ref. $2 b$.

[13] For selected examples: a) G. L. Gregory, G. Kociok-Köhn, A. Buchard, Polym. Chem. 2017, 8, 20932104; b) G. L. Gregory, L. M. Jenisch, B. Charles, G. Kociok-Köhn, A. Buchard, Macromolecules 2016, 49, 7165-7169; c) P. Brignou, J.-F. Carpentier, S. M. Guillaume, Macromolecules 2011, 44, 5127-5135; d) D. J. Darensbourg, A. I. Moncada, S.-H. Wei, Macromolecules 2011, 44, 2568-2576; e) D. J. Darensbourg, A. I. Moncada, Macromolecules 2010, 43, 5996-6003.

[14] For some recently developed procedures: a) M. Wadamoto, H. Yamamoto, J. Am. Chem. Soc. 2005, 127, 14556-14557; b) G.-L. Chai, B. Zhu, J. Chang, J. Org. Chem. 2019, 84, 120-127; d) Y. Zhang, N. Li, N. Goyal, G. Li, H. Lee, B. Z. Lu, C. H. Senanayake, J. Org. Chem. 2013, 78, 5775-5781.

[15] a) J. Rintjema, R. Epping, G. Fiorani, E. Martín, E. C. Escudero-Adán, A. W. Kleij, Angew. Chem. Int. Ed. 2016, 55, 3972-3976; b) V. Laserna, E. Martin, E. C. Escudero-Adán, A. W. Kleij, ACS Catal. 2017, 7, 5478-5482; c) S. Sopeña, M. Cozzolino, C. Maquilón, E. C. Escudero-Adán, M. Martínez Belmonte, A. W. Kleij, Angew Chem Int Ed. 2018, 57, 11203-11207; d) R. Huang, J. Rintjema, J. González-Fabra, E. Martín, E. C. Escudero-Adán, C. Bo, A. Urakawa, A. W. Kleij, Nat. Catal. 2019, 2, 62-70; e) C. Maquilón, B. Limburg, V. Laserna, D. Garay-Ruiz, J. González-Fabra, C. Bo, M. Martínez Belmonte, E. C. Escudero-Adán, A. W. Kleij, Organometallics 2020, 39, 1642-1651.

[16] For the first use of the Al-complexes in cyclic carbonate synthesis: a) C. J. Whiteoak, N. Kielland, V. Laserna, E. C. Escudero-Adán, E. Martin, A. W. Kleij, J. Am. Chem. Soc. 2013, 135, 1228-1231; b) C. J. Whiteoak, N. Kielland, V. Laserna, F. Castro-Gómez, E. Martin, E. C. Escudero-Adán, C. Bo, A. W. Kleij, Chem. Eur. J. 2014, 20, 2264-2275.

[17] For details of the structure of $2 p$, see CCDC-1997736.

[18] Note that beside the 5 -membered carbonate product $\mathbf{1 h}$ also substantial amounts of a

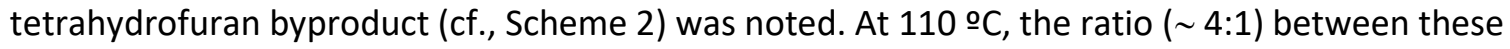
products further changed in favour of the latter.

[19] For fast scans in the potential energy surface the XTB program developed by Grimme was used, see ref. 20. This program allows the scanning of one or more distances, angles and dihedral angles at the same time or sequentially, giving a general idea of each structure. Furthermore, it performs meta-dynamics simulations using the root-mean-square deviation (RMSD) in Cartesian space as 
a collective variable. Full access to the computational data is provided through: http://dx.doi.org/10.19061/iochem-bd-1-171.

[20] a) S. Grimme, C. Bannwarth, P. Shushkov, J. Chem. Theory Comput. 2017, 13, 1989-2009. See also:

b) J.-D. Chai, M. Head-Gordon, Phys. Chem. Chem. Phys. 2008, 10, 6615-6620. 



\section{Supporting Information For:}

\section{Organocatalytic Trapping of Elusive Carbon Dioxide based Heterocycles through a Kinetically Controlled Cascade Process}

Chang Qiao, ${ }^{[a]}$ Alba Villar-Yanez, ${ }^{[a]}$ Josefine Sprachmann, ${ }^{[a]}$ Bart Limburg, ${ }^{[a]}$ Carles $\mathrm{Bo}^{[\mathrm{a}][\mathrm{b}]}$ and Arjan W. Kleij ${ }^{\star[a][c]}$

\footnotetext{
[a] C. Qiao, A. Villar-Yanez, J. Sprachmann, Dr. B. Limburg, Prof. C. Bo and Prof. A. W. Kleij Institute of Chemical Research of Catalonia (ICIQ), the Barcelona Institute of Science and Technology, Av. Països Catalans 16, 43007 - Tarragona, Spain. E-mail: akleij@iciq.es

[b] Departament de Química Física i Inorgànica, Universitat Rovira i Virgili, Marcel-lí Domingo s/n, 43007 Tarragona, Spain

[c] Prof. A. W. Kleij

Catalan Institute of Research and Advanced Studies (ICREA), Pg. Lluís Companys 23, 08010 Barcelona, Spain.
}

\section{Contents:}

Page S2: General comments

Page S3: Experimental procedures for the synthesis of the homoallylic epoxides B1-B17

Page S6: Experimental procedures for the synthesis of the 5-membered carbonates 1a-1q

Page S7: Experimental procedure for the synthesis of the 6-membered carbonates $\mathbf{2 a - 2 q}$

Page S8: Experimental procedure for the synthesis of $\mathbf{1 h}-\mathrm{Ac}$

Page S9: Qualitative reactions between $\mathbf{A l}^{\mathbf{C l}}$ and epoxy alcohol B1

Page S10: Characterization data for all new and relevant compounds

Page S37: References

Page S38: IR, ${ }^{1} \mathrm{H}$ NMR, ${ }^{13} \mathrm{C}$ NMR and ${ }^{19} \mathrm{~F}$ NMR spectra

Page S151: X-ray molecular structure of 2p

Page S152: Computational acylation of 5MCC-OH (1a)

Page S153: Relative Gibbs free energy and potential energy profiles

Page S154: Visual description of the mechanism leading to 6MCC-OAc 


\section{S2: General comments}

All reagents were used as received from commercial suppliers (Aldrich, Acros or TCI) unless stated otherwise. Carbon dioxide was purchased from PRAXAIR and used without further purification. Solvents were dried using an Innovative Technology PURE SOLV solvent purification system. NMR spectra were recorded on Bruker AV-300, AV400 or AV-500 spectrometers. The residual solvent signals were used as references for ${ }^{1} \mathrm{H}$ and ${ }^{13} \mathrm{C}$ NMR spectra $\left(\mathrm{CDCl}_{3}: \delta_{\mathrm{H}}=7.26 \mathrm{ppm}, \delta_{\mathrm{C}}=77.16 \mathrm{ppm}, \mathrm{CD}_{3} \mathrm{CN}: \delta_{\mathrm{H}}=1.94\right.$ ppm, $\left.\delta_{\mathrm{C}}=1.32 \mathrm{ppm}\right) .{ }^{19} \mathrm{~F}$ NMR spectra were not calibrated by an internal reference. FTIR measurements were carried out on a Bruker Optics FTIR-ATR TR0 spectrometer. Exact mass analyses and X-ray diffraction studies were performed by the Research Support Area (RSA) at ICIQ. 


\section{S3: Experimental procedures for the synthesis of the homoallylic epoxides}

\section{Method A}

The starting ketone or aldehyde (10 mmol) was added in a $50 \mathrm{~mL}$ oven-dried Schleck flask under nitrogen, and then $10 \mathrm{~mL}$ of dry THF was added via a syringe. Allylmagnesium bromide (12 mL, 1.2 equiv, $1.0 \mathrm{M} \mathrm{Et}_{2} \mathrm{O}$ solution) was added dropwise at $0{ }^{\circ} \mathrm{C}$ using an ice bath. The reaction was stirred at room temperature for $16 \mathrm{~h}$, then quenched with saturated $\mathrm{NH}_{4} \mathrm{Cl}(\mathrm{aq})$ and extracted with $\mathrm{Et}_{2} \mathrm{O}(3 \times 30 \mathrm{~mL})$. The combined organic layers were washed with brine, dried over $\mathrm{Na}_{2} \mathrm{SO}_{4}$, filtered, and then concentrated to obtain the corresponding homoallylic alcohol.

The homoallylic alcohols were used without further purification unless stated otherwise. The latter were dissolved in DCM (50 mL) at $0{ }^{\circ} \mathrm{C}$ and $m$-CPBA (1.1 eq., $11 \mathrm{mmol}, 2.5$ g) was added. The mixture was allowed to warm to room temperature and was stirred for $16 \mathrm{~h}$. The reaction mixture was washed with $\mathrm{NaHCO}_{3}(4 \times 30 \mathrm{~mL})$ and dried over $\mathrm{Na}_{2} \mathrm{SO}_{4}$. The solvent was removed in vacuo and the crude product was purified by flash chromatography employing $5 \%$ - 25\% EA in hexane as eluent. Note: EA stands for ethyl acetate. 


\section{Method B}

To a stirred suspension of cyclohexanone ( $0.98 \mathrm{~g}, 10 \mathrm{mmol}, 1.0$ equiv), zinc powder (976 mg, 15 mmol, 1.5 equiv), and ammonium acetate (1.156 g, 15 mmol, 1.5 equiv) in THF (40.0 mL, $0.25 \mathrm{M}$ ) at $0{ }^{\circ} \mathrm{C}$ was added allyl bromide (1.3 mL, $15 \mathrm{mmol}, 1.5$ equiv) dropwise over $1 \mathrm{~min} .{ }^{[1]}$ After stirring for $10 \mathrm{~min}$, the reaction mixture was quenched at 0 ${ }^{\circ} \mathrm{C}$ by addition of $20 \mathrm{~mL}$ of saturated aqueous $\mathrm{NaHCO}_{3}$ and allowed to warm to room temperature over $20 \mathrm{~min}$. The mixture was then transferred to a separation funnel together with $\mathrm{Et}_{2} \mathrm{O}(30 \mathrm{~mL})$ and $\mathrm{H}_{2} \mathrm{O}(30 \mathrm{~mL})$. After separation of the organic layer, the aqueous one was extracted with $\mathrm{Et}_{2} \mathrm{O}(3 \times 20 \mathrm{~mL})$. The organic layers were combined, dried over $\mathrm{Na}_{2} \mathrm{SO}_{4}$ and evaporated under reduced pressure to yield homoallylic alcohol A8 as a colorless oil.

The homoallylic alcohol A8 was used without further purification. The following epoxidation process was similar to the one described in Method A. The product, B8, was isolated as a light yellow oil using as eluent $10 \%$ - 25\% EA in hexane. Yield: 86\%. 


\section{Method C}

To a suspension of zinc powder (1.3 g, $20 \mathrm{mmol}, 2$ equiv) in dry THF (40.0 mL) at rt under nitrogen was added allyl bromide (2.42 g, 20 mmol, 2 eqiuiv). ${ }^{[2]}$ The reaction mixture was refluxed for $2 \mathrm{~min}$, and then cooled to rt. The ketone (1.34 g, $10 \mathrm{mmol}, 1$ equiv) was added dropwise to the mixture via a syringe. The mixture was stirred for 16 h, quenched with saturated $\mathrm{NH}_{4} \mathrm{Cl}(\mathrm{aq})$ and extracted with $\mathrm{Et}_{2} \mathrm{O}(3 \times 30 \mathrm{~mL})$. The combined organic layers were washed with brine, dried over $\mathrm{Na}_{2} \mathrm{SO}_{4}$, filtered, concentrated and then purified by flash chromatography employing $3 \%-10 \%$ EA in hexane as eluent to obtain homoallylic alcohol A10.

The following epoxidation process was similar to the one described in Method A. The product B10 was isolated as a light yellow oil using as eluent $5 \%$ - 10\% EA in hexane. Yield: 89\%. 


\section{S6: Experimental procedures for the synthesis of the 5-membered carbonates 1a-1q}

The non-commercial cyclic carbonates ${ }^{[3,4]}$ and $\mathrm{Al}(\mathrm{III})$ aminotriphenolate complexes $\mathbf{A l}^{\mathbf{C l}}$ and $\mathbf{A} \mathbf{l}^{\mathbf{M e}[5]}$ were prepared according to literature procedures.

\section{Condition A}

In a $30 \mathrm{~mL}$ stainless steel reactor, the epoxide $(1 \mathrm{mmol})$ was dissolved in MEK (3 $\mathrm{mL})$ and $\mathbf{A l}^{\mathrm{Cl}}$ (0.02 mmol, $2 \mathrm{~mol} \%, 12.8 \mathrm{mg}$ ) and TBAB (0.05 mmol $5 \mathrm{~mol} \%, 16.0 \mathrm{mg}$ ) were added. Three cycles of pressurization and depressurization of the reactor with 10 bar of $\mathrm{CO}_{2}$ were carried out before finally stabilizing at 10 bar. The mixture was stirred at 45 ${ }^{\circ} \mathrm{C}$ for $18 \mathrm{~h}$, then cooled in an ice bath and carefully depressurized. The solvent was removed in vacuo and the resulting product was purified by flash chromatography. Unless stated otherwise, the eluent was $10 \%$ - 25\% EA in hexane.

\section{Condition B}

In a stainless-steel HEL-multireactor, the epoxide $(0.5 \mathrm{mmol})$ was dissolved in MEK (400 $\mu \mathrm{L})$ and $\mathbf{A l}^{\mathrm{Me}}$ (0.01 mmol $2 \mathrm{~mol} \%, 5.1 \mathrm{mg}$ ) and TBAB (0.05 mmol $10 \mathrm{~mol} \%, 8.0$ mg) were added. The reactor was purged twice with $\mathrm{CO}_{2}(10 \mathrm{bar})$ and then charged with $\mathrm{CO}_{2}$ (10 bar). The mixture was stirred at $50{ }^{\circ} \mathrm{C}$ for $18 \mathrm{~h}$, then cooled in an ice bath and carefully depressurized. The solvent was removed in vacuo and the resulting product was purified by flash chromatography employing $10 \%$ - 25\% EA in hexane as eluent. 


\section{S7: Experimental procedure for the synthesis of 6-membered carbonates $2 \mathbf{a}-2 \mathbf{q}$}

The respective 5-membered cyclic carbonate ( $0.1 \mathrm{mmol})$, TBD (0.3 equiv, $0.03 \mathrm{mmol}$, $4.2 \mathrm{mg}$ ) and 1-acetylimidazole (AcIm, 1.2 equiv, $0.12 \mathrm{mmol}, 13.2 \mathrm{mg}$ ) were added in an oven-dried glassware glass vial under argon, and then $0.2 \mathrm{~mL}$ of $\mathrm{CH}_{3} \mathrm{CN}$ was added via a syringe. The reaction mixture was stirred at room temperature. After $2 \mathrm{~h}$, the mixture was transferred to a round-bottom flask, concentrated and purified by flash column chromatography with 10-25 \% EA in hexane as eluent. In some cases, TLC plates were used to purify the product mixtures. 


\title{
S8: Experimental procedure for the synthesis of $1 \mathrm{~h}-\mathrm{Ac}$
}

\author{
$C f$., Scheme $4 \mathrm{~b}$ in the main text:
}

Cyclohexanone $(10 \mathrm{mmol})$ was added to a $50 \mathrm{~mL}$ oven-dried Schleck flask under nitrogen, and then $10 \mathrm{~mL}$ of dry THF was added via a syringe. Allylmagnesium bromide (12 mL, 1.2 equiv, $1.0 \mathrm{M} \mathrm{Et}_{2} \mathrm{O}$ solution) was added dropwise at $0{ }^{\circ} \mathrm{C}$ using an ice bath. The reaction mixture was stirred at room temperature for $16 \mathrm{~h}$, quenched with $\mathrm{Ac}_{2} \mathrm{O}$ (1.2 equiv, $12 \mathrm{mmol}, 1.23 \mathrm{~g}$ ). The mixture was stirred for another $2 \mathrm{~h}$, and then extracted with $\mathrm{Et}_{2} \mathrm{O}(3 \times 30 \mathrm{~mL})$. The combined organic layers were washed with brine, dried over $\mathrm{Na}_{2} \mathrm{SO}_{4}$, filtered, concentrated and purified by flash column chromatography using 1-5 \% EA in hexane as eluent. The first product A18 (the acetyl-protected homo-allylic alcohols) was isolated as a yellow liquid. Yield: 50\% (0.91 g).

The following epoxidation and cycloaddition reactions were similar to the procedures described under Method A (page S3) and Condition A (page S6). The epoxide intermediate B18 (scale: $5 \mathrm{mmol}$ ) was isolated as a light yellow oil. Yield: 13\%, 130.2 mg.

The final product $\mathbf{1 h}$-Ac (scale: $0.5 \mathrm{mmol}$ ) was isolated as an orange oil. Yield: $77 \%$, $92.8 \mathrm{mg}$. 
S9: Qualitative reactions between $\mathrm{Al}^{\mathrm{Cl}}$ and epoxy alcohol B1

\begin{tabular}{|c|c|c|c|c|c|c|}
\hline Entry $^{[\mathrm{la}}$ & Cat. & DBU & $\mathrm{CO}_{2}$ & AcIm & Conv. & $1 a / 3 a$ \\
\hline 1 & $\checkmark$ & $\checkmark$ & $\checkmark$ & $\checkmark$ & High & $1 a+3 a$ \\
\hline 2 & $\checkmark$ & $x$ & $\checkmark$ & $\checkmark$ & High & $1 \mathrm{a}$ \\
\hline 3 & $x$ & $\checkmark$ & $\checkmark$ & $\checkmark$ & Low & $1 a+3 a$ \\
\hline 4 & $\checkmark$ & $\checkmark$ & $x$ & $\checkmark$ & 0 & - \\
\hline $5^{[\mathrm{b}]}$ & $x$ & $\checkmark$ & $x$ & $x$ & Low & $3 a$ \\
\hline
\end{tabular}




\section{S10: Characterization data for all new and relevant compounds \\ Homoallylic alcohols:}

Note: See reference ${ }^{[6]}$. The product was isolated as colorless oil, eluent: $1 \%-2 \%$ EA in hexane. Yield: 27\%, 95:5 dr.

${ }^{1}$ H NMR (400 MHz, $\mathbf{C D C l}_{3}$ ) $\delta 7.58$ (dd, $\left.J=7.3,1.9 \mathrm{~Hz}, 2 \mathrm{H}\right), 7.47-7.34$ (m, 3H), 5.63 - 5.49 (m, 1H), 5.32 - 5.17 (m, 2H), 2.99 (dd, $J=14.3,6.7$ Hz, 1H), 2.85 (dd, $J=14.2$, 8.1 Hz, 1H), 2.61 (s, 1H) ppm; ${ }^{13} \mathbf{C}$ NMR (101 MHz, $\left.\mathbf{C D C l}_{3}\right) \delta$ 136.98, 130.53, 129.70, 128.69, 128.49, 128.37, 126.87, 126.59, 126.58, 124.03, 122.16, 76.06, 75.78, 75.50, 40.46 ppm; ${ }^{19}$ F NMR (376 MHz, $\mathbf{C D C l}_{3}$ ) $\delta$-78.91, -79.16 ppm.

Note: See reference ${ }^{[7]}$. The product was isolated as a light yellow solid, eluent: $2 \%$ 3\% EA in hexane, yield: $37 \%$.

${ }^{1}$ H NMR (500 MHz, $\mathbf{C D C l}_{3}$ ) $\delta 7.24-7.13$ (m, 4H), 6.13 - 5.89 (m, 1H), 5.26 - 5.16 (m, 2H), 3.57 (s, 1H), 3.09 (d, $J=16.2 \mathrm{~Hz}, 2 \mathrm{H}), 2.96$ (d, $J=16.2 \mathrm{~Hz}, 2 \mathrm{H}), 2.52$ (dt, $J=$ 7.3, $1.2 \mathrm{~Hz}, 2 \mathrm{H}) \mathrm{ppm} ;{ }^{13} \mathbf{C}$ NMR (126 MHz, $\left.\mathbf{C D C l}_{3}\right) \delta$ 141.30, 134.10, 126.76, 125.12, 119.18, 81.61, 46.64, 45.16 ppm.

The product was isolated as light yellow oil, eluent: 2\%-3\% EA in hexane. Yield: 50\%. ${ }^{1}$ H NMR (400 MHz, $\mathbf{C D C l}_{3}$ ) $\delta 5.85$ - 5.66 (m, 1H), $5.11-4.93$ (m, 2H), 2.64 (dt, $J=$ 7.4, $1.2 \mathrm{~Hz}, 2 \mathrm{H}), 2.25$ - 2.11 (m, 2H), 2.00 (s, 3H), 1.66 - 1.30 (m, 8H) ppm; ${ }^{13} \mathbf{C}$ NMR (101 MHz, $\left.\mathbf{C D C l}_{3}\right) \delta$ 170.52, 133.25, 118.15, 83.45, 42.07, 34.60, 25.63, 22.38, 21.94 ppm; HRMS (ESI+; MeOH): m/z calcd. $\left(\mathrm{C}_{11} \mathrm{H}_{18} \mathrm{O}_{2}\right) 123.1168\left(\mathrm{M}-\mathrm{CH}_{3} \mathrm{COO}\right)^{+}$: found: 123.1169. 


\section{Expoxy alcohols B1-B18:}

The product was isolated as a white solid, yield: $98 \%$.

${ }^{1} \mathbf{H}$ NMR (400 MHz, $\mathbf{C D C l}_{3}$ ) $\delta 7.50$ - 7.42 (m, 4H), 7.36 - 7.22 (m, 6H), $3.21(\mathrm{~s}, 1 \mathrm{H})$, 2.98 (dtd, $J=7.0,4.2,2.7 \mathrm{~Hz}, 1 \mathrm{H}), 2.78-2.64$ (m, 2H), 2.47 (dd, $J=4.9,2.8 \mathrm{~Hz}, 1 \mathrm{H}$ ), 2.35 (dd, $J=14.4,7.2 \mathrm{~Hz}, 1 \mathrm{H}$ ) ppm; ${ }^{13} \mathbf{C}$ NMR (126 MHz, $\mathbf{C D C l}_{3}$ ) $\delta$ 146.91, 146.27, 128.43, 128.42, 127.31, 127.14, 126.16, 125.95, 78.24, 49.80, 47.18, 44.27 ppm; HRMS (ESI+; MeOH): $m / z$ calcd. $\left(\mathrm{C}_{16} \mathrm{H}_{16} \mathrm{NaO}_{2}\right) 236.1043(\mathrm{M}+\mathrm{Na})^{+}$: found: 263.1046.

The product was isolated as an orange oil, yield: $56 \%$.

${ }^{1}$ H NMR (400 MHz, $\left.\mathbf{C D C l}_{3}\right) \delta 7.39$ - 7.29 (m, 4H), 6.89 - 6.81 (m, 4H), 3.80 (s, 3H), 3.78 (s, 3H), 3.08 (s, 1H), 2.97 (dtd, $J=7.1,4.3,2.8 \mathrm{~Hz}, 1 \mathrm{H}$ ), 2.68 (dd, $J=4.9,4.0 \mathrm{~Hz}$, 1H), 2.61 (dd, $J=14.3,4.4 \mathrm{~Hz}, 1 \mathrm{H}$ ), 2.45 (dd, $J=4.9,2.8 \mathrm{~Hz}, 1 \mathrm{H}$ ), 2.34 (dd, $J=14.3$, 7.0 Hz, 1H) ppm; ${ }^{13} \mathbf{C}$ NMR (101 MHz, $\left.\mathbf{C D C l}_{3}\right) \delta$ 158.68, 158.58, 139.46, 138.73, 127.37, 127.23, 113.65, 113.63, 77.68, 55.37, 49.85, 47.23, 44.59 ppm; HRMS (ESI+; MeOH): $m / z$ calcd. $\left(\mathrm{C}_{18} \mathrm{H}_{20} \mathrm{NaO}_{4}\right)$ 323.1254; $(\mathrm{M}+\mathrm{Na})^{+}$: found: 323.1246 .

The product was isolated as a pale-colored oil, eluent: 5\%-10\% EA in hexane, yield: $73 \%$.

${ }^{1}$ H NMR (400 MHz, CDCl $)_{3} \delta 7.38$ - 7.29 (m, 4H), 7.18 - 7.10 (m, 4H), $3.11(\mathrm{~s}, 1 \mathrm{H})$, 2.98 (dtd, $J=7.0,4.2,2.7 \mathrm{~Hz}, 1 \mathrm{H}), 2.70-2.62$ (m, 2H), 2.45 (dd, $J=4.9,2.8 \mathrm{~Hz}, 1 \mathrm{H}$ ), 2.40 - 2.30 (m, 7H) ppm; ${ }^{13}$ C NMR (101 MHz, $\left.\mathbf{C D C l}_{3}\right) \delta$ 144.18, 143.58, 136.78, 
136.61, 129.04, 129.02, 126.02, 125.83, 77.91, 49.82, 47.19, 44.36, 21.09; HRMS (ESI+; MeOH): $\mathrm{m} / \mathrm{z}$ calcd. $\left(\mathrm{C}_{18} \mathrm{H}_{20} \mathrm{NaO}_{2}\right) 291.1356(\mathrm{M}+\mathrm{Na})^{+}$: found: 291.1358. 
The product was isolated as a white solid, yield: $83 \%$.

${ }^{1}$ H NMR (400 MHz, CDCl $) \delta 7.44-7.38$ (m, 2H), 7.36 - $7.26(\mathrm{~m}, 6 \mathrm{H}), 3.47$ (s, 1H), 2.94 (dtd, $J=7.8,3.9,2.7 \mathrm{~Hz}, 1 \mathrm{H}), 2.77-2.69$ (m, 2H), 2.49 (dd, $J=4.8,2.8 \mathrm{~Hz}, 1 \mathrm{H}$ ), 2.20 (dd, $J=14.5,7.7 \mathrm{~Hz}, 1 \mathrm{H})$ ppm; ${ }^{13} \mathbf{C}$ NMR (101 MHz, $\mathbf{C D C l}_{3}$ ) $\delta$ 145.06, 144.36, 133.38, 133.27, 128.69, 128.61, 127.59, 127.32, 77.67, 49.58, 47.08, 43.87 ppm; HRMS (ESI+; MeOH): $\mathrm{m} / \mathrm{z}$ calcd. $\left(\mathrm{C}_{16} \mathrm{H}_{14} \mathrm{Cl}_{2} \mathrm{NaO}_{2}\right) 331.0263(\mathrm{M}+\mathrm{Na})^{+}$: found: 331.0258 .

The product was isolated as a white solid, yield: $79 \%$.

${ }^{1}$ H NMR (500 MHz, $\mathbf{C D C l}_{3}$ ) $\delta 7.46$ - 7.41 (m, 2H), 7.39 - 7.34 (m, 2H), 7.07 - 6.94 (m, 4H), 3.43 (s, 1H), 2.95 (dtd, $J=7.8,4.0,2.7 \mathrm{~Hz}, 1 \mathrm{H}), 2.74-2.66$ (m, 2H), 2.48 (dd, $J=4.8,2.8 \mathrm{~Hz}, 1 \mathrm{H}), 2.25$ (dd, $J=14.4,7.5 \mathrm{~Hz}, 1 \mathrm{H}) \mathrm{ppm} ;{ }^{13} \mathbf{C}$ NMR (126 MHz, $\mathbf{C D C l}_{3}$ ) $\delta$ 162.98, 162.93, 161.02, 160.97, 142.66, 142.63, 141.87, 141.85, 127.91, 127.85, 127.72, 127.66, 115.36, 115.28, 115.19, 115.11, 77.64, 49.65, 47.09, 44.32 ppm; ${ }^{19} \mathbf{F}$ NMR (376 MHz, $\left.\mathbf{C D C l}_{3}\right) \delta$-115.55, -115.82 ppm; HRMS (ESI+; MeOH): m/z calcd. $\left(\mathrm{C}_{16} \mathrm{H}_{13} \mathrm{~F}_{2} \mathrm{O}\right) 259.0929(\mathrm{M}-\mathrm{OH})^{+}$: found: 259.0929.

The product was isolated as a light yellow oil, yield: 76\%.

${ }^{1} \mathbf{H}$ NMR (500 MHz, $\mathbf{C D C l}_{3}$ ) $\delta 3.10$ (dtd, $J=$ 7.0, 4.1, $\left.2.7 \mathrm{~Hz}, 1 \mathrm{H}\right), 2.78$ (dd, $J=5.1$, $4.0 \mathrm{~Hz}, 1 \mathrm{H}$ ), 2.47 (dd, $J=5.0,2.7 \mathrm{~Hz}, 1 \mathrm{H}), 1.79$ (dd, $J=14.5,4.2 \mathrm{~Hz}, 2 \mathrm{H}$ ), 1.59 - 1.46 (m, 5H), 1.40 - 1.26 (m, 4H), 0.93 (td, $J=7.3,2.6$ Hz, 6H) ppm; ${ }^{13}$ C NMR (126 MHz, $\left.\mathbf{C D C l}_{3}\right) \delta$ 74.63, 49.24, 46.99, 42.15, 42.11, 42.03, 17.05, 16.94, 14.80, 14.77 ppm; HRMS (ESI+; MeOH): m/z calcd. $\left(\mathrm{C}_{10} \mathrm{H}_{19} \mathrm{O}\right) 155.1430(\mathrm{M}-\mathrm{OH})^{+}$: found: 155.1428. 
The product was isolated as a colorless oil, yield: $83 \%$.

${ }^{1}$ H NMR (500 MHz, $\mathbf{C D C l}_{3}$ ) $\delta 3.04$ (dtd, $J=$ 7.0, 4.2, $2.7 \mathrm{~Hz}, 1 \mathrm{H}$ ), 2.80 (dd, $J=5.1$, $4.0 \mathrm{~Hz}, 1 \mathrm{H}), 2.49$ (dd, $J=5.0,2.8 \mathrm{~Hz}, 1 \mathrm{H}), 1.89-1.72$ (m, 10H), $1.64-1.52$ (m, 4H), 1.33 - 0.95 (m, 10H) ppm; ${ }^{13} \mathbf{C}$ NMR (126 MHz, $\left.\mathbf{C D C l}_{3}\right) \delta$ 77.37, 49.61, 48.10, 45.29, 44.91, 37.15, 27.58, 27.39, 27.32, 27.22, 27.18, 27.16, 27.12, 27.09, 26.81 ppm; HRMS (ESI+; MeOH): m/z calcd. $\left(\mathrm{C}_{16} \mathrm{H}_{27} \mathrm{O}\right) 235.2056(\mathrm{M}-\mathrm{OH})^{+}$: found: 235.2057.

The product was isolated as a light yellow oil, yield: $86 \%{ }^{[1]}$

${ }^{1}$ H NMR (400 MHz, $\mathbf{C D C l}_{3}$ ) $\delta 3.15$ (dtd, $J=$ 7.1, 4.2, $2.8 \mathrm{~Hz}, 1 \mathrm{H}$ ), 2.79 (dd, $J=5.0$, 4.0 Hz, 1H), 2.47 (dd, $J=5.0,2.7 \mathrm{~Hz}, 1 \mathrm{H}$ ), 1.80 (dd, $J=14.4,4.3 \mathrm{~Hz}, 2 \mathrm{H}$ ), $1.70-1.41$ (m, 11H) ppm; ${ }^{13} \mathbf{C}$ NMR (101 MHz, $\mathbf{C D C l}_{3}$ ) $\delta$ 71.70, 49.05, 46.93, 44.67, 38.13, 37.84, 25.78, 22.30, $22.21 \mathrm{ppm}$.

The product was isolated as a colorless oil, yield: 59\%.

${ }^{1}$ H NMR (400 MHz, $\left.\mathbf{C D C l}_{3}\right) \delta 3.21-3.11$ (m, 1H), 2.80 (t, $\left.J=4.5 \mathrm{~Hz}, 1 \mathrm{H}\right), 2.48$ (dd, $J$ $=5.1,2.8 \mathrm{~Hz}, 1 \mathrm{H}), 1.95-1.77(\mathrm{~m}, 4 \mathrm{H}), 1.71-1.37$ (m, 14H) ppm; ${ }^{13} \mathbf{C}$ NMR (101 MHz, $\left.\mathbf{C D C l}_{3}\right) \delta$ 75.22, 49.25, 47.03, 44.04, 36.79, 36.68, 28.35, 28.28, 25.06, 22.34, 22.30 ppm. HRMS (ESI+; MeOH): m/z calcd. $\left(\mathrm{C}_{11} \mathrm{H}_{20} \mathrm{NaO}_{2}\right) 207.1356(\mathrm{M}+\mathrm{Na})^{+}$: found: 207.1357. 
The product was isolated as a light yellow oil, yield: 89\%, 63:37 $d r$.

${ }^{1}$ H NMR (500 MHz, $\mathbf{C D C l}_{3}$ ) $\delta 7.43$ - 7.34 (m, 5.57H), 7.22 - 7.11 (m, 5.51H), 3.00 2.95 (m, 1H), 2.87 (dtd, $J=8.1,3.8,2.8 \mathrm{~Hz}, 1.73 \mathrm{H}$ ), 2.77 (s, 1.29H), 2.72 (dd, $J=5.0$, $4.0 \mathrm{~Hz}, 1.09 \mathrm{H}$ ), 2.66 (dd, $J=4.9,4.1 \mathrm{~Hz}, 1.76 \mathrm{H}$ ), 2.44 (dd, $J=5.0,2.7 \mathrm{~Hz}, 1.09 \mathrm{H}$ ), 2.41 (dd, $J=4.9,2.7 \mathrm{~Hz}, 1.99 \mathrm{H}$ ), 2.35 (s, 8.26H), 2.29 (dd, $J=14.5,3.5 \mathrm{~Hz}, 1.82 \mathrm{H}$ ), 2.07 (dd, $J=14.3,4.8 \mathrm{~Hz}, 1.09 \mathrm{H}$ ), 1.98 (dd, $J=14.3,6.7 \mathrm{~Hz}, 1.09 \mathrm{H}$ ), 1.75 (dd, $J=14.5,8.3$ $\mathrm{Hz}, 1.99 \mathrm{H}), 1.66$ (s, 3.43H), 1.59 (s, 5.74H) ppm; ${ }^{13} \mathbf{C}$ NMR (126 MHz, $\mathbf{C D C l}_{3}$ ) $\delta$ 144.77, 144.56, 136.64, 136.43, 129.13, 129.11, 124.77, 124.71, 74.81, 74.17, 49.72, 49.51, 47.07, 46.65, 46.42, 46.18, 31.02, 29.87, 21.09, 21.07 ppm; HRMS (ESI+; MeOH): $m / z$ calcd. $\left(\mathrm{C}_{12} \mathrm{H}_{16} \mathrm{NaO}_{2}\right) 215.1043(\mathrm{M}+\mathrm{Na})^{+}$: found: 215.1047.

The product was isolated as a colorless oil, yield: 85\%, 69:31 $d r$.

${ }^{1}$ H NMR (400 MHz, $\mathbf{C D C l}_{3}$ ) $\delta 7.44$ (ddt, $\left.J=8.4,6.3,1.2 \mathrm{~Hz}, 2.87 \mathrm{H}\right), 7.36$ (td, $J=7.7$, $1.6 \mathrm{~Hz}, 2.86 \mathrm{H}), 7.28$ - 7.22 (m, 1.69H), 2.97 (tdd, J = 5.8, 4.0, 2.7 Hz, 0.45H), 2.87 (s, 0.93H), 2.81 (dddd, $J=8.5,4.1,3.4,2.8 \mathrm{~Hz}, 1 \mathrm{H}$ ), 2.71 (dd, J = 5.0, 4.0 Hz, 0.46H), 2.63 (dd, $J=4.9,4.1 \mathrm{~Hz}, 1.01 \mathrm{H}$ ), 2.45 (dd, $J=5.0,2.8 \mathrm{~Hz}, 0.46 \mathrm{H}$ ), 2.40 (dd, $J=4.9,2.8 \mathrm{~Hz}$, 1.01H), 2.34 (d, $J=3.3 \mathrm{~Hz}, 0.91 \mathrm{H}$ ), 2.30 (d, J = 3.4 Hz, 0.53H), 2.06 (d, $J=5.7 \mathrm{~Hz}$, 0.86H), 1.97 (qd, $J=7.4,1.1 \mathrm{~Hz}, 0.86 \mathrm{H}$ ), 1.87 (qd, $J=7.4,2.4 \mathrm{~Hz}, 1.95 \mathrm{H}$ ), 1.76 (dd, $J$ $=14.5,8.4 \mathrm{~Hz}, 0.98 \mathrm{H}), 0.78(\mathrm{td}, J=7.4,1.8 \mathrm{~Hz}, 4.47 \mathrm{H}) \mathrm{ppm} ;{ }^{13} \mathrm{C}$ NMR (101 MHz, $\left.\mathbf{C D C l}_{3}\right) \delta$ 145.67, 128.35, 126.84, 126.69, 125.49, 125.33, 76.76, 49.71, 49.37, 47.27, 46.73, 44.98, 44.72, 36.20, 34.94, 7.79, 7.65 ppm; HRMS (ESI+; MeOH): m/z calcd. $\left(\mathrm{C}_{12} \mathrm{H}_{15} \mathrm{O}\right) 175.1117(\mathrm{M}-\mathrm{OH})^{+}$: found: 175.1115. 
Scale: 1.85 mmol. The product was isolated as white solid, eluent: 3\%-10\% EA in hexane. Yield: 42\%, 97:3 dr.

${ }^{1}$ H NMR (500 MHz, $\left.\mathbf{C D C l}_{3}\right) \delta 7.71-7.63$ (m, 2H), $7.49-7.34$ (m, 3H), $3.78(\mathrm{~s}, 1 \mathrm{H})$ ), $2.87-2.77$ (m, 2H), 2.70 (dd, $J=4.7,3.9 \mathrm{~Hz}, 1 \mathrm{H}$ ), 2.51 (dd, $J=4.6,2.6 \mathrm{~Hz}, 1 \mathrm{H}$ ), 1.92 (dd, $J=15.3,9.4 \mathrm{~Hz}, 1 \mathrm{H}) \mathrm{ppm} ;{ }^{13} \mathbf{C}$ NMR (126 $\left.\mathbf{M H z}, \mathbf{C D C l}_{3}\right) \delta 136.55,128.87,128.65$, 128.56, 126.80, 126.18, 123.91, 121.64, 48.56, 46.40, 37.77 ppm; ${ }^{19}$ F NMR (376 MHz, $\left.\mathbf{C D C l}_{3}\right) \delta$-78.45, -80.95; HRMS (ESI+; $\mathbf{M e O H ) : ~} \mathrm{m} / \mathrm{z}$ calcd. $\left(\mathrm{C}_{11} \mathrm{H}_{11} \mathrm{~F}_{3} \mathrm{NaO}_{2}\right) 255.0603$ $(\mathrm{M}+\mathrm{Na})^{+}$: found: 255.0605 .

The product was isolated as a yellow oil. Yield: 63\%, 57:43 $d r$.

${ }^{1}$ H NMR (400 MHz, $\left.\mathbf{C D C l}_{3}\right) \delta 7.48$ (d, $\left.J=8.0 \mathrm{~Hz}, 0.43 \mathrm{H}\right), 7.41-7.32$ (m, 0.57H), $7.04-6.92$ (m, 2H), $3.01-2.85$ (m, 0.99H), $2.77-2.67$ (m, 1.46H), $2.56-2.50$ (m, 3.50), 2.45 (td, $J=4.8,2.8 \mathrm{~Hz}, 1.04 \mathrm{H}$ ), $2.30-2.28$ (m, 3.59H), 2.21 (dd, $J=14.4,4.7$ $\mathrm{Hz}, 0.62 \mathrm{H}), 2.08$ (dd, $J=14.4,6.7 \mathrm{~Hz}, 0.56 \mathrm{H}), 1.80-1.72$ (m, 2.20H), 1.66 (s, 1.28H) ppm; ${ }^{13}$ C NMR (101 MHz, $\left.\mathbf{C D C l}_{3}\right) \delta$ 141.80, 141.56, 136.90, 136.74, 135.41, 134.52, 133.72, 133.58, 126.76, 126.52, 126.22, 126.04, 75.80, 75.39, 49.91, 49.66, 47.00, 46.71, 44.40, 29.78, 29.67, 22.47, 22.38, 20.80 ppm; HRMS (ESI+; MeOH): m/z calcd. $\left(\mathrm{C}_{13} \mathrm{H}_{17} \mathrm{O}\right) 189.1274(\mathrm{M}-\mathrm{OH})^{+}$: found: 189.1279 .

The product was isolated as a brown oil. Yield: 42\%, 74:26 $d r$.

${ }^{1}$ H NMR (400 MHz, CDCl$_{3}$ ) $\delta 8.08$ - 7.79 (m, 6.35H), 7.64 - 7.43 (m, 4.94H), 3.10 (s, 0.95H), 3.00 (dddd, $J=6.7,4.9,3.1,2.0 \mathrm{~Hz}, 1 \mathrm{H}$ ), 2.87 (dddd, $J=8.3,4.1,3.5,2.8 \mathrm{~Hz}$, 
0.35H), 2.72 (dd, $J=4.9,4.0 \mathrm{~Hz}, 0.62 \mathrm{H}$ ), 2.64 (dd, $J=4.9,4.1 \mathrm{~Hz}, 1.15 \mathrm{H}$ ), $2.45-2.39$ (m, 2.16H), 2.18 (dd, $J=14.4,4.9 \mathrm{~Hz}, 0.36 \mathrm{H}$ ), 2.09 (dd, $J=14.3,6.7 \mathrm{~Hz}, 0.38 \mathrm{H}$ ), 1.84 (dd, $J=14.5,8.3 \mathrm{~Hz}, 1.1 \mathrm{H}), 1.77$ (s, $1.08 \mathrm{H}), 1.69$ (s, 3.11H) ppm; ${ }^{13}$ C NMR (101 MHz, $\left.\mathbf{C D C l}_{3}\right) \delta 145.03,144.79,133.40,133.31,132.52,132.44,128.43,128.34,128.20$, 128.18, 127.63, 127.61, 126.46, 126.30, 126.00, 125.94, 123.51, 123.49, 123.47, 123.23, 75.17, 74.47, 49.73, 49.52, 47.11, 46.63, 46.16, 45.94, 31.08, 29.85 ppm; HRMS (ESI+; MeOH): m/z calcd. $\left(\mathrm{C}_{15} \mathrm{H}_{15} \mathrm{O}\right) 211.1117(\mathrm{M}-\mathrm{OH})^{+}$: found: 211.1119.

The product was isolated as colorless oil, eluent: 3\%-10\% EA in hexane. Yield: 47\%, 58:42 dr.

${ }^{1}$ H NMR (400 MHz, $\mathbf{C D C l}_{3}$ ) $\delta 3.64$ (ddd, $J=$ 9.4, 5.6, $2.8 \mathrm{~Hz}, 1 \mathrm{H}$ ), 3.58 (ddd, $J=$ 9.7, 5.7, $2.7 \mathrm{~Hz}, 0.71 \mathrm{H}), 3.19-3.13(\mathrm{~m}, 0.73 \mathrm{H}), 3.10$ (dtd, $J=7.1,4.2,2.7 \mathrm{~Hz}, 0.91 \mathrm{H}), 2.82$ (dd, $J=4.9,4.0 \mathrm{~Hz}, 0.75 \mathrm{H}$ ), 2.78 (dd, $J=4.9,4.0 \mathrm{~Hz}, 0.98 \mathrm{H}$ ), 2.61 (dd, $J=4.9,2.8 \mathrm{~Hz}$, 0.7H), 2.49 (dd, $J=4.9,2.7 \mathrm{~Hz}, 1.01 \mathrm{H}$ ), 2.14 (s, 1.39H), 1.92 - 0.95 (m, 25.75H) ppm; ${ }^{13}$ C NMR (101 MHz, $\left.\mathbf{C D C l}_{3}\right) \delta$ 74.98, 73.48, 51.32, 50.74, 47.23, 46.70, 43.91, 43.81, 36.72, 36.10, 29.13, 28.99, 28.04, 28.03, 26.61, 26.59, 26.35, 26.23, 26.21 ppm; HRMS (ESI+; MeOH): $m / z$ calcd. $\left(\mathrm{C}_{10} \mathrm{H}_{19} \mathrm{O}_{2}\right) 171.1380(\mathrm{M}+\mathrm{H})^{+}$: found: 171.1379 .

Scale: $3.6 \mathrm{mmol}$. The product was isolated as a light yellow solid, eluent: $2 \%$ - 3\% EA in hexane. Yield: 64\%.

${ }^{1}$ H NMR (400 MHz, CDCl $\left.{ }_{3}\right) \delta 7.25$ - 7.15 (m, 4H), 3.24 (dtd, $\left.J=6.8,4.1,2.7 \mathrm{~Hz}, 1 \mathrm{H}\right)$, 3.16 (d, $J=16.2 \mathrm{~Hz}, 2 \mathrm{H}), 3.06$ (d, $J=16.2 \mathrm{~Hz}, 2 \mathrm{H}), 2.84$ (dd, $J=5.0,4.1 \mathrm{~Hz}, 1 \mathrm{H}), 2.55$ (dd, $J=5.0,2.7 \mathrm{~Hz}, 1 \mathrm{H}$ ), 2.14 (dd, $J=14.3,4.1 \mathrm{~Hz}, 1 \mathrm{H}$ ), 1.81 (dd, $J=14.3,7.5 \mathrm{~Hz}$, 1H) ppm; ${ }^{13} \mathbf{C}$ NMR (126 MHz, $\left.\mathbf{C D C l}_{3}\right) \delta$ 141.17, 140.94, 126.90, 126.85, 125.24, 125.17, 81.90, 49.69, 47.14, 47.13, 46.93, 42.76 ppm; HRMS (ESI+; MeOH): m/z calcd. $\left(\mathrm{C}_{12} \mathrm{H}_{13} \mathrm{O}\right) 173.0961(\mathrm{M}-\mathrm{OH})^{+}$: found: 173.0962 . 
The product was isolated as a light yellow oil. Yield: 66\%, 67:33 $d r$.

${ }^{1}$ H NMR (400 MHz, CDCl $)$ ) 8.67 - 7.51 (m, 18H), 7.50 - 7.41 (m, 6H), 7.38 - 7.31 (m, 3H), 3.04 (dddd, $J=6.8,4.8,4.0,2.7 \mathrm{~Hz}, 1 \mathrm{H}), 2.97-2.88$ (m, 2H), 2.76 (dd, $J=$ 5.0, $4.0 \mathrm{~Hz}, 1 \mathrm{H}$ ), 2.70 (dd, $J=4.9,4.1 \mathrm{~Hz}, 2 \mathrm{H}$ ), 2.49 (dd, $J=5.0,2.7 \mathrm{~Hz}, 1 \mathrm{H}$ ), 2.45 (dd, $J=4.9,2.8 \mathrm{~Hz}, 2 \mathrm{H}$ ), 2.37 (dd, $J=14.5,3.4 \mathrm{~Hz}, 2 \mathrm{H}$ ), 2.15 (dd, $J=14.4,4.8 \mathrm{~Hz}, 1 \mathrm{H}$ ), 2.02 (dd, $J=14.4,6.8 \mathrm{~Hz}, 1 \mathrm{H}$ ), 1.79 (dd, $J=14.5,8.4 \mathrm{~Hz}, 2 \mathrm{H}$ ), 1.72 (s, 3H), 1.65 (s, 6H) ppm; ${ }^{13}$ C NMR (101 MHz, $\left.\mathbf{C D C l}_{3}\right) \delta$ 146.76, 146.55, 140.88, 140.85, 139.95, 139.78, 128.93, 128.90, 127.40, 127.38, 127.18, 127.15, 125.36, 125.29, 74.94, 74.26, 49.74, 49.51, 47.12, 46.69, 46.34, 46.10, 31.06, 29.82 ppm; HRMS (ESI+; MeOH): $\mathrm{m} / \mathrm{z}$ calcd. $\left(\mathrm{C}_{17} \mathrm{H}_{17} \mathrm{O}\right) 237.1274(\mathrm{M}-\mathrm{OH})^{+}$: found: 237.1281 .

Scale: 5 mmol. The product was isolated as light yellow oil, eluent: 5\% EA in hexane. Yield: 13\%. See page $\mathbf{S} 8$ for details.

${ }^{1}$ H NMR (400 MHz, $\mathbf{C D C l}_{3}$ ) $\delta 2.97$ (dtd, $J=7.0,4.1,2.7 \mathrm{~Hz}, 1 \mathrm{H}$ ), 2.73 (dd, $J=5.1$, $4.0 \mathrm{~Hz}, 1 \mathrm{H}$ ), 2.42 (dd, $J=5.1,2.7 \mathrm{~Hz}, 1 \mathrm{H}$ ), 2.34 - 2.24 (m, 3H), 2.04 (s, 3H), 1.91 (dd, $J=14.7,7.3 \mathrm{~Hz}, 1 \mathrm{H}), 1.60-1.39$ (m, 7H), $1.33-1.20$ (m, 1H) ppm; ${ }^{13}$ C NMR (101 MHz, $\left.\mathbf{C D C l}_{3}\right) \delta$ 170.74, 83.09, 48.51, 46.34, 40.58, 35.14, 34.98, 25.52, 22.40, 21.89, 21.79 ppm; HRMS (ESI+; MeOH): m/z calcd. $\left(\mathrm{C}_{11} \mathrm{H}_{18} \mathrm{NaO}_{3}\right) 221.1148(\mathrm{M}+\mathrm{Na})^{+}$: found: 221.1142. 
Condition A. The product was isolated as a white solid. Yield: 85\%.

${ }^{1}$ H NMR (400 MHz, $\mathbf{C D C l}_{3}$ ) $\delta 7.41-7.27$ (m, 10H), 4.68 (dddd, $J=9.3$, 8.5, 7.6, 3.6 Hz, 1H), 4.30 (dd, $J=9.0,7.6 \mathrm{~Hz}, 1 \mathrm{H}$ ), 4.05 (t, $J=8.8 \mathrm{~Hz}, 1 \mathrm{H}$ ), 2.99 (dd, $J=13.7,3.6$ Hz, 1H), 2.73 (dd, $J=13.7,9.3 \mathrm{~Hz}, 1 \mathrm{H}), 2.34$ (s, 1H) ppm; ${ }^{13} \mathrm{C}$ NMR (101 MHz, $\left.\mathbf{C D C l}_{3}\right) \delta 155.00,145.99,145.10,128.78,128.70,127.93,127.72,125.80,125.79$, 76.83, 75.34, 71.01, 45.49 ppm. IR (neat): $v=1777 \mathrm{~cm}^{-1}$; HRMS (ESI+; MeOH): $\mathrm{m} / \mathrm{z}$ calcd. $\left(\mathrm{C}_{17} \mathrm{H}_{16} \mathrm{NaO}_{4}\right) 307.0941(\mathrm{M}+\mathrm{Na})^{+}$: found: 307.0941.

Condition A. The product was isolated as a light yellow solid. Yield: 99\%.

${ }^{1}$ H NMR (500 MHz, $\mathbf{C D C l}_{3}$ ) $\delta 7.24$ (dd, $J=13.1,8.8 \mathrm{~Hz}, 4 \mathrm{H}$ ), 6.84 (dd, $J=12.4$, 8.6 $\mathrm{Hz}, 4 \mathrm{H}), 4.64$ (qd, $J=8.4,3.3 \mathrm{~Hz}, 1 \mathrm{H}), 4.24$ (t, $J=8.1 \mathrm{~Hz}, 1 \mathrm{H}), 4.00$ (t, $J=8.7 \mathrm{~Hz}$, 1H), 3.77 (d, $J=6.3 \mathrm{~Hz}, 6 \mathrm{H}$ ), 2.88 (dd, $J=13.6,3.4 \mathrm{~Hz}, 1 \mathrm{H}$ ), 2.73 (s, 1H), 2.63 (dd, $J=$ 13.6, 9.4 Hz, 1H) ppm; ${ }^{13} \mathbf{C}$ NMR (126 MHz, $\left.\mathbf{C D C l}_{3}\right) \delta$ 159.22, 159.07, 154.97, 138.35, 137.47, 131.13, 129.42, 127.18, 127.12, 114.06, 114.01, 76.45, 75.41, 71.07, 55.45, 45.90 ppm; IR (neat): $v=1769 \mathrm{~cm}^{-1}$; HRMS (ESI+; MeOH): $\mathrm{m} / \mathrm{z}$ calcd. $\left(\mathrm{C}_{19} \mathrm{H}_{20} \mathrm{NaO}_{6}\right)$ 367.1152 (M+Na) ${ }^{+}$: found: 367.1146. 
Condition A. The product was isolated as a white solid. Yield: 95\%.

${ }^{1}$ H NMR (500 MHz, CDCl $) \delta 7.23-7.18$ (m, 4H), 7.12 (dd, $J=11.0,8.1 \mathrm{~Hz}, 4 \mathrm{H}$ ), 4.64 (dddd, $J=9.5,8.6,7.6,3.4 \mathrm{~Hz}, 1 \mathrm{H}$ ), 4.25 (dd, $J=9.1,7.6 \mathrm{~Hz}, 1 \mathrm{H}$ ), 4.02 (t, $J=8.8$ Hz, 1H), 2.92 (dd, $J=13.6,3.4 \mathrm{~Hz}, 1 \mathrm{H}$ ), 2.65 (dd, $J=13.7,9.5 \mathrm{~Hz}, 1 \mathrm{H}$ ), 2.37 (s, 1H), 2.31 (d, $J=6.6 \mathrm{~Hz}, 6 \mathrm{H})$ ppm; ${ }^{13} \mathbf{C}$ NMR (126 MHz, $\mathbf{C D C l}_{3}$ ) $\delta$ 155.02, 143.28, 142.33, 137.73, 137.44, 129.44, 129.38, 125.71, 76.71, 75.44, 71.09, 45.60, 21.10 ppm; IR (neat): $v=1786 \mathrm{~cm}^{-1}$; HRMS (ESI+; MeOH): $\mathrm{m} / \mathrm{z}$ calcd. $\left(\mathrm{C}_{19} \mathrm{H}_{20} \mathrm{NaO}_{4}\right) 335.1254$ $(\mathrm{M}+\mathrm{Na})^{+}$: found: 335.1265 .

Condition A. The product was isolated as a white solid. Yield: $87 \%$.

${ }^{1}$ H NMR (500 MHz, $\mathbf{C D C l}_{3}$ ) $\delta 7.34-7.26$ (m, 8H), 4.62 (tdd, $J=8.5,7.6,4.1 \mathrm{~Hz}, 1 \mathrm{H}$ ), 4.34 (dd, $J=9.0,7.6 \mathrm{~Hz}, 1 \mathrm{H}), 4.07$ (t, $J=8.7 \mathrm{~Hz}, 1 \mathrm{H}$ ), 2.90 (dd, $J=13.9,4.1 \mathrm{~Hz}, 1 \mathrm{H}$ ), 2.79 (s, 1H), 2.66 (dd, $J=13.9,8.6 \mathrm{~Hz}, 1 \mathrm{H}) \mathrm{ppm} ;{ }^{13} \mathbf{C}$ NMR (126 MHz, $\mathbf{C D C l}_{3}$ ) $\delta$ 154.83, 144.06, 143.27, 134.12, 133.91, 129.04, 128.97, 127.29, 127.22, 76.26, 74.94, 70.87, 45.36 ppm; IR (neat): $v=1776 \mathrm{~cm}^{-1}$; HRMS (ESI+; MeOH): $\mathrm{m} / \mathrm{z}$ calcd. $\left(\mathrm{C}_{17} \mathrm{H}_{14} \mathrm{Cl}_{2} \mathrm{NaO}_{4}\right) 375.0161(\mathrm{M}+\mathrm{Na})^{+}$: found: 375.0160 . 
Condition A. The product was isolated as a white solid. Yield: $85 \%$.

${ }^{1}$ H NMR (500 MHz, $\mathbf{C D C l}_{3}$ ) $\delta 7.33$ (tdd, $\left.J=9.1,5.2,2.1 \mathrm{~Hz}, 4 \mathrm{H}\right), 7.04$ (td, $J=8.7,7.5$ $\mathrm{Hz}, 4 \mathrm{H}$ ), 4.64 (tdd, $J=8.5,7.6,4.0 \mathrm{~Hz}, 1 \mathrm{H}), 4.34$ (dd, $J=9.0,7.6 \mathrm{~Hz}, 1 \mathrm{H}), 4.07$ (t, $J=$ 8.7 Hz, 1H), 2.92 (dd, $J=13.8,4.0 \mathrm{~Hz}, 1 \mathrm{H}$ ), 2.69 (dd, $J=13.8,8.7 \mathrm{~Hz}, 1 \mathrm{H}$ ), 2.54 (s, 1H) ppm; ${ }^{13} \mathbf{C}$ NMR (126 MHz, $\left.\mathbf{C D C l}_{3}\right) \delta$ 163.31, 163.22, 161.34, 161.25, 154.79, 141.63, 141.60, 140.79, 140.77, 127.76, 127.70, 127.66, 127.60, 115.87, 115.77, 115.70, 115.61, 77.41, 74.98, 70.88, 45.81 ppm; ${ }^{19} \mathbf{F}$ NMR (376 MHz, $\mathbf{C D C l}_{3}$ ) $\delta$-113.76, -114.32 ppm; IR (neat): $v=1772 \mathrm{~cm}^{-1}$; HRMS (ESI+; MeOH): $\mathrm{m} / \mathrm{z}$ calcd. $\left(\mathrm{C}_{17} \mathrm{H}_{14} \mathrm{~F}_{2} \mathrm{NaO}_{4}\right) 343.0752(\mathrm{M}+\mathrm{Na})^{+}$: found: 343.0756.

Condition A. The product was isolated as a light yellow oil. Yield: 82\%.

${ }^{1}$ H NMR (500 MHz, $\mathbf{C D C l}_{3}$ ) $\delta 4.97-4.92$ (m, 1H), 4.58 (dd, $\left.J=8.8,7.7 \mathrm{~Hz}, 1 \mathrm{H}\right), 4.14$ (t, $J=8.6 \mathrm{~Hz}, 1 \mathrm{H}), 2.05$ (dd, $J=14.5,6.1 \mathrm{~Hz}, 1 \mathrm{H}), 1.79$ (dd, $J=14.5,6.7 \mathrm{~Hz}, 1 \mathrm{H}$ ), 1.54 - 1.24 (m, 10H), 0.93 (td, $J=7.2,5.1 \mathrm{~Hz}, 6 \mathrm{H}) \mathrm{ppm} ;{ }^{13} \mathbf{C}$ NMR (126 MHz, $\left.\mathbf{C D C l}_{3}\right) \delta$ 155.20, 74.78, 73.62, 71.07, 43.06, 42.98, 41.26, 17.24, 16.72, 14.63, 14.61 ppm; IR (neat): $v=1775 \mathrm{~cm}^{-1}$; HRMS (ESI+; MeOH): m/z calcd. $\left(\mathrm{C}_{11} \mathrm{H}_{20} \mathrm{NaO}_{4}\right) 239.1254$ $(\mathrm{M}+\mathrm{Na})^{+}$: found: 239.1252. 
Condition A. The product was isolated as a white solid. Yield: $67 \%$.

${ }^{1}$ H NMR (400 MHz, $\mathbf{C D C l}_{3}$ ) $\delta 4.93$ (qd, $\left.J=8.0,4.7 \mathrm{~Hz}, 1 \mathrm{H}\right), 4.53(\mathrm{t}, J=8.3 \mathrm{~Hz}, 1 \mathrm{H})$, $4.13(\mathrm{t}, J=8.4 \mathrm{~Hz}, 1 \mathrm{H}), 2.06-1.89(\mathrm{~m}, 2 \mathrm{H}), 1.87-1.59$ (m, 11H), 1.44 (qt, $J=11.7$, $2.9 \mathrm{~Hz}, 2 \mathrm{H}), 1.23-0.90$ (m, 10H) ppm; $\left.{ }^{13} \mathbf{C} \mathbf{~ N M R ~ ( 1 0 1 ~ M H z , ~} \mathbf{C D C l}_{3}\right) \delta$ 155.28, 76.06, 76.00, 71.43, 46.35, 45.31, 37.21, 27.22, 27.05, 26.79, 26.72, 26.62, 26.52, 26.48 ppm; IR (neat): $v=1789 \mathrm{~cm}^{-1}$; HRMS (ESI+; MeOH): $\mathrm{m} / \mathrm{z}$ calcd. $\left(\mathrm{C}_{17} \mathrm{H}_{28} \mathrm{NaO}_{4}\right) 319.1880$ $(\mathrm{M}+\mathrm{Na})^{+}$: found: 319.1864 .

Condition A. The product was isolated as a light yellow solid. Yield: 87\%.

${ }^{1}$ H NMR (500 MHz, $\mathbf{C D C l}_{3}$ ) $\delta 4.99$ (tt, $\left.J=8.1,6.4 \mathrm{~Hz}, 1 \mathrm{H}\right), 4.58$ (dd, $J=8.8,7.7 \mathrm{~Hz}$, 1H), 4.14 (t, $J=8.6 \mathrm{~Hz}, 1 \mathrm{H}), 2.10$ (dd, $J=14.5,6.3 \mathrm{~Hz}, 1 \mathrm{H}), 1.80-1.74$ (m, 2H), 1.64 - 1.28 (m, 10H) ppm; ${ }^{13} \mathbf{C}$ NMR (126 MHz, $\left.\mathbf{C D C l}_{3}\right) \delta$ 155.30, 74.60, 71.01, 70.52, 45.49, 39.37, 36.96, 25.45, 22.14, 22.07 ppm; IR (neat): $v=1787 \mathrm{~cm}^{-1}$; HRMS (ESI+; MeOH): $m / z$ calcd. $\left(\mathrm{C}_{10} \mathrm{H}_{16} \mathrm{NaO}_{4}\right) 223.0941(\mathrm{M}+\mathrm{Na})^{+}$: found: 223.0941. 
Condition A. The product was isolated as a white solid. Yield: 93\%.

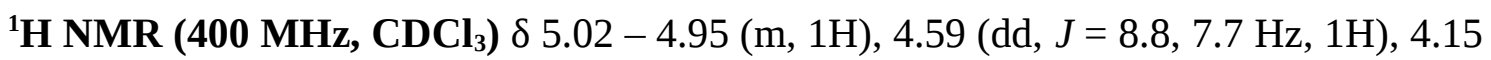
(t, $J=8.6 \mathrm{~Hz}, 1 \mathrm{H}), 2.15$ (dd, $J=14.5,6.2 \mathrm{~Hz}, 1 \mathrm{H}), 1.85-1.40(\mathrm{~m}, 16 \mathrm{H}) \mathrm{ppm} ;{ }^{13} \mathrm{C}$ NMR (126 MHz, $\mathbf{C D C l}_{3}$ ) $\delta$ 155.34, 74.89, 73.93, 71.05, 44.56, 38.49, 34.99, 28.16, 27.91, 24.96, 22.24, 22.05 ppm; IR (neat): $v=1776 \mathrm{~cm}^{-1}$; HRMS (ESI+; MeOH): $\mathrm{m} / \mathrm{z}$ calcd. $\left(\mathrm{C}_{12} \mathrm{H}_{20} \mathrm{NaO}_{4}\right) 251.1254(\mathrm{M}+\mathrm{Na})^{+}$: found: 251.1258.

Condition A. The product was isolated as a white solid. Yield: 79\%, 73:27 $d r$.

${ }^{1}$ H NMR (500 MHz, $\mathbf{C D C l}_{3}$ ) $\delta 7.32$ - 7.26 (m, 2.78H), 7.20 - 7.15 (m, 2.72H), 4.87 (tt, $J=8.1,6.4 \mathrm{~Hz}, 1 \mathrm{H}$ ), 4.47 (dd, $\mathrm{J}=8.7,7.5 \mathrm{~Hz}, 0.38 \mathrm{H}$ ), 4.38 (dddd, $\mathrm{J}=9.3$, 8.4, 7.5, 4.0 $\mathrm{Hz}, 0.37 \mathrm{H}), 4.25$ (t, J = 8.5 Hz, 0.38H), 4.21 (dd, $J=8.8,7.8 \mathrm{~Hz}, 1 \mathrm{H}), 3.79$ (t, $J=8.6$ $\mathrm{Hz}, 1 \mathrm{H}), 2.49-2.33$ (m, 5.75H), $2.22-2.10$ (m, 1.44H), 1.64 (s, 4.34H) ppm; ${ }^{13} \mathrm{C}$ NMR (126 MHz, $\left.\mathbf{C D C l}_{3}\right) \delta$ 155.13, 154.95, 143.80, 142.70, 137.25, 137.23, 129.47, 124.42, 124.32, 75.19, 74.81, 73.63, 73.17, 71.16, 70.35, 47.83, 47.29, 32.15, 30.72, 21.06 ppm; IR (neat): $v=1783 \mathrm{~cm}^{-1}$; HRMS (ESI+; MeOH): $m / z$ calcd. $\left(\mathrm{C}_{13} \mathrm{H}_{16} \mathrm{NaO}_{4}\right)$ $259.0941(\mathrm{M}+\mathrm{Na})^{+}$: found: 259.0952 . 
Condition B. The product was isolated as a pale yellow oil. Yield: 73\%, 7:3 $d r$.

${ }^{1}$ H NMR (500 MHz, $\mathbf{C D C l}_{3}$ ) $\delta 7.39$ - 7.32 (m, 5.68H), 7.29 - 7.25 (m, 1.42H), 4.82 (dddd, $J=8.3,7.7,6.8,5.8 \mathrm{~Hz}, 1 \mathrm{H}$ ), 4.48 (dd, $\mathrm{J}=8.5,7.2 \mathrm{~Hz}, 0.42 \mathrm{H}$ ), 4.36 (dddd, $\mathrm{J}=$ 9.5, 8.4, 7.1, 3.4 Hz, 0.42H), 4.30 (t, J = 8.5 Hz, 0.42H), 4.03 (dd, $J=8.8,7.7 \mathrm{~Hz}, 1 \mathrm{H}$ ), 3.67 (t, $J=8.6 \mathrm{~Hz}, 1 \mathrm{H}), 2.50-2.40$ (m, 1.42H), $2.37-2.10$ (m, 2.46H), $2.01-1.82$ (m, 2.94H), 0.74 (td, $J=7.4,1.5 \mathrm{~Hz}, 4.40 \mathrm{H}) \mathrm{ppm} ;{ }^{13} \mathbf{C}$ NMR (126 MHz, $\left.\mathbf{C D C l}_{3}\right) \delta 155.24$, 154.96, 144.38, 143.83, 128.71, 128.69, 127.32, 127.28, 125.02, 124.95, 76.16, 75.67, 75.28, 74.84, 71.34, 70.26, 46.77, 45.95, 36.47, 35.60, 7.46, 7.24 ppm; IR (neat): $v=$ $1776 \mathrm{~cm}^{-1}$; HRMS (ESI+; MeOH): $\mathrm{m} / \mathrm{z}$ calcd. $\left(\mathrm{C}_{13} \mathrm{H}_{16} \mathrm{NaO}_{4}\right) 259.0941(\mathrm{M}+\mathrm{Na})^{+}$: found: 259.0948 .

Condition B. Scale: $0.5 \mathrm{mmol}$. The product was isolated as white solid, eluent: $10 \%-$ 20\% EA in hexane. Yield: 78\%, 9:1 dr.

${ }^{1}$ H NMR (400 MHz, $\mathbf{C D C l}_{3}$ ) $\delta 7.57$ - 7.48 (m, 2H), $7.42-7.33$ (m, 3H), 4.73 (qd, $J=$ 7.5, $4.7 \mathrm{~Hz}, 1 \mathrm{H}$ ), 3.97 (ddd, $J=8.8,7.7,1.0 \mathrm{~Hz}, 1 \mathrm{H}$ ), 3.72 (td, $J=8.7,1.0 \mathrm{~Hz}, 1 \mathrm{H}$ ), 3.03 (s, 3H), 2.70 (ddd, $J=14.6,5.2,1.0 \mathrm{~Hz}, 1 \mathrm{H}$ ), 2.42 (dd, $J=14.6,7.3 \mathrm{~Hz}, 1 \mathrm{H}$ ) ppm; ${ }^{13} \mathrm{C}$ NMR (126 MHz, $\left.\mathbf{C D C l}_{3}\right) \delta$ 154.23, 135.57, 129.53, 129.12, 128.50, 126.15, 126.10, 123.87, 121.60, 76.35, 76.12, 73.35, 69.75, 39.95 ppm; ${ }^{19} \mathbf{F}$ NMR (376 MHz, $\mathbf{C D C l}_{3}$ ) $\delta$ -79.29, -80.21 ppm; IR (neat): $v=1786 \mathrm{~cm}^{-1}$; HRMS (ESI+; MeOH): $\mathrm{m} / \mathrm{z}$ calcd. $\left(\mathrm{C}_{12} \mathrm{H}_{13} \mathrm{~F}_{3} \mathrm{NaO}_{4}\right) 299.0502(\mathrm{M}+\mathrm{Na})^{+}$: found: 299.0491. 
Condition A. The product was isolated as a colorless oil. Yield: 46\%, 74:26 dr.

${ }^{1}$ H NMR (400 MHz, CDCl $\left.{ }_{3}\right) \delta 7.39$ - 7.34 (m, 1.35H), 7.06 - 6.90 (m, 2.75H), 4.93 (tt, $J=8.1,6.1 \mathrm{~Hz}, 1 \mathrm{H}), 4.46-4.35$ (m, 0.72H), 4.31 (dd, $J=8.8,7.7 \mathrm{~Hz}, 1 \mathrm{H}), 4.23-$ 4.18 (m, 0.35H), 3.91 (t, $J=8.7 \mathrm{~Hz}, 1.01 \mathrm{H}), 2.68$ (dd, J = 14.1, 3.8 Hz, 0.35H), 2.52 2.46 (m, $4.22 \mathrm{H}), 2.41-2.32$ (m, 2.02H), 2.30 (s, 4.17H), 2.25 - 2.12 (m, 1.14H), 1.72 1.70 (m, 4.26H) ppm; ${ }^{13} \mathbf{C}$ NMR (101 MHz, $\left.\mathbf{C D C l}_{3}\right) \delta$ 155.14, 155.03, 141.25, 139.80, 137.42, 137.41, 134.28, 134.26, 133.98, 133.86, 127.00, 126.92, 125.77, 125.54, 75.45, 75.07, 74.36, 74.04, 71.17, 70.52, 45.49, 45.12, 31.10, 29.67, 22.39, 22.34, 20.75 ppm; IR (neat): $v=1778 \mathrm{~cm}^{-1}$; HRMS (ESI+; MeOH): $\mathrm{m} / \mathrm{z}$ calcd. $\left(\mathrm{C}_{14} \mathrm{H}_{18} \mathrm{NaO}_{4}\right) 273.1097$ $(\mathrm{M}+\mathrm{Na})^{+}$: found: 273.1094 .

Condition A. The product was isolated as a pink solid employing $10 \%-70 \% \mathrm{Et}_{2} \mathrm{O}$ in hexane as eluent. Yield: 58\%, 9:1 $d r$.

${ }^{1}$ H NMR (500 MHz, $\mathbf{C D C l}_{3}$ ) $\delta 7.94-7.92$ (m, 0.99H), 7.86 - 7.83 (m, 3.37H), 7.54 7.43 (m, 3.79H), 4.88 (tt, $J=8.1,6.3 \mathrm{~Hz}, 1 \mathrm{H}), 4.48$ (dd, J = 8.7, 7.4 Hz, 0.10H), 4.42 4.33 (m, 0.08H), 4.28 (t, J = 8.5 Hz, 0.07H), 4.19 (dd, $J=8.8,7.8 \mathrm{~Hz}, 0.97 \mathrm{H}), 3.79$ (t, $J$ $=8.5 \mathrm{~Hz}, 1 \mathrm{H}), 2.68-2.55(\mathrm{~m}, 0.14 \mathrm{H}), 2.44(\mathrm{dd}, J=14.5,6.4 \mathrm{~Hz}, 1.04 \mathrm{H}), 2.24(\mathrm{dd}, J=$ 14.5, $6.2 \mathrm{~Hz}, 0.99 \mathrm{H}), 1.74$ (s, 3.43H) ppm; ${ }^{13} \mathbf{C}$ NMR (126 MHz, $\mathbf{C D C l}_{3}$ ) $\delta$ 155.05, 154.86, 144.01, 143.00, 133.28, 133.22, 132.61, 132.58, 128.79, 128.68, 128.30, 128.24, 127.72, 127.69, 126.70, 126.40, 126.25, 123.16, 123.06, 122.88, 122.84, 76.90, 75.08, 74.73, 73.88, 73.49, 71.11, 70.28, 47.57, 47.05, 32.10, 30.68 ppm; IR (neat): $v=$ $1782 \mathrm{~cm}^{-1}$; HRMS (ESI+; MeOH): $\mathrm{m} / \mathrm{z}$ calcd. $\left(\mathrm{C}_{16} \mathrm{H}_{16} \mathrm{NaO}_{4}\right) 295.0941(\mathrm{M}+\mathrm{Na})^{+}$: found: 295.1043. 
Condition A. The product was isolated as light yellow solid, eluent: 10\%-25\% EA in hexane. Yield: 27\%, 58:42 dr.

${ }^{1}$ H NMR (400 MHz, CDCl $\left.{ }_{3}\right) \delta 4.99-4.91$ (m, 1H), 4.61 - 4.54 (m, 1.02H), 4.25 - 4.21 (m, 0.42H), 4.15 (dd, $J=8.7,7.7 \mathrm{~Hz}, 0.58 \mathrm{H}), 3.63-3.59$ (m, 0.58H), $3.52-3.48$ (m, 0.42H), 2.06 - 1.63 (m, 8.64H), 1.40 - 0. 93 (m, 6.46H) ppm; ${ }^{13}$ C NMR (101 MHz, $\left.\mathbf{C D C l}_{3}\right) \delta$ 155.26, 75.93, 75.66, 72.57, 72.43, 70.61, 69.67, 44.29, 43.82, 38.29, 37.21, 28.93, 28.88, 27.99, 27.87, 26.42, 26.40, 26.16, 26.13, 26.04, 26.01 ppm; IR (neat): $v=$ $1791 \mathrm{~cm}^{-1}$; HRMS (ESI+; MeOH): $\mathrm{m} / \mathrm{z}$ calcd. $\left(\mathrm{C}_{11} \mathrm{H}_{18} \mathrm{NaO}_{4}\right) 237.1079(\mathrm{M}+\mathrm{Na})^{+}$: found: 237.1089.

The product was isolated as light yellow solid, eluent: 5\%-15\% EA in hexane. Yield: 50\%, 69:31 dr.

${ }^{1}$ H NMR (400 MHz, $\mathbf{C D C l}_{3}$ ) $\delta 4.94-4.89$ (ddd, $J=9.7,5.5,3.0 \mathrm{~Hz}, 0.31 \mathrm{H}$ ), 4.78 $4.66(\mathrm{~m}, 1.69 \mathrm{H}), 4.58-4.48(\mathrm{~m}, 1.02 \mathrm{H}), 4.13-4.06(\mathrm{~m}, 1.02 \mathrm{H}), 2.21-2.10(\mathrm{~m}$, 0.98H), 2.08 - 2.07 (m, 3.12H), 1.93 - 1.84 (m, 1.15H), 1.78 - 1.66 (m, 5.32H), 1.57 1.48 (m, 1.14H), 1.27 - 1.10 (m, 3.80H), 1.05 - 0.93 (m, 2.24H) ppm; ${ }^{13}$ C NMR (101 MHz, $\left.\mathbf{C D C l}_{3}\right) \delta 171.27,170.62,154.85,154.65,74.85,74.82,74.35,73.65,69.69$, 69.58, 41.80, 41.58, 36.03, 35.87, 28.97, 28.62, 28.26, 28.11, 26.35, 26.28, 26.05, 25.96, 25.90, 21.18, 21.12 ppm; IR (neat): $v=1729,1798 \mathrm{~cm}^{-1}$; HRMS (ESI+; MeOH): $m / z$ calcd. $\left(\mathrm{C}_{13} \mathrm{H}_{20} \mathrm{NaO}_{5}\right) 279.1210(\mathrm{M}+\mathrm{Na})^{+}$: found: 279.1203. 
Condition B. The product was isolated as a colorless oil. Yield: 58\%.

${ }^{1}$ H NMR (500 MHz, $\mathbf{C D C l}_{3}$ ) $\delta 7.25$ - 7.17 (m, 4H), 5.06 (tt, $\left.J=8.0,6.4 \mathrm{~Hz}, 1 \mathrm{H}\right), 4.61$ (dd, $J=8.8,7.8 \mathrm{~Hz}, 1 \mathrm{H}), 4.20$ (t, $J=8.5 \mathrm{~Hz}, 1 \mathrm{H}), 3.21-2.93$ (m, 4H), $2.28-2.18$ (m, 3H) ppm; ${ }^{13} \mathbf{C}$ NMR (126 MHz, $\mathbf{C D C l}_{3}$ ) $\delta$ 155.19, 140.65, 140.05, 127.16, 127.12, 125.43, 125.27, 80.54, 75.08, 70.68, 48.34, 46.67, 43.66 ppm; IR (neat): $v=1779 \mathrm{~cm}^{-1}$; HRMS (ESI+; MeOH): m/z calcd. $\left(\mathrm{C}_{13} \mathrm{H}_{14} \mathrm{NaO}_{4}\right) 257.0784(\mathrm{M}+\mathrm{Na})^{+}$: found: 257.0792.

Condition A. The product was isolated as a white solid. Yield: 41\%, 83:17 $d r$.

${ }^{1}$ H NMR (400 MHz, $\mathbf{C D C l}_{3}$ ) $\delta 7.63$ - 7.57 (m, 4.06H), 7.51 - 7.43 (m, 4.11H), 7.40 7.34 (m, 1.07H), 4.92 (tt, $J=8.0,6.3 \mathrm{~Hz}, 0.83 \mathrm{H}), 4.54-4.41$ (m, 0.37H), $4.31-4.24$ (m, 1H), 3.85 (t, $J=8.6 \mathrm{~Hz}, 0.84 \mathrm{H}), 2.58-2.28$ (m, 1.93H), $2.27-2.13(\mathrm{~m}, 1.23 \mathrm{H})$, 1.68 (s, 3.12H) ppm; ${ }^{13}$ C NMR (101 MHz, $\left.\mathbf{C D C l}_{3}\right) \delta$ 155.18, 155.02, 145.85, 144.72, $140.41,140.29$, 128.95, 128.90, 127.60, 127.57, 127.39, 127.36, 127.12, 127.10, 125.03, 124.93, 75.19, 74.81, 73.51, 73.13, 71.18, 70.36, 47.66, 47.23, 32.00, 30.50 ppm; IR (neat): $v=1768 \mathrm{~cm}^{-1}$; HRMS (ESI+; MeOH): $\mathrm{m} / \mathrm{z}$ calcd. $\left(\mathrm{C}_{18} \mathrm{H}_{18} \mathrm{NaO}_{4}\right)$ 321.1097 (M+Na) $)^{+}$: found: 321.1102. 
Note: this carbonate was separately prepared for the control experiment reported in Scheme 4b (see the main text and page S8 for details):

Condition A. Scale: $0.5 \mathrm{mmol}$. The product was isolated as orange oil, eluent: $10 \%-$ 25\% EA in hexane. Yield: 77\%.

${ }^{1}$ H NMR (400 MHz, $\mathbf{C D C l}_{3}$ ) $\delta 4.84$ (tdd, $\left.J=8.5,7.8,3.5 \mathrm{~Hz}, 1 \mathrm{H}\right), 4.52$ (dd, $J=8.5$, $7.8 \mathrm{~Hz}, 1 \mathrm{H}), 4.00$ (t, $J=8.4 \mathrm{~Hz}, 1 \mathrm{H}), 2.46-2.21$ (m, 4H), 2.05 (s, 3H), 1.64 - 1.26 (m, 8H) ppm; ${ }^{13} \mathbf{C}$ NMR (101 MHz, $\left.\mathbf{C D C l}_{3}\right) \delta$ 170.96, 154.90, 81.91, 73.74, 70.02, 41.87, 35.12, 34.95, 25.28, 22.37, 21.84, 21.61 ppm; IR (neat): $v=1725,1794 \mathrm{~cm}^{-1}$; HRMS (ESI+; MeOH): m/z calcd. $\left(\mathrm{C}_{12} \mathrm{H}_{18} \mathrm{NaO}_{5}\right) 265.1046(\mathrm{M}+\mathrm{Na})^{+}$: found: 265.1045.

Note: the following tetrahydrofuran derivative $3 \mathbf{0}$ was isolated in the synthesis of cyclic carbonate 10:

Condition A. The product was isolated as colorless oil, eluent: 10\%-25\% EA in hexane. Yield: $48 \%$.

${ }^{1}$ H NMR (400 MHz, $\mathbf{C D C l}_{3}$ ) $\delta 4.46$ - 4.38 (m, 1H), 3.92 (dd, $J=9.8,4.3 \mathrm{~Hz}, 0.52 \mathrm{H}$ ), $3.86-3.74(\mathrm{~m}, 1 \mathrm{H}), 3.70-3.58(\mathrm{~m}, 1 \mathrm{H}), 3.46$ (q, $J=7.7 \mathrm{~Hz}, 0.5 \mathrm{H}), 2.29-2.20$ (m, 1.44H), 1.98 - 1.87 (m, 1.62H), $1.81-0.87$ (m, 12.09H) ppm; ${ }^{13}$ C NMR (101 MHz, $\left.\mathbf{C D C l}_{3}\right) \delta 83.77,82.66,75.41,75.24,72.56,72.28,43.14,42.98,39.33,39.29,29.92$, 29.85, 29.22, 28.97, 26.58, 26.11, 26.06, 25.94, 25.88 ppm; HRMS (ESI+; MeOH): $\mathrm{m} / \mathrm{z}$ calcd. $\left(\mathrm{C}_{10} \mathrm{H}_{19} \mathrm{O}_{2}\right) 171.1380(\mathrm{M}+\mathrm{H})^{+}$: found: 171.1380 . 


\section{6-Membered Cyclic Carbonates 2a-2q:}

The product was isolated as a white solid. Yield: 91\%.

${ }^{1}$ H NMR (500 MHz, $\mathbf{C D C l}_{3}$ ) $\delta 7.42$ - 7.38 (m, 7H), 7.37 - 7.25 (m, 4H), $4.51-4.43$ (m, 1H), 4.28 (dd, $J=12.3,3.3 \mathrm{~Hz}, 1 \mathrm{H}$ ), $4.24-4.16$ (m, 1H), 2.93 (dd, $J=14.3$, 3.2 Hz, 1H), 2.58 (dd, $J=14.4,12.2 \mathrm{~Hz}, 1 \mathrm{H}), 2.08$ (s, 3H) ppm; ${ }^{13} \mathbf{C}$ NMR (126 MHz, CDCl $)$ $\delta$ 170.58, 148.12, 142.42, 141.07, 129.37, 128.76, 128.56, 128.55, 125.37, 125.20, 86.31, 74.10, 64.68, 34.21, 20.74 ppm; IR (neat): $v=1737 \mathrm{~cm}^{-1}$; HRMS (ESI+; MeOH): $m / z$ calcd. $\left(\mathrm{C}_{19} \mathrm{H}_{18} \mathrm{NaO}_{5}\right) 349.1046(\mathrm{M}+\mathrm{Na})^{+}$: found: 349.1039.

The product was isolated as a colorless oil. Yield: $83 \%$.

${ }^{1} \mathbf{H}$ NMR (500 MHz, CD $\mathbf{C N}$ ) $\boldsymbol{\delta} 7.33$ - 7.26 (m, 4H), 7.00 - 6.95 (m, 2H), 6.93 - 6.87 (m, 2H), 4.42 (ddt, $J=12.0,5.4,3.2 \mathrm{~Hz}, 1 \mathrm{H}$ ), 4.26 (dd, $J=12.4,3.0 \mathrm{~Hz}, 1 \mathrm{H}$ ), 4.16 (dd, $J=12.4,5.6 \mathrm{~Hz}, 1 \mathrm{H}), 3.79$ (s, 3H), 3.76 (s, 3H), 2.99 (dd, $J=14.5,3.4 \mathrm{~Hz}, 1 \mathrm{H}), 2.58$ (dd, $J=14.5,12.1 \mathrm{~Hz}, 1 \mathrm{H}), 2.03$ (s, 3H) ppm; ${ }^{13} \mathbf{C}$ NMR (126 MHz, CD $\left.{ }_{3} \mathbf{C N}\right) \delta 171.38$, 160.51, 160.45, 149.07, 136.42, 134.66, 127.88, 127.54, 115.33, 114.77, 87.02, 75.89, 65.50, 56.06, 56.00, 34.03, 20.87 ppm; IR (neat): $v=1742 \mathrm{~cm}^{-1}$; HRMS (ESI+; MeOH): $m / z$ calcd. $\left(\mathrm{C}_{21} \mathrm{H}_{23} \mathrm{O}_{7}\right) 387.1423(\mathrm{M}+\mathrm{H})^{+}$: found: 387.1438 . 
The product was isolated as a colorless oil. Yield: $82 \%$.

${ }^{1}$ H NMR (400 MHz, $\mathbf{C D C l}_{3}$ ) $\delta 7.26$ (dd, $J=$ 8.5, $\left.0.8 \mathrm{~Hz}, 4 \mathrm{H}\right), 7.23-7.17$ (m, 2H), 7.16 - 7.12 (m, 2H), 4.52 - 4.43 (m, 1H), 4.28 (dd, $J=12.3,3.3 \mathrm{~Hz}, 1 \mathrm{H}$ ), 4.20 (dd, $J=12.3$, $5.0 \mathrm{~Hz}, 1 \mathrm{H}$ ), 2.86 (dd, $J=14.3,3.2 \mathrm{~Hz}, 1 \mathrm{H}), 2.54$ (dd, $J=14.3,12.2 \mathrm{~Hz}, 1 \mathrm{H}$ ), 2.33 (d, $J$ $=10.8 \mathrm{~Hz}, 6 \mathrm{H}), 2.09$ (s, 3H) ppm; ${ }^{13} \mathbf{C}$ NMR (101 MHz, $\mathbf{C D C l}_{3}$ ) $\boldsymbol{\delta}$ 170.66, 148.33, 139.83, 138.45, 138.40, 138.33, 130.01, 129.40, 125.37, 125.14, 86.39, 77.48, 77.16, 76.84, 74.13, 64.80, 34.36, 21.13, 21.11, 20.80 ppm; IR (neat): $v=1741 \mathrm{~cm}^{-1}$; HRMS (ESI+; MeOH): $m / z$ calcd. $\left(\mathrm{C}_{21} \mathrm{H}_{22} \mathrm{NaO}_{5}\right) 377.1359(\mathrm{M}+\mathrm{Na})^{+}$: found: 377.1370.

The product was isolated as a colorless oil. Yield: $65 \%$.

${ }^{1}$ H NMR (500 MHz, CDCl $_{3}$ ) $\delta 7.43-7.38$ (m, 2H), $7.36-7.28$ (m, 6H), 4.46 (ddt, $J=$ 12.2, 4.9, $3.3 \mathrm{~Hz}, 1 \mathrm{H}$ ), 4.29 (dd, $J=12.4,3.4 \mathrm{~Hz}, 1 \mathrm{H}$ ), 4.22 (dd, $J=12.4,4.9 \mathrm{~Hz}, 1 \mathrm{H}$ ), 2.86 (dd, $J=14.4,3.2 \mathrm{~Hz}, 1 \mathrm{H}$ ), 2.54 (dd, $J=14.4,12.2 \mathrm{~Hz}, 1 \mathrm{H}), 2.10$ (s, 3H) ppm; ${ }^{13} \mathrm{C}$ NMR (126 MHz, $\left.\mathbf{C D C l}_{3}\right) \delta$ 170.60, 147.54, 140.60, 139.25, 135.08, 134.96, 129.80, 129.15, 126.80, 126.69, 85.46, 74.04, 64.56, 34.21, 20.80 ppm; IR (neat): $v=1738$ $\mathrm{cm}^{-1}$;

HRMS (ESI+; MeOH): $\mathrm{m} / \mathrm{z}$ calcd. $\left(\mathrm{C}_{19} \mathrm{H}_{16} \mathrm{Cl}_{2} \mathrm{NaO}_{5}\right) 417.0267(\mathrm{M}+\mathrm{Na})^{+}$: found: 417.0270. 
The product was isolated as a white solid. Yield: $84 \%$.

${ }^{1} \mathbf{H}$ NMR (500 MHz, $\left.\mathbf{C D C l}_{3}\right) \delta 7.39-7.31$ (m, 4H), 7.15 - 7.09 (m, 2H), $7.07-7.01$ (m, 2H), 4.47 (ddt, $J=12.2,4.9,3.3 \mathrm{~Hz}, 1 \mathrm{H}$ ), 4.30 (dd, $J=12.3,3.4 \mathrm{~Hz}, 1 \mathrm{H}$ ), 4.22 (dd, $J=12.4,4.9 \mathrm{~Hz}, 1 \mathrm{H}), 2.85$ (dd, $J=14.4,3.1 \mathrm{~Hz}, 1 \mathrm{H}), 2.56$ (dd, $J=14.4,12.2 \mathrm{~Hz}, 1 \mathrm{H})$, 2.10 (s, 3H) ppm; ${ }^{13} \mathbf{C}$ NMR (126 MHz, $\left.\mathbf{C D C l}_{3}\right) \delta$ 170.62, 163.68, 163.67, 161.70, 161.69, 147.74, 138.31, 138.28, 136.77, 136.75, 127.48, 127.41, 127.28, 127.21, 116.66, 116.49, 115.94, 115.77, 85.63, 74.07, 64.63, 34.56, 20.80 ppm; ${ }^{19}$ F NMR (376 MHz, $\mathbf{C D C l}_{3}$ ) $\delta-112.70,-112.85$ ppm; IR (neat): $v=1741 \mathrm{~cm}^{-1}$; HRMS (ESI+; MeOH): $\mathrm{m} / \mathrm{z}$ calcd. $\left(\mathrm{C}_{19} \mathrm{H}_{16} \mathrm{~F}_{2} \mathrm{NaO}_{5}\right) 385.0858(\mathrm{M}+\mathrm{Na})^{+}$: found: 385.0855 .

The product was isolated as a white solid. Yield: 79\%.

${ }^{1}$ H NMR (400 MHz, CDCl $)_{3} \delta 4.72-4.62(\mathrm{~m}, 1 \mathrm{H}), 4.26$ (dd, $\left.J=12.1,3.5 \mathrm{~Hz}, 1 \mathrm{H}\right)$, 4.16 (dd, $J=12.2,5.5$ Hz, 1H), 2.11 (s, 3H), 1.96 - 1.74 (m, 3H), 1.70 - 1.56 (m, 4H), 1.48 - 1.28 (m, 4H), 0.95 (td, $J=7.3,4.1 \mathrm{~Hz}, 6 \mathrm{H}) \mathrm{ppm} ;{ }^{13} \mathbf{C}$ NMR (101 MHz, $\left.\mathbf{C D C l}_{3}\right) \delta$ 170.73, 149.11, 85.26, 73.12, 65.09, 41.49, 39.36, 31.64, 20.83, 16.97, 16.31, 14.43, 14.28 ppm; IR (neat): $v=1737 \mathrm{~cm}^{-1}$; HRMS (ESI+; MeOH): $\mathrm{m} / \mathrm{z}$ calcd. $\left(\mathrm{C}_{13} \mathrm{H}_{22} \mathrm{NaO}_{5}\right)$ $281.1359(\mathrm{M}+\mathrm{Na})^{+}$: found: 281.1362. 
The product was isolated as a colorless oil. Yield: $82 \%$.

${ }^{1}$ H NMR (400 MHz, $\mathbf{C D C l}_{3}$ ) $\delta 4.48$ (ddt, $J=12.2$, 6.1, $3.6 \mathrm{~Hz}, 1 \mathrm{H}$ ), 4.25 (dd, $J=12.2$, $3.3 \mathrm{~Hz}, 1 \mathrm{H}$ ), 4.15 (dd, $J=12.1,6.1 \mathrm{~Hz}, 1 \mathrm{H}), 2.11$ (s, 3H), 2.01 - 1.68 (m, 15H), 1.27 1.08 (m, 10H) ppm; ${ }^{13} \mathbf{C}$ NMR (101 $\left.\mathbf{M H z}, \mathbf{C D C l}_{3}\right) \delta$ 170.77, 151.16, 89.96, 73.86, 64.82, 45.47, 45.00, 27.51, 26.96, 26.87, 26.84, 26.66, 26.57, 26.53, 26.29, 26.28, 26.04, 20.87 ppm; IR (neat): $v=1744 \mathrm{~cm}^{-1}$; HRMS (ESI+; MeOH): $\mathrm{m} / \mathrm{z}$ calcd. $\left(\mathrm{C}_{19} \mathrm{H}_{30} \mathrm{NaO}_{5}\right) 361.1985(\mathrm{M}+\mathrm{Na})^{+}$: found: 361.1981.

The product was isolated as a white solid. Yield: $85 \%$.

${ }^{1}$ H NMR (400 MHz, $\mathbf{C D C l}_{3}$ ) $\delta 4.71$ (ddt, $J=12.4,5.5,3.5 \mathrm{~Hz}, 1 \mathrm{H}$ ), 4.27 (dd, $J=12.2$, $3.5 \mathrm{~Hz}, 1 \mathrm{H}), 4.16$ (dd, $J=12.2,5.4 \mathrm{~Hz}, 1 \mathrm{H}), 2.10-2.09$ (m, 3H), 2.02 - 1.94 (m, 2H), $1.84-1.72$ (m, 4H), $1.62-1.49$ (m, 5H), 1.51 - 1.32 (m, 1H) ppm; ${ }^{13}$ C NMR (101 MHz, $\left.\mathbf{C D C l}_{3}\right) \delta 170.74,148.85$, 82.03, 72.91, 65.06, 38.72, 35.04, 33.74, 25.14, 21.78, 21.45, 20.83 ppm; IR (neat): $v=1736 \mathrm{~cm}^{-1}$; HRMS (ESI+; MeOH): $\mathrm{m} / \mathrm{z}$ calcd. $\left(\mathrm{C}_{12} \mathrm{H}_{18} \mathrm{NaO}_{5}\right) 256.1046(\mathrm{M}+\mathrm{Na})^{+}$: found: 256.1052. 
The product was isolated as a brown oil. Yield: $94 \%$.

${ }^{1}$ H NMR (500 MHz, $\mathbf{C D C l}_{3}$ ) $\delta 4.68$ (ddt, $J=12.4,5.4,3.5 \mathrm{~Hz}, 1 \mathrm{H}$ ), 4.26 (dd, $J=12.1$, $3.4 \mathrm{~Hz}, 1 \mathrm{H}), 4.16$ (dd, $J=12.1,5.5 \mathrm{~Hz}, 1 \mathrm{H}), 2.19-1.99$ (m, 6H), $1.80-1.32$ (m, 13H) ppm; ${ }^{13}$ C NMR (126 MHz, $\mathbf{C D C l}_{3}$ ) $\delta$ 170.73, 148.81, 86.10, 73.20, 65.09, 37.98, 33.17, 32.78, 28.10, 27.69, 24.95, 21.88, 21.42, 20.83 ppm; IR (neat): $v=1738 \mathrm{~cm}^{-1}$; HRMS (ESI+; MeOH): $m / z$ calcd. $\left(\mathrm{C}_{14} \mathrm{H}_{22} \mathrm{NaO}_{5}\right) 293.1359(\mathrm{M}+\mathrm{Na})^{+}$: found: 293.1362.

The product was isolated as a colorless oil. Yield: 96\%, 63:37 $d r$.

${ }^{1}$ H NMR (400 MHz, $\mathbf{C D C l}_{3}$ ) $\delta 7.34-7.27$ (m, 0.8H), $7.24-7.15$ (m, 3.17H), 4.86 (ddt, $J=11.9,5.4,3.5 \mathrm{~Hz}, 0.37 \mathrm{H}$ ), $4.32-4.08$ (m, 2.63H), $2.47-2.28$ (m, 4.09H), 2.23 - 2.12 (m, 1.02H), 2.09- 2.08 (m, $2.83 \mathrm{H}), 1.78$ (s, 1.08H), 1.71 (s, $1.86 \mathrm{H}) \mathrm{ppm} ;{ }^{13} \mathrm{C}$ NMR (101 MHz, $\left.\mathbf{C D C l}_{3}\right) \delta$ 170.68, 170.65, 148.59, 148.53, 140.96, 139.07, 138.26, 138.11, 129.99, 129.54, 124.00, 123.76, 84.08, 83.14, 74.06, 73.75, 64.86, 64.69, 35.73, 35.50, 31.26, 27.66, 21.11, 21.07, 20.80, 20.78 ppm; IR (neat): $v=1743 \mathrm{~cm}^{-1}$; HRMS (ESI+; MeOH): $m / z$ calcd. $\left(\mathrm{C}_{15} \mathrm{H}_{18} \mathrm{NaO}_{5}\right) 301.1046(\mathrm{M}+\mathrm{Na})^{+}$: found: 301.1050 . 
The product was isolated as a colorless oil. Yield: 90\%, 7:3 $d r$.

${ }^{1}$ H NMR (400 MHz, CDCl $) \delta 7.45$ - 7.31 (m, 3.53H), 7.30 - 7.24 (m, 1.51H), 4.84 (ddt, $J=11.7,5.5,3.6 \mathrm{~Hz}, 1 \mathrm{H}), 4.30-4.08$ (m, 2.7H), $2.49-2.35$ (m, 0.99H), 2.26 2.13 (m, 1.34H), $2.10-2.04(\mathrm{~m}, 2.54 \mathrm{H}), 2.03-1.95$ (m, 1.73H), 0.84 (t, $J=7.4 \mathrm{~Hz}$, 2.10H), 0.79 (t, $\left.J=7.4 \mathrm{~Hz}, 0.9 \mathrm{H}) \mathrm{ppm} ;{ }^{13} \mathbf{C} \mathbf{~ N M R ~ ( 1 0 1 ~} \mathbf{M H z}, \mathbf{C D C l}_{3}\right) \delta 170.64,170.60$, 148.68, 148.47, 141.82, 140.50, 129.25, 128.80, 128.32, 128.07, 124.74, 124.42, 86.60, 85.88, 73.87, 73.53, 64.84, 64.74, 36.32, 34.46, 33.87, 33.47, 20.78, 20.76, 7.76, 7.33 ppm; IR (neat): $v=1735 \mathrm{~cm}^{-1}$; HRMS (ESI+; MeOH): $\mathrm{m} / \mathrm{z}$ calcd. $\left(\mathrm{C}_{15} \mathrm{H}_{18} \mathrm{NaO}_{5}\right)$ $301.1046(\mathrm{M}+\mathrm{Na})^{+}$: found: 301.1045.

The product was isolated as a colorless oil. Yield: 83\%, 72:28 $d r$.

${ }^{1} \mathbf{H}$ NMR (500 MHz, $\left.\mathbf{C D C l}_{3}\right) \delta 7.30$ (d, $\left.J=8.6 \mathrm{~Hz}, 0.29 \mathrm{H}\right), 7.19-7.14(\mathrm{~m}, 0.71 \mathrm{H})$, 7.05 - 7.01 (m, 2H), 4.84 (ddt, $J=12.1,5.3,3.5 \mathrm{~Hz}, 0.28 \mathrm{H}), 4.35-4.29$ (m, 1.03H), $4.24-4.19$ (m, 1.04H), 4.14 (dd, $J=12.2,5.0 \mathrm{~Hz}, 0.72 \mathrm{H}), 2.76$ (dd, $J=14.6,3.2 \mathrm{~Hz}$, $0.71 \mathrm{H}), 2.53-2.36$ (m, 3.63H), $2.34-2.26$ (m, 3.45H), $2.17-2.06$ (m, 3.81H), 1.86 (s, 0.89H), 1.77 (s, 2.16H) ppm; ${ }^{13} \mathbf{C}$ NMR (126 MHz, $\left.\mathbf{C D C l}_{3}\right) \delta$ 170.68, 170.65, $148.60,148.49,138.40,138.29,138.25,136.12,134.50,134.08,133.84,127.50$, 127.00, 125.31, 124.77, 85.11, 84.51, 74.14, 73.47, 64.85, 64.82, 34.75, 34.49, 29.43, 26.89, 22.11, 22.04, 20.82, 20.79 ppm; IR (neat): $v=1736 \mathrm{~cm}^{-1}$; HRMS (ESI+; MeOH): $m / z$ calcd. $\left(\mathrm{C}_{16} \mathrm{H}_{20} \mathrm{NaO}_{5}\right) 315.1197(\mathrm{M}+\mathrm{Na})^{+}$: found: 315.1203. 
The product was isolated preparative TLC, white solid, eluent: 25\% EA in hexane. Yield: 76\%, 91:9 $d r$.

${ }^{1}$ H NMR (500 MHz, $\left.\mathbf{C D C l}_{3}\right) \delta 7.91-7.81$ (m, 3.85H), $7.56-7.50$ (m, 1.99H), 7.33 (dd, $J=8.6,2.1 \mathrm{~Hz}, 0.90 \mathrm{H}$ ), 4.92 (ddt, $J=12.2,5.3,3.5 \mathrm{~Hz}, 0.09 \mathrm{H}$ ), 4.33 (dd, $J=12.2$, $3.6 \mathrm{~Hz}, 0.08 \mathrm{H}), 4.26-4.10$ (m, 2.83H), 2.58 (dd, $J=14.4,3.0 \mathrm{~Hz}, 0.90 \mathrm{H}), 2.27$ (dd, $J=$ 14.3, $12.1 \mathrm{~Hz}, 0.97 \mathrm{H}), 2.09-2.04$ (m, 2.86H), 1.89 (s, $0.24 \mathrm{H}), 1.82$ (s, 2.7H) ppm; ${ }^{13} \mathrm{C}$ NMR (126 MHz, $\left.\mathbf{C D C l}_{3}\right) \delta$ 170.57, 148.54, 141.00, 139.16, 133.20, 133.11, 132.86, 132.84, 129.53, 128.92, 128.44, 128.41, 127.70, 127.12, 126.96, 126.85, 126.75, 123.53, 122.69, 121.80, 121.53, 84.20, 83.25, 74.10, 73.76, 64.81, 64.61, 35.63, 35.41, 31.04, 27.63, 20.78, 20.74 ppm; IR (neat): $v=1735 \mathrm{~cm}^{-1}$; HRMS (ESI+; MeOH): $\mathrm{m} / \mathbf{z}$ calcd. $\left(\mathrm{C}_{18} \mathrm{H}_{18} \mathrm{NaO}_{5}\right) 337.1046(\mathrm{M}+\mathrm{Na})^{+}$: found: 337.1055.

The product was isolated as a white solid. Yield: 95\%.

${ }^{1}$ H NMR (400 MHz, $\mathbf{C D C l}_{3}$ ) $\delta 7.24-7.18$ (m, 4H), 4.83 (dtd, $J=10.8$, 5.0, 3.6 Hz, 1H), 4.33 (dd, $J=12.2,3.6 \mathrm{~Hz}, 1 \mathrm{H}$ ), 4.23 (dd, $J=12.2,5.3 \mathrm{~Hz}, 1 \mathrm{H}$ ), 3.39 (dd, $J=19.3$, $16.6 \mathrm{~Hz}, 2 \mathrm{H}), 3.19$ (dd, $J=16.5,2.9 \mathrm{~Hz}, 2 \mathrm{H}), 2.26-2.08$ (m, 5H) ppm; ${ }^{13} \mathbf{C}$ NMR (101 MHz, $\left.\mathbf{C D C l}_{3}\right) \delta 170.69,148.27,138.84,138.42,127.63,127.47,124.88,124.82,89.72$, 74.38, 64.88, 46.39, 44.53, 32.83, 20.83 ppm; IR (neat): $v=1734 \mathrm{~cm}^{-1}$; HRMS (ESI+; MeOH): $m / z$ calcd. $\left(\mathrm{C}_{15} \mathrm{H}_{16} \mathrm{NaO}_{5}\right) 299.0890(\mathrm{M}+\mathrm{Na})^{+}$: found: 299.0882 . 
The product was isolated by preparative TLC, light yellow oil, eluent: 25\% EA in hexane. Yield: 80\%, 94:6 dr.

${ }^{1}$ H NMR (500 MHz, $\left.\mathbf{C D C l}_{3}\right) \delta 7.66$ - 7.61 (m, 1.97H), $7.61-7.55$ (m, 1.97H), 7.48 7.43 (m, 1.97H), $7.41-7.34(\mathrm{~m}, 2.79 \mathrm{H}), 4.92-4.87(\mathrm{~m}, 0.06 \mathrm{H}), 4.37$ - 4.13 (m, 2.94H), 2.50 (dd, $J=14.3,3.1 \mathrm{~Hz}, 0.93 \mathrm{H}$ ), 2.24 (dd, $J=14.3,12.3 \mathrm{~Hz}, 0.99 \mathrm{H}$ ), 2.09 (s, 2.43H), 1.78 (s, 2.76H) ppm; ${ }^{13} \mathbf{C}$ NMR (126 MHz, $\left.\mathbf{C D C l}_{3}\right) \delta$ 170.64, 148.47, 141.43, 140.94, 140.10, 129.05, 128.05, 127.89, 127.20, 124.63, 84.00, 74.09, 64.68, 35.52, 31.26, 20.80 ppm; IR (neat): $v=1736 \mathrm{~cm}^{-1}$; HRMS (ESI+; MeOH): $\mathrm{m} / \mathrm{z}$ calcd. $\left(\mathrm{C}_{20} \mathrm{H}_{20} \mathrm{NaO}_{5}\right) 363.1203(\mathrm{M}+\mathrm{Na})^{+}$: found: 363.1201.

Note: product 3a was isolated when using the conditions of Table 1, entry 17: ${ }^{[8]}$

The product was isolated as white solid, eluent: 10\%-25\% EA in hexane. Yield: 15\%.

${ }^{1}$ H NMR (400 MHz, $\mathbf{C D C l}_{3}$ ) $\delta 7.54$ - 7.48 (m, 2H), 7.44 - 7.39 (m, 2H), 7.35 - 7.27 (m, 4H), $7.25-7.17$ (m, 2H), 4.55 (s, 1H), 4.16 (dd, $J=9.9,5.2$ Hz, 1H), 3.96 (ddd, $J=$ 9.9, 2.6, $0.9 \mathrm{~Hz}, 1 \mathrm{H}$ ), 2.87 (dd, $J=13.5,6.3 \mathrm{~Hz}, 1 \mathrm{H}$ ), 2.78 (ddd, $J=13.5,3.0,0.9 \mathrm{~Hz}$, 1H), 1.53 (s, 1H) ppm; ${ }^{13} \mathbf{C}$ NMR (101 MHz, $\mathbf{C D C l}_{3}$ ) $\delta$ 146.22, 146.18, 128.57, 128.43, 127.18, 127.06, 125.87, 125.75, 87.89, 75.29, 73.40, 48.49 ppm. 
Note: this tetrahydrofuran product (3l-Ac) was the only product isolated while attempting the synthesis of cyclic carbonate 2l:

The product was isolated as white solid, eluent: 2\%-5\% EA in hexane. Yield: 89\%, 97:3 $d r$.

${ }^{1}$ H NMR (500 MHz, $\mathbf{C D C l}_{3}$ ) $\delta 7.55$ - 7.50 (m, 2H), 7.41 - 7.32 (m, 3H), 5.38 (ddt, $J=$ 6.8, 4.4, $2.3 \mathrm{~Hz}, 1 \mathrm{H}$ ), 4.34 (dd, $J=10.2,4.6 \mathrm{~Hz}, 1 \mathrm{H}$ ), 4.13 (ddq, $J=10.2,2.3,1.1 \mathrm{~Hz}$, 1H), 2.97 (dd, $J=14.4,6.3 \mathrm{~Hz}, 1 \mathrm{H}$ ), 2.58 (ddt, $J=14.4,2.5,1.1 \mathrm{~Hz}, 1 \mathrm{H}$ ), 1.77 (s, 3H) ppm; ${ }^{13} \mathbf{C}$ NMR (126 MHz, $\left.\mathbf{C D C l}_{3}\right) \delta$ 170.63, 137.82, 128.93, 128.60, 128.23, 126.66, 126.57, 126.56, 124.39, 122.13, 85.85, 85.62, 85.38, 85.15, 74.46, 74.30, 40.44, 20.75 ppm; ${ }^{19}$ F NMR (471 MHz, $\mathbf{C D C l}_{3}$ ) $\delta$-78.80, -79.10 ppm; HRMS (ESI+; MeOH): m/z calcd. $\left(\mathrm{C}_{13} \mathrm{H}_{13} \mathrm{~F}_{3} \mathrm{NaO}_{3}\right) 297.0709(\mathrm{M}+\mathrm{Na})^{+}$: found: 297.0719. 


\section{S37: References:}

[1] N. A. Weires, Y. Slutskyy, L. E. Overman, Angew. Chem. Int. Ed. 2019, 58, 85618565.

[2] Y. Zhang, X. Jia, J.-X. Wang, Eur. J. Org. Chem., 2009, 2983-2986.

[3] S. Sopeña, M. Cozzolino, C. Maquilón, E. C. Escudero-Adán, M. Martínez Belmonte, A.W. Kleij, Angew.Chem. Int. Ed. 2018, 57, 11203-11207.

[4] J. Rintjema, R. Epping, G. Fiorani, E. Martin, E. C. Escudero-Adán, A. W. Kleij, Angew.Chem.Int. Ed. 2016, 55, 3972-3976.

[5] C. J. Whiteoak, N. Kielland, V. Laserna, F. Castro-Gómez, E. Martin, E. C. Escudero-Adán, C. Bo, A. W. Kleij, Chem. Eur. J. 2014, 20, 2264-2275.

[6] Z. Xie, G. Li, G. Zhao, J. Wang, Chin. J. Chem. 2010, 28, 1212-1216.

[7] S. Silver, A. Leppänen, R. Sjöholm, A. Penninkangas, R. Leino, Eur. J. Org. Chem. 2005, 1058-1081.

[8] M. Gamedze, C. Nkambule, Tetrahedron Lett. 2015, 56, 1825-1829. 


\section{S38: IR, ${ }^{1} \mathrm{H}$ NMR, ${ }^{13} \mathrm{C}$ NMR and ${ }^{19} \mathrm{~F}$ NMR spectra}

Note: for all compounds in this section the order of the presented spectra is: ${ }^{1} \mathbf{H}$, ${ }^{13} \mathrm{C},{ }^{19} \mathrm{~F}$ (where applicable) and IR

NMR spectra for the homoallylic alcohols:

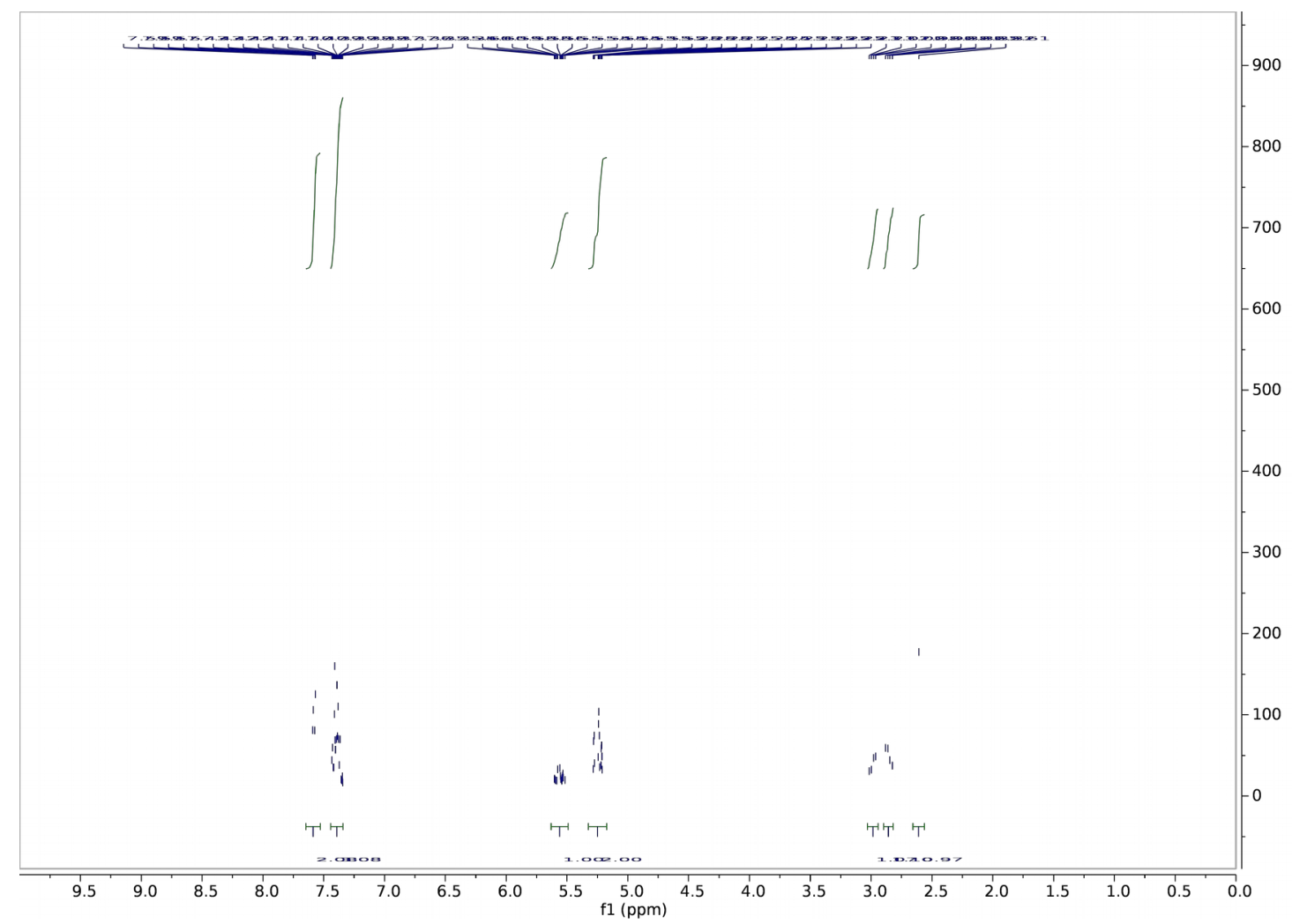




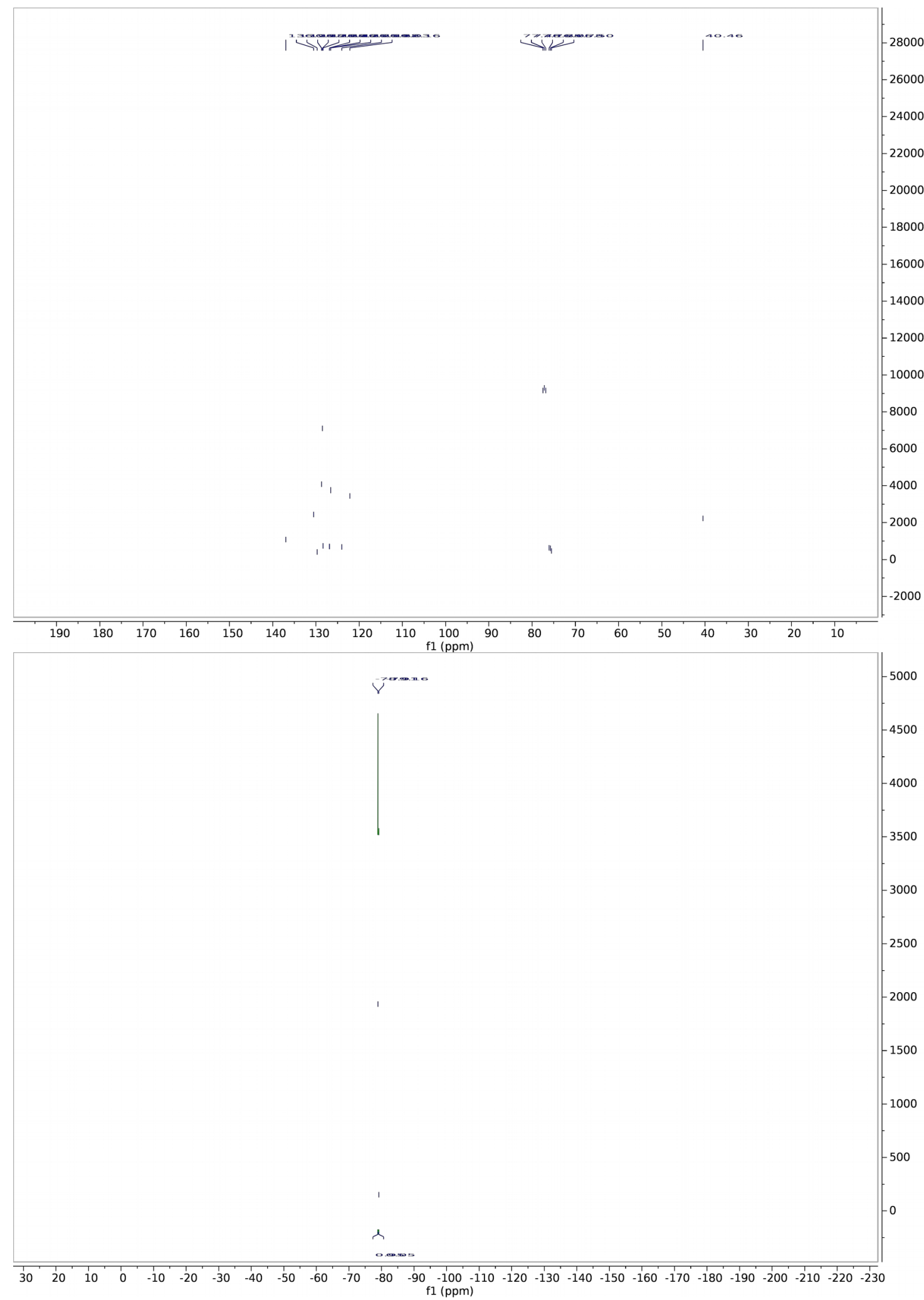



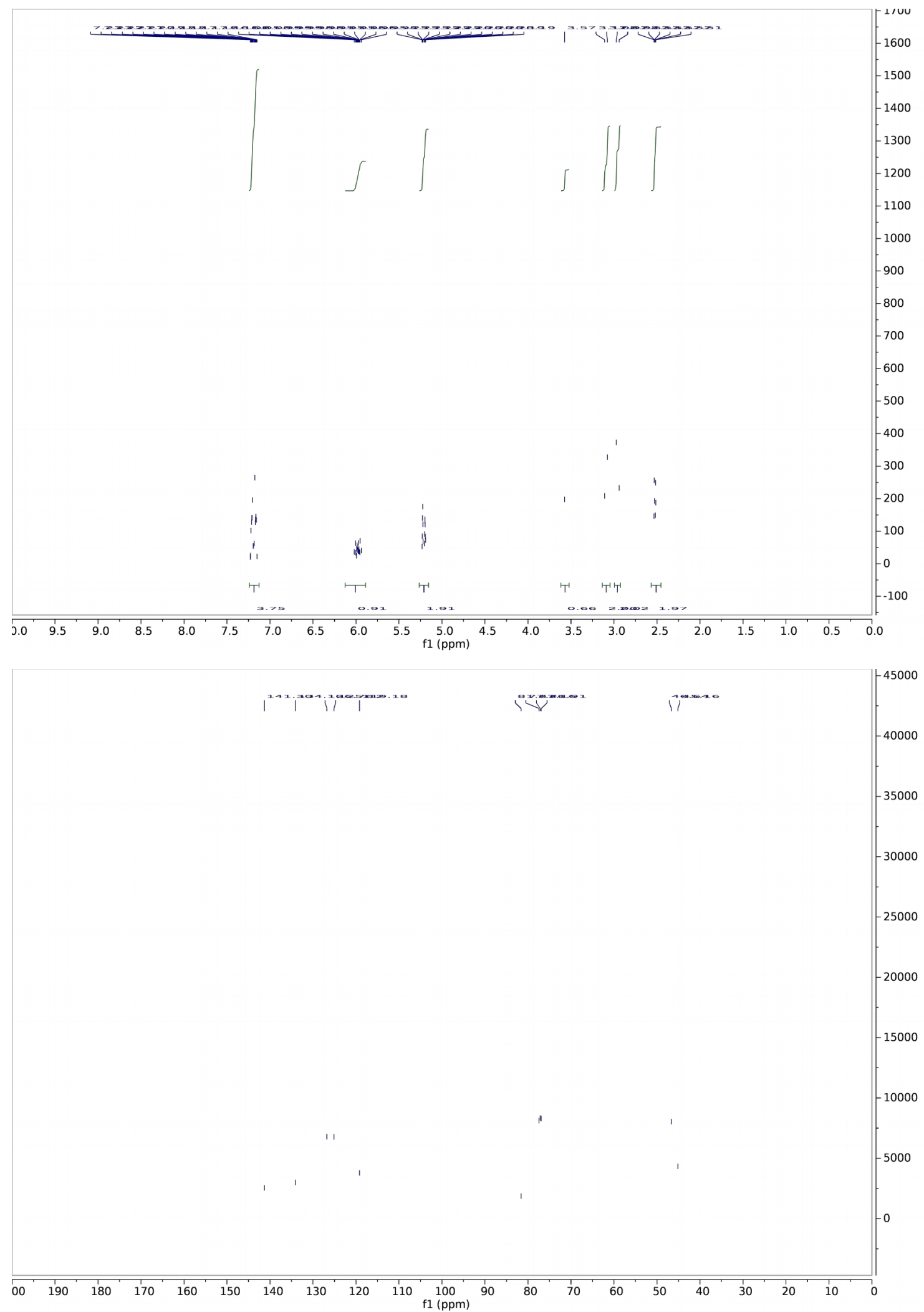


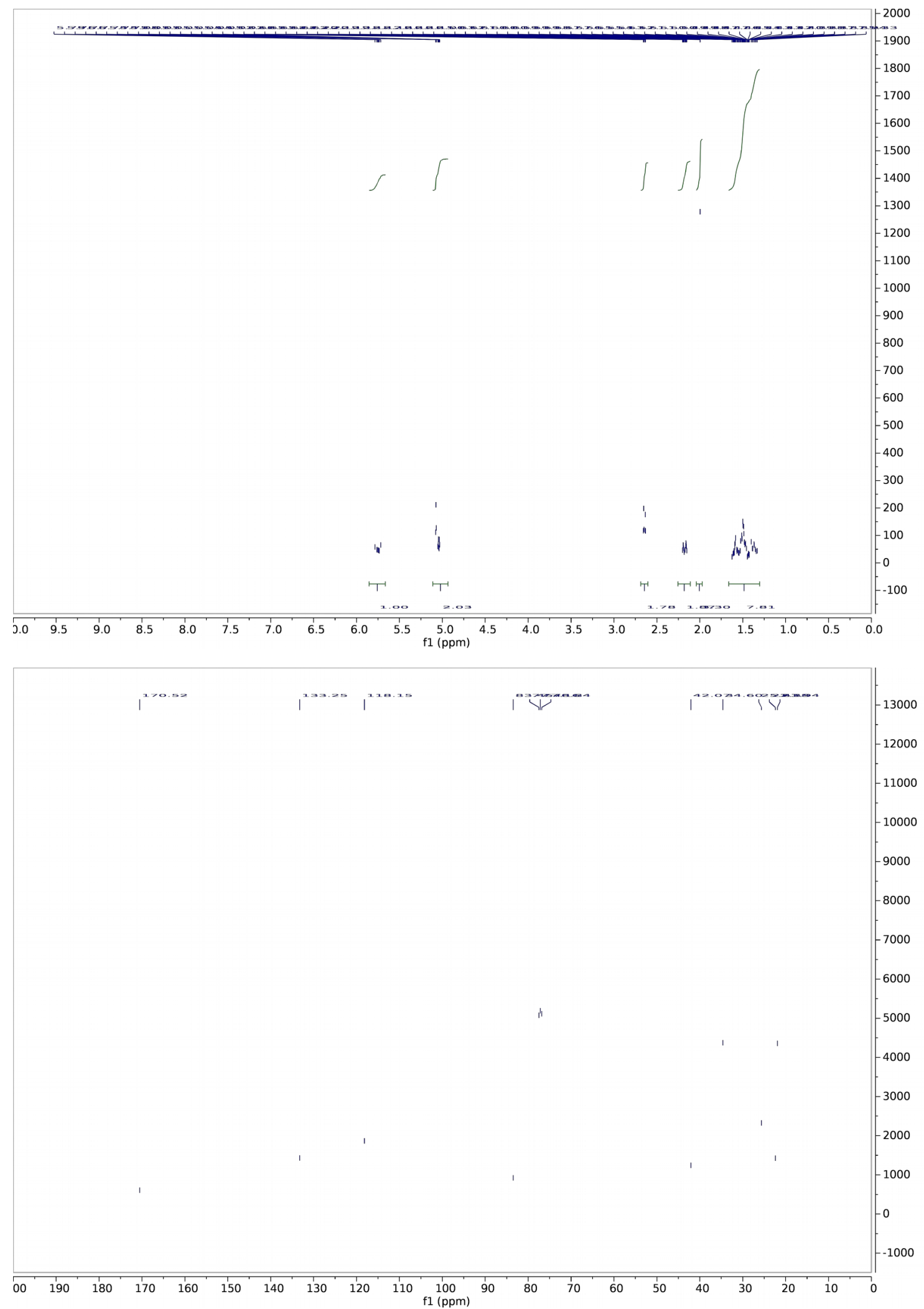


Spectra for epoxy alcohol products B1-B18:

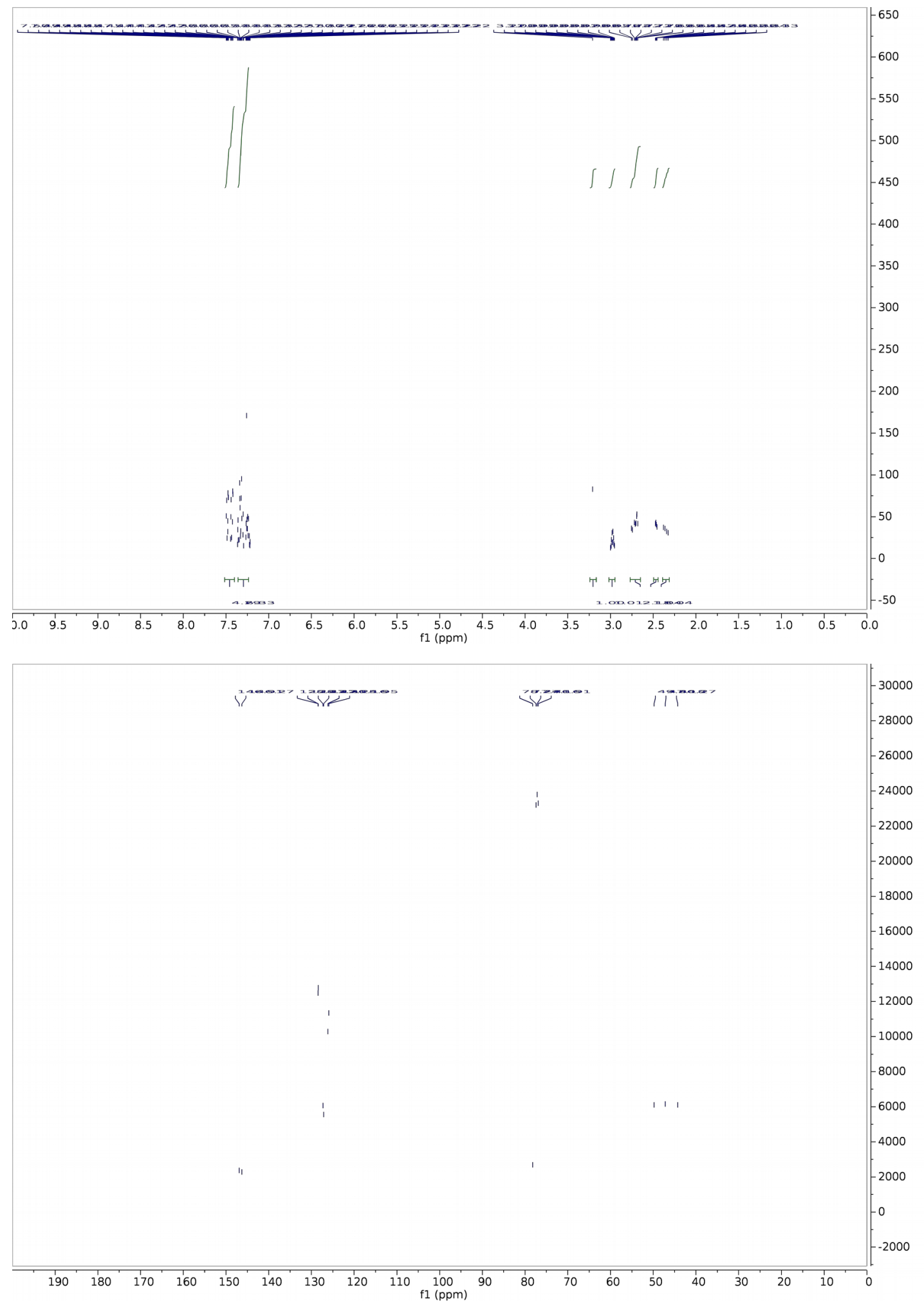




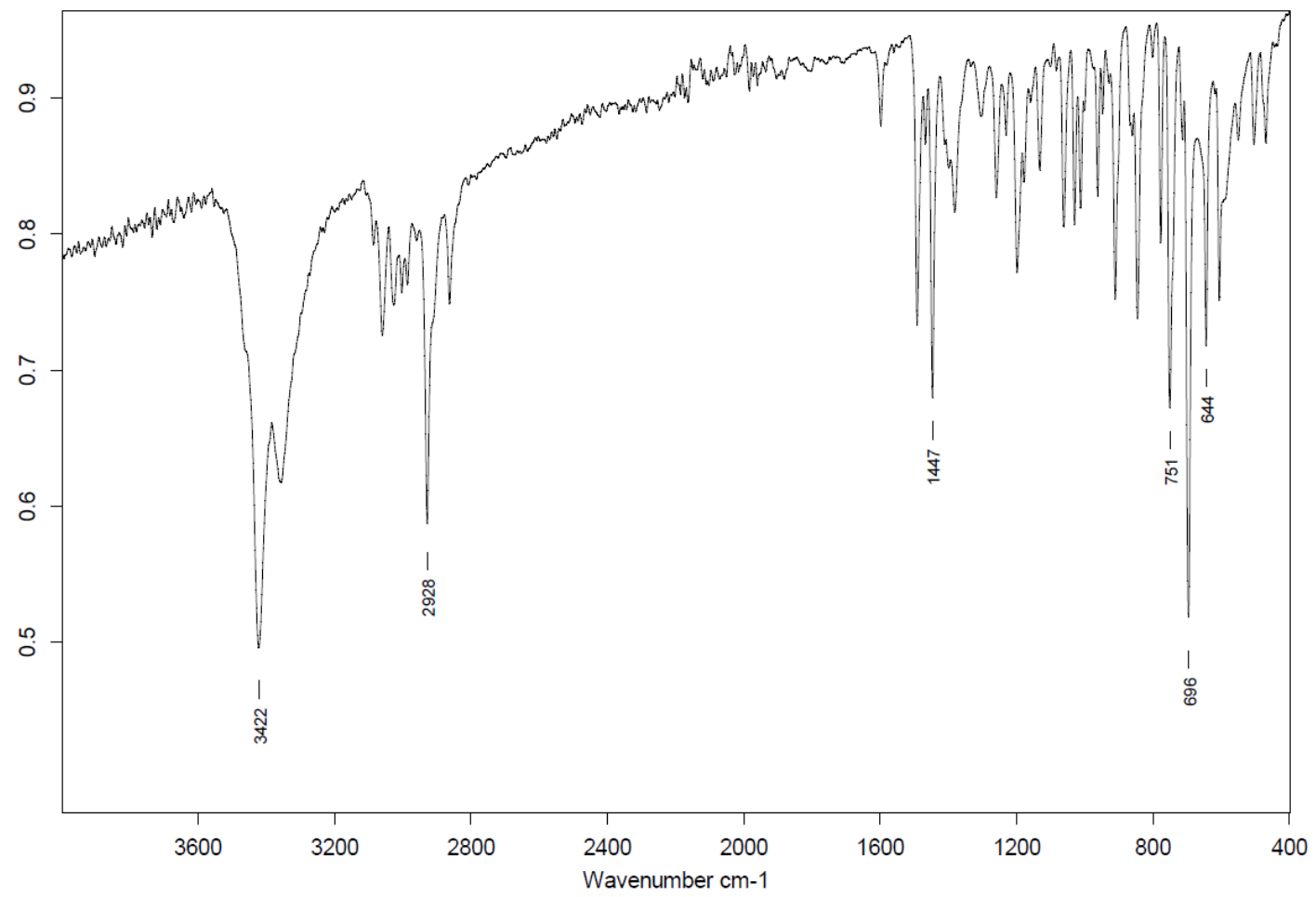




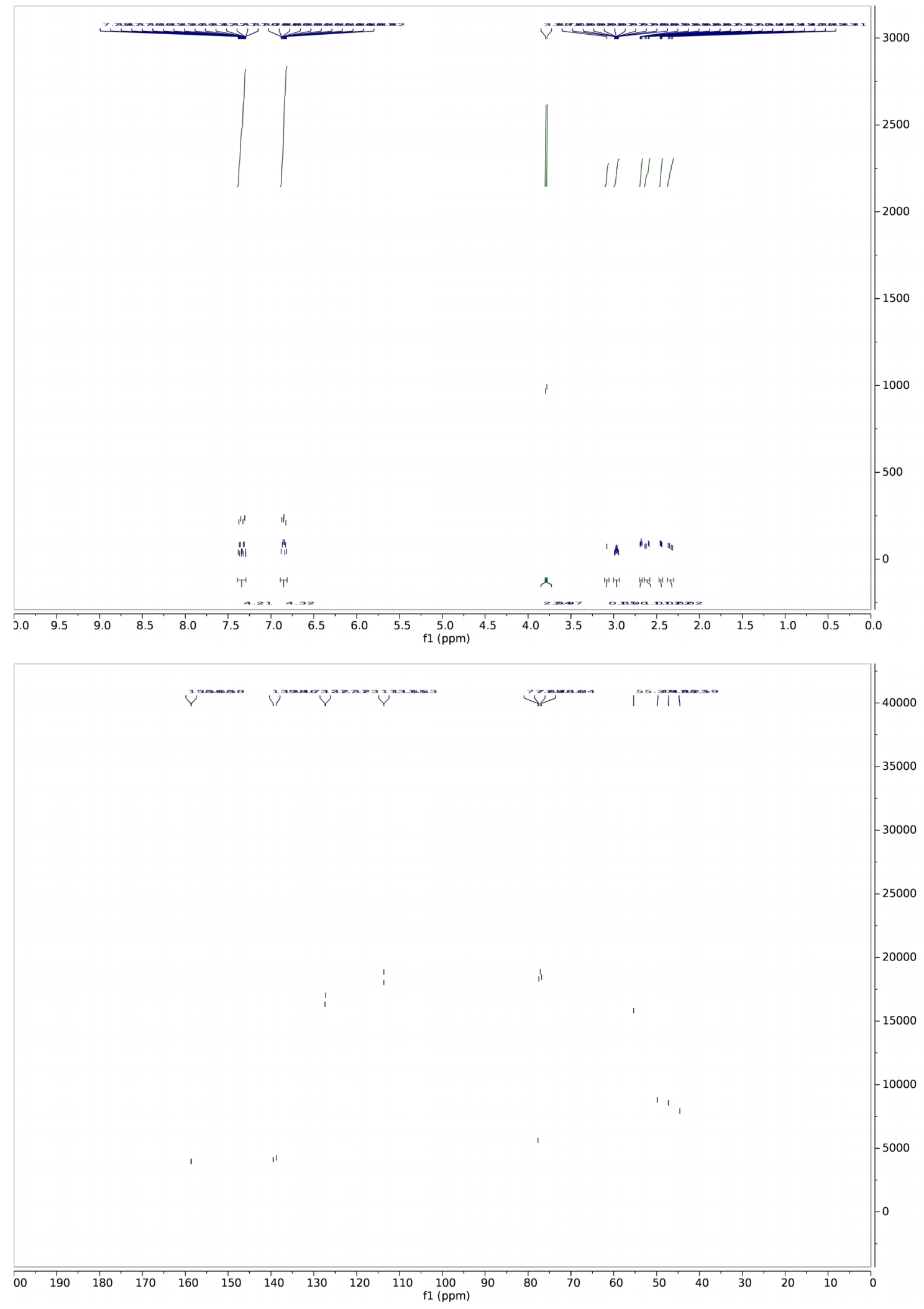




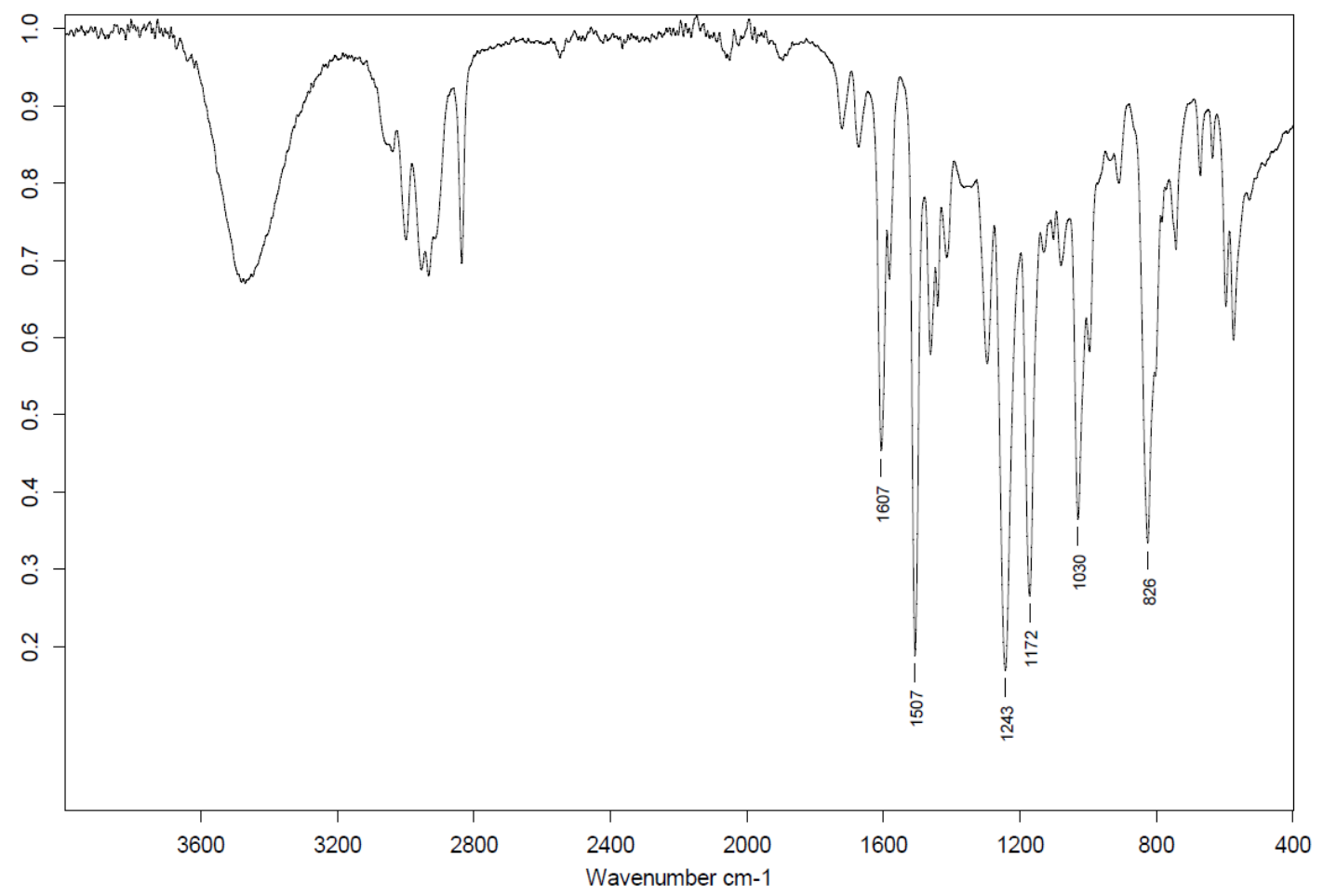




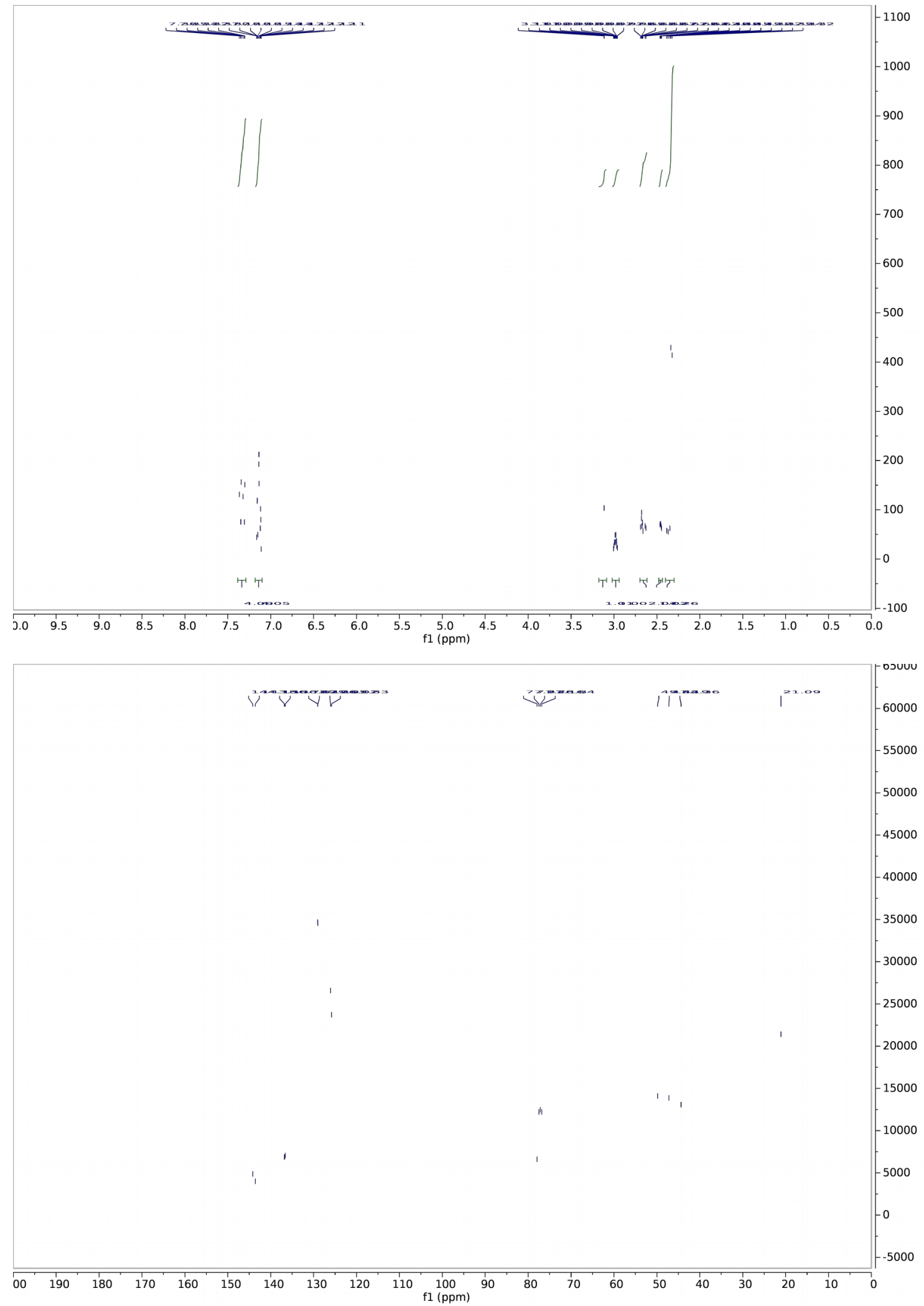




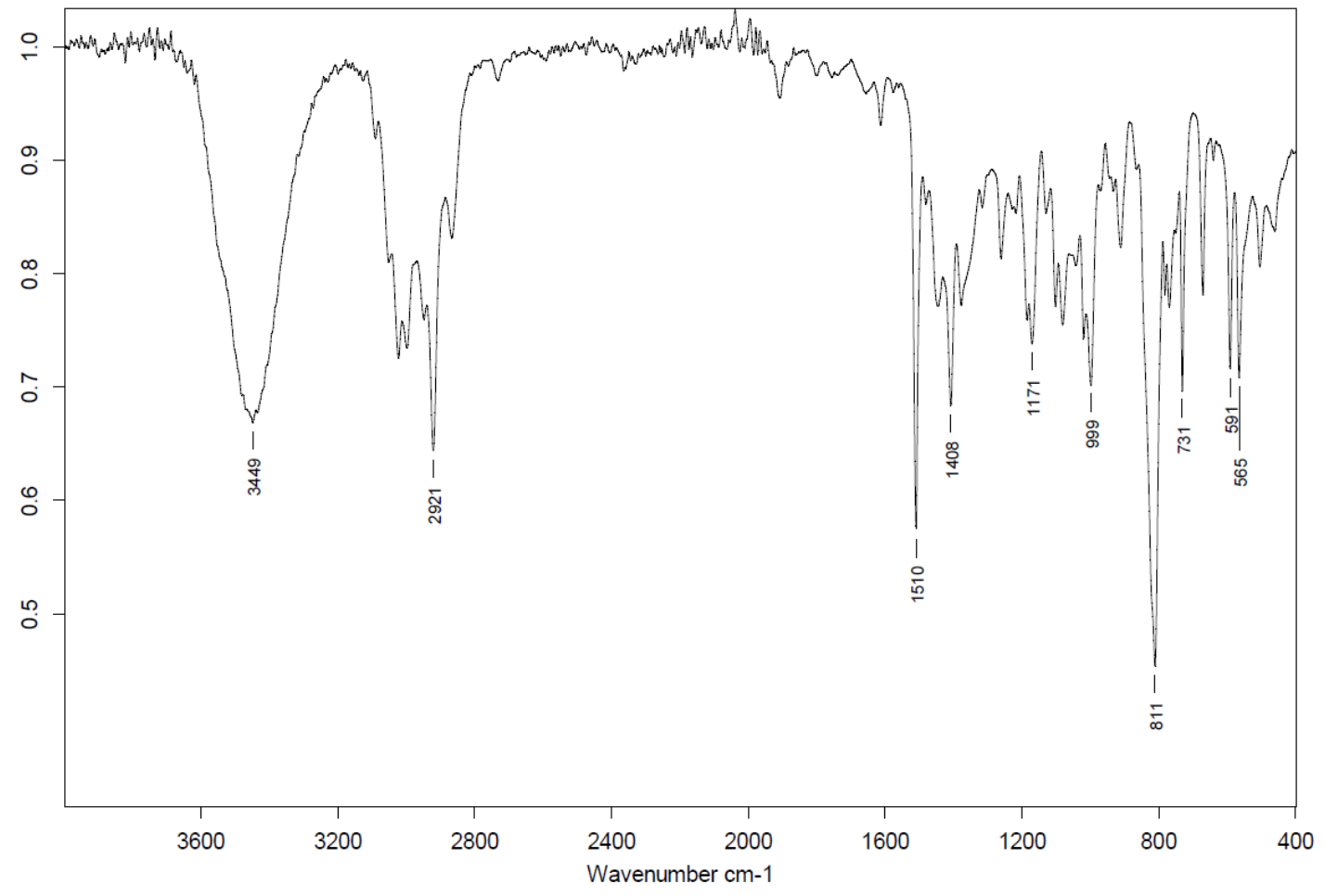




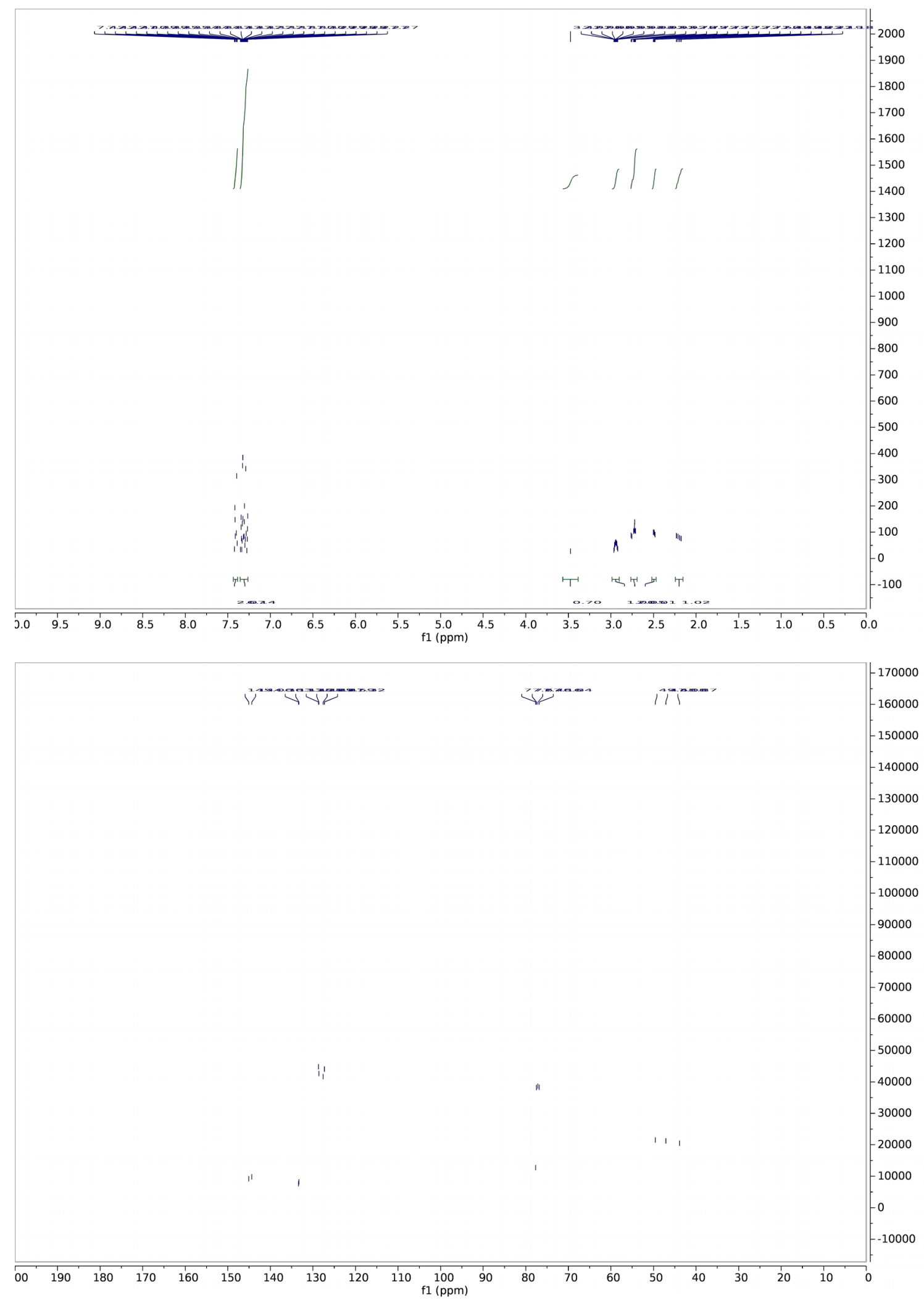




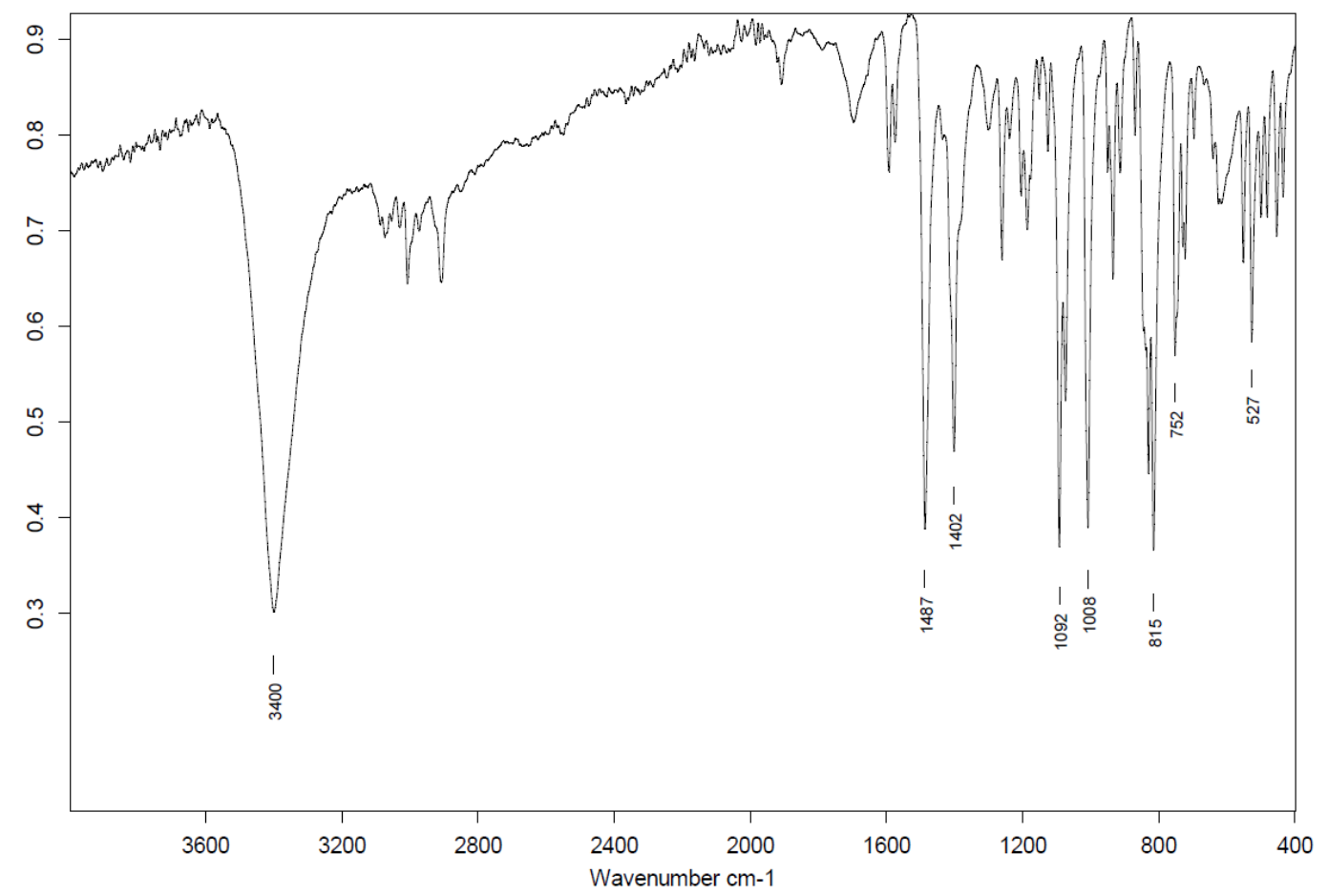




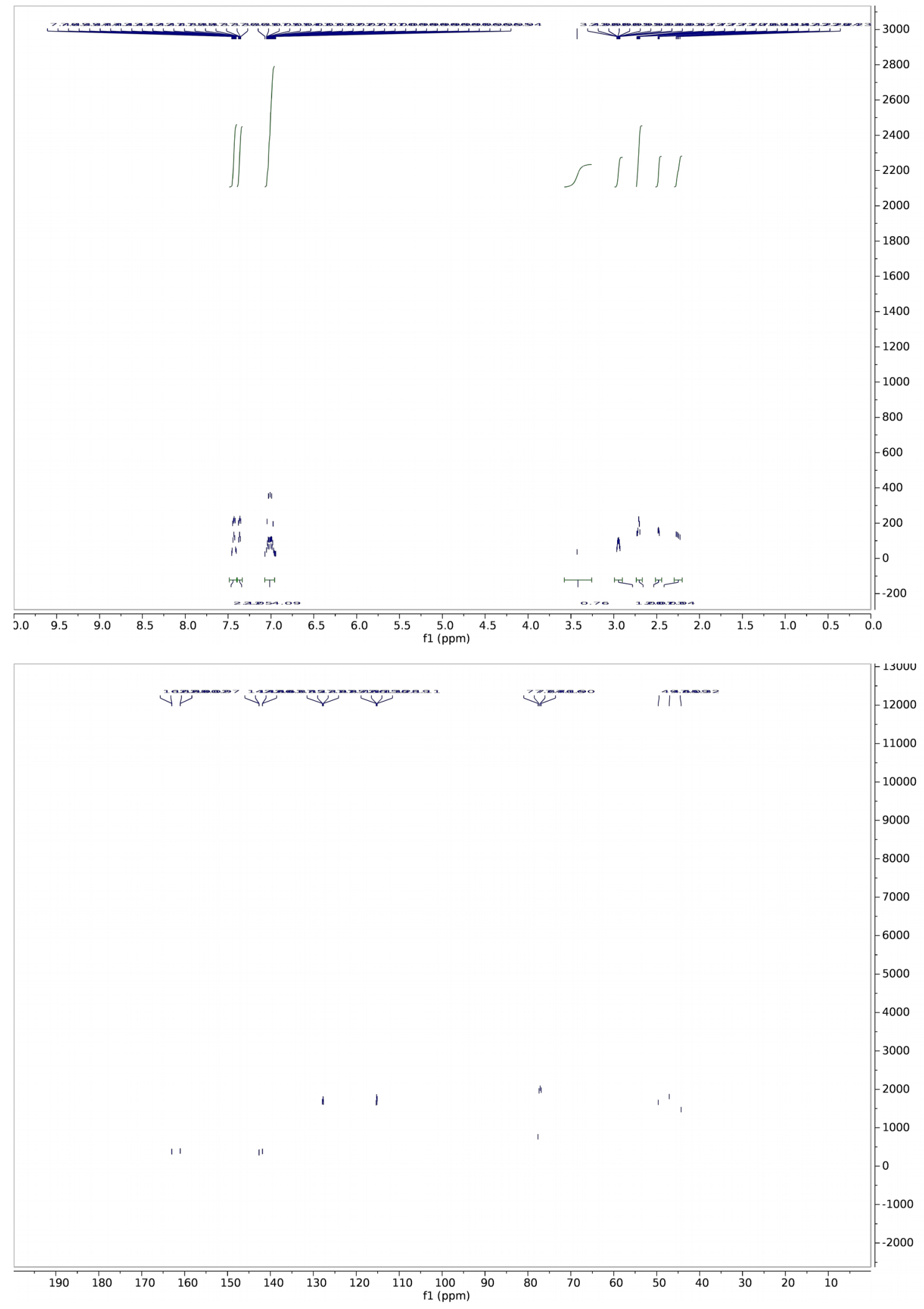



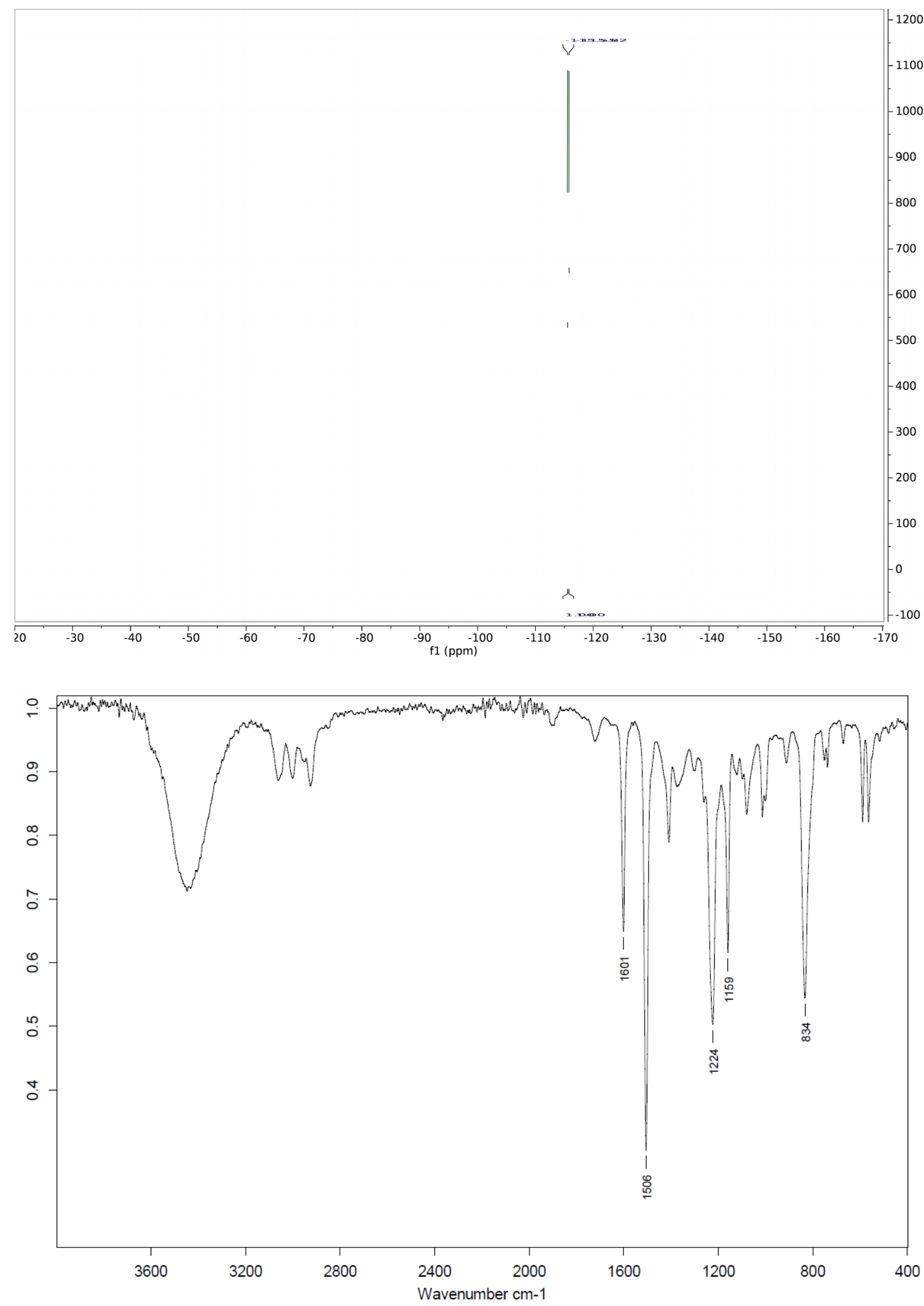

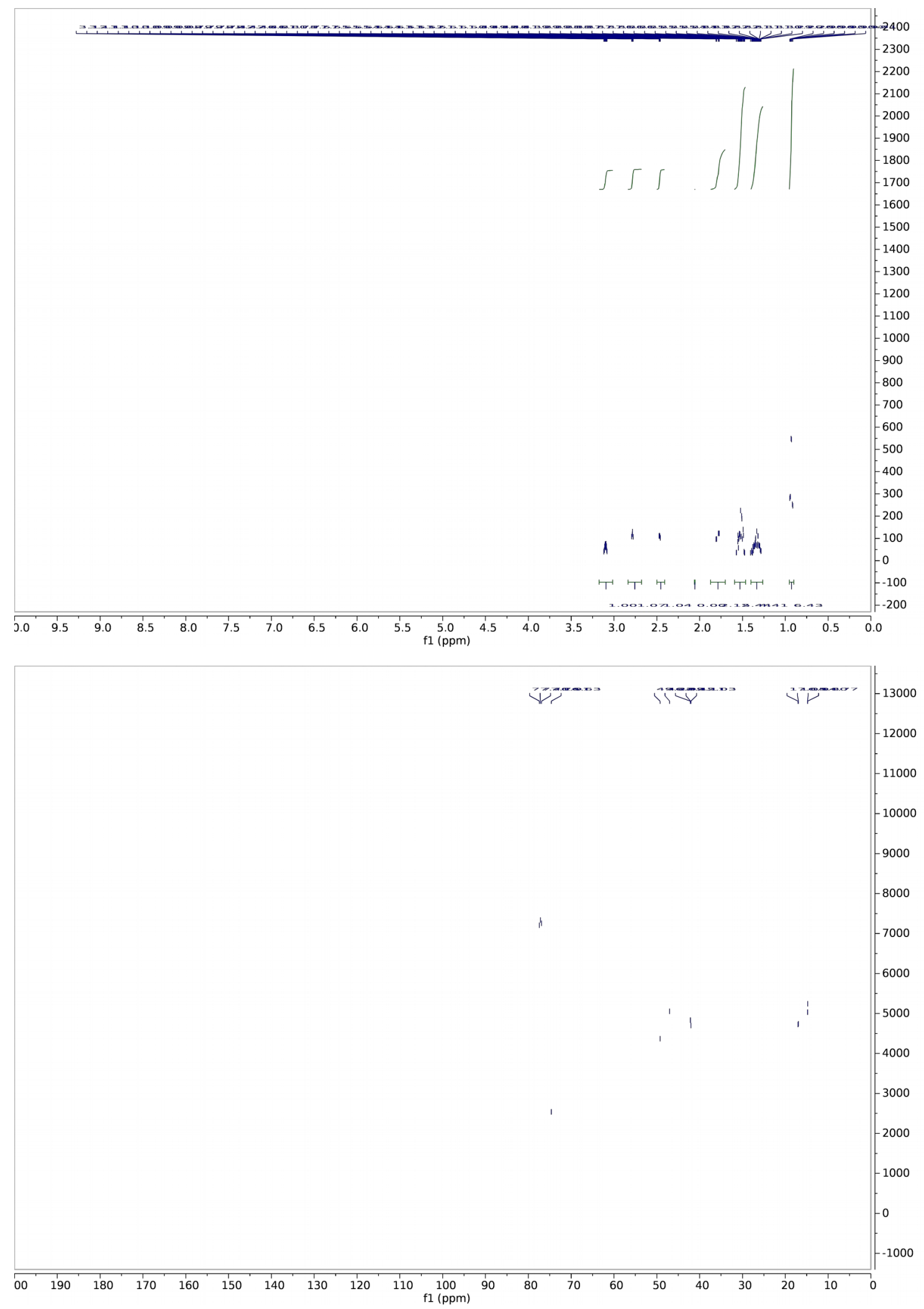


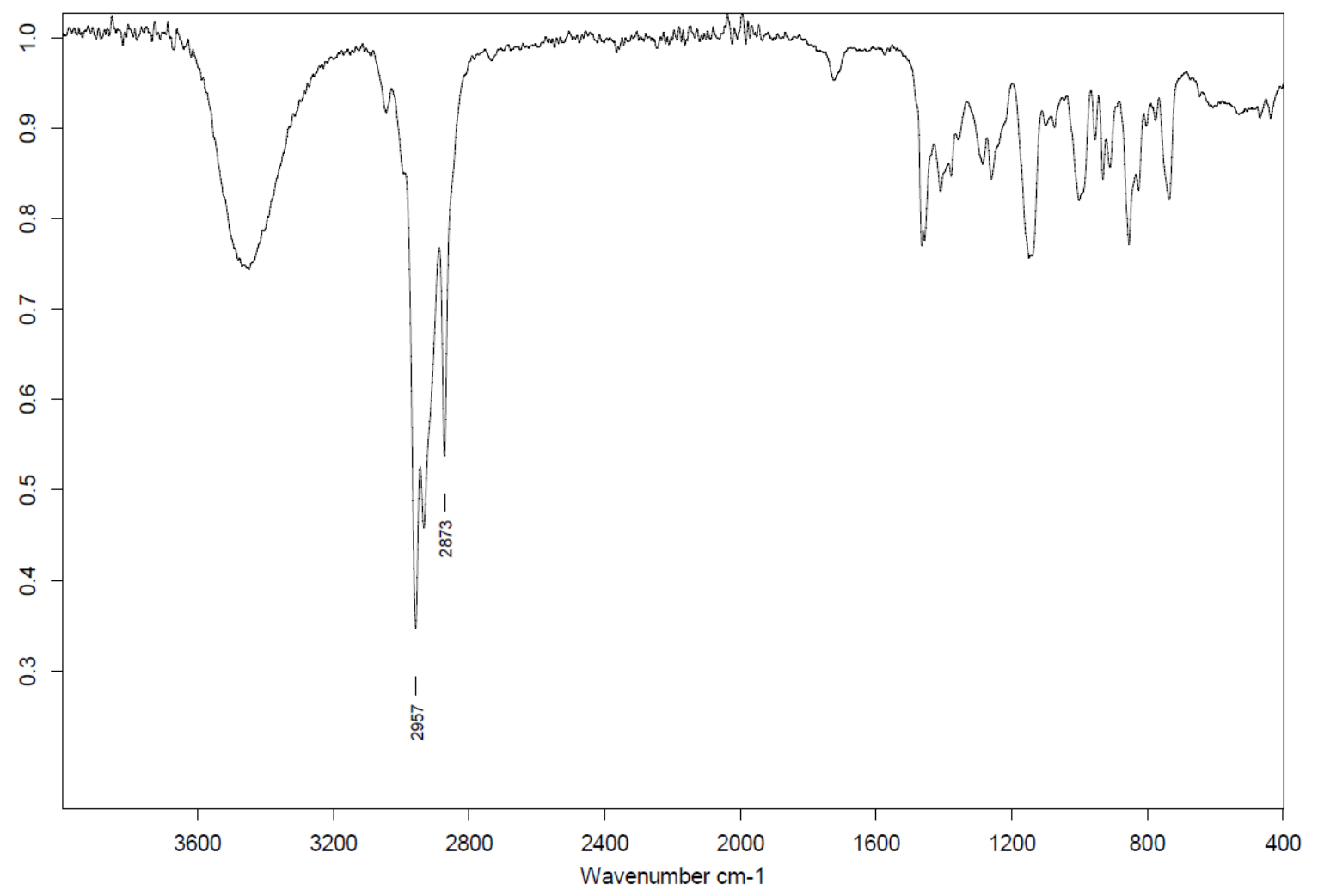




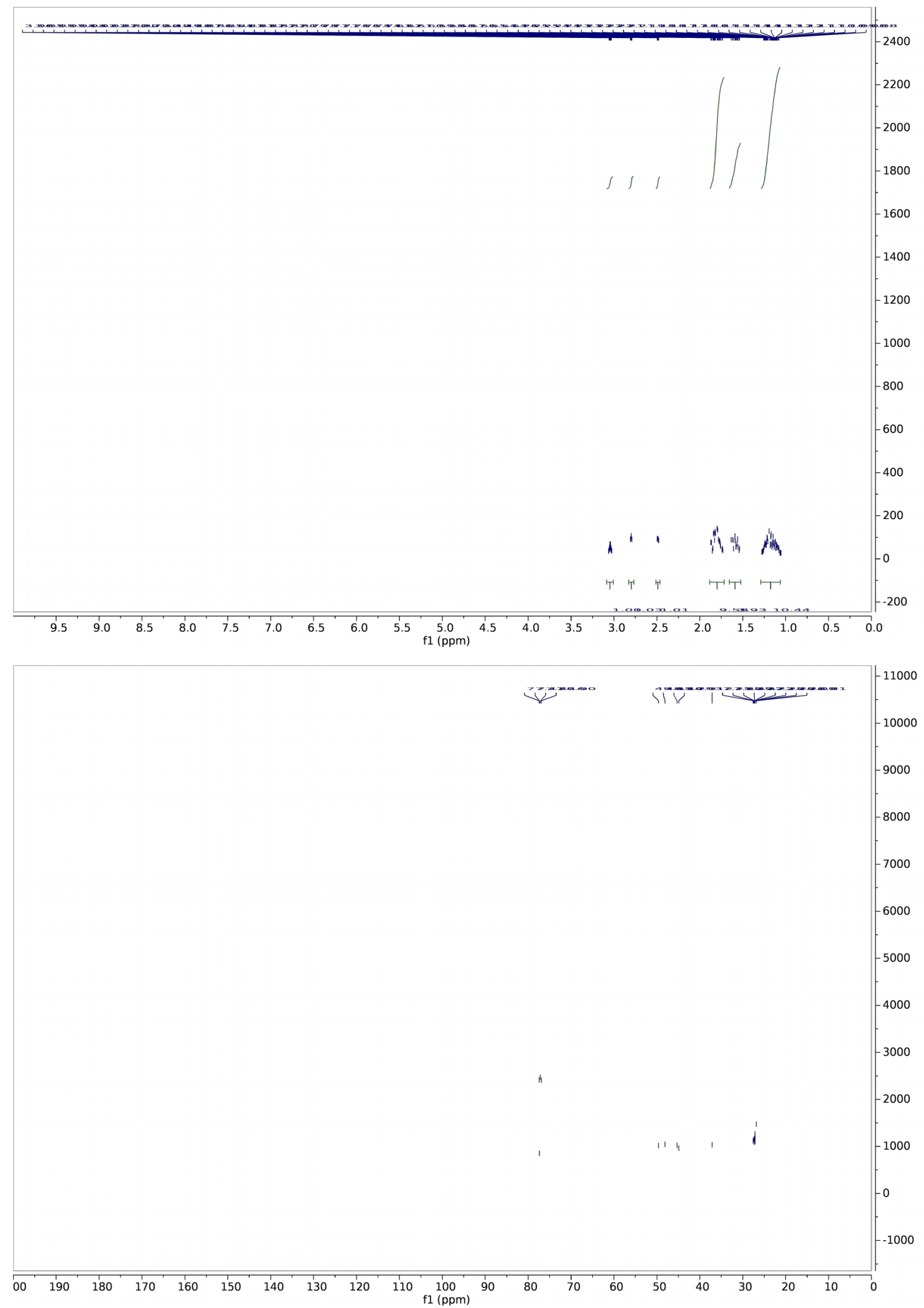




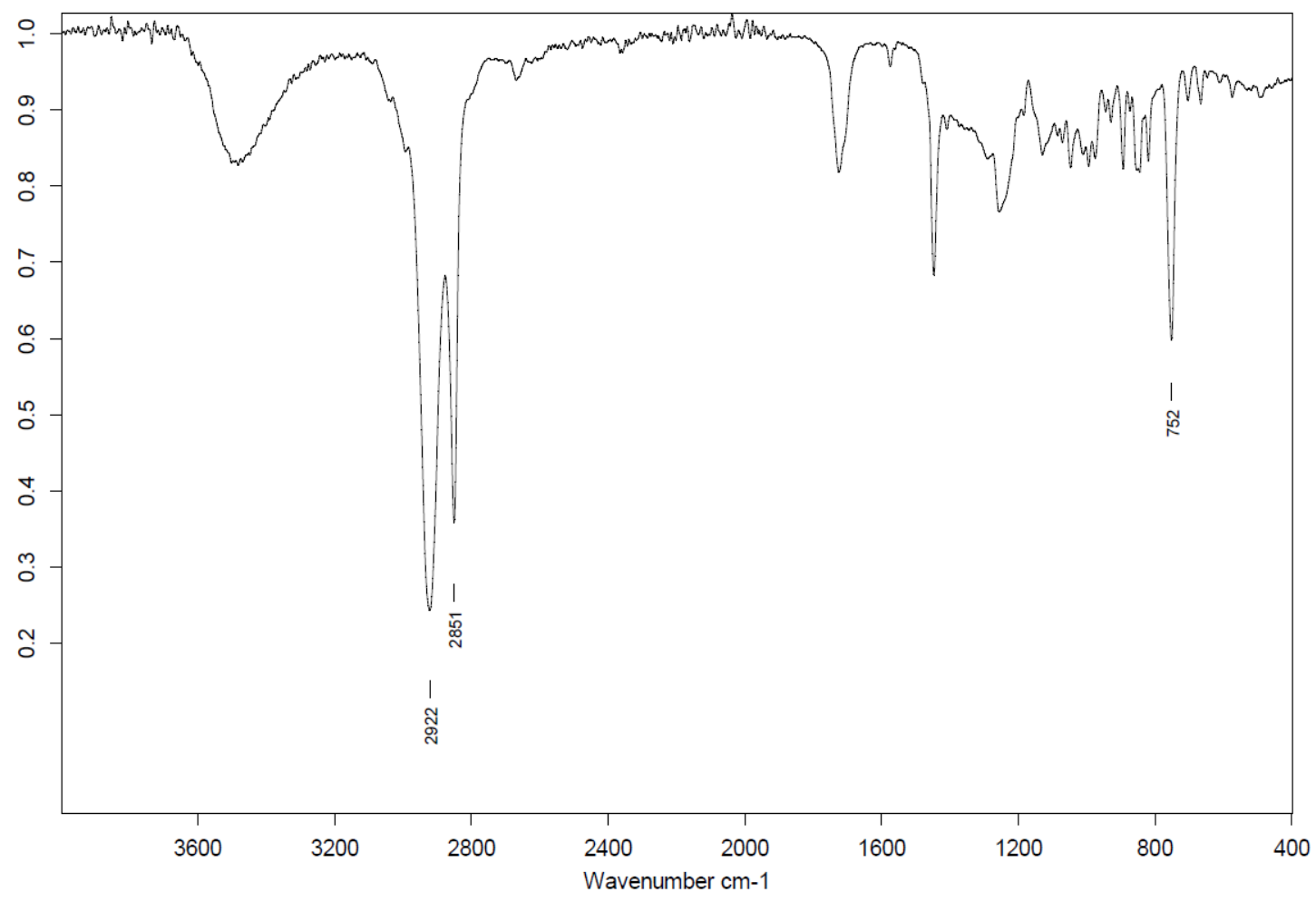



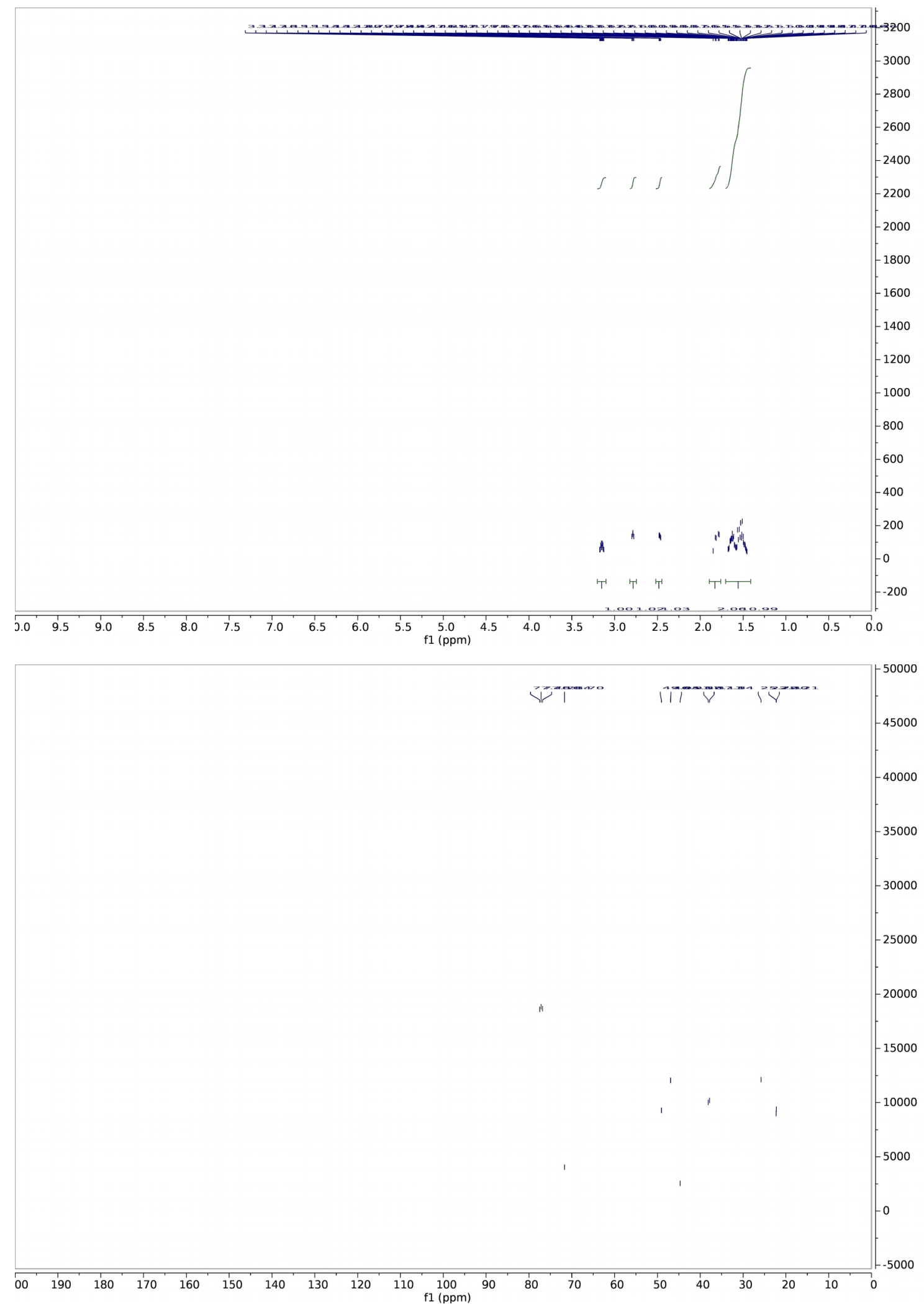


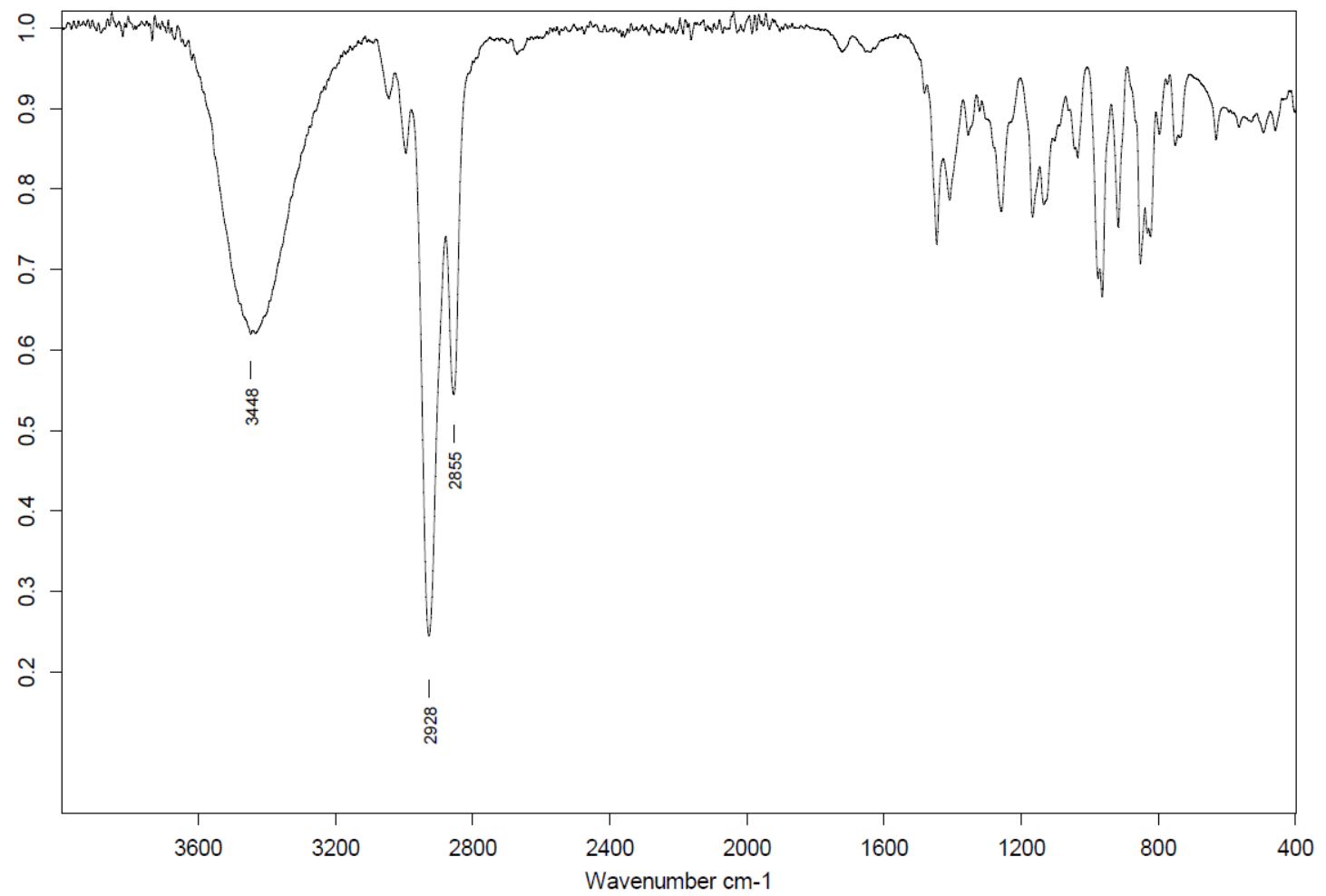




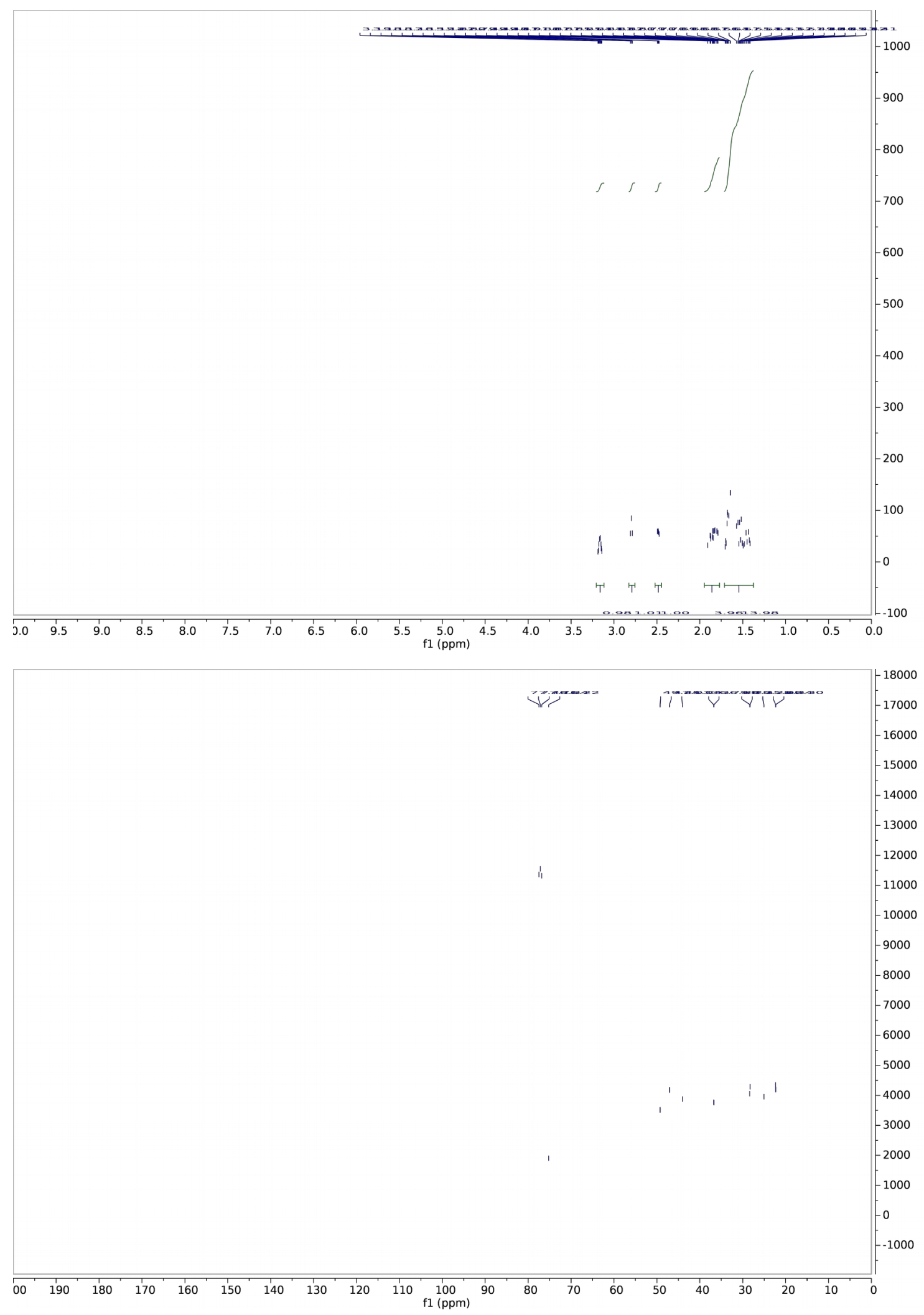




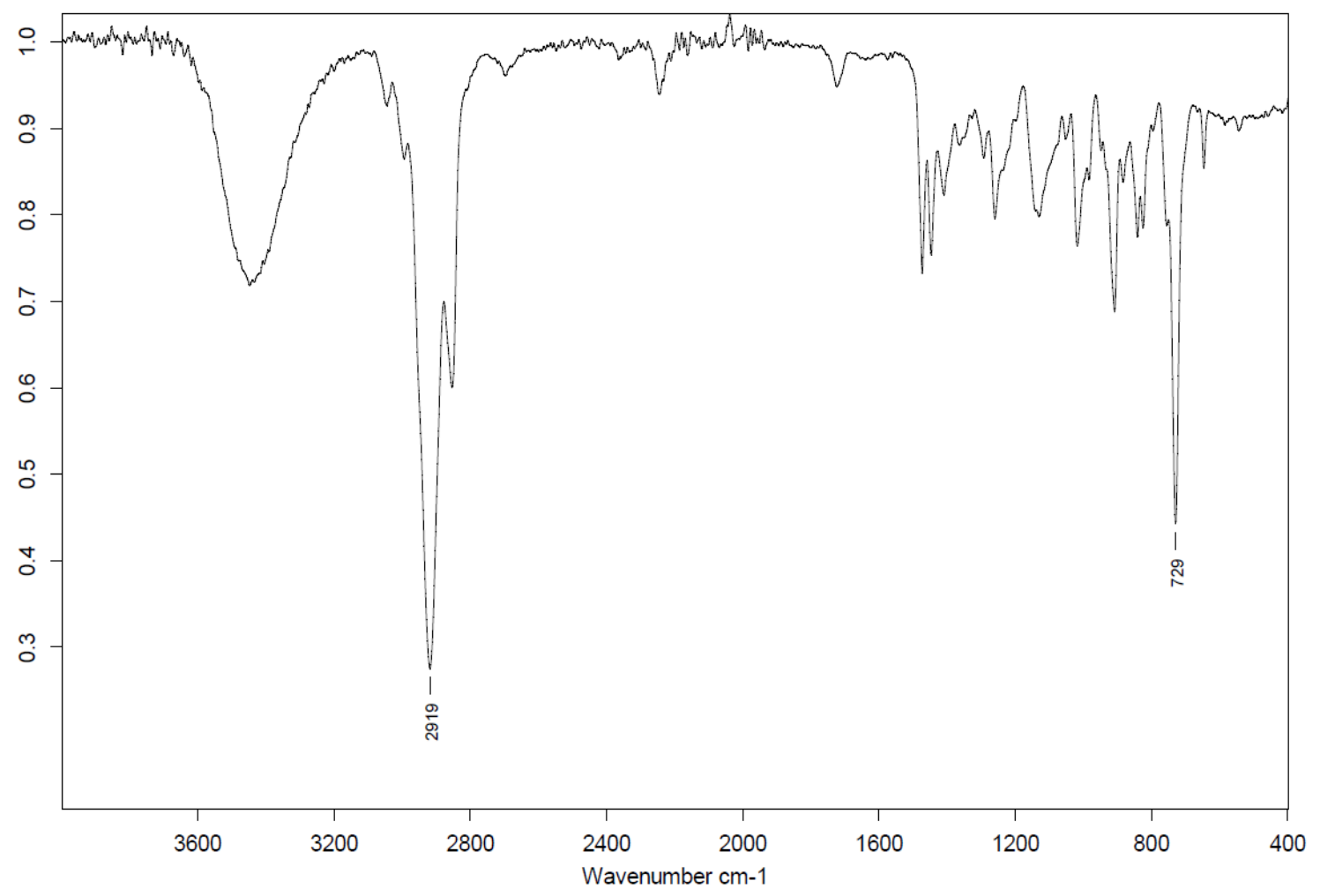




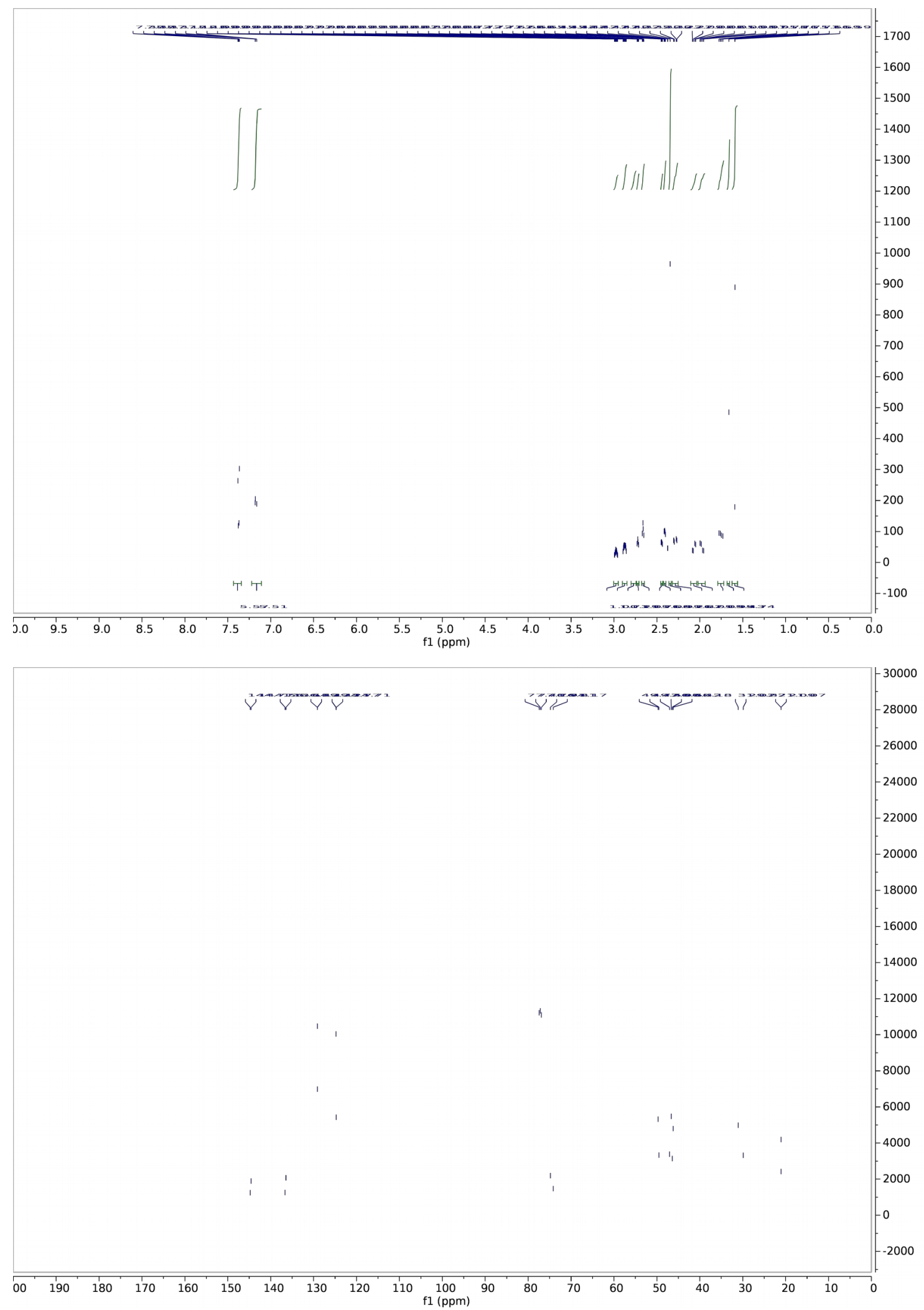




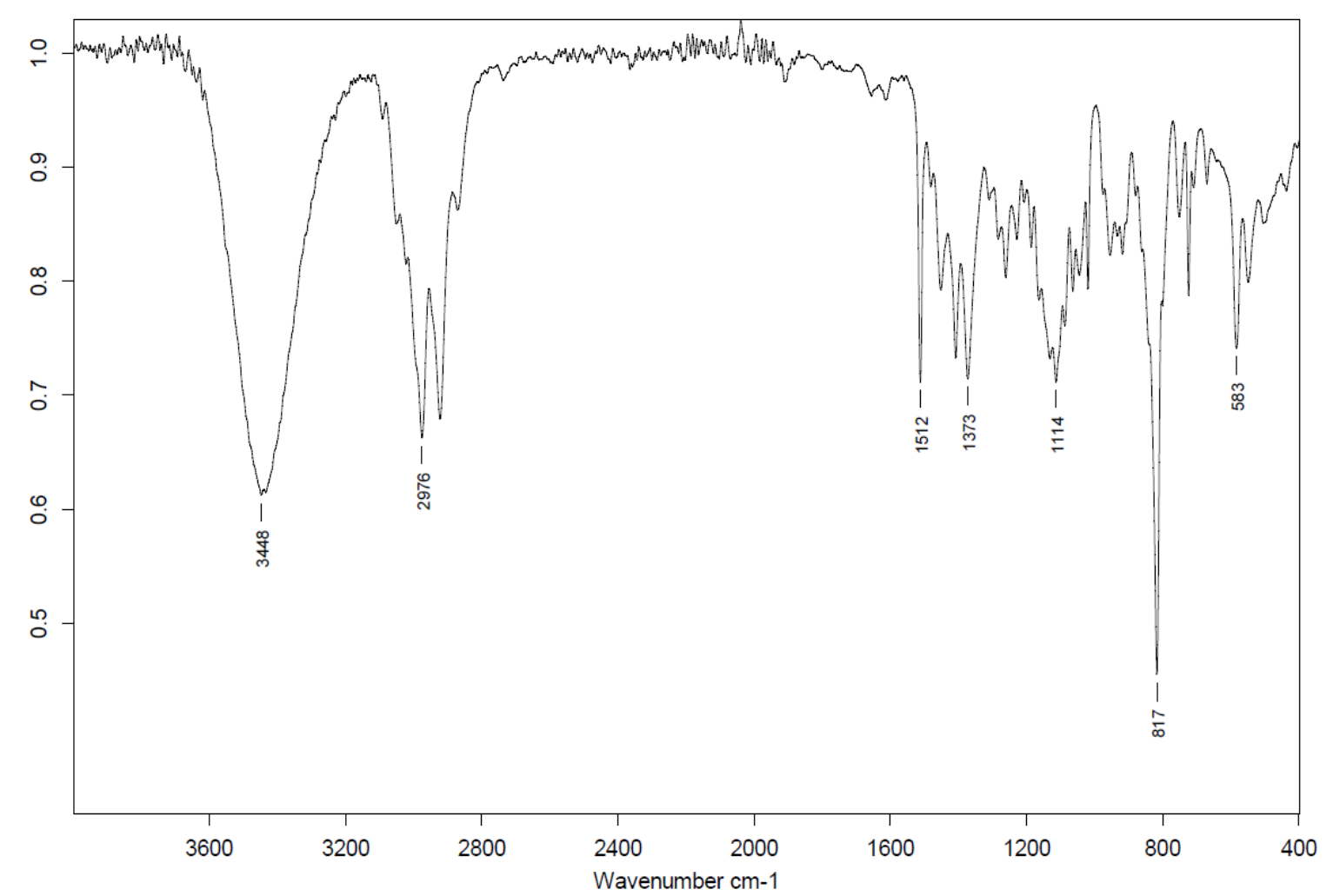



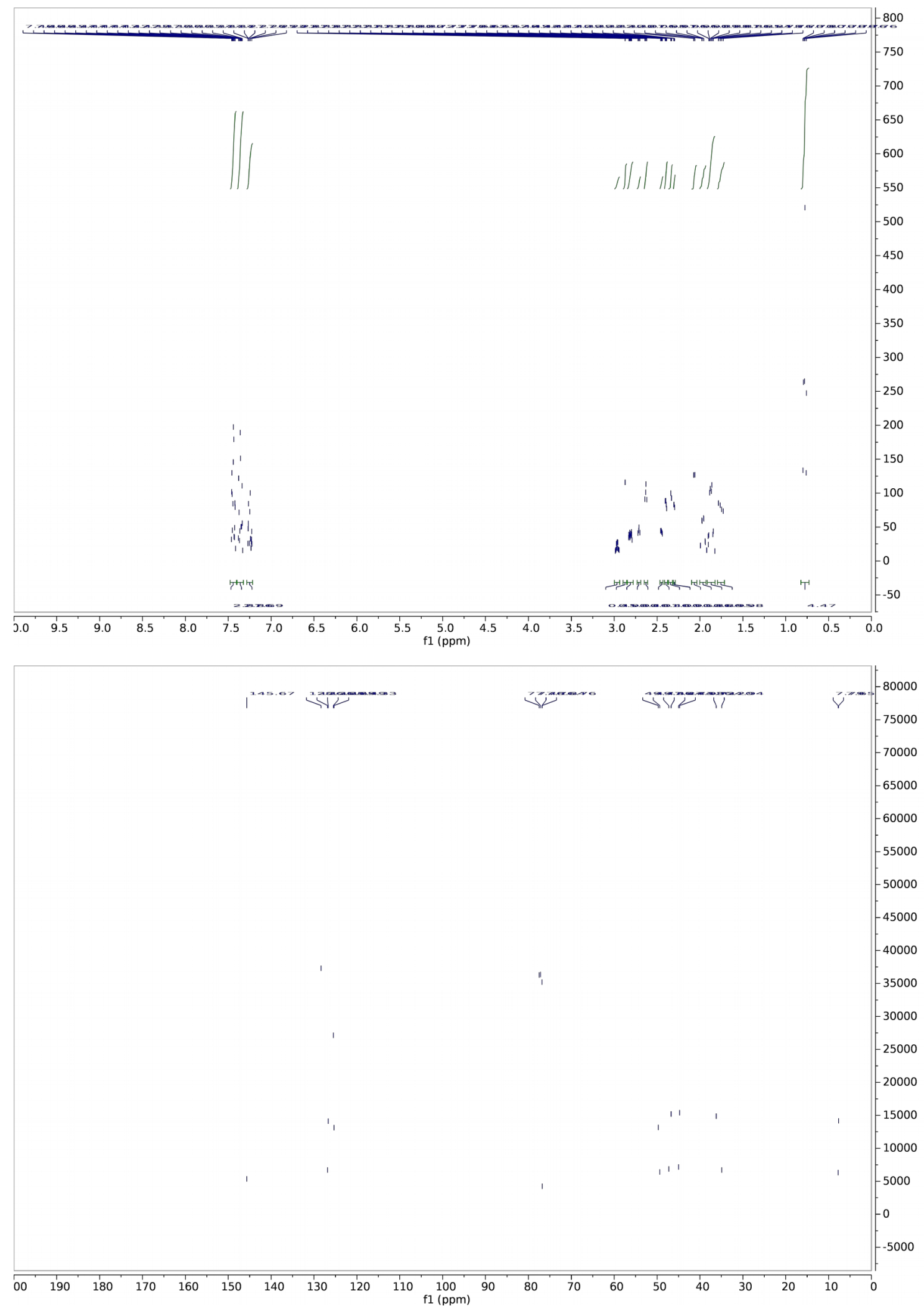


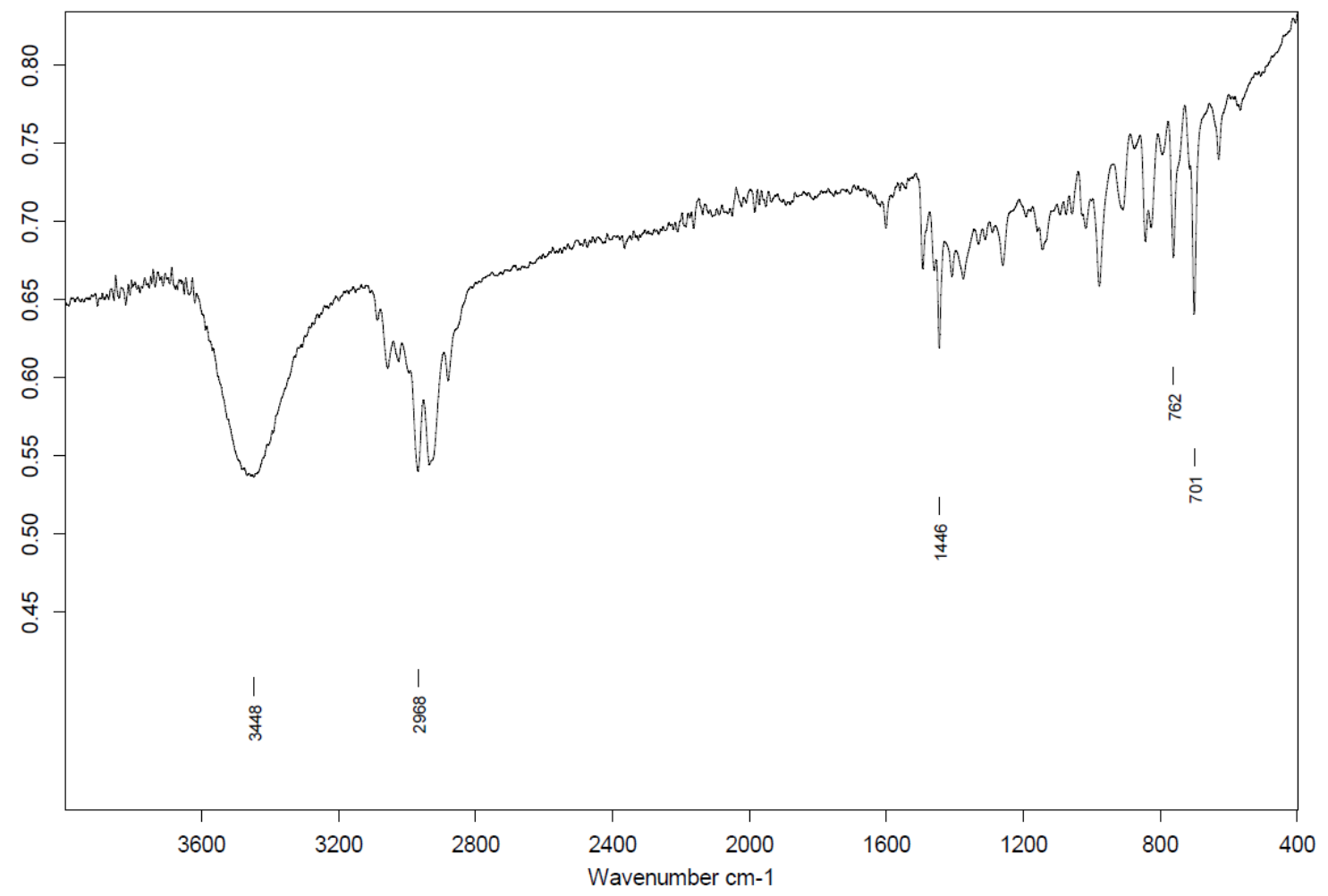




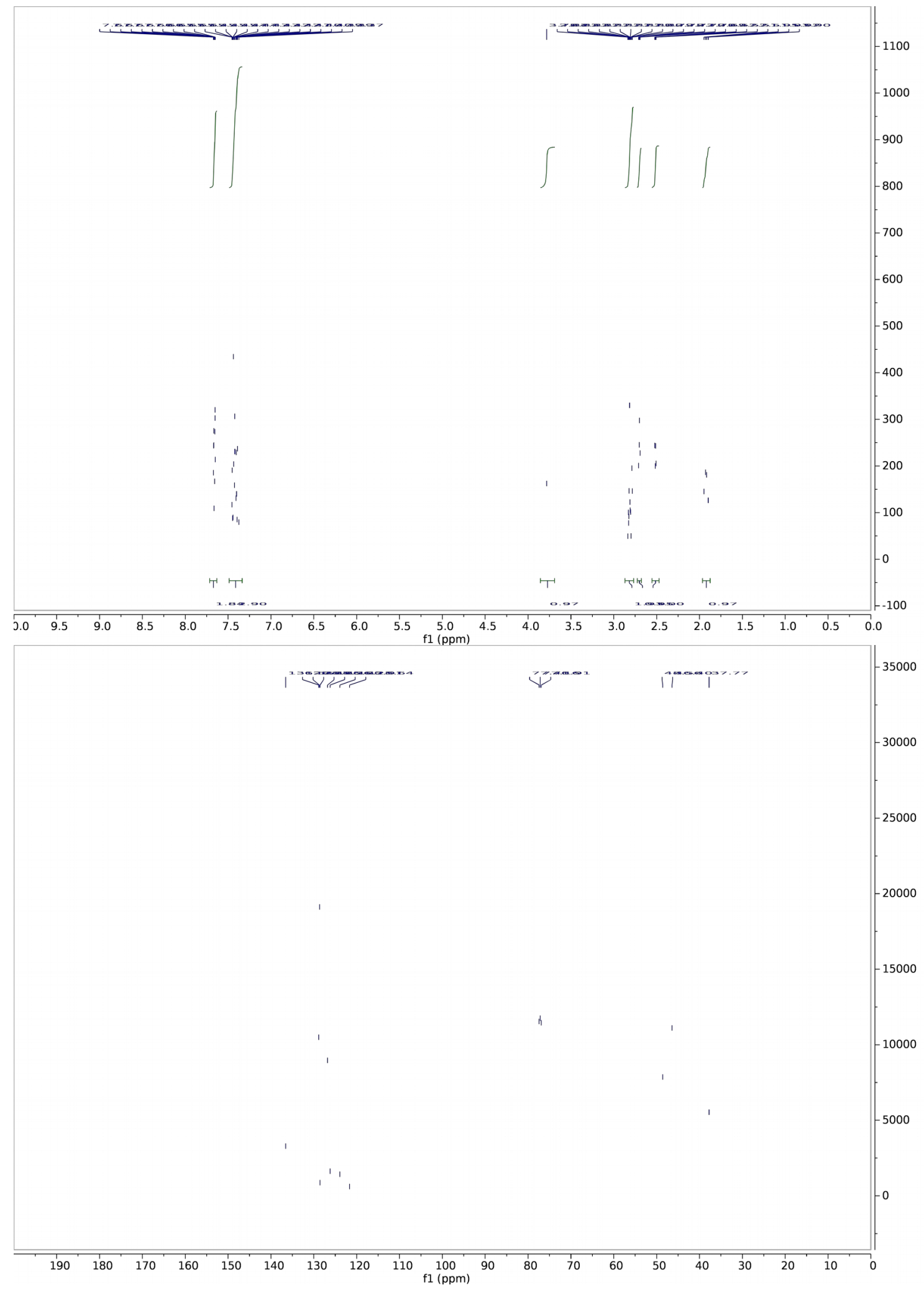



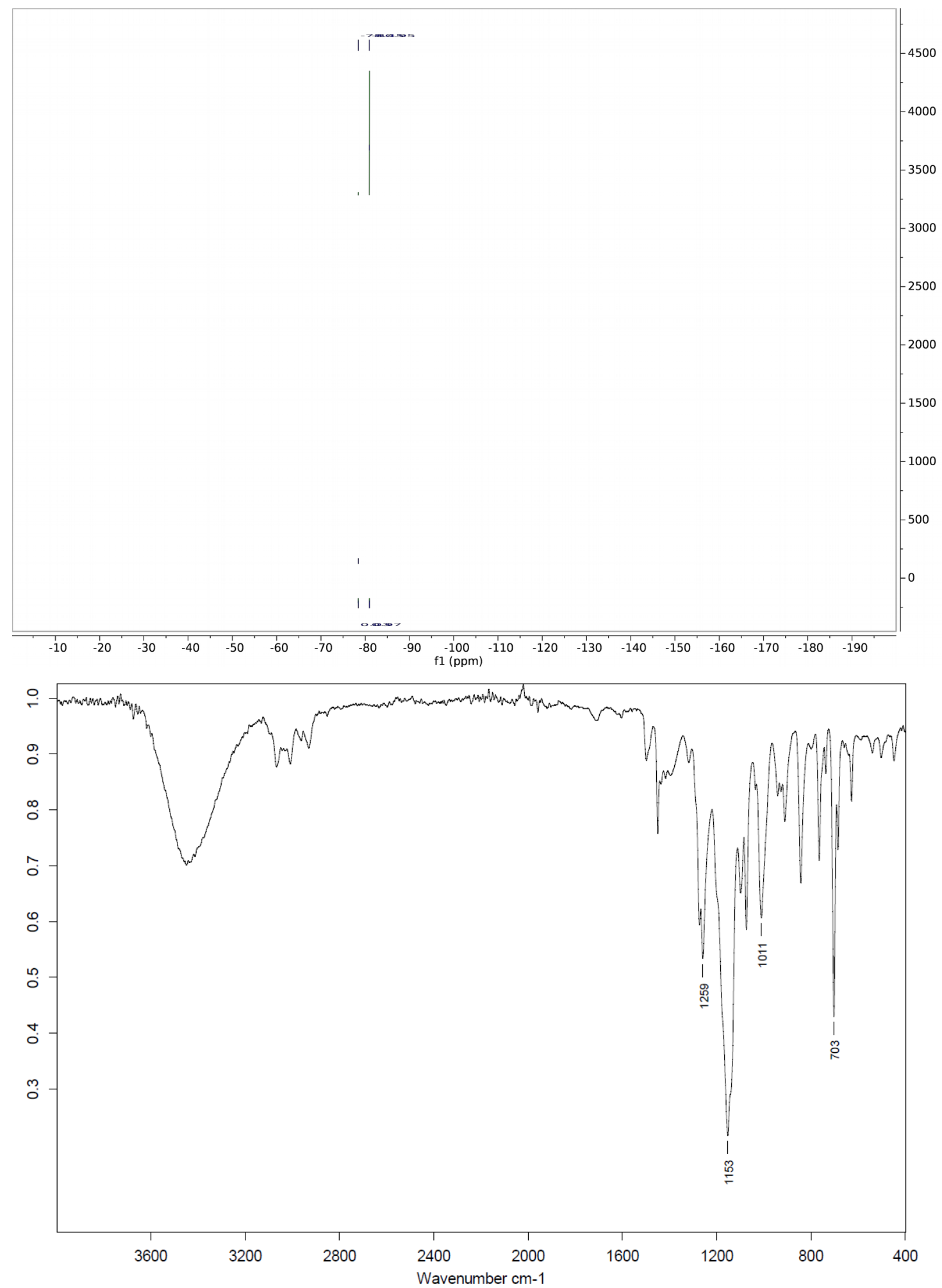


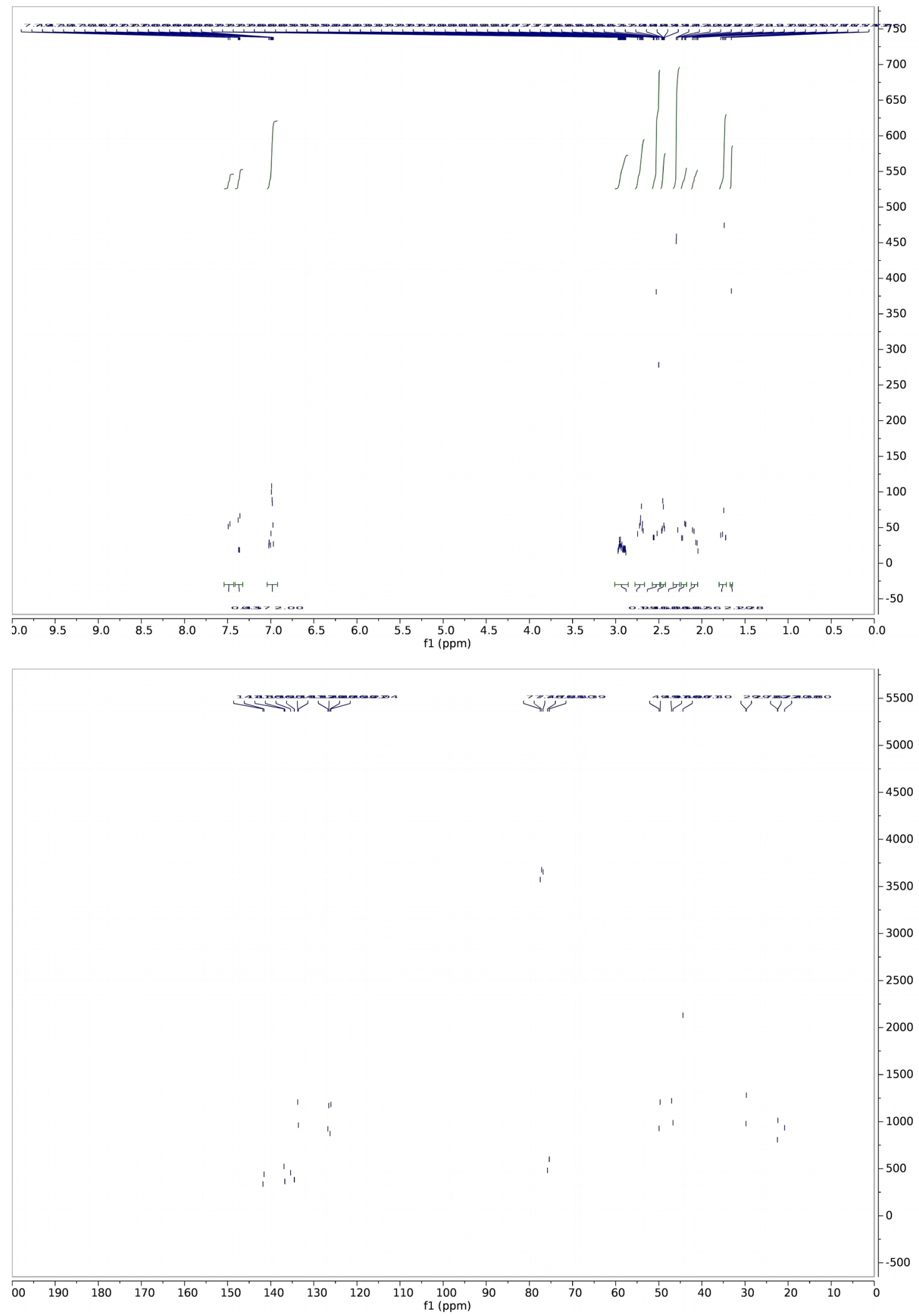




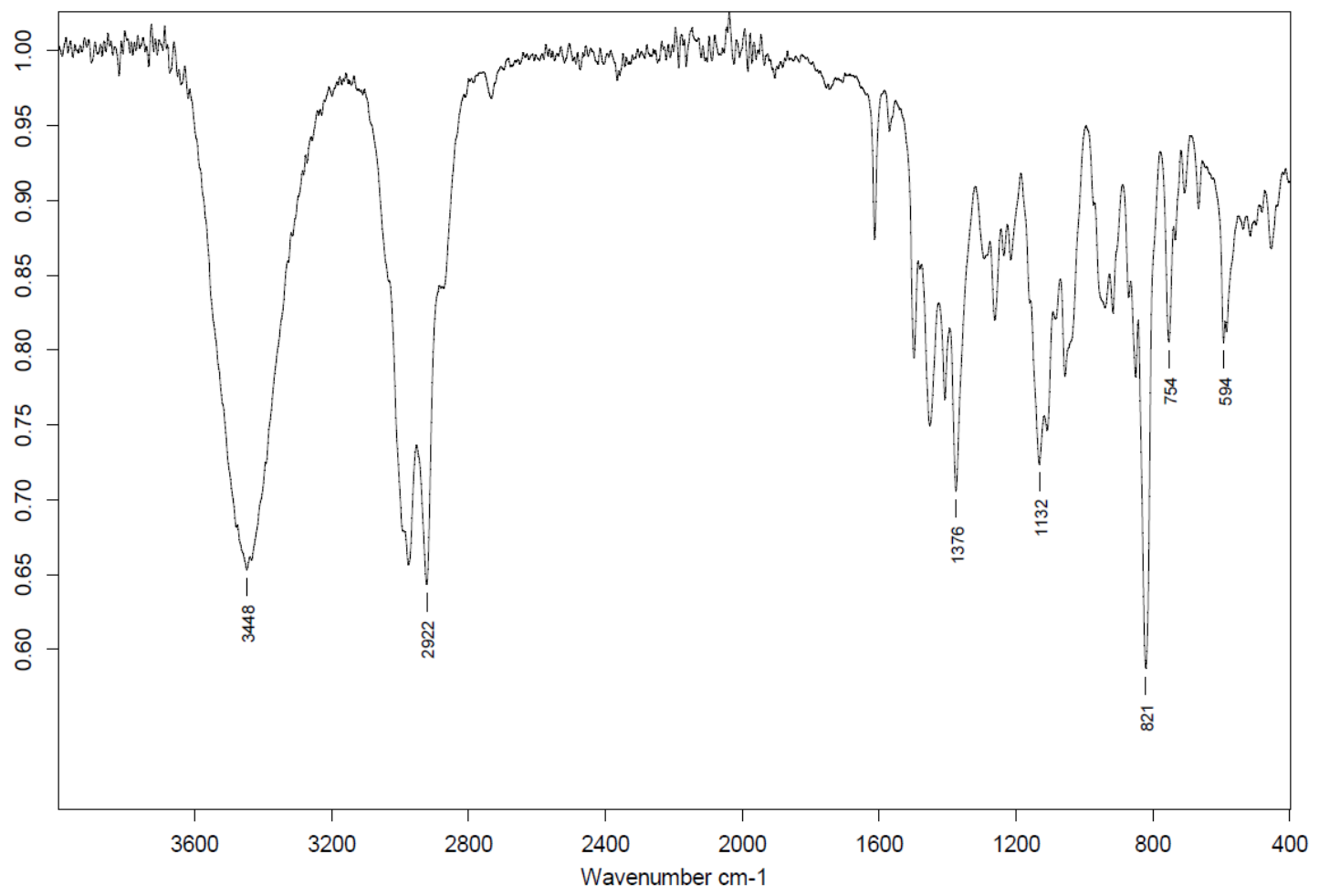



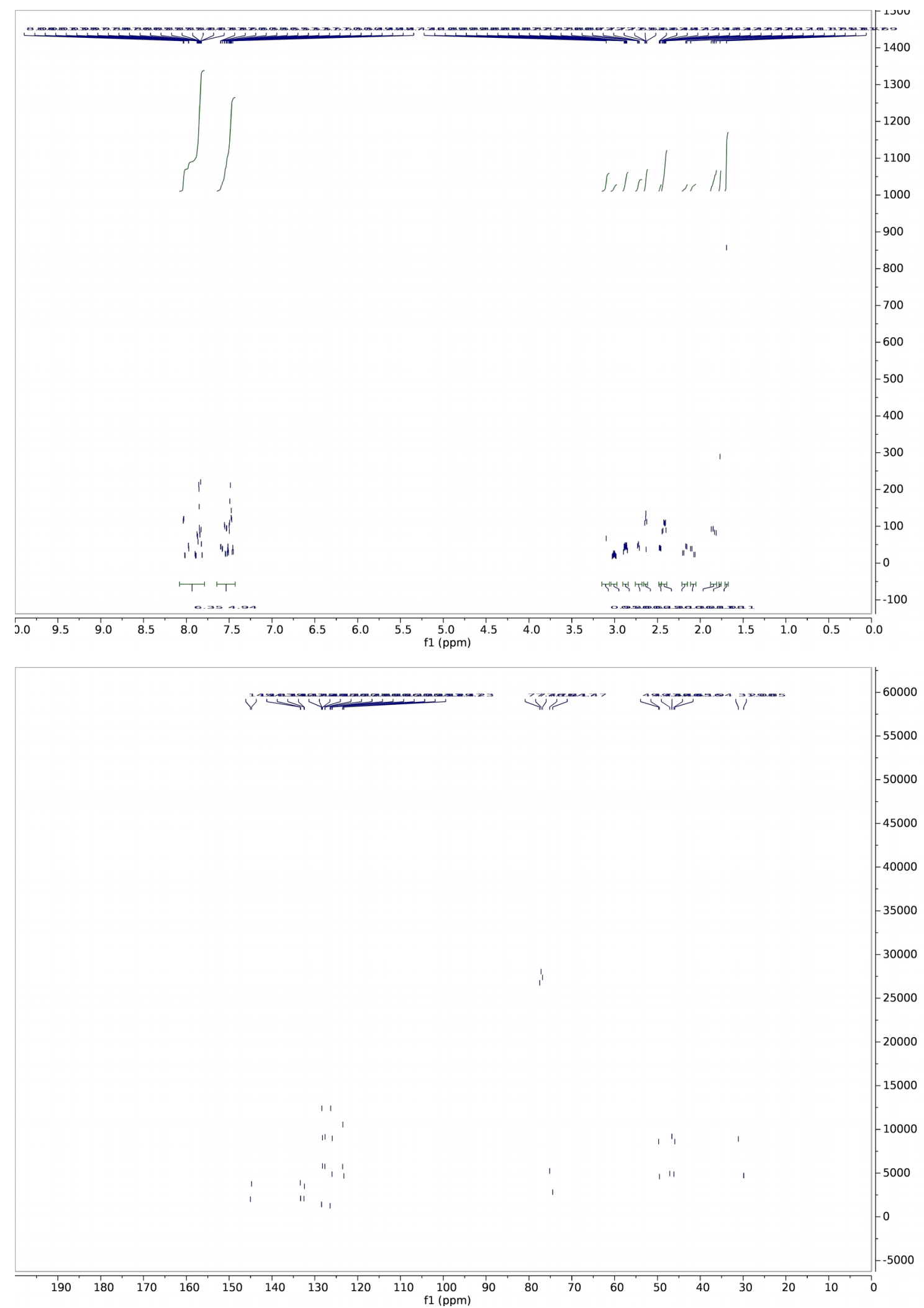


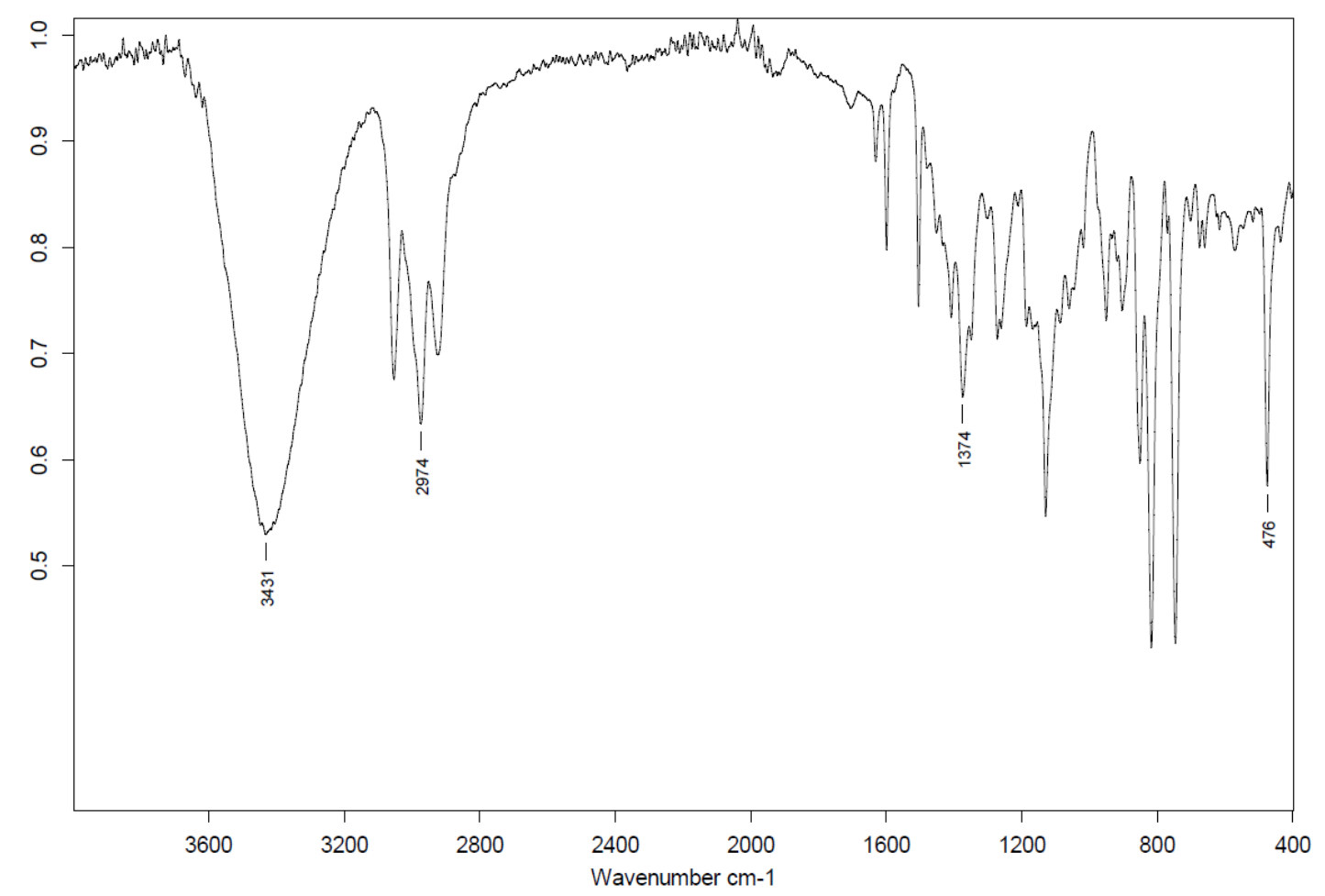




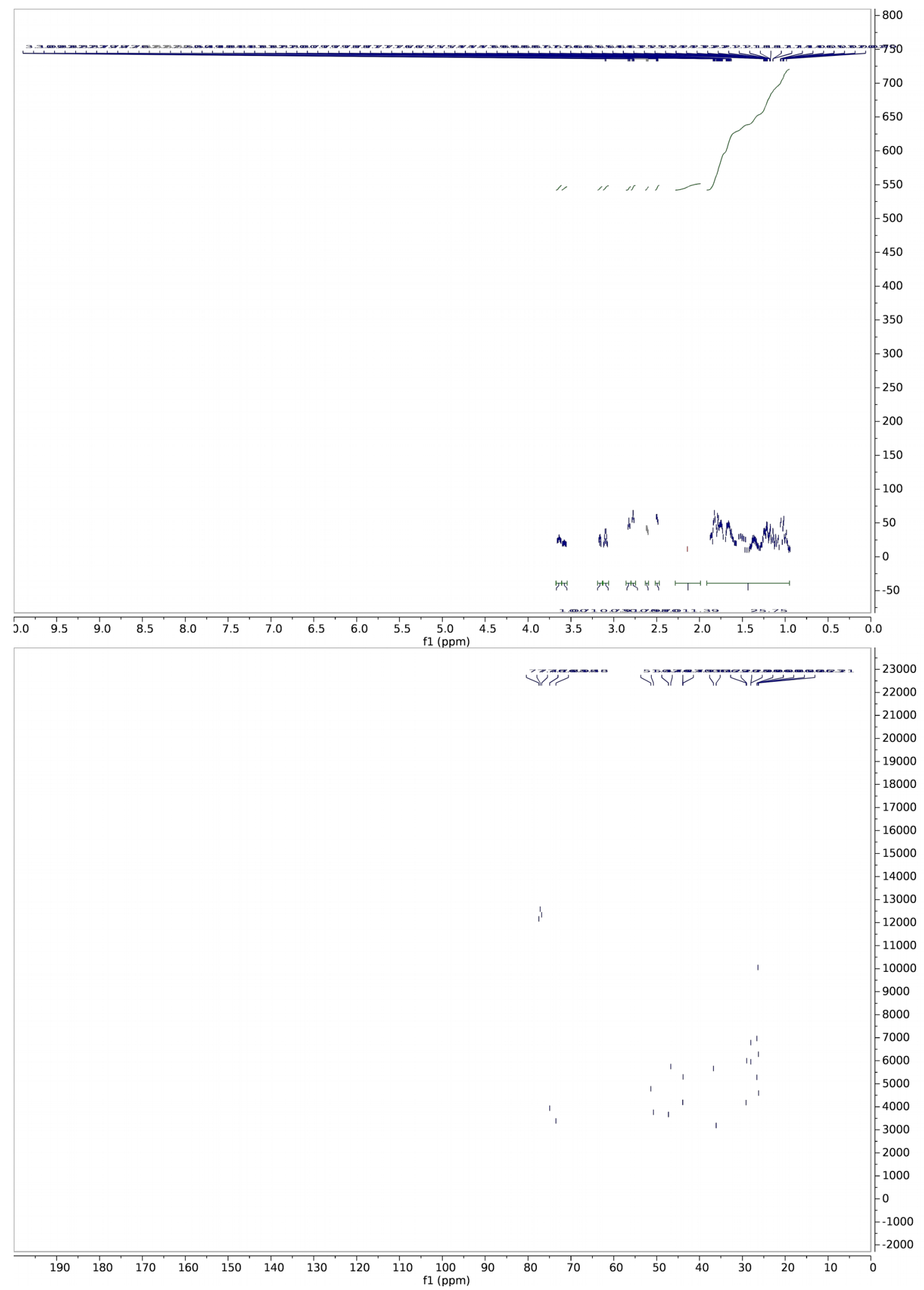




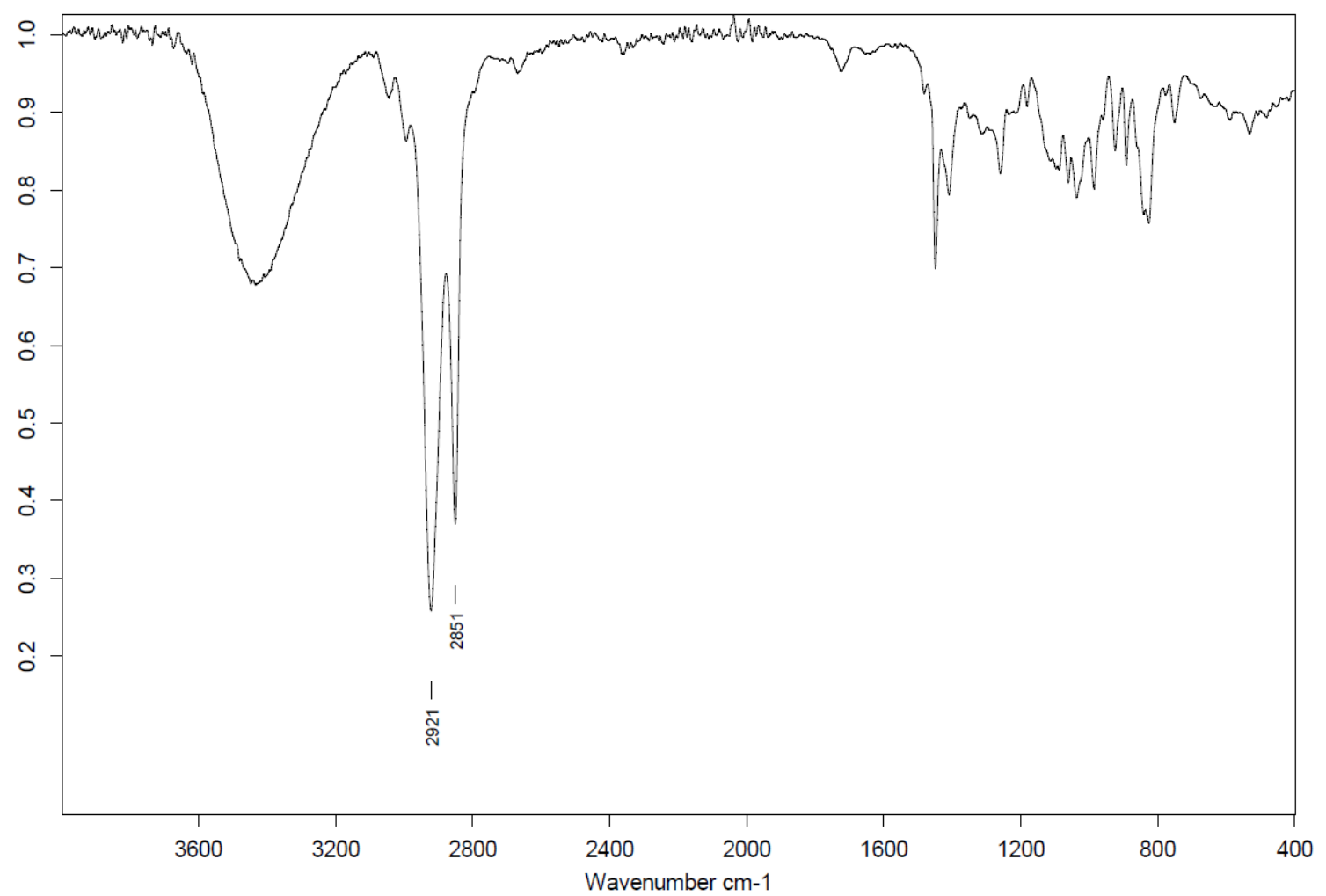



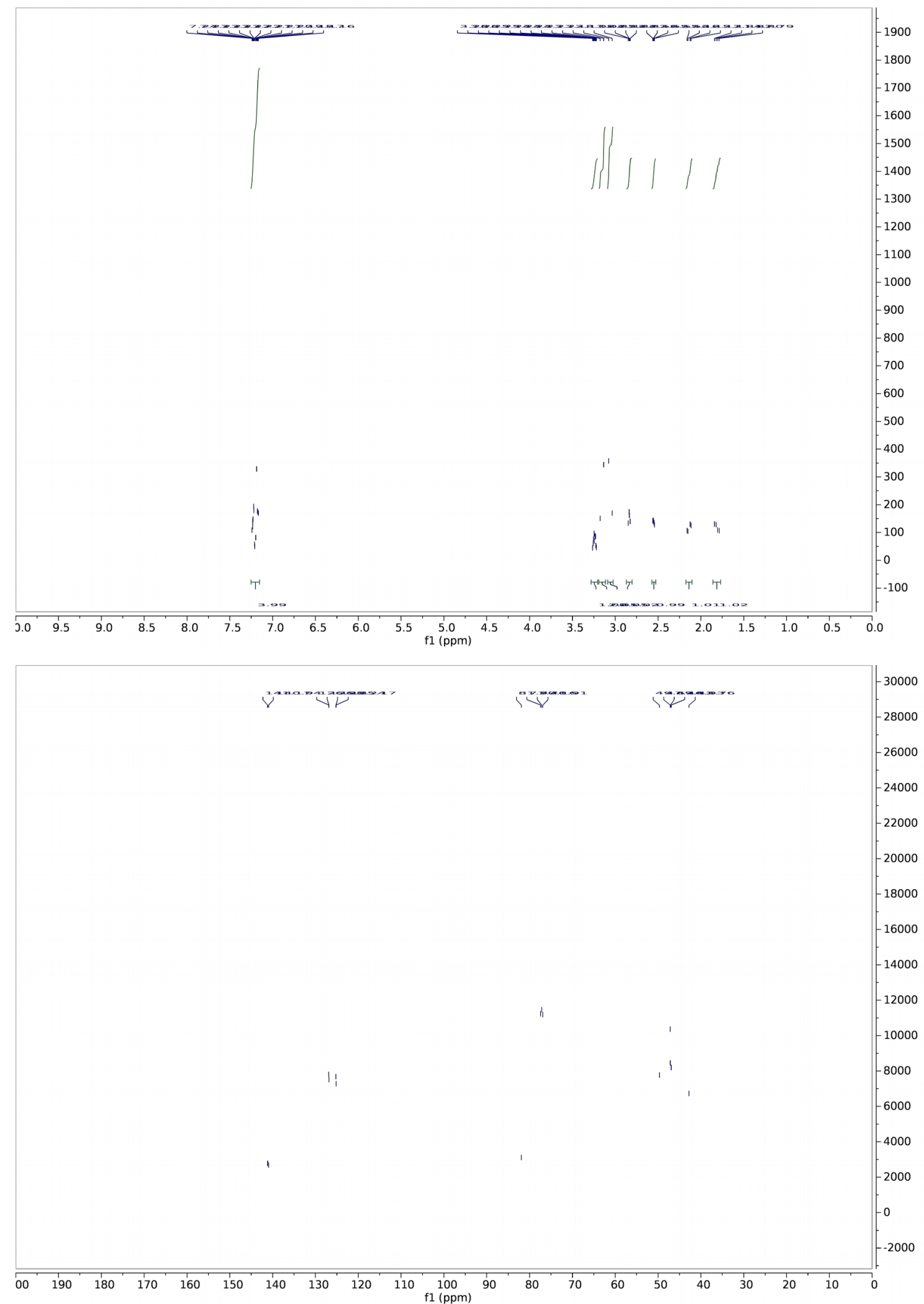


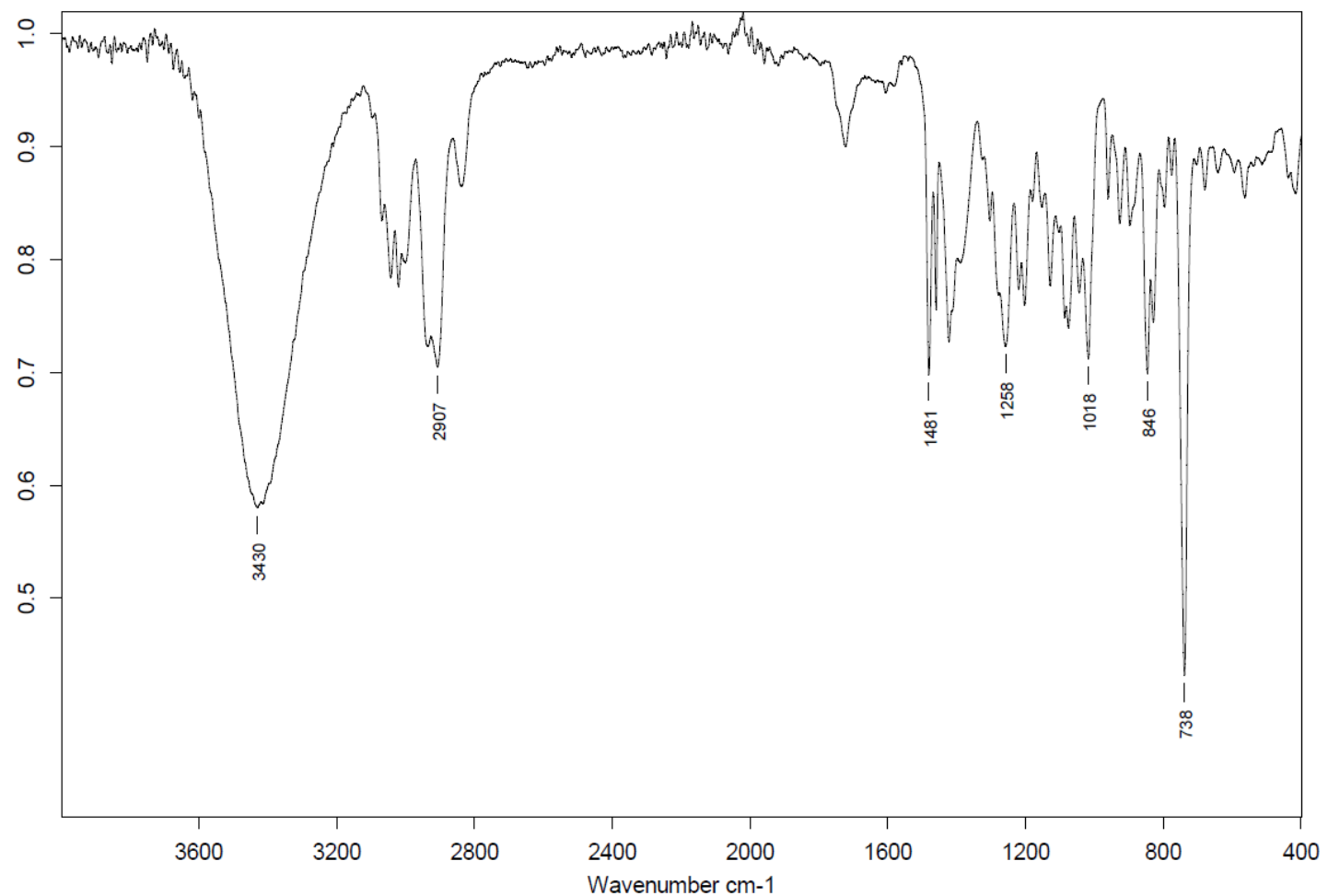




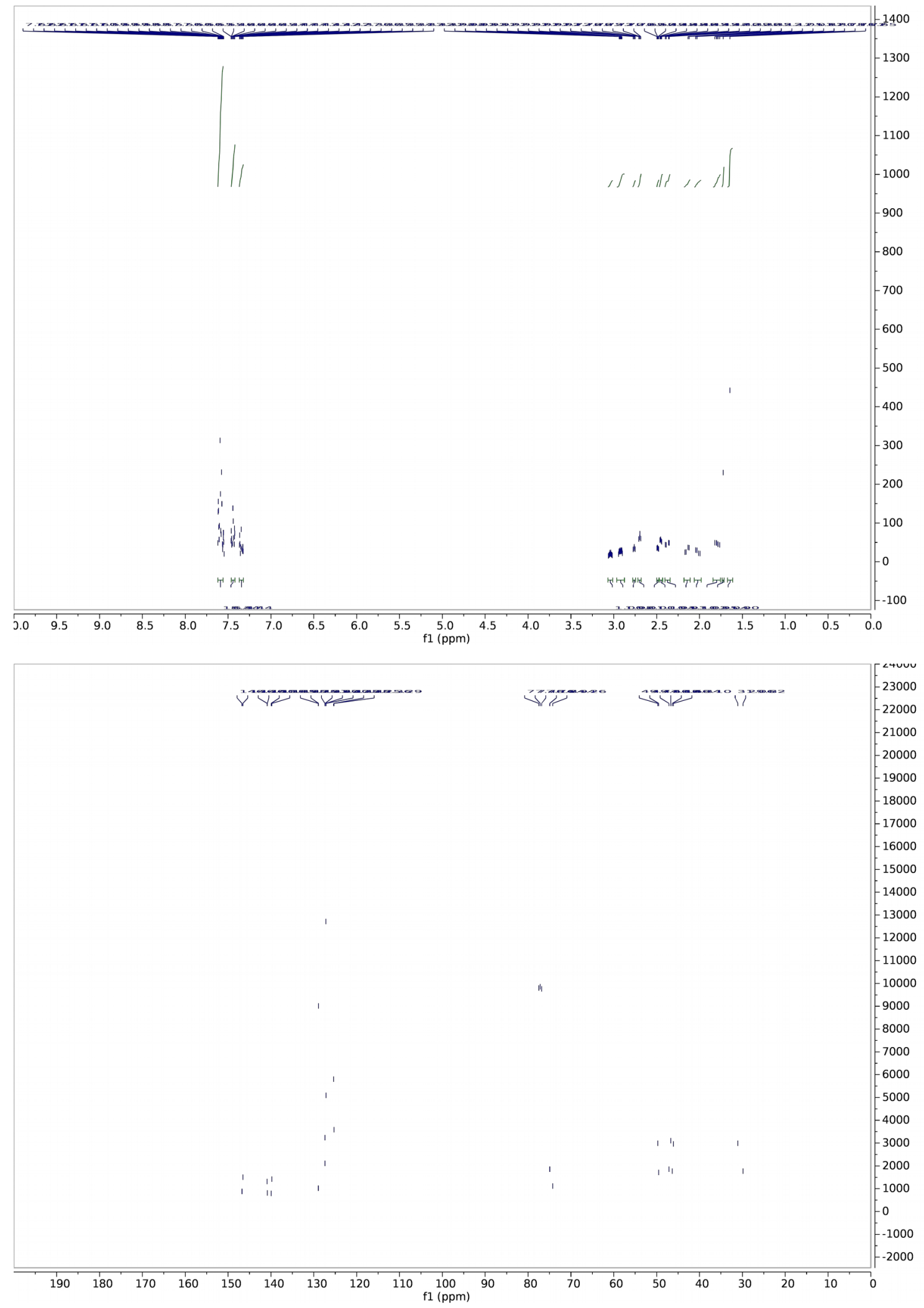




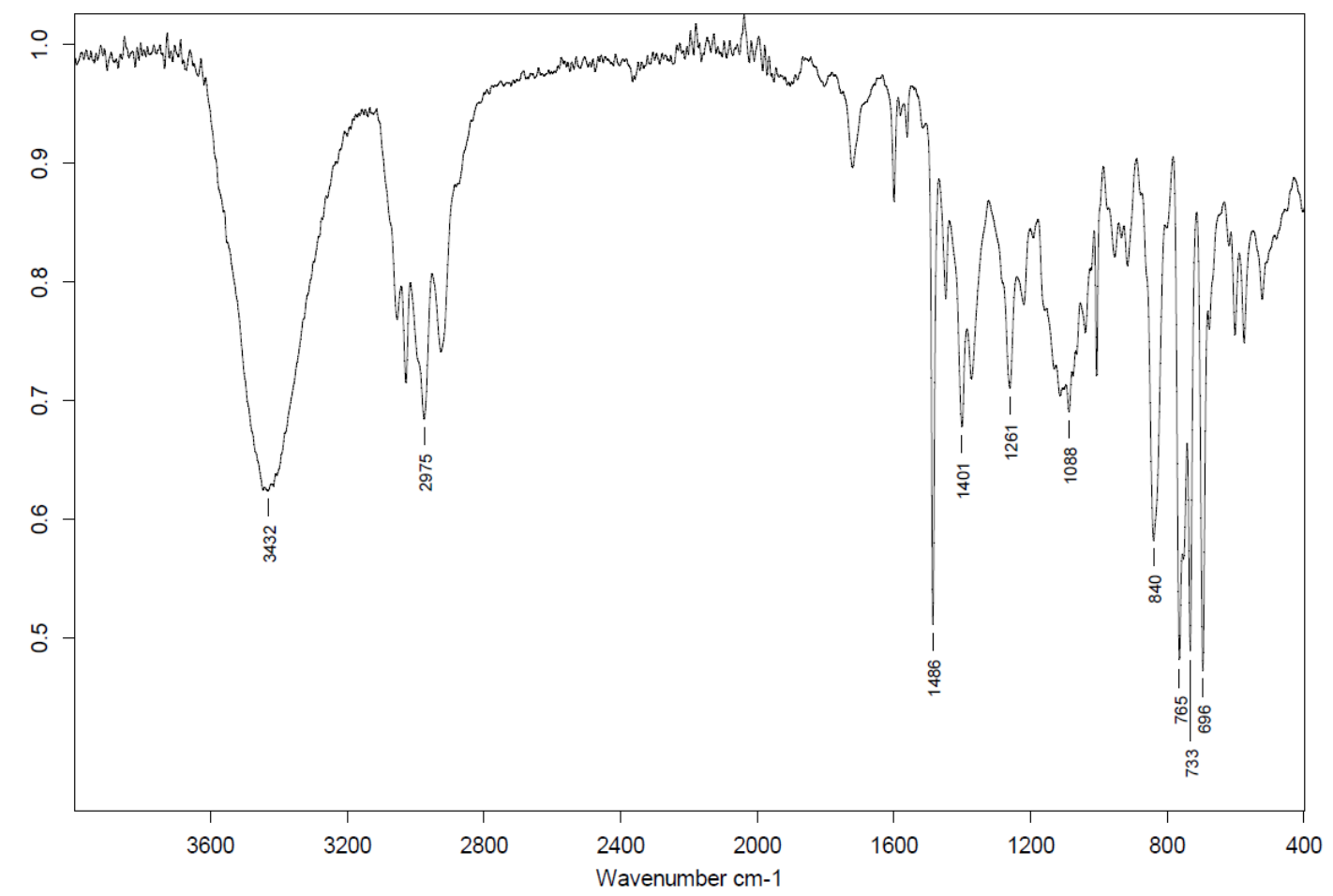



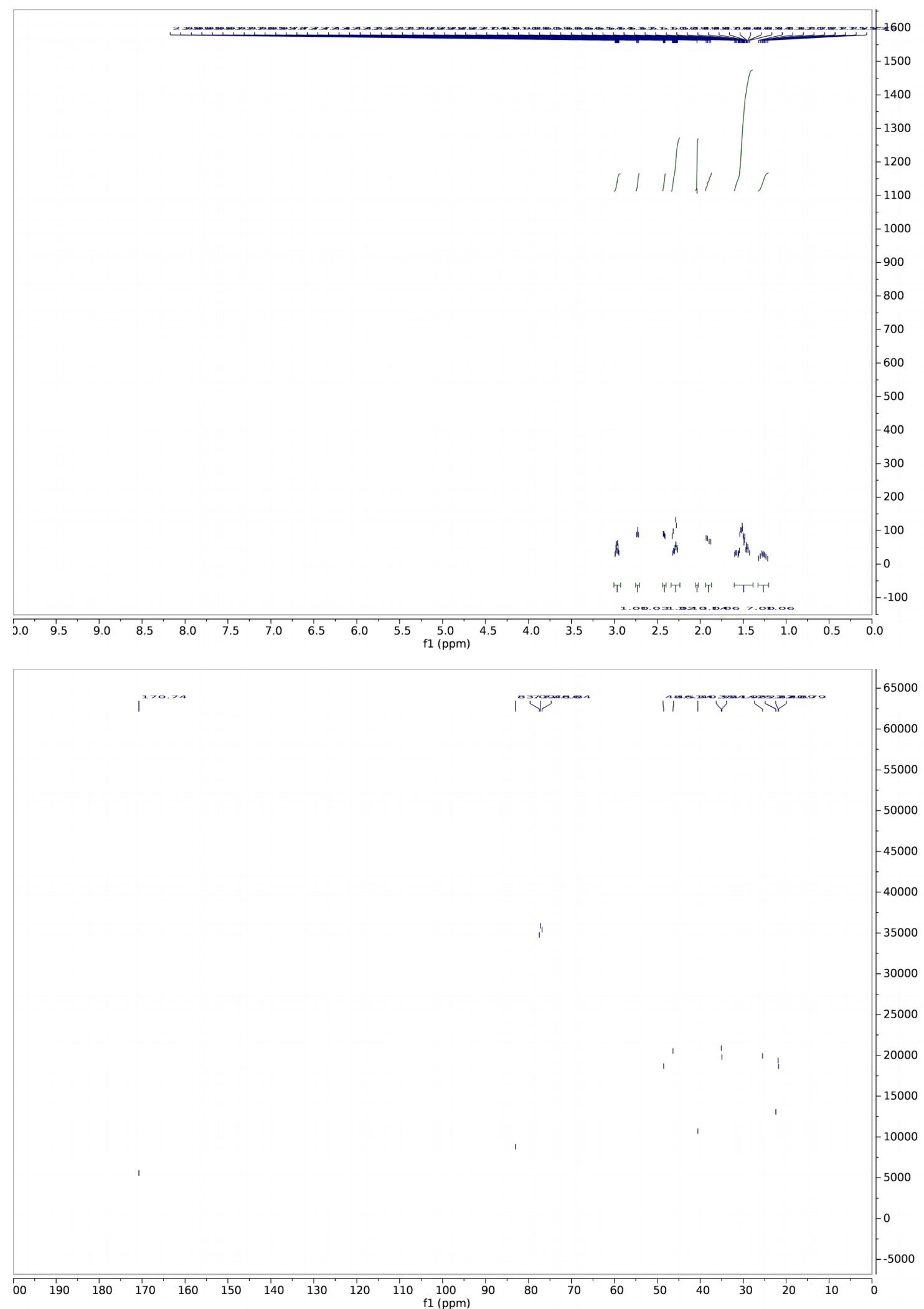


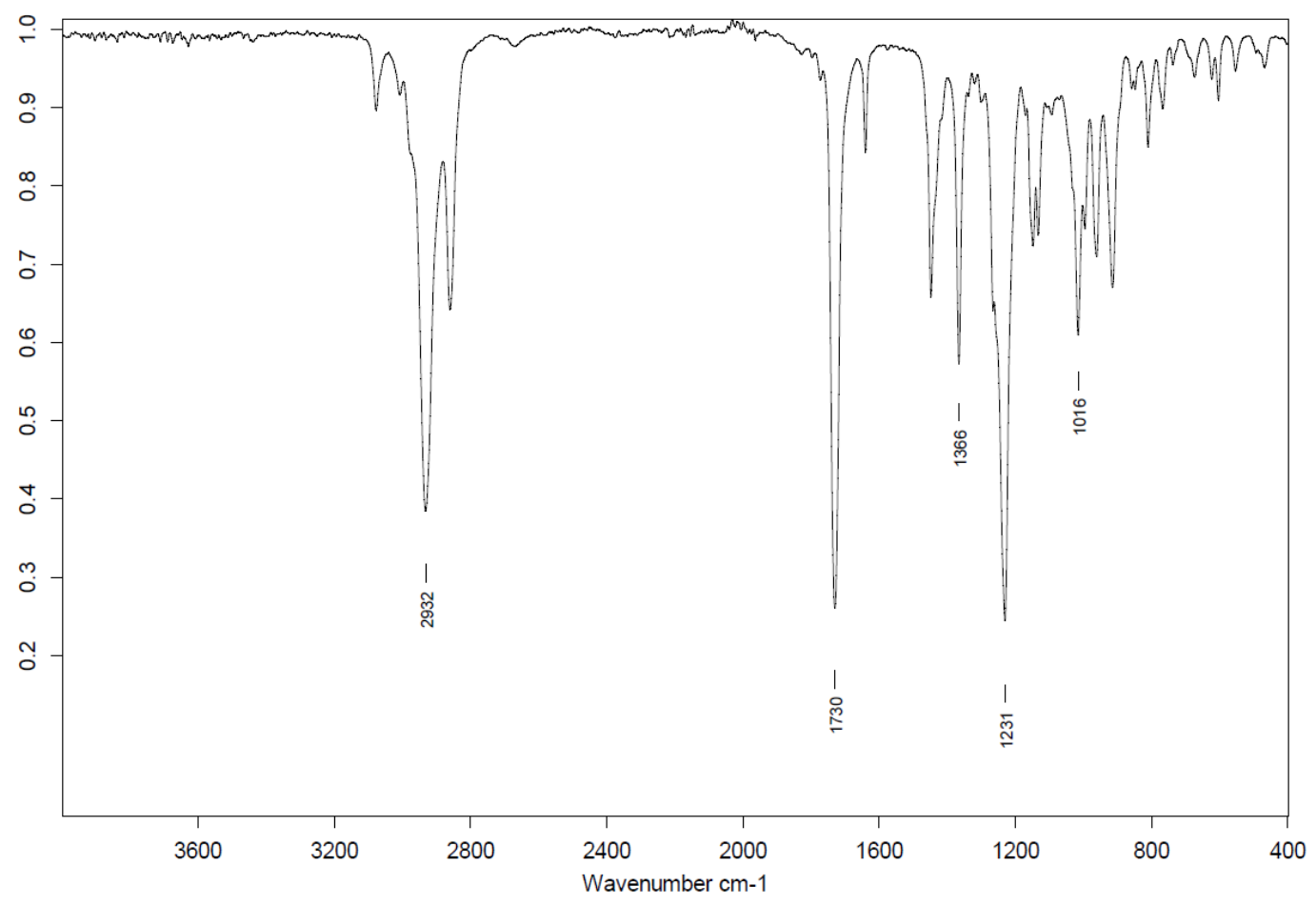


Spectra for 5-membered cyclic carbonate products 1a-1q:

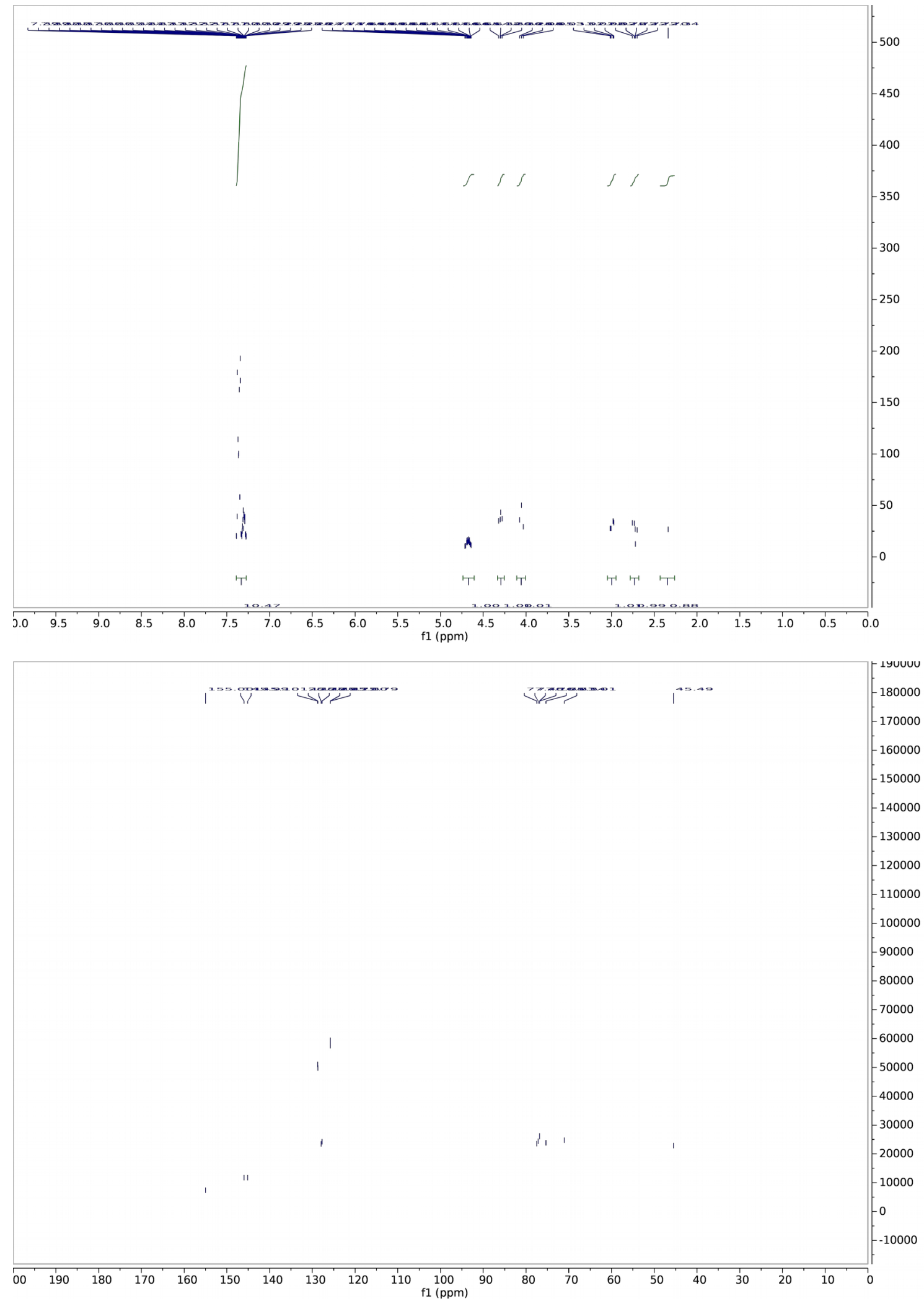




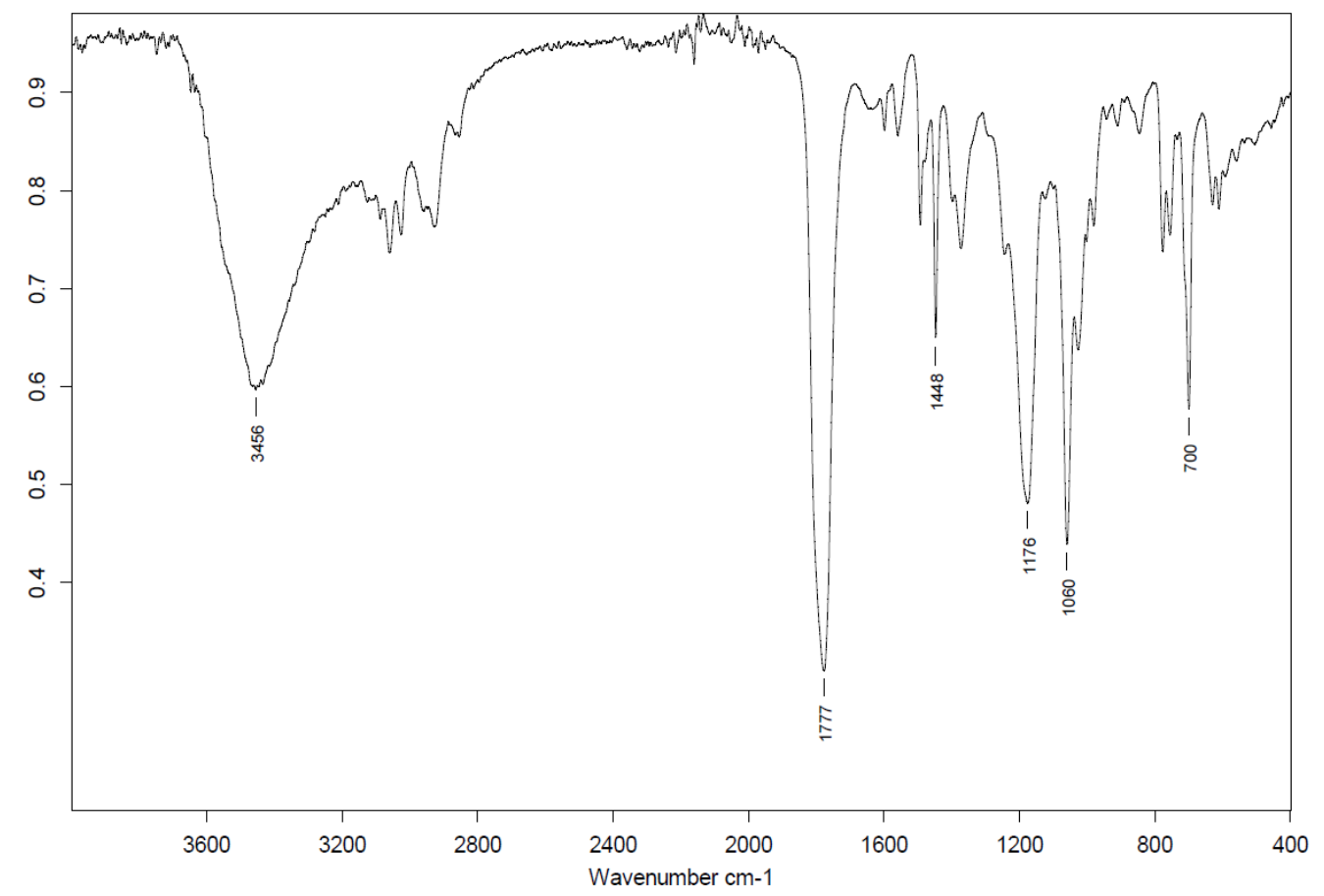



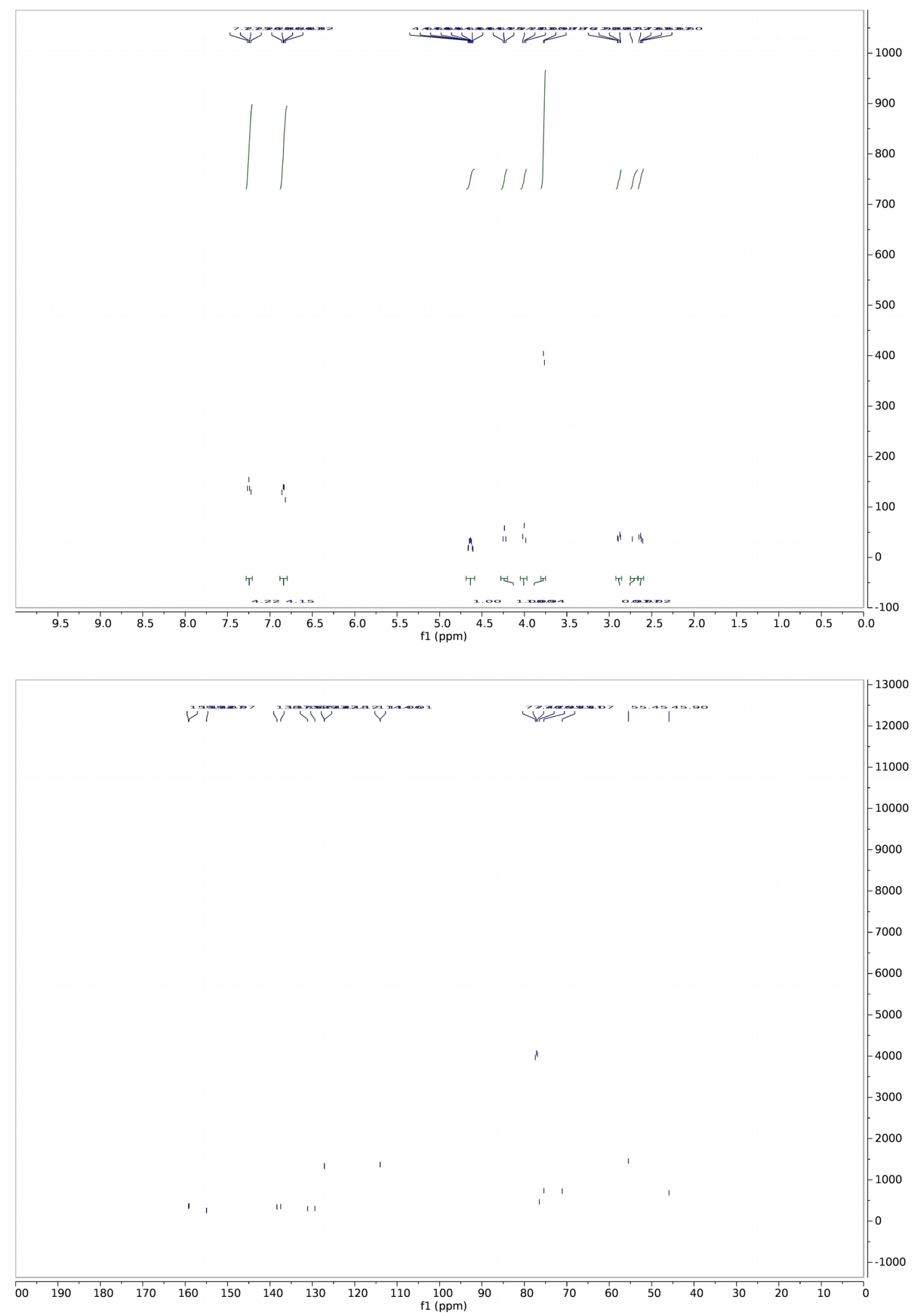


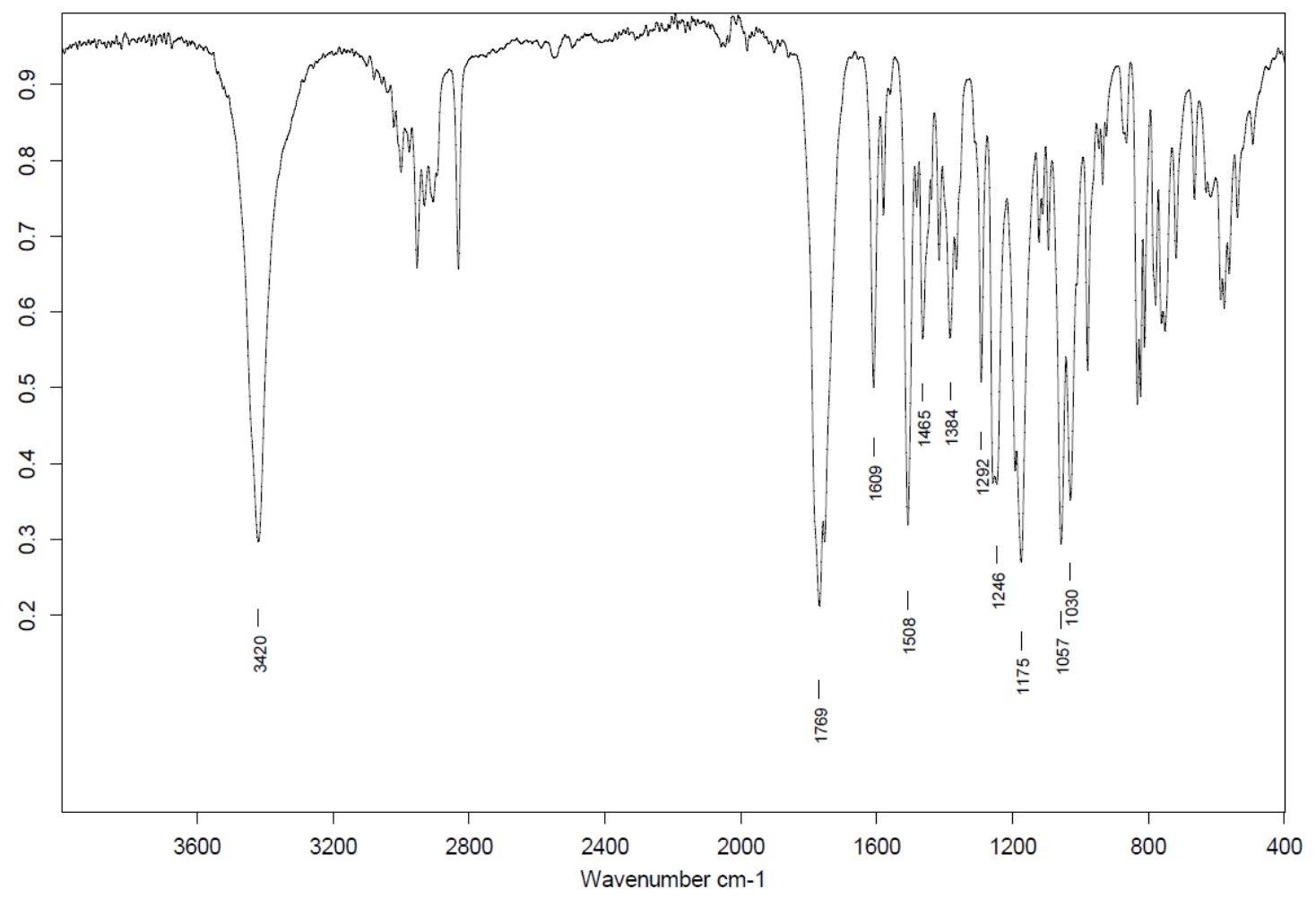



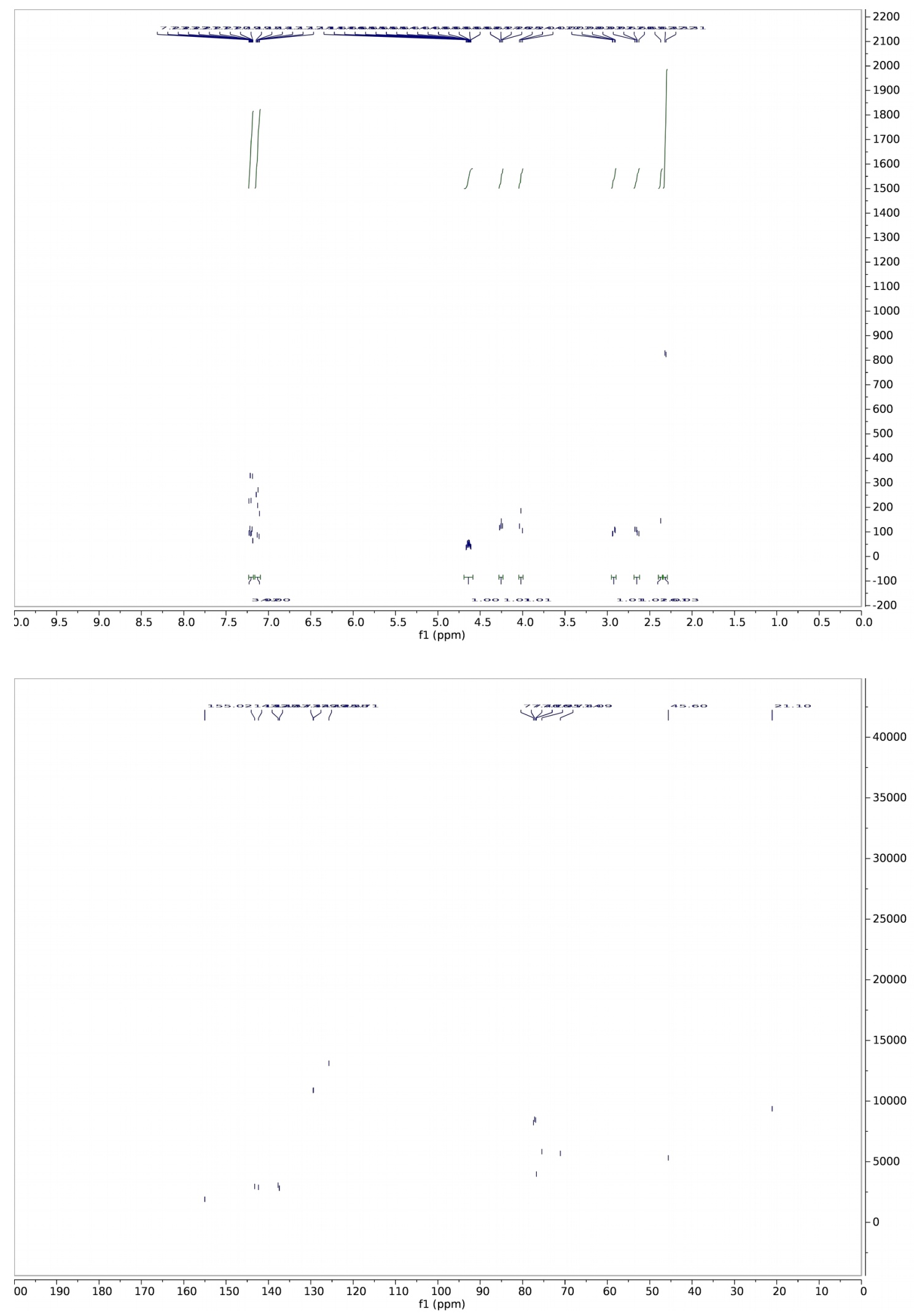


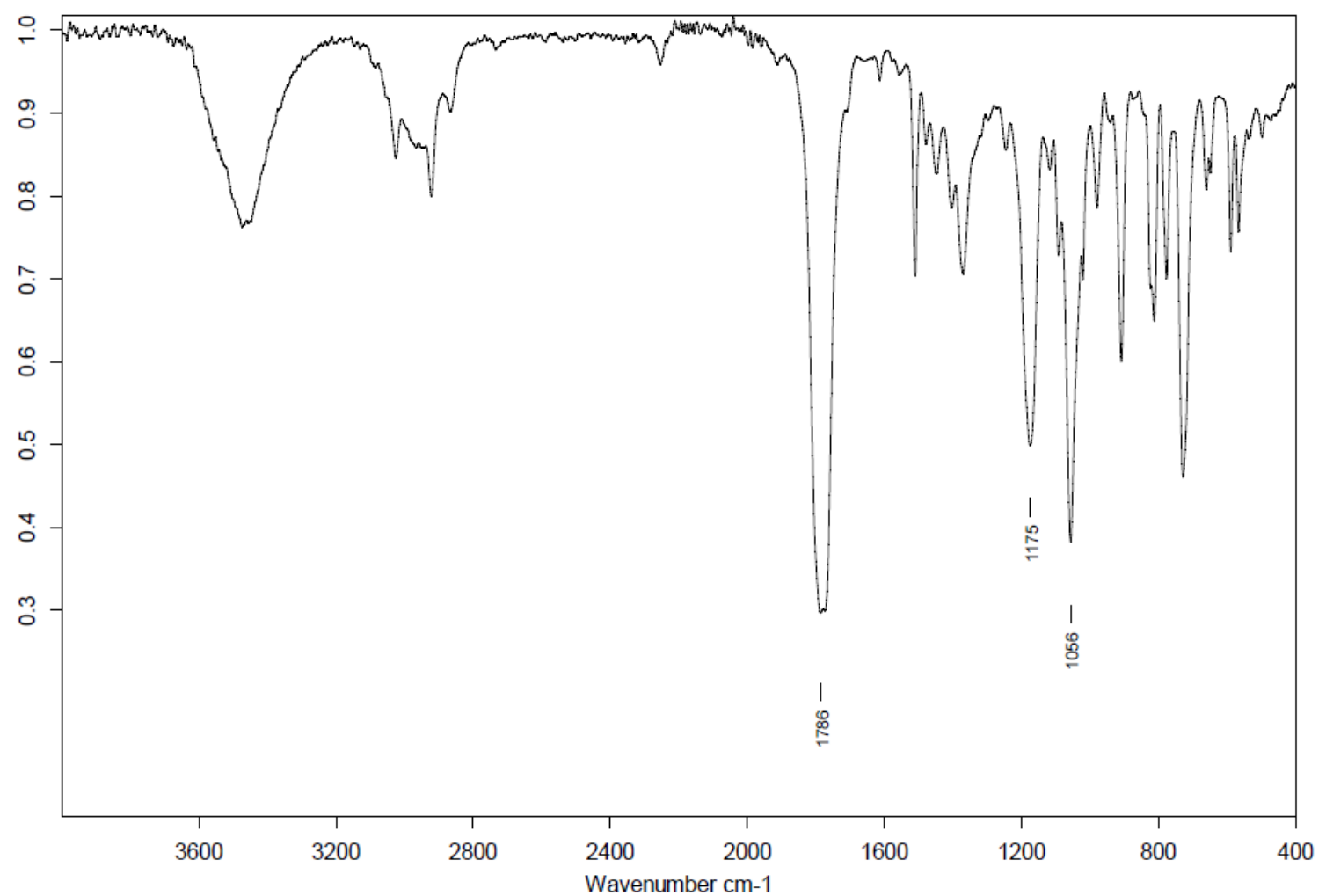



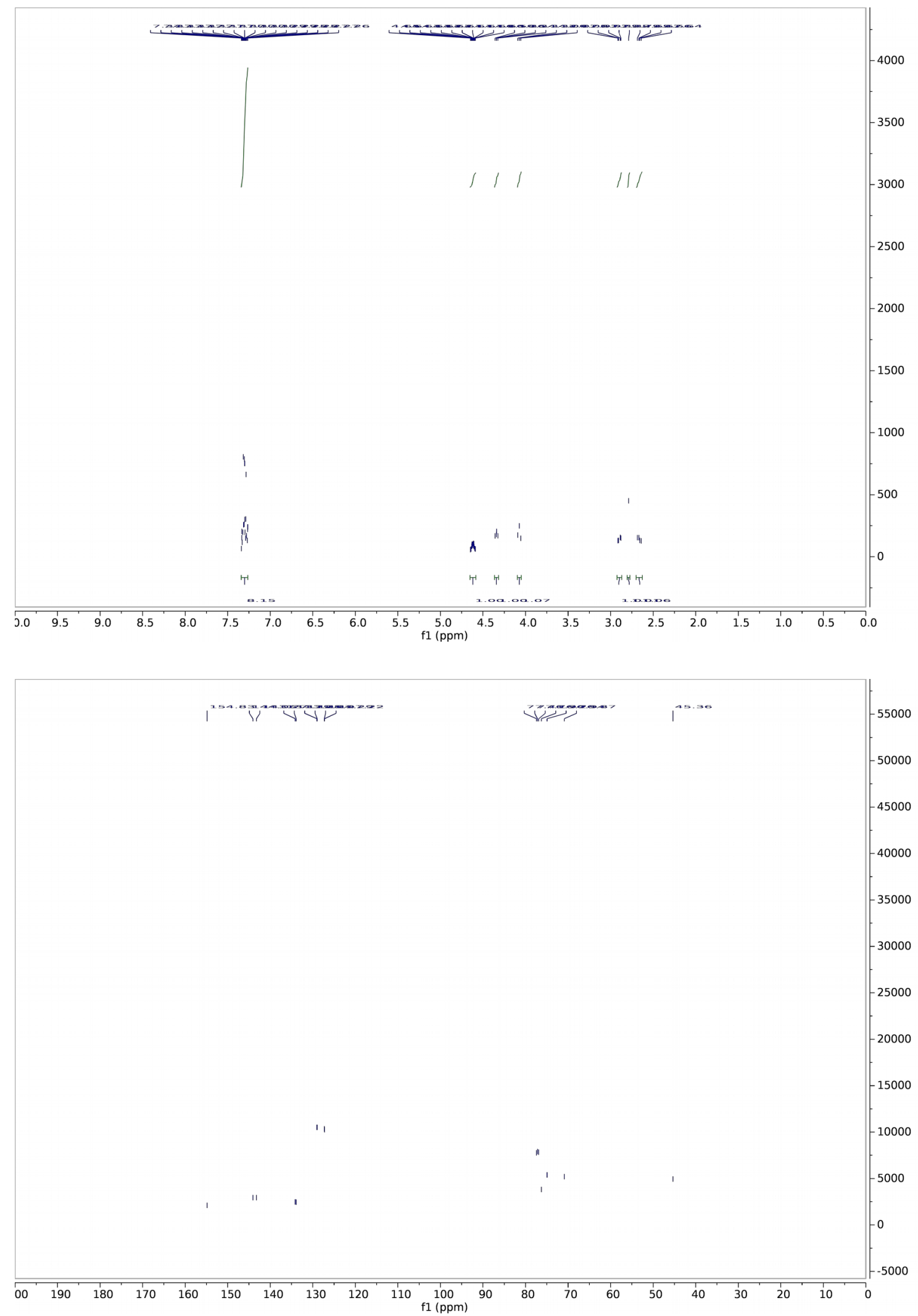


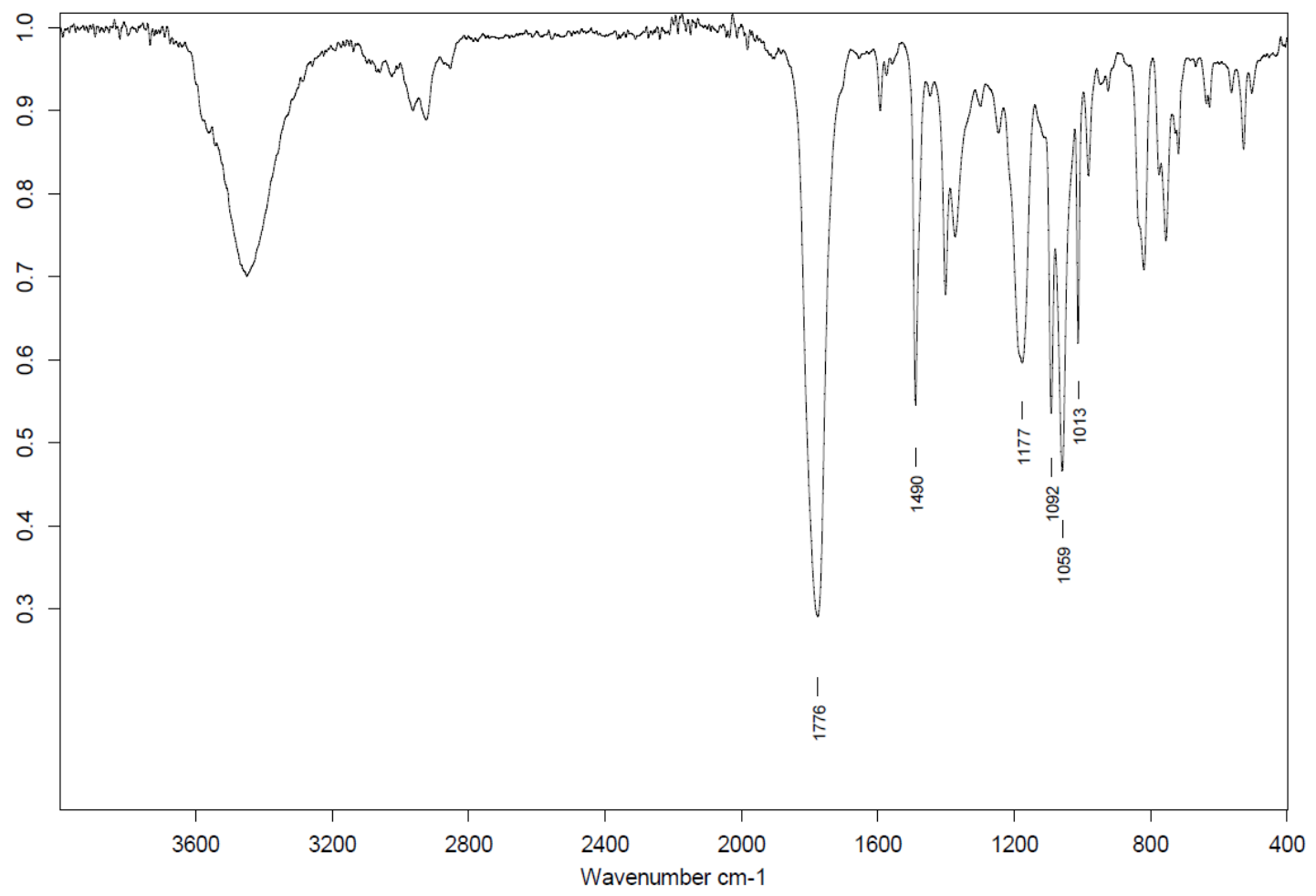



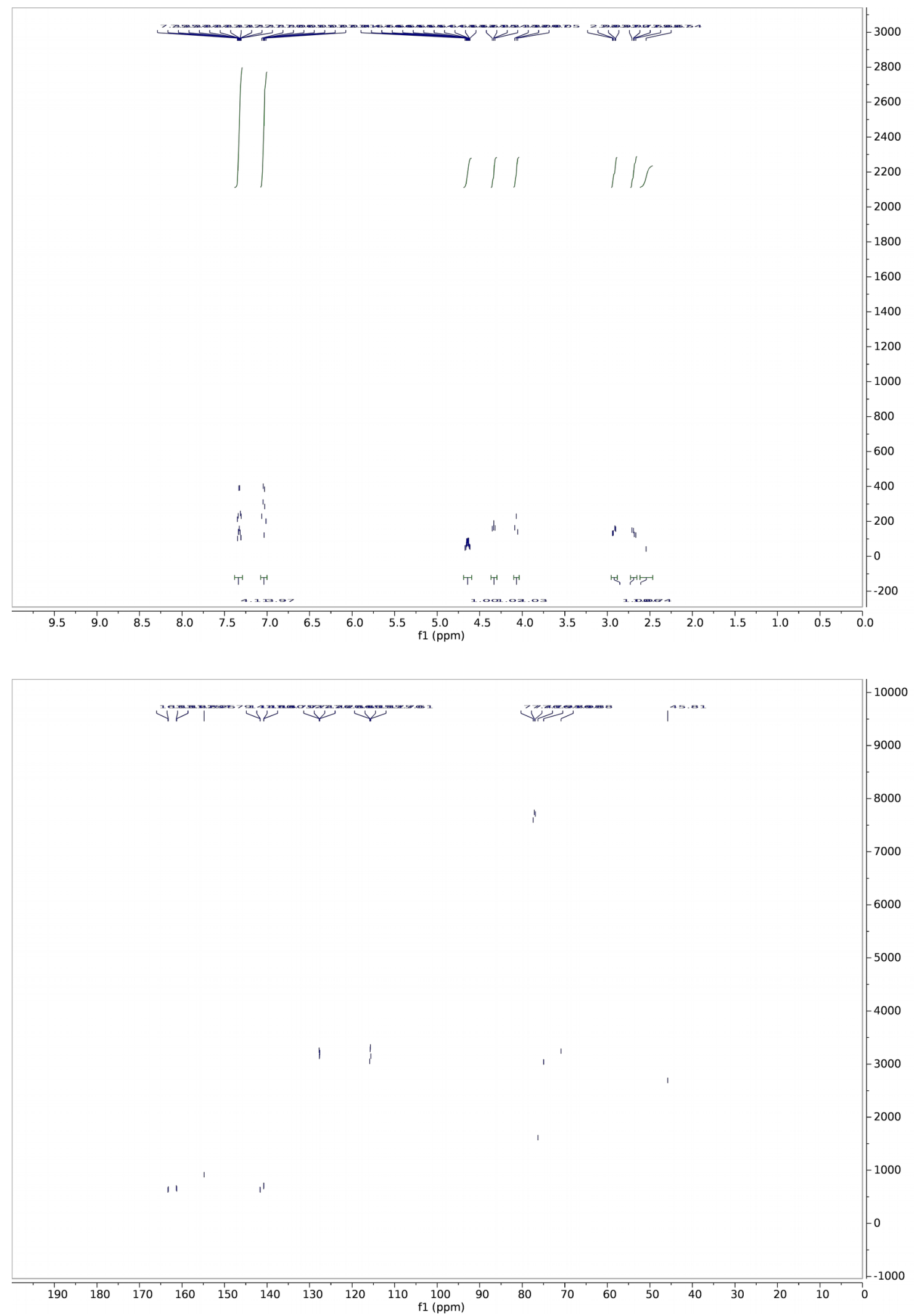

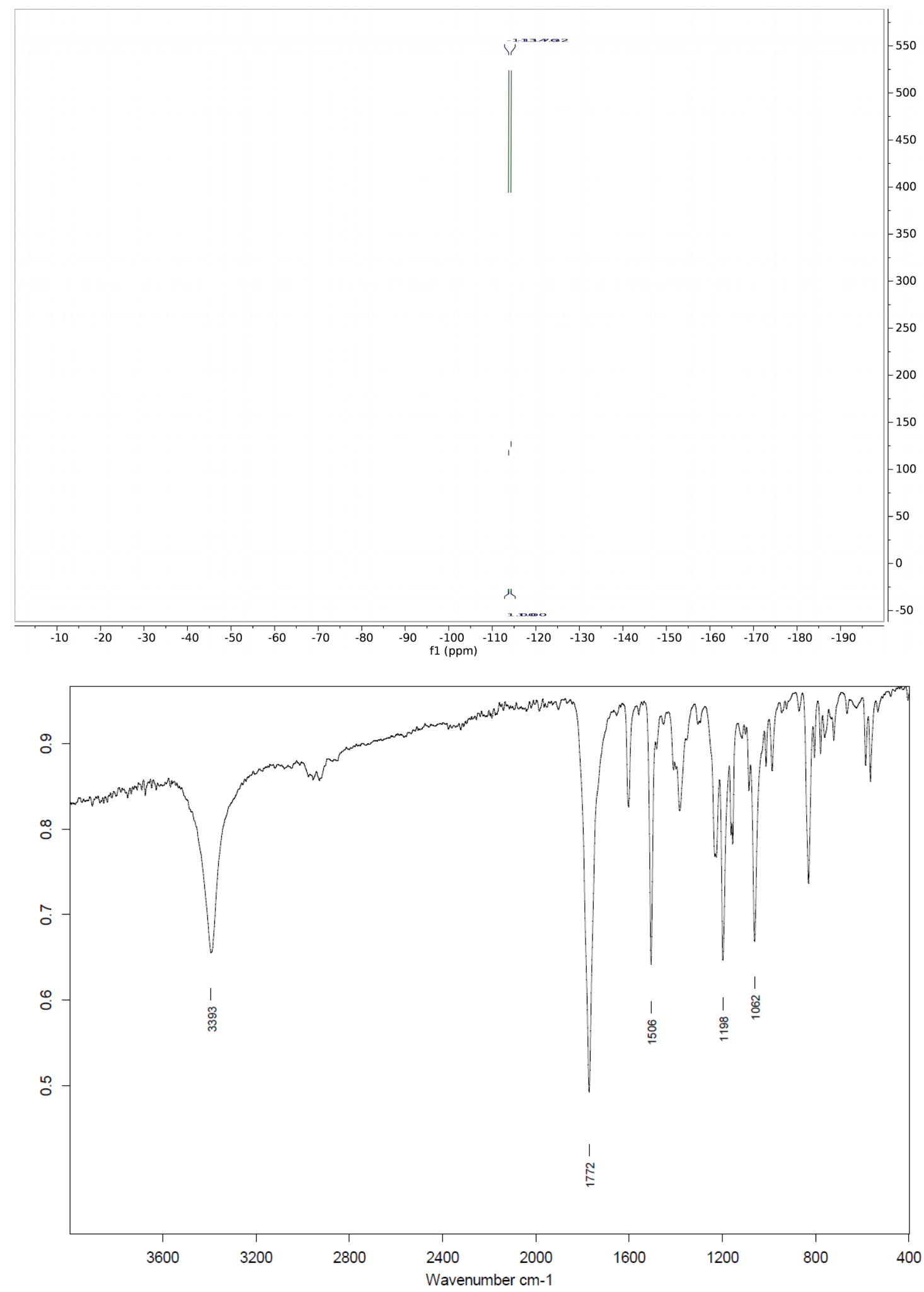


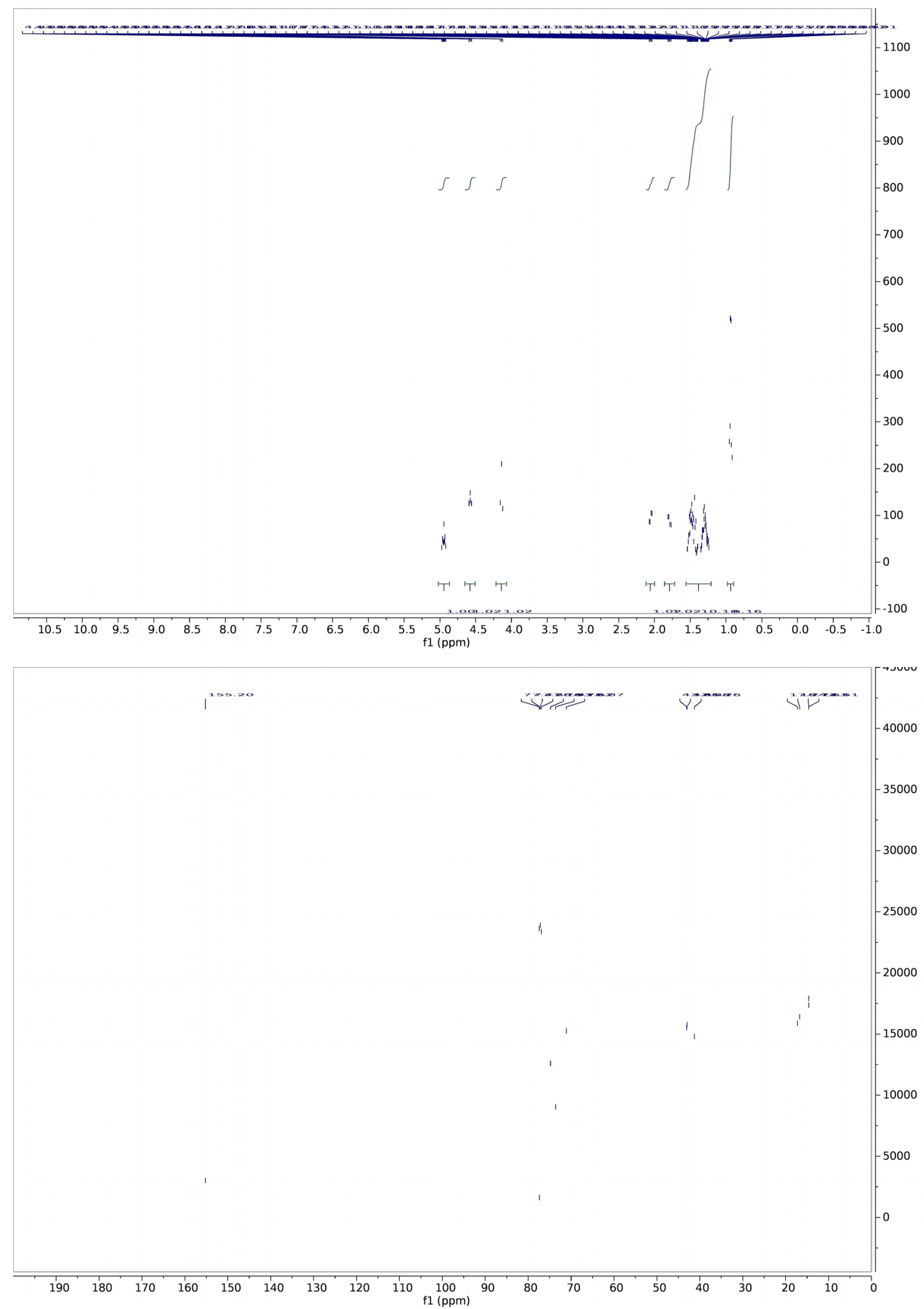




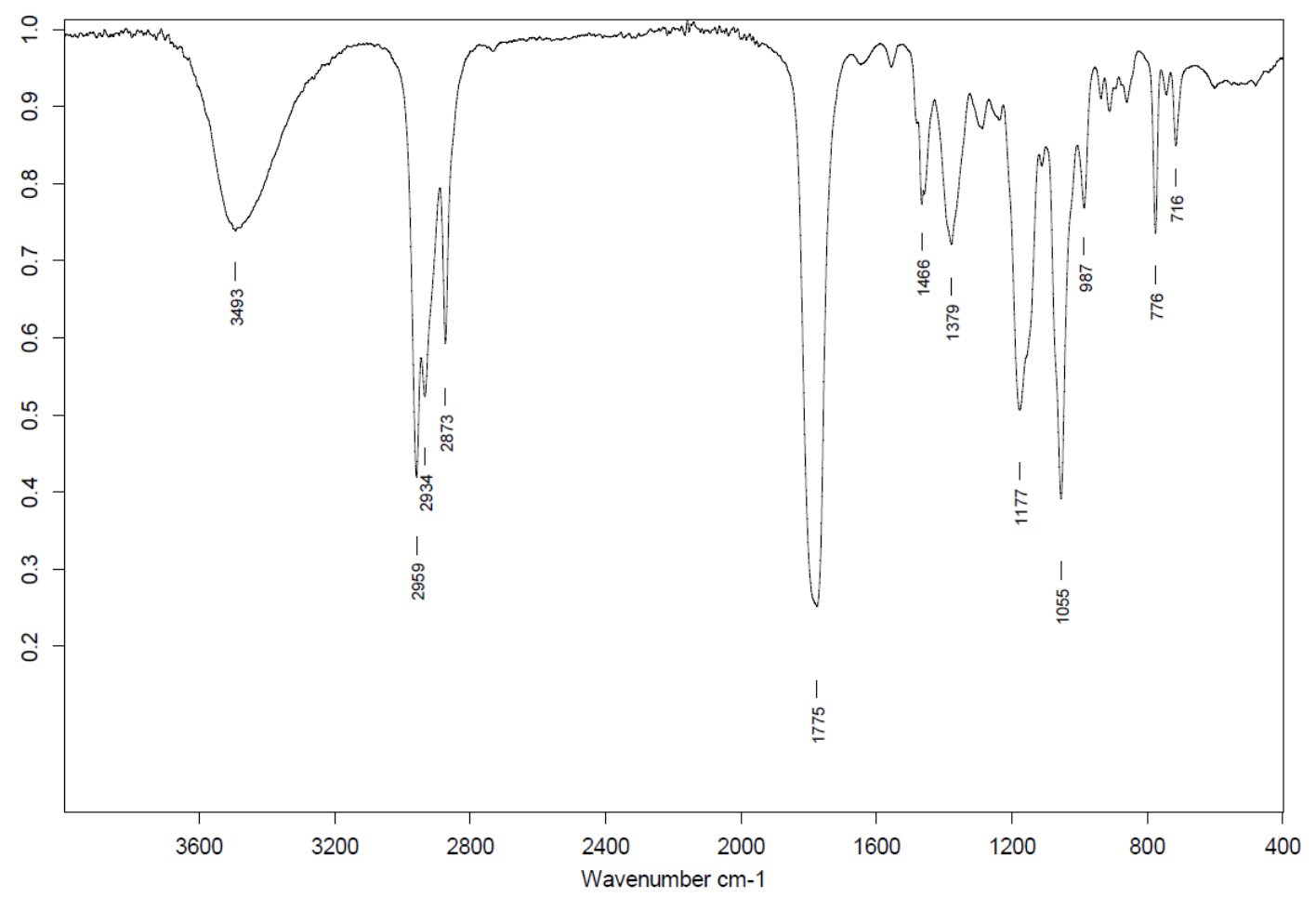



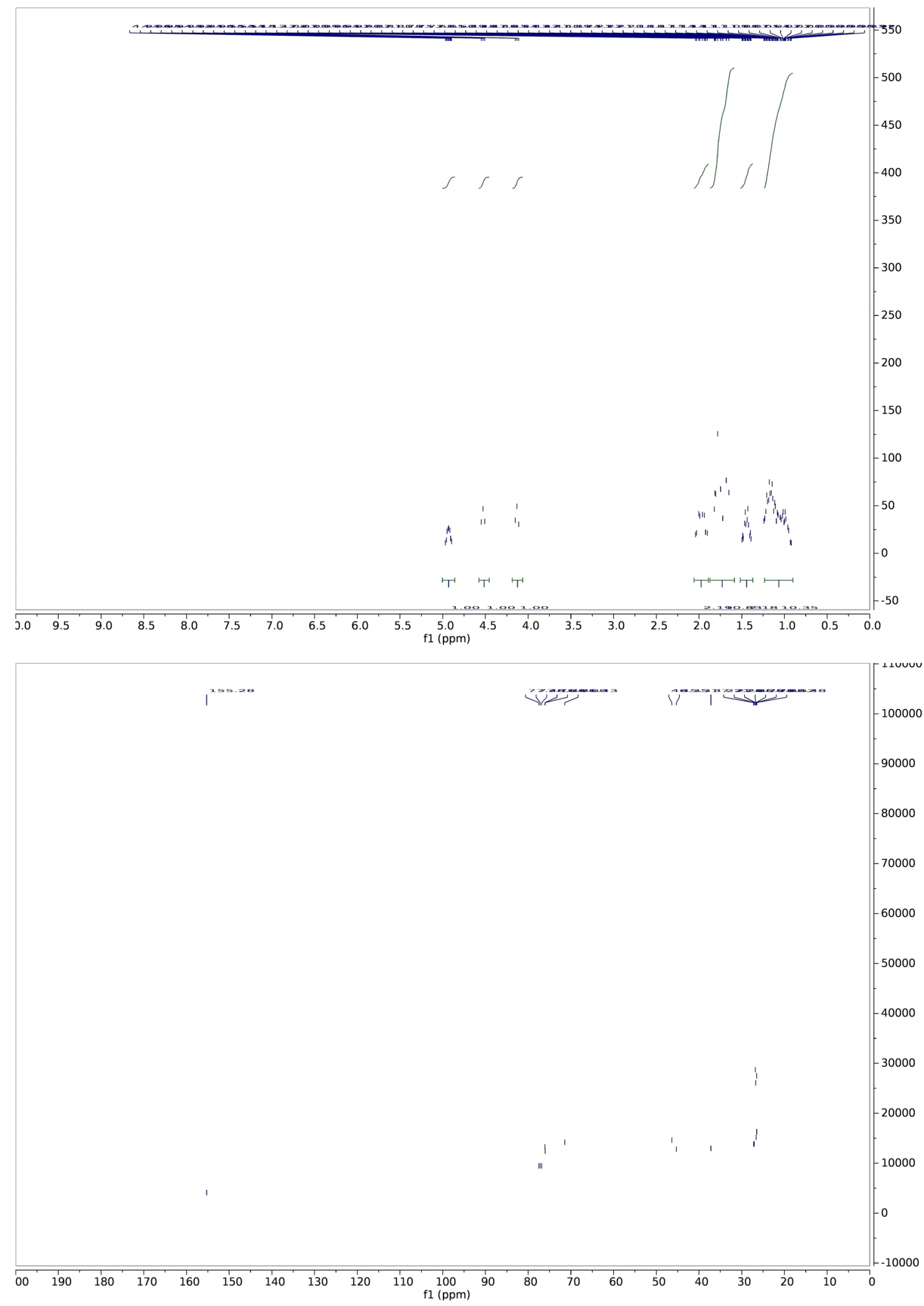


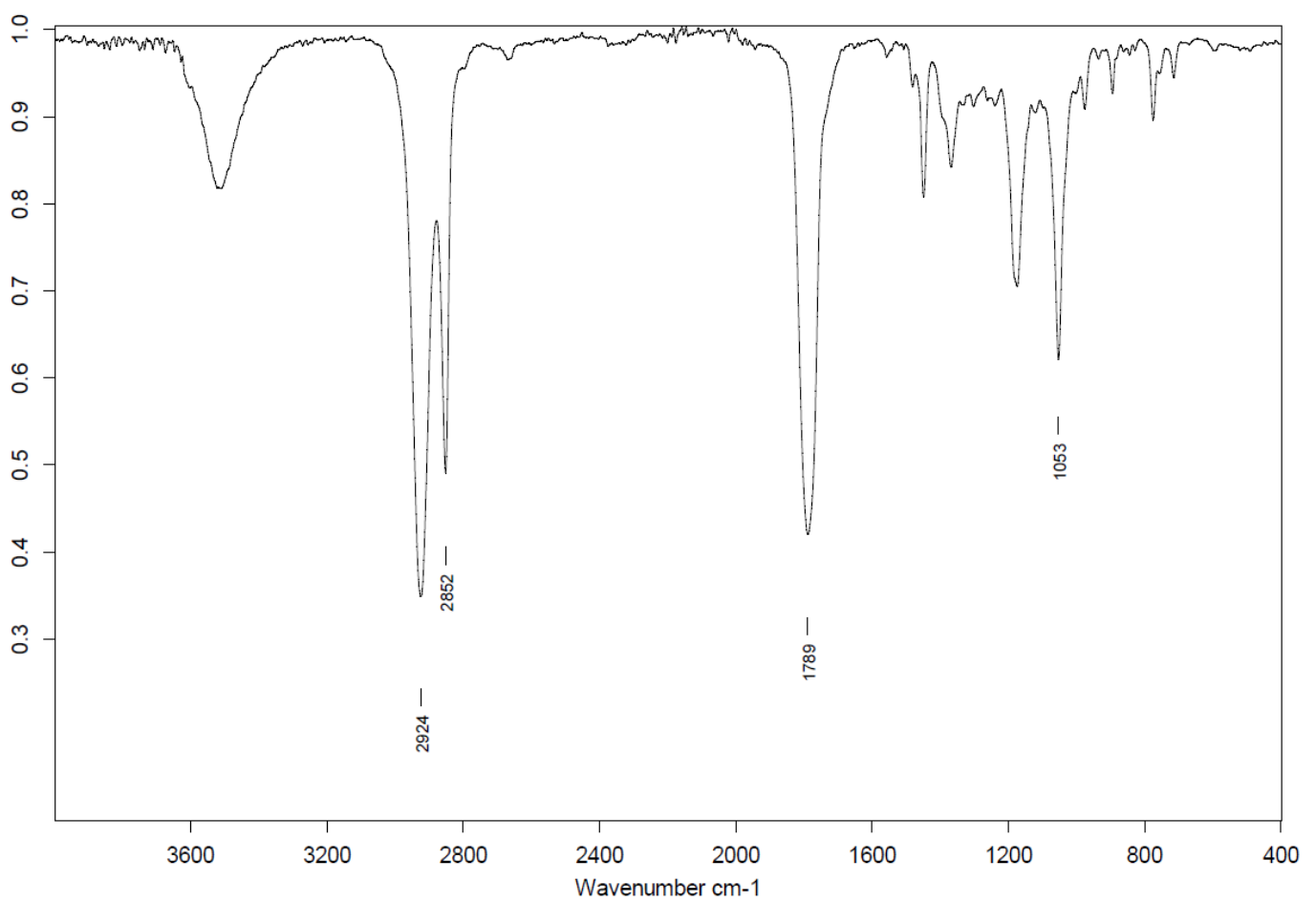




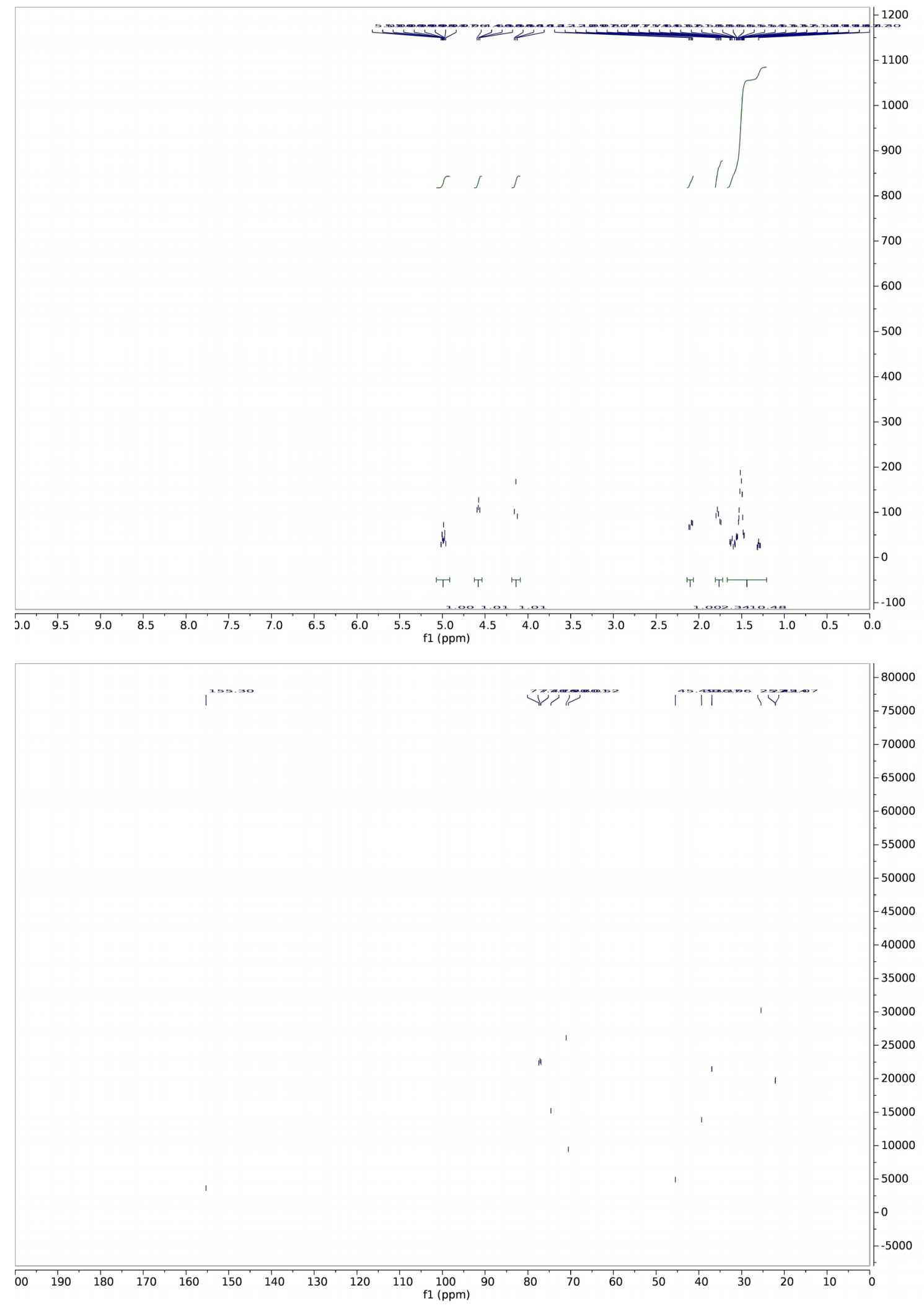




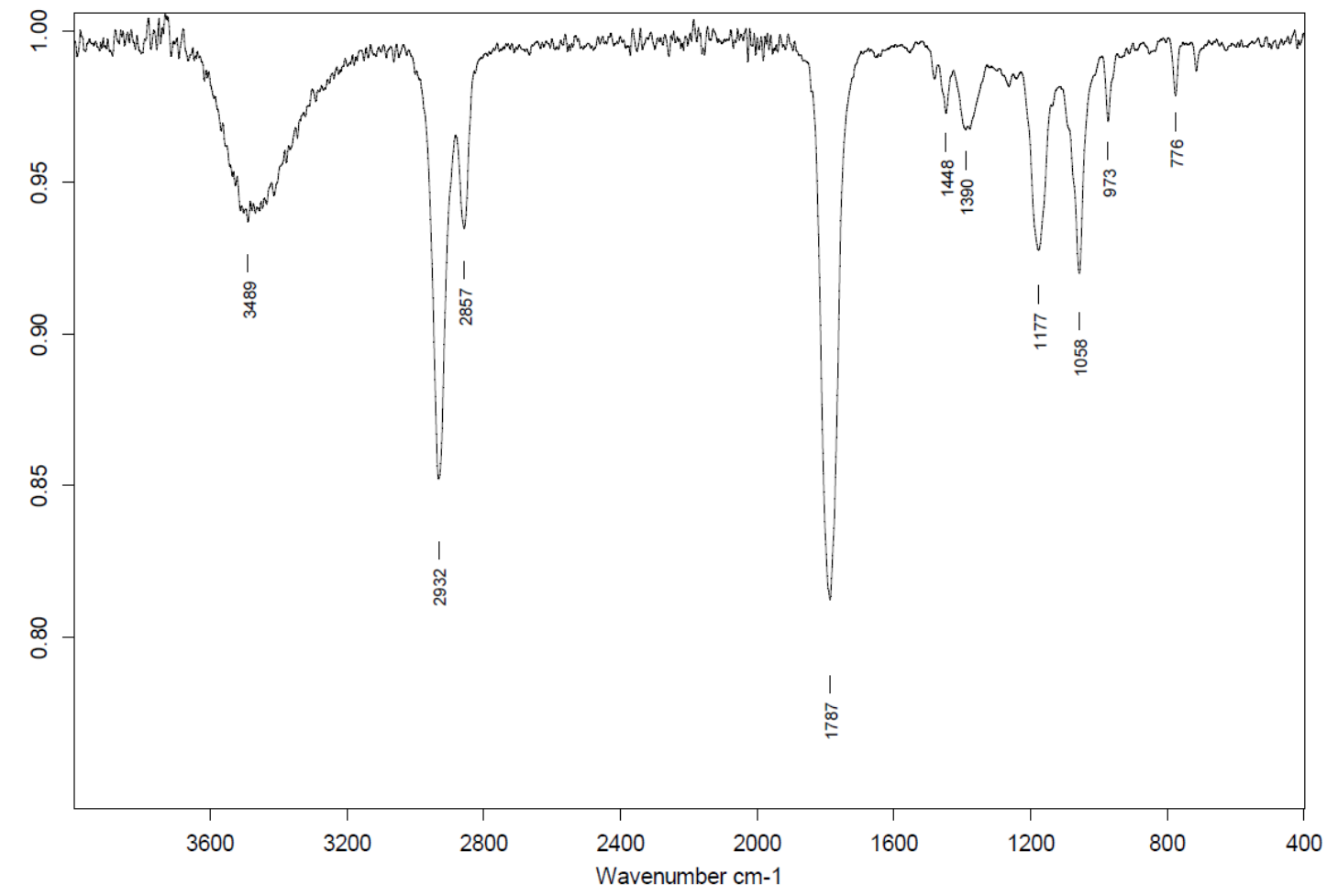




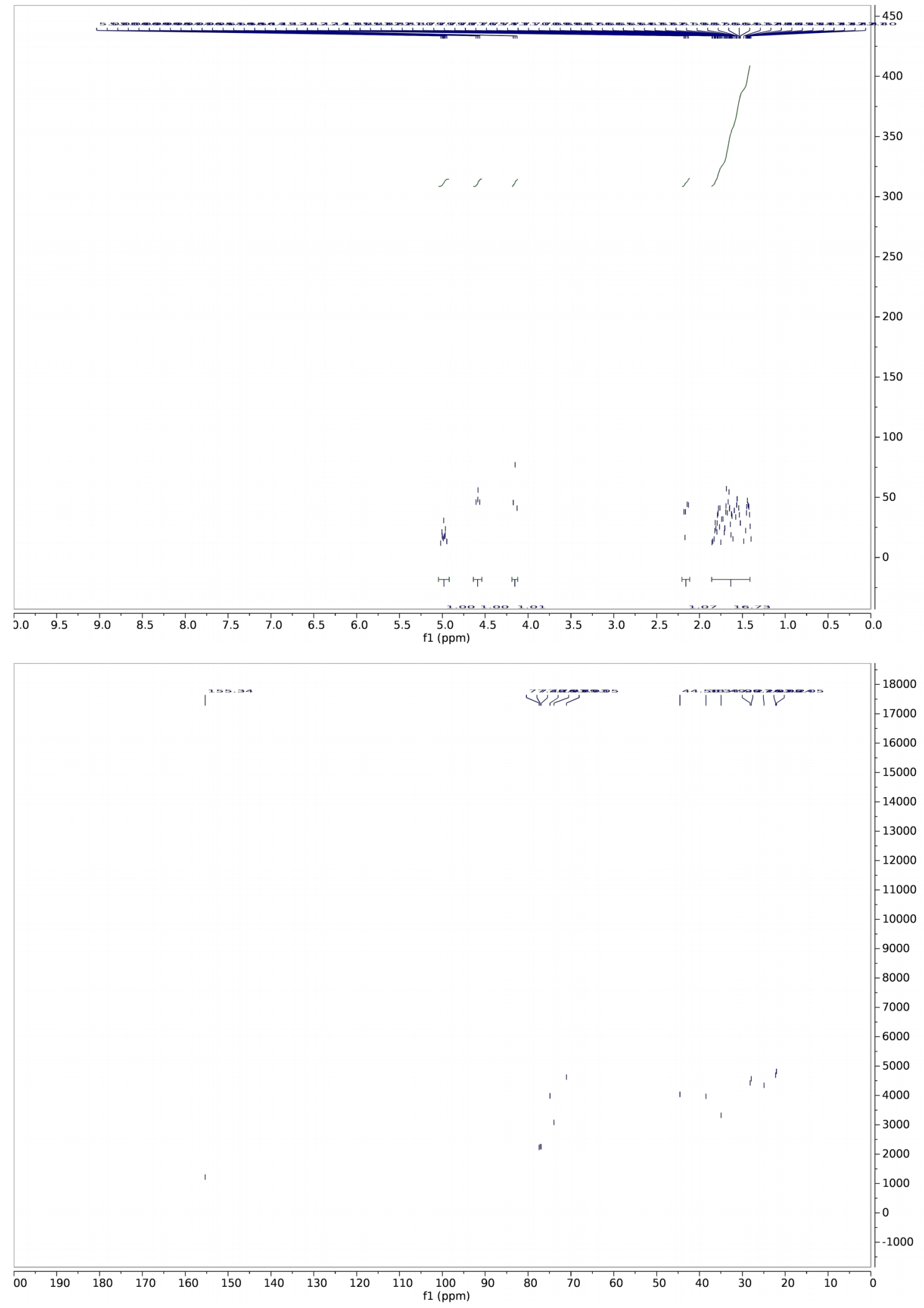




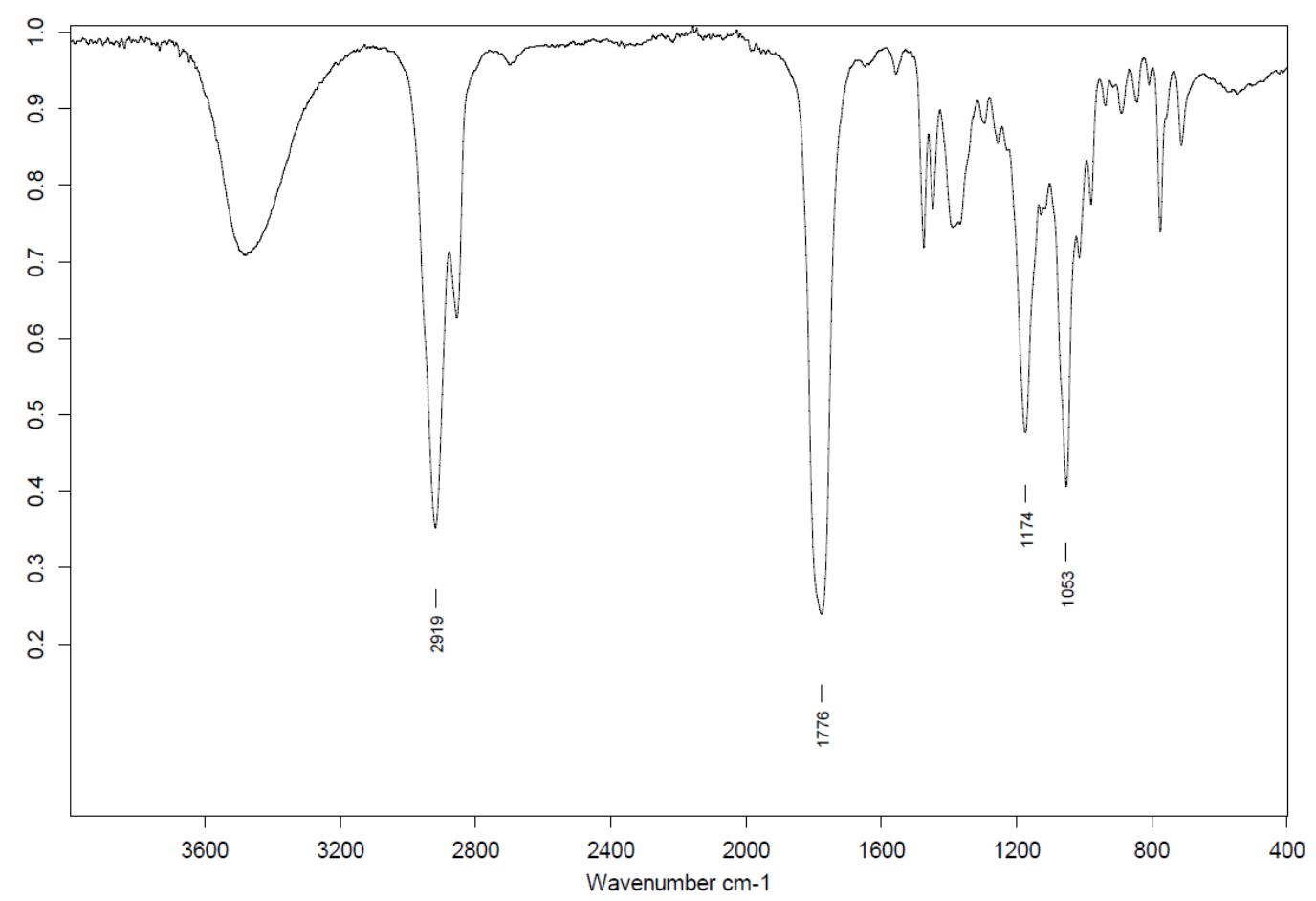



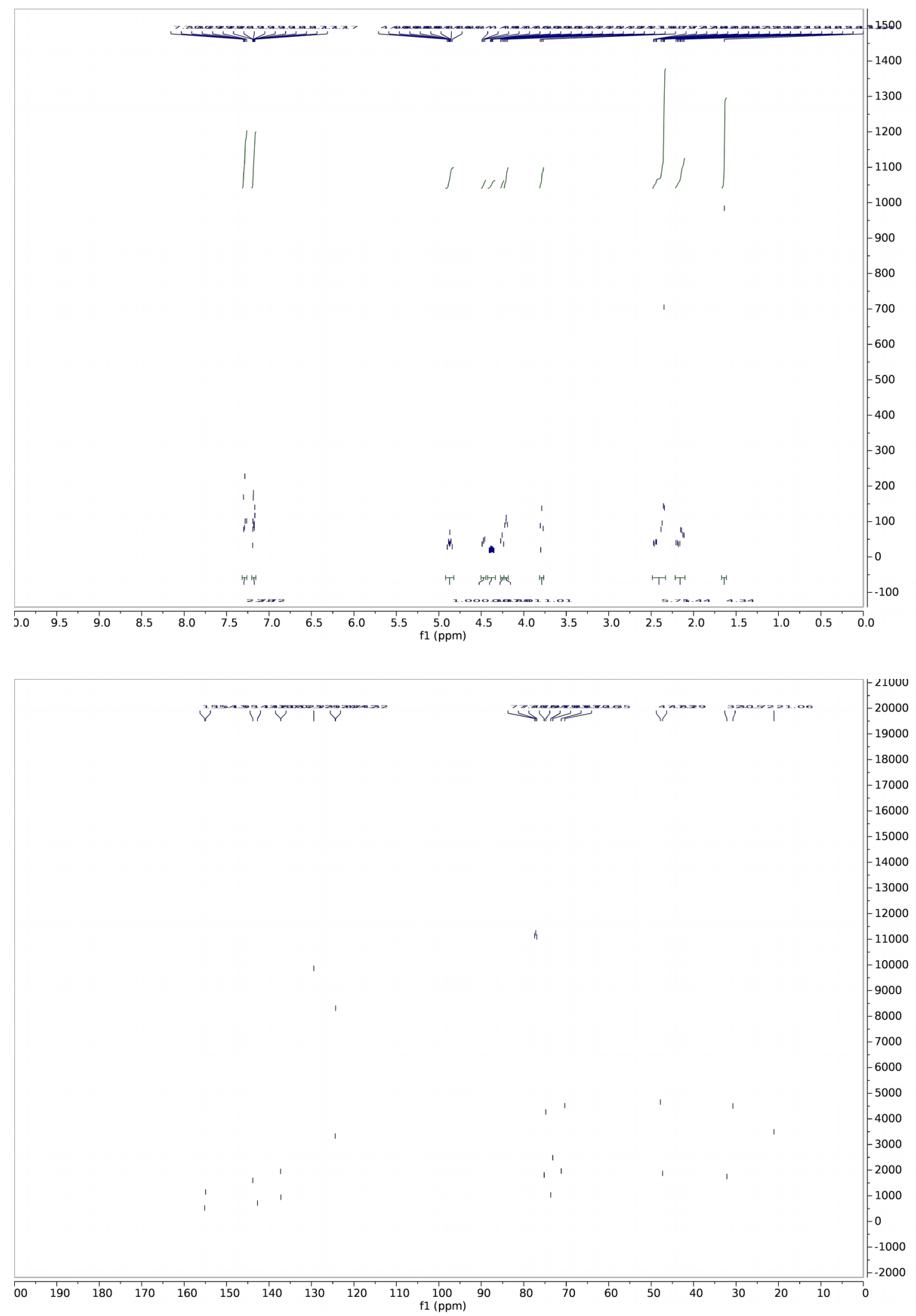


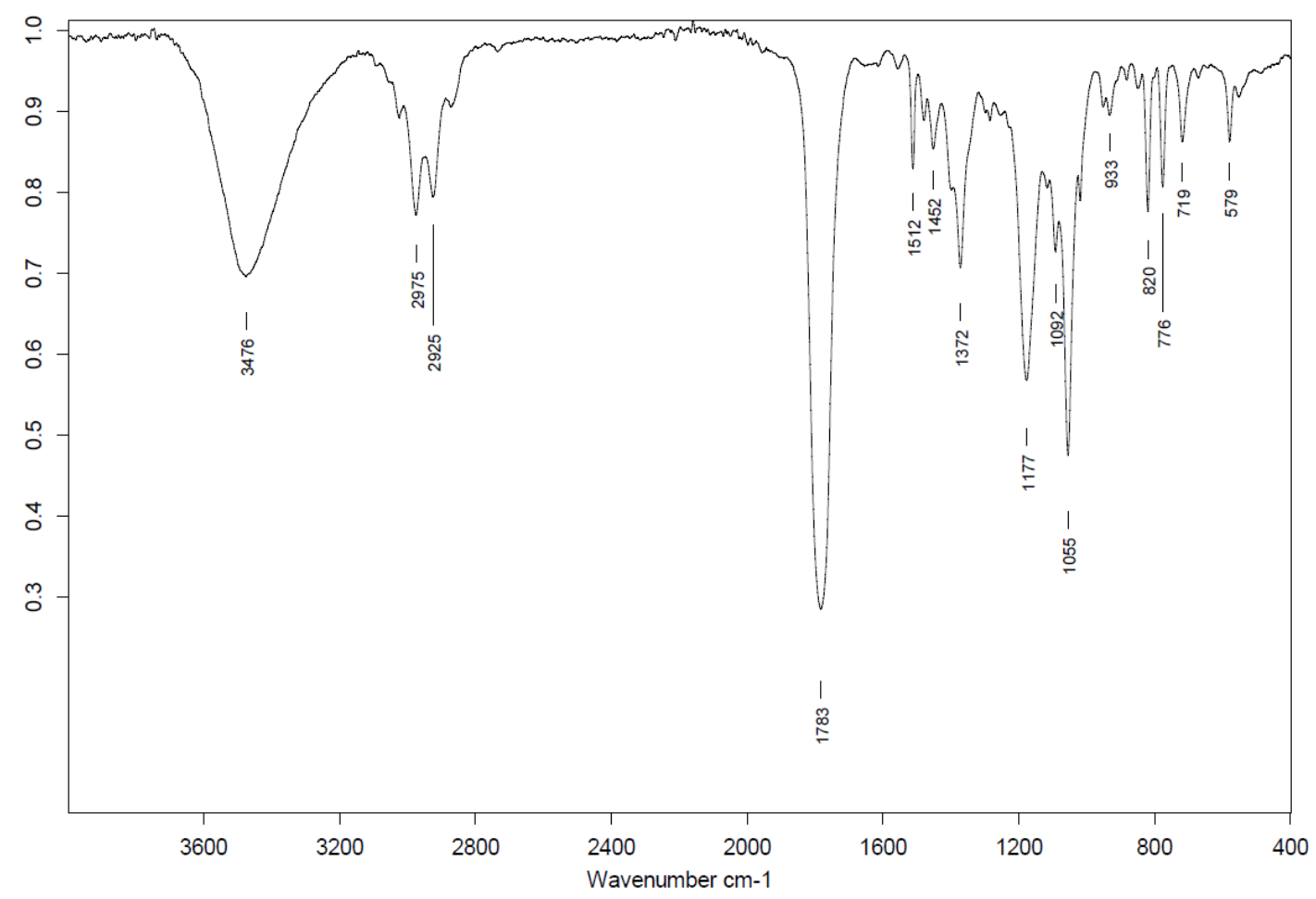




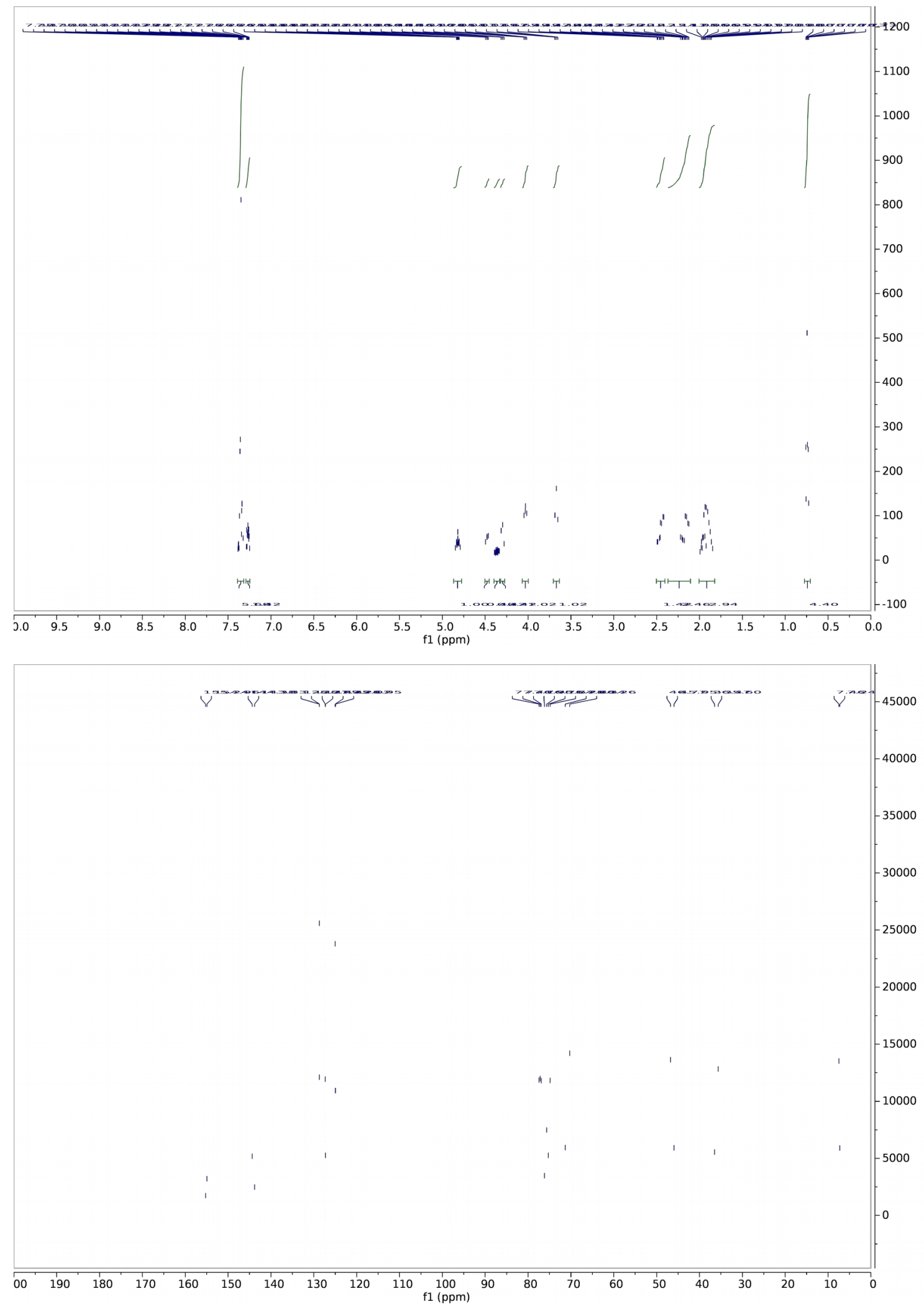




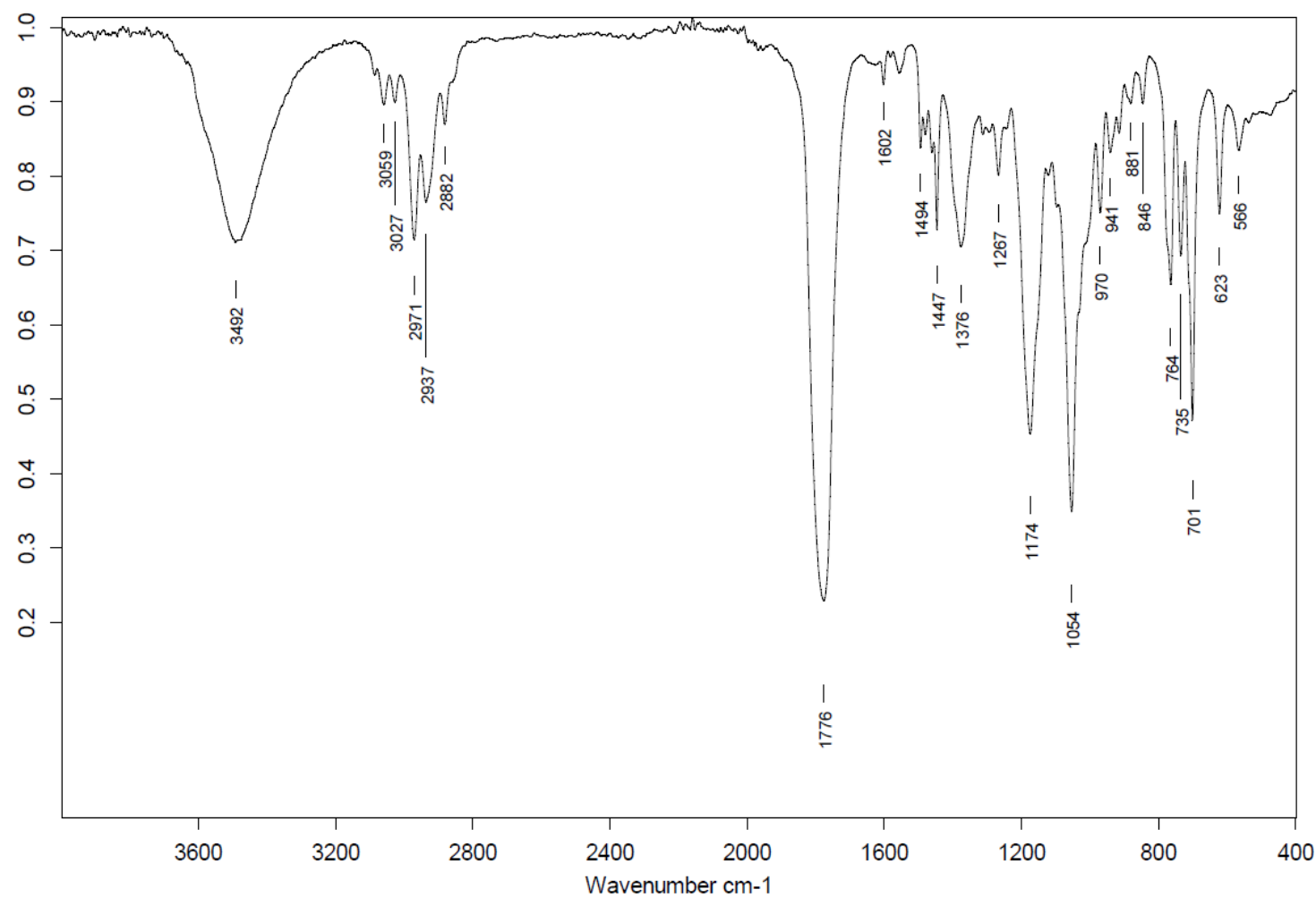




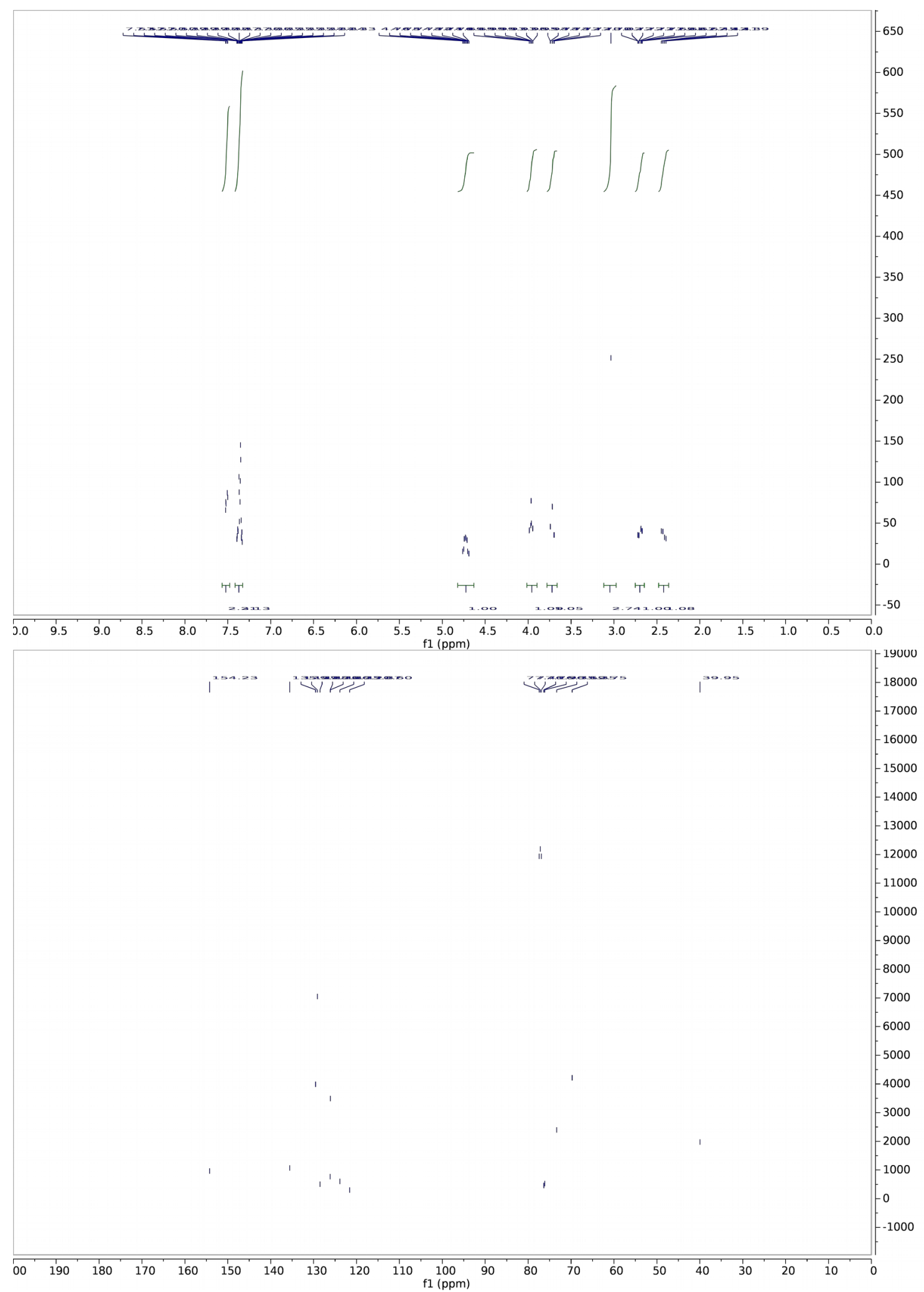



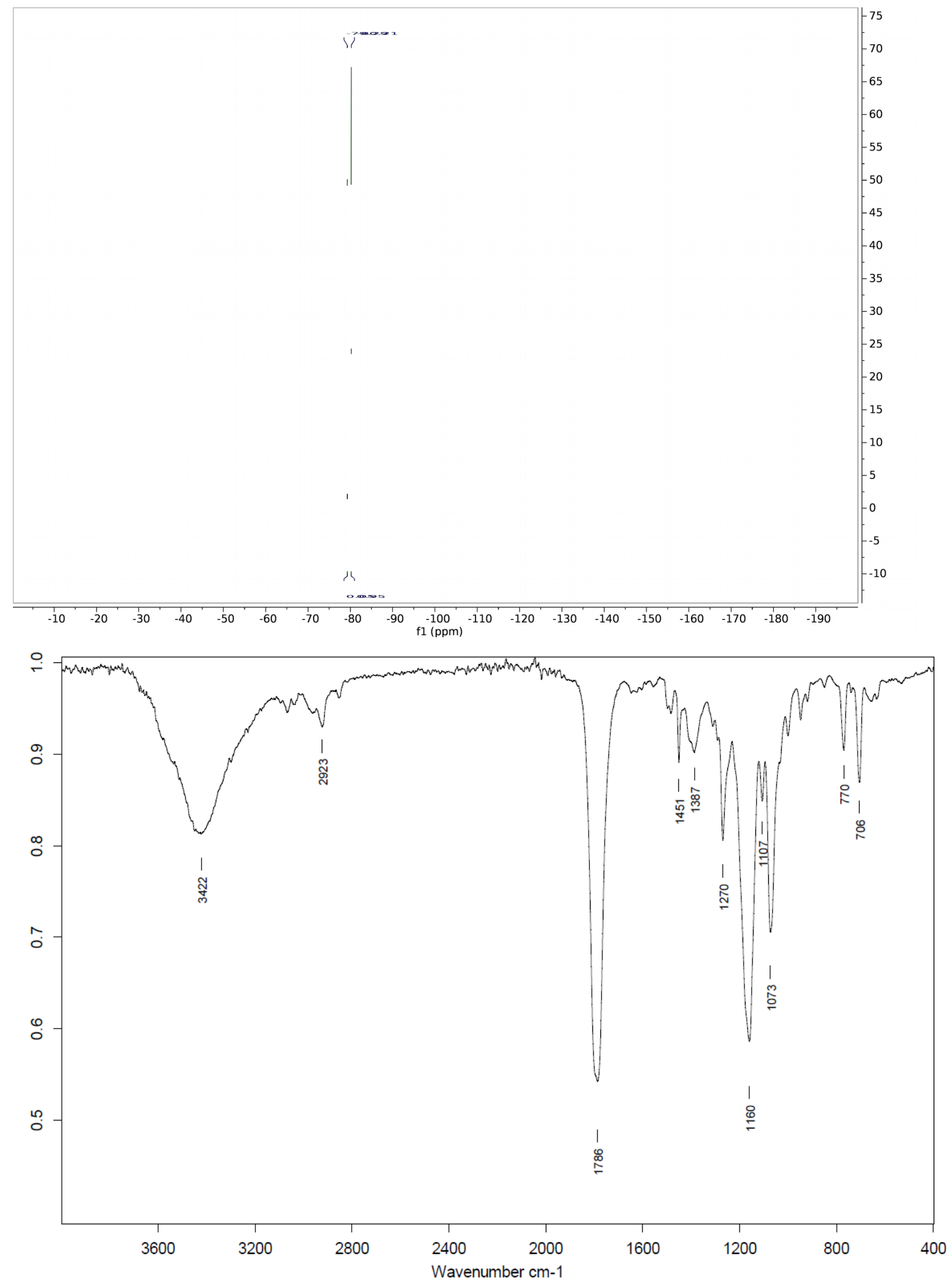

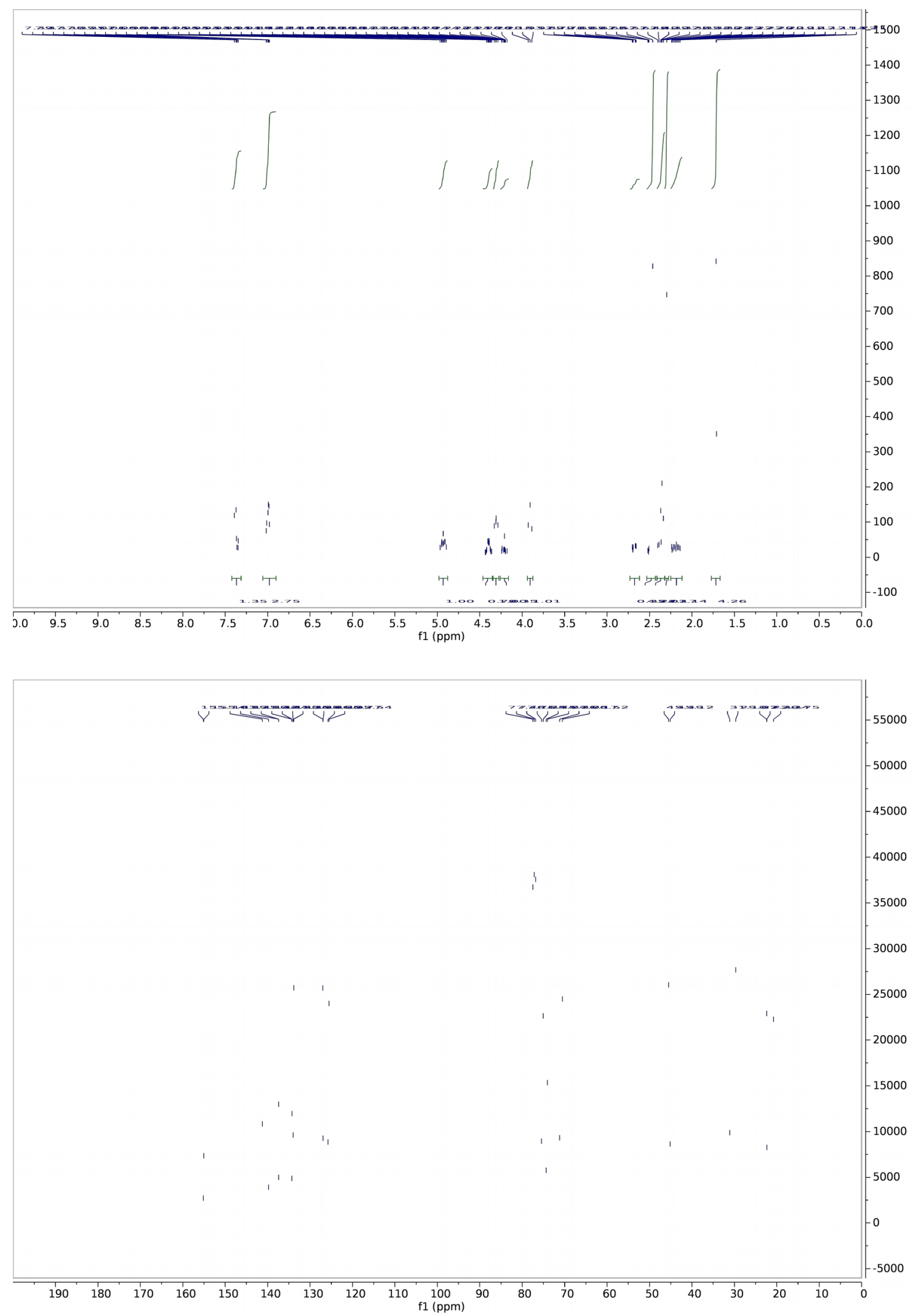


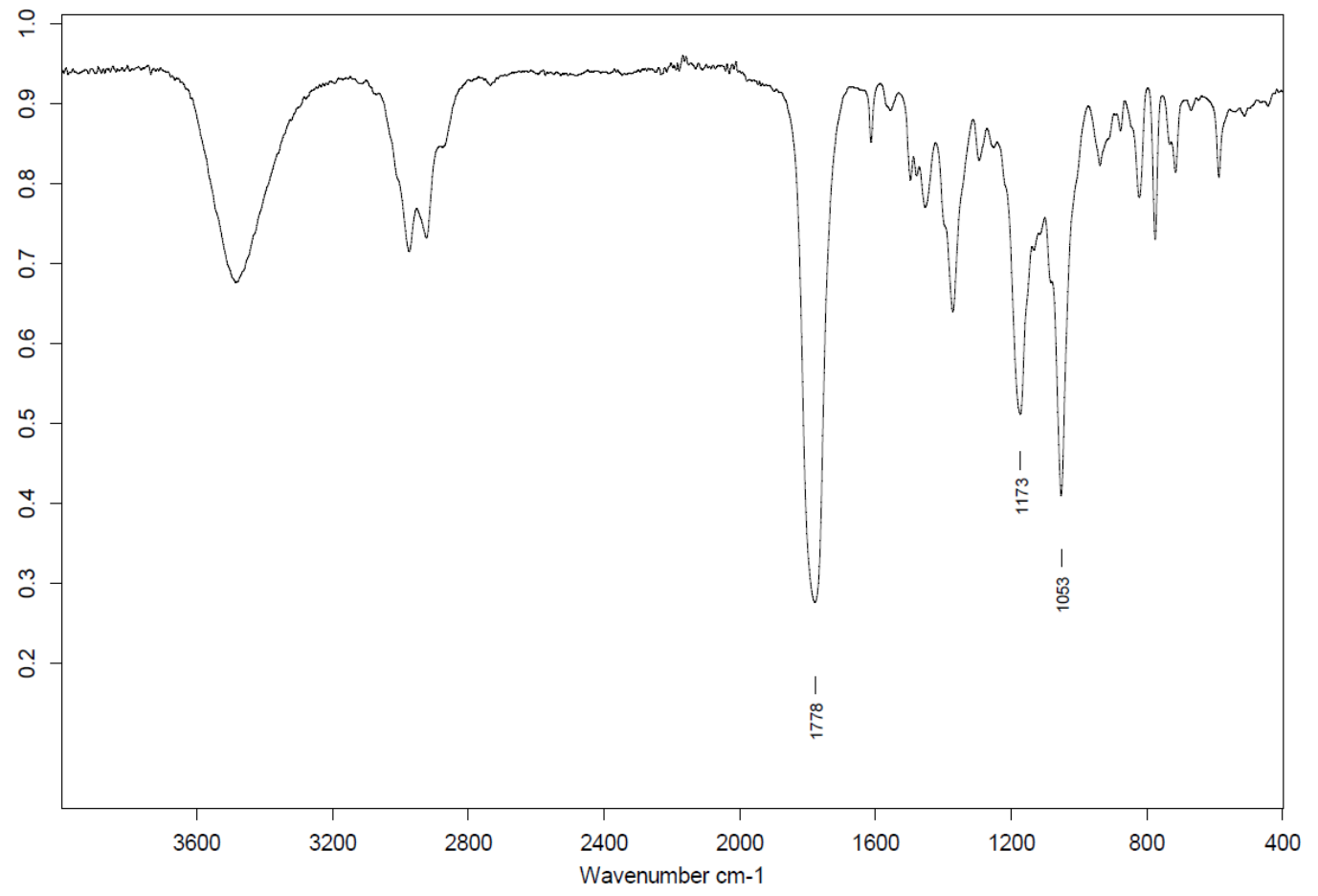



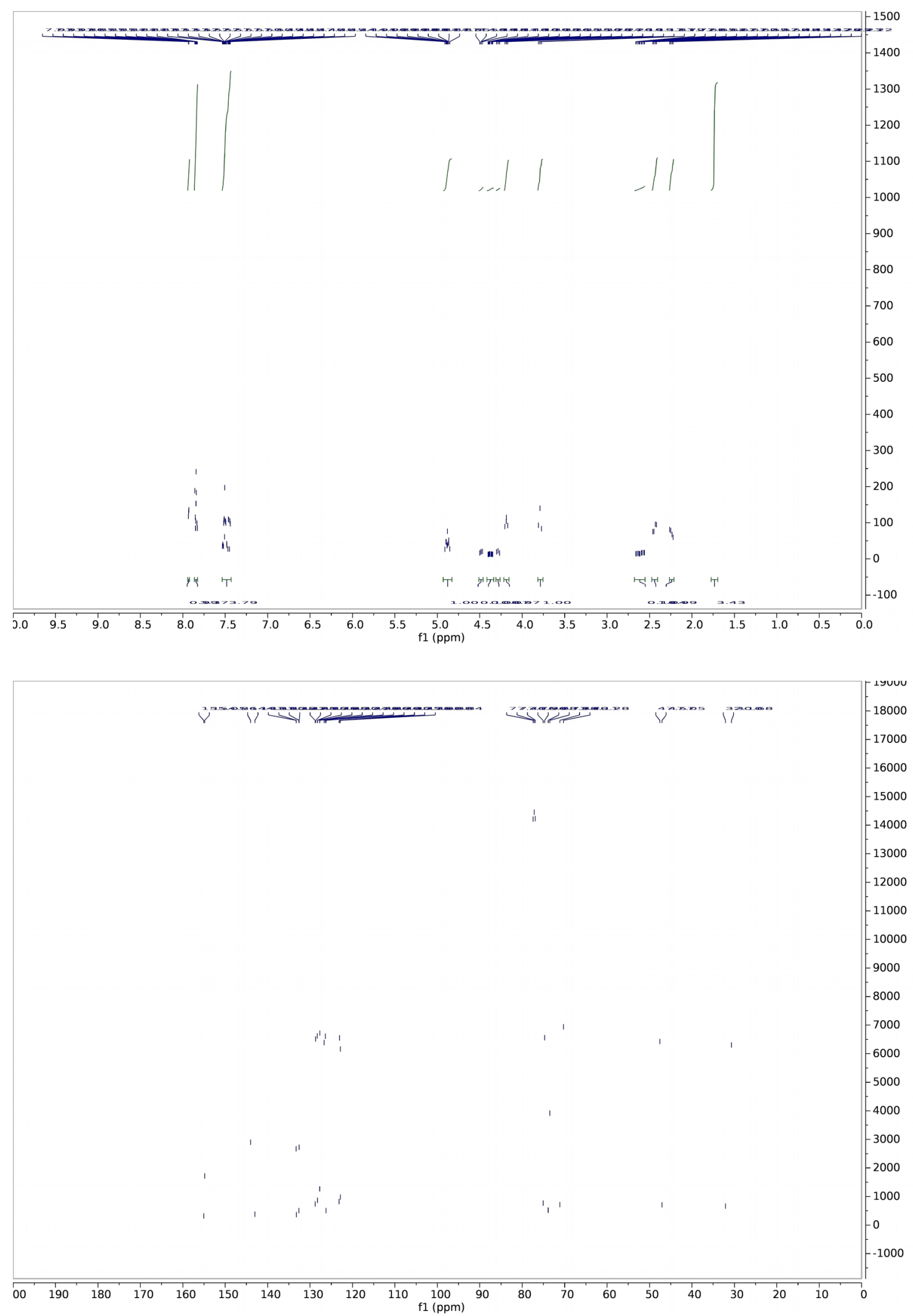


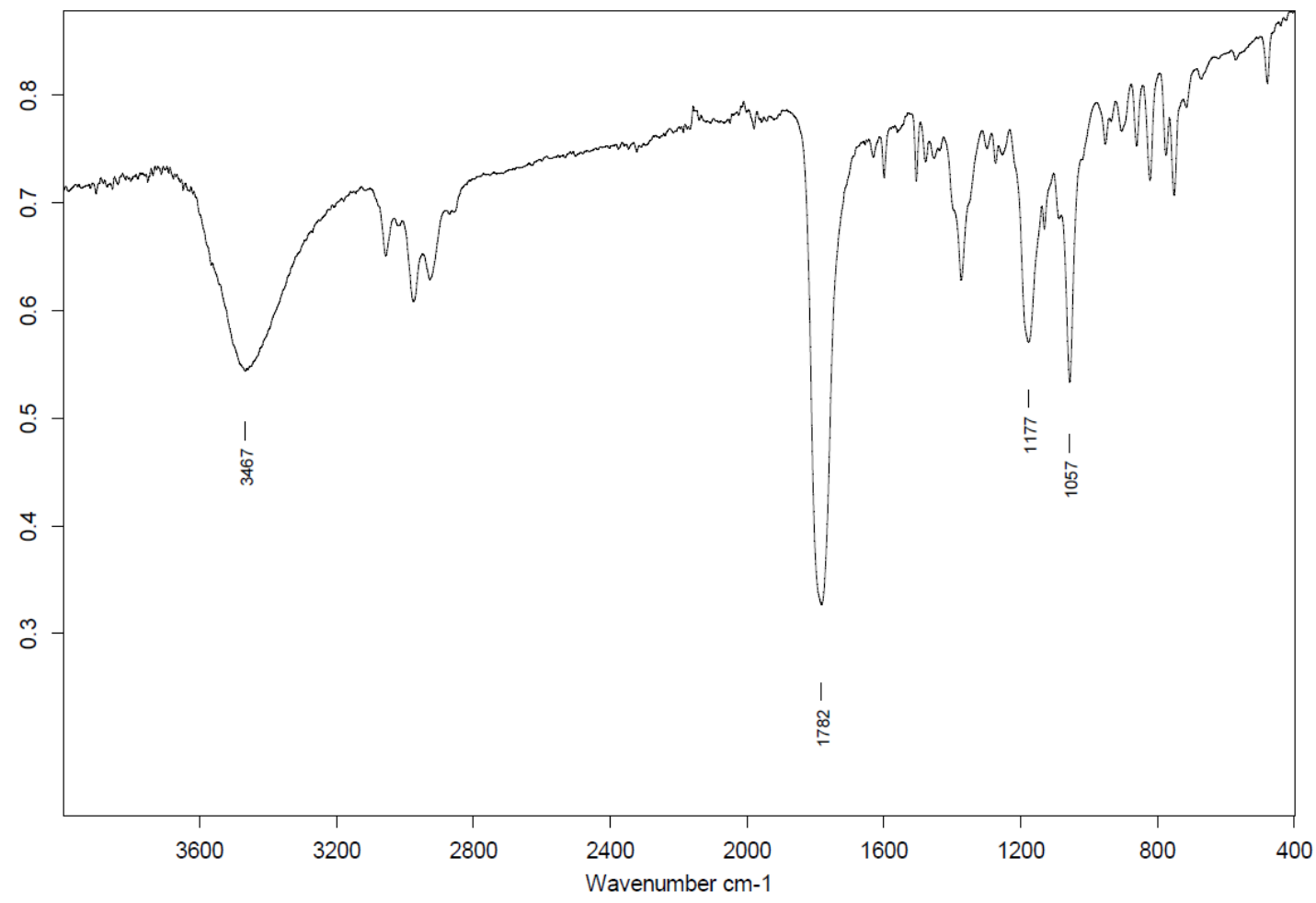




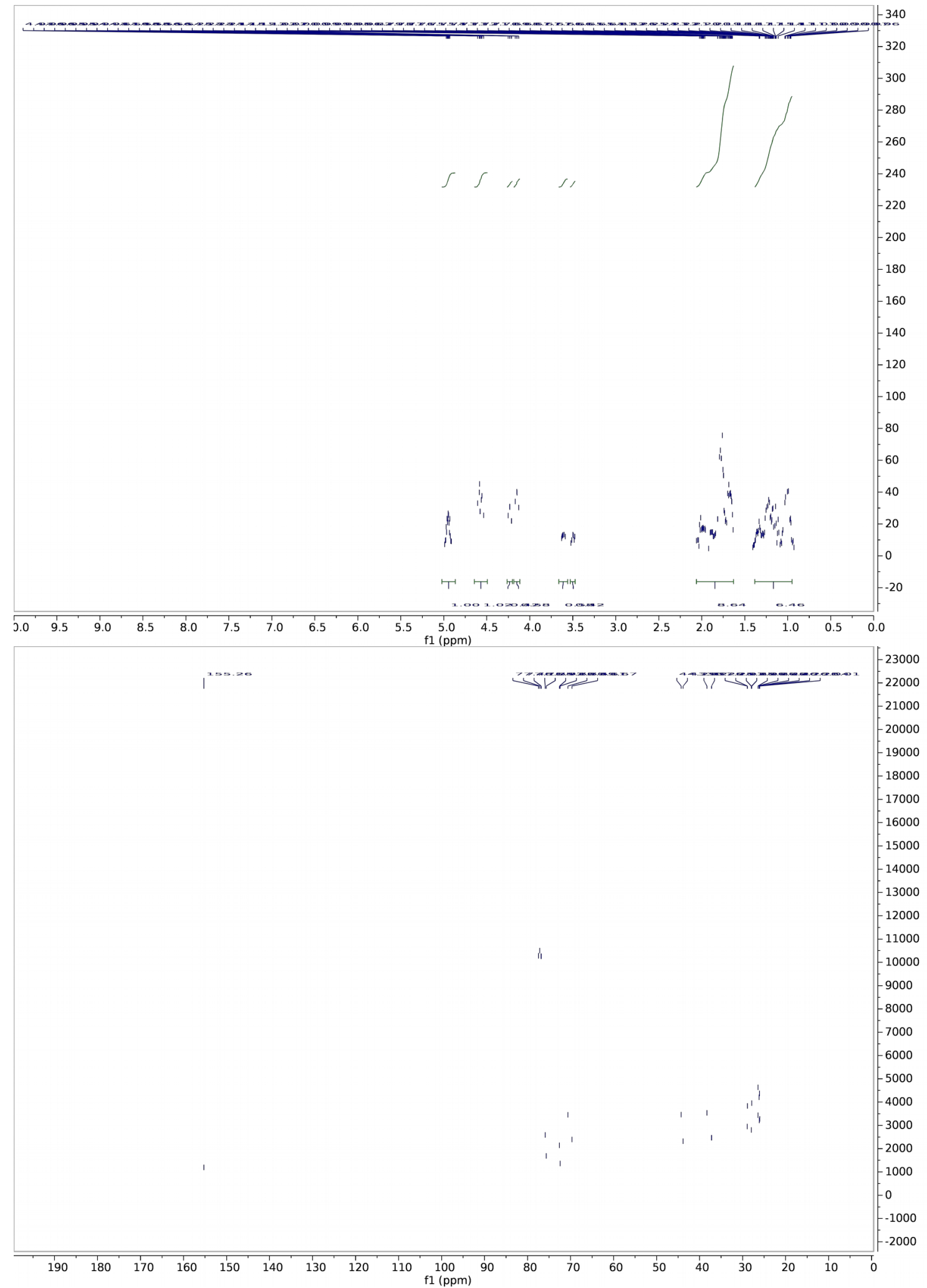




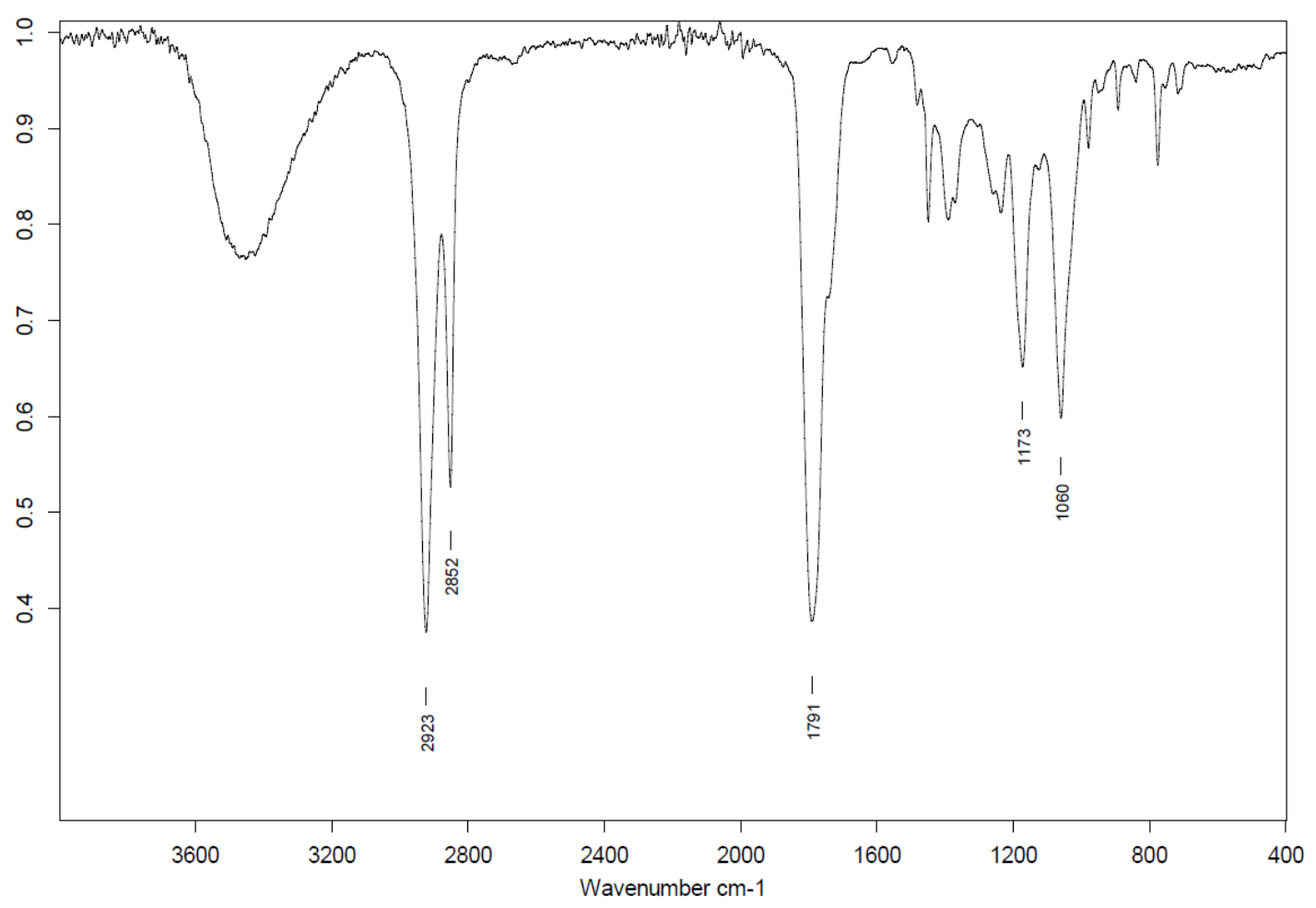



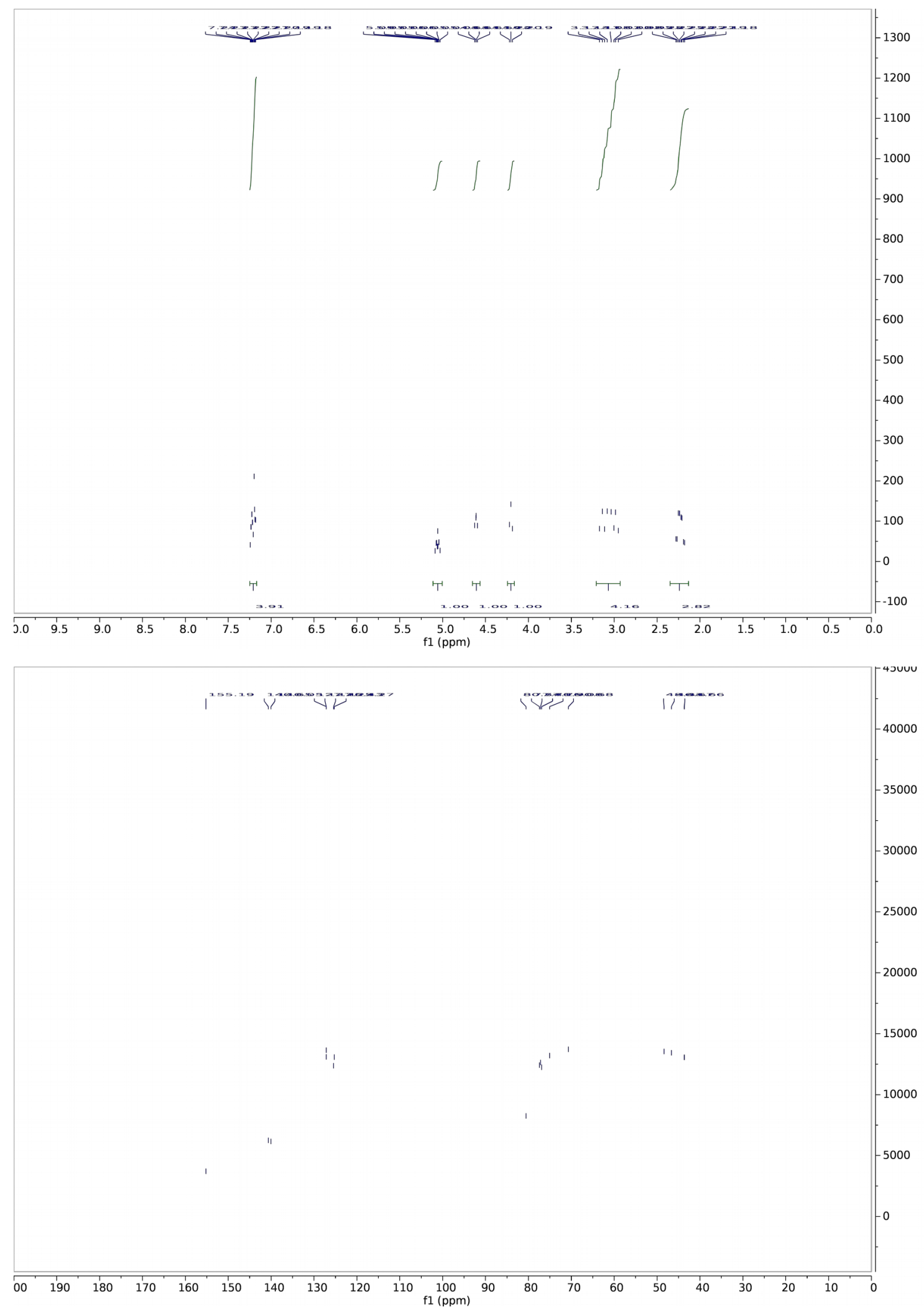


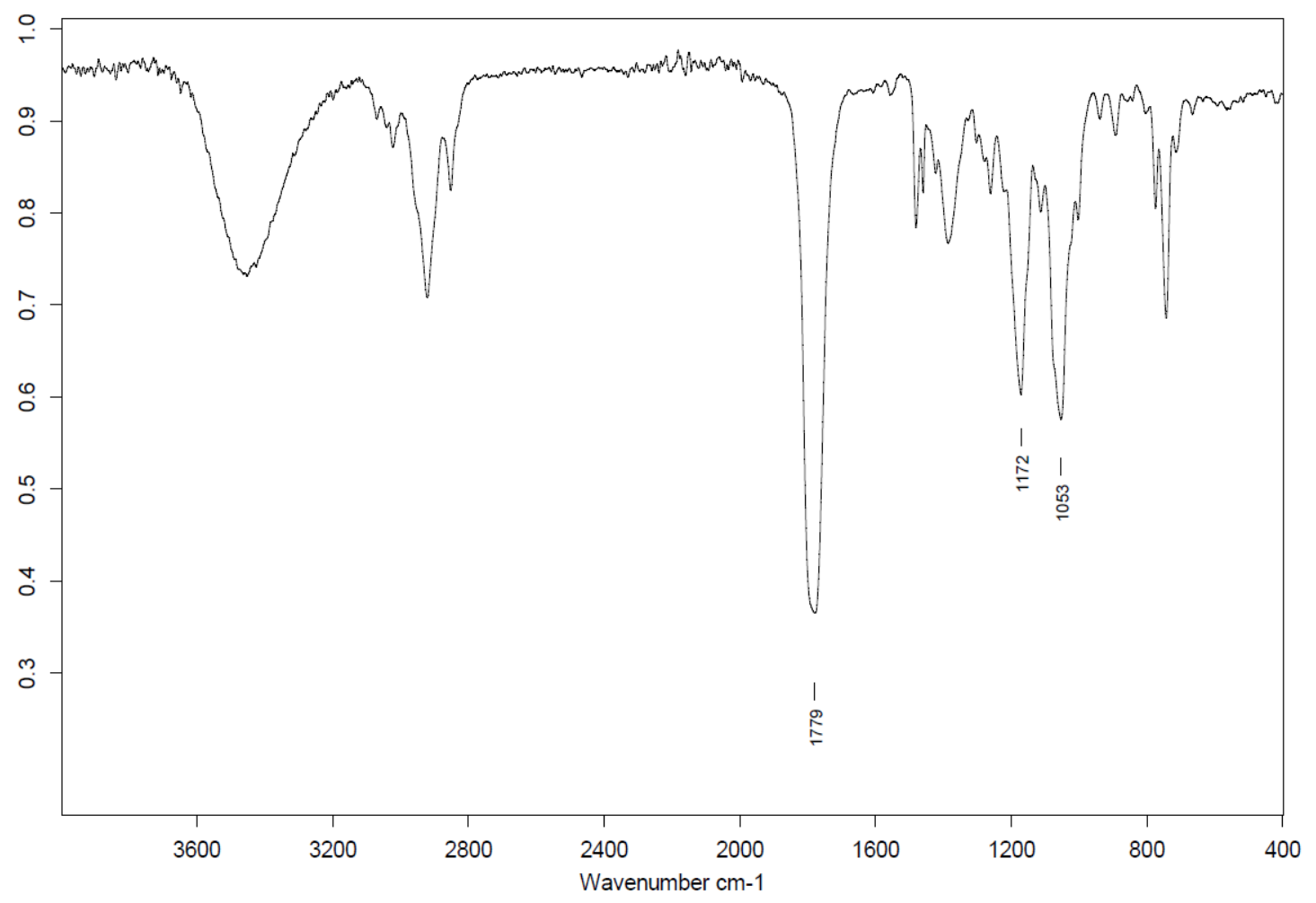




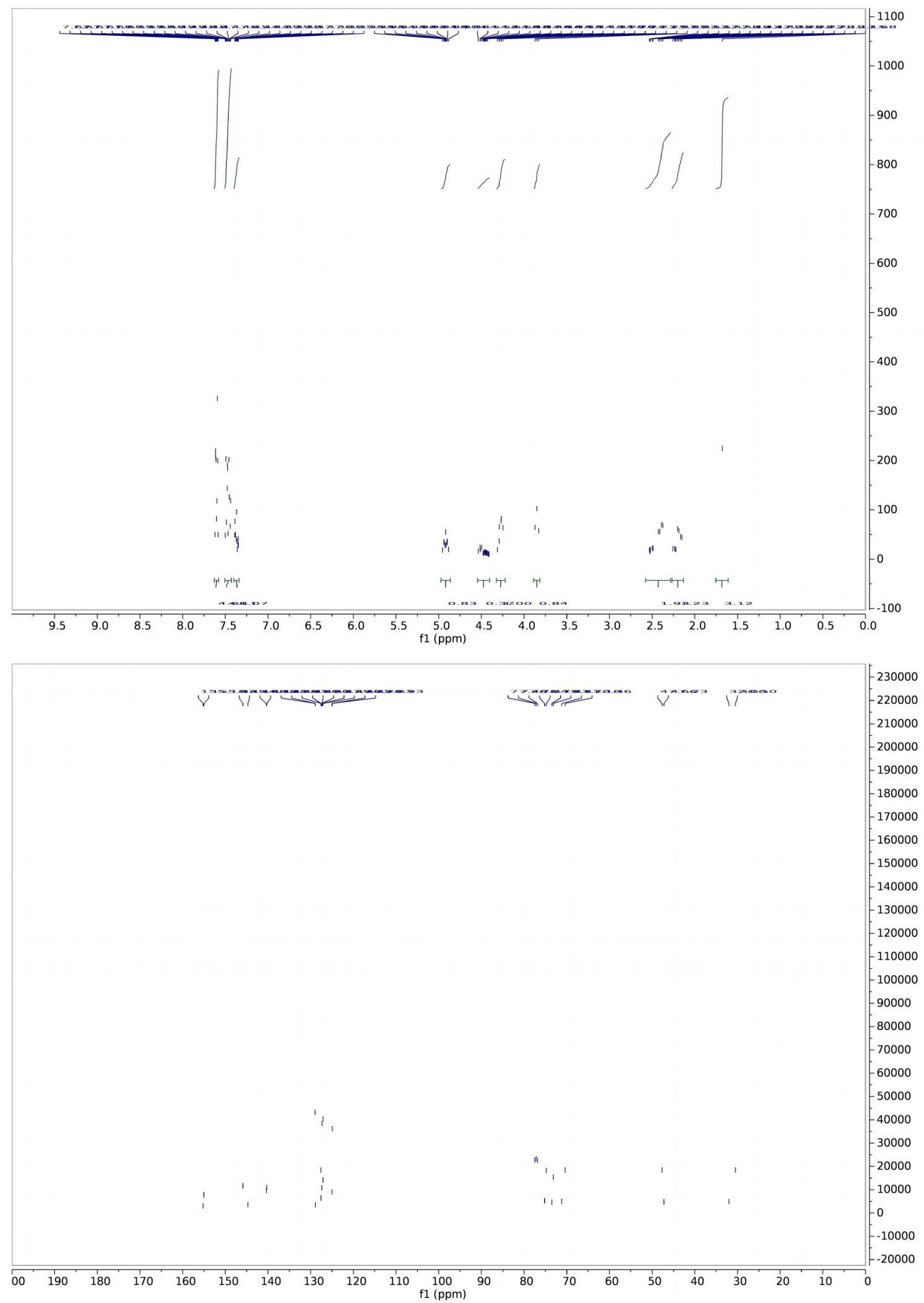




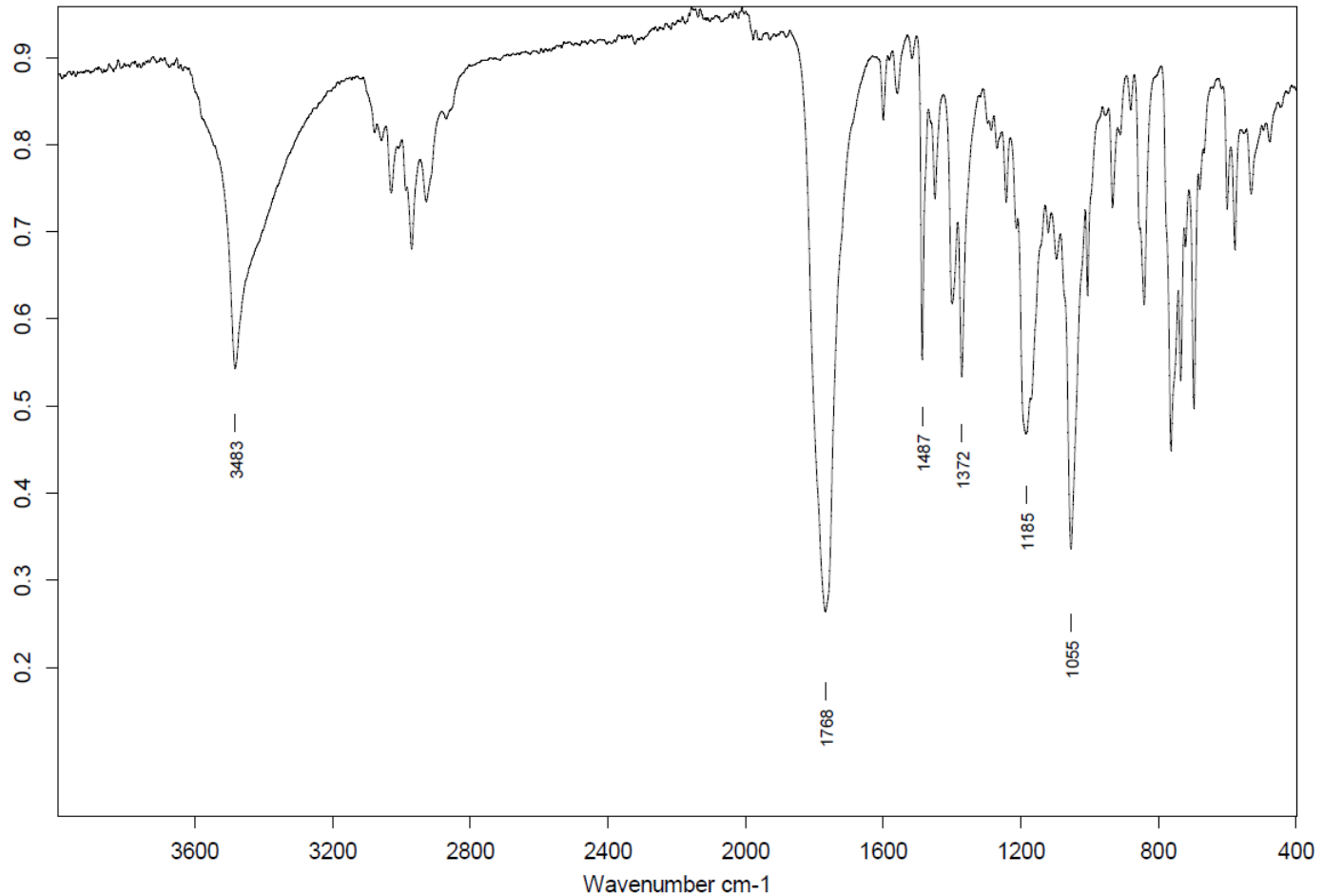




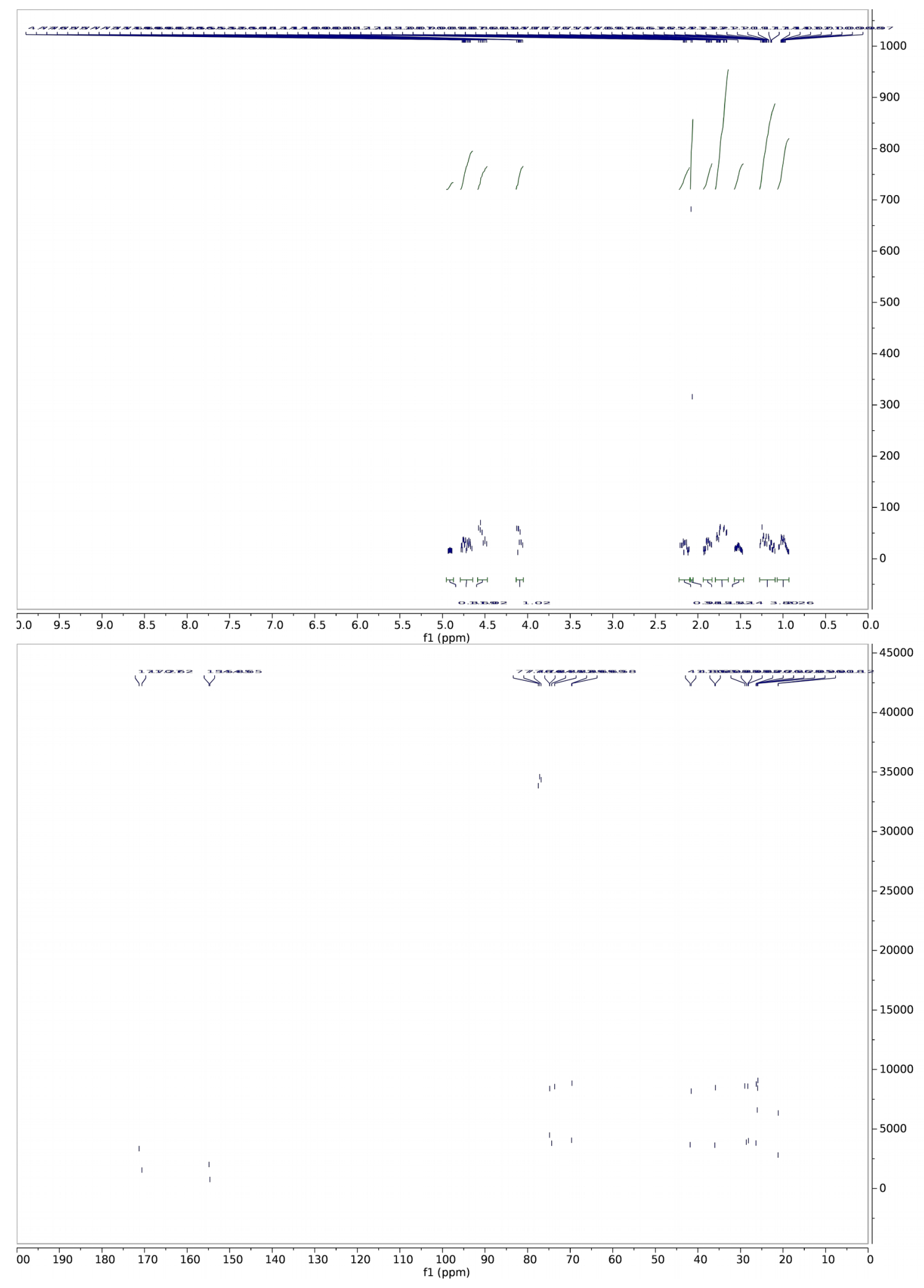




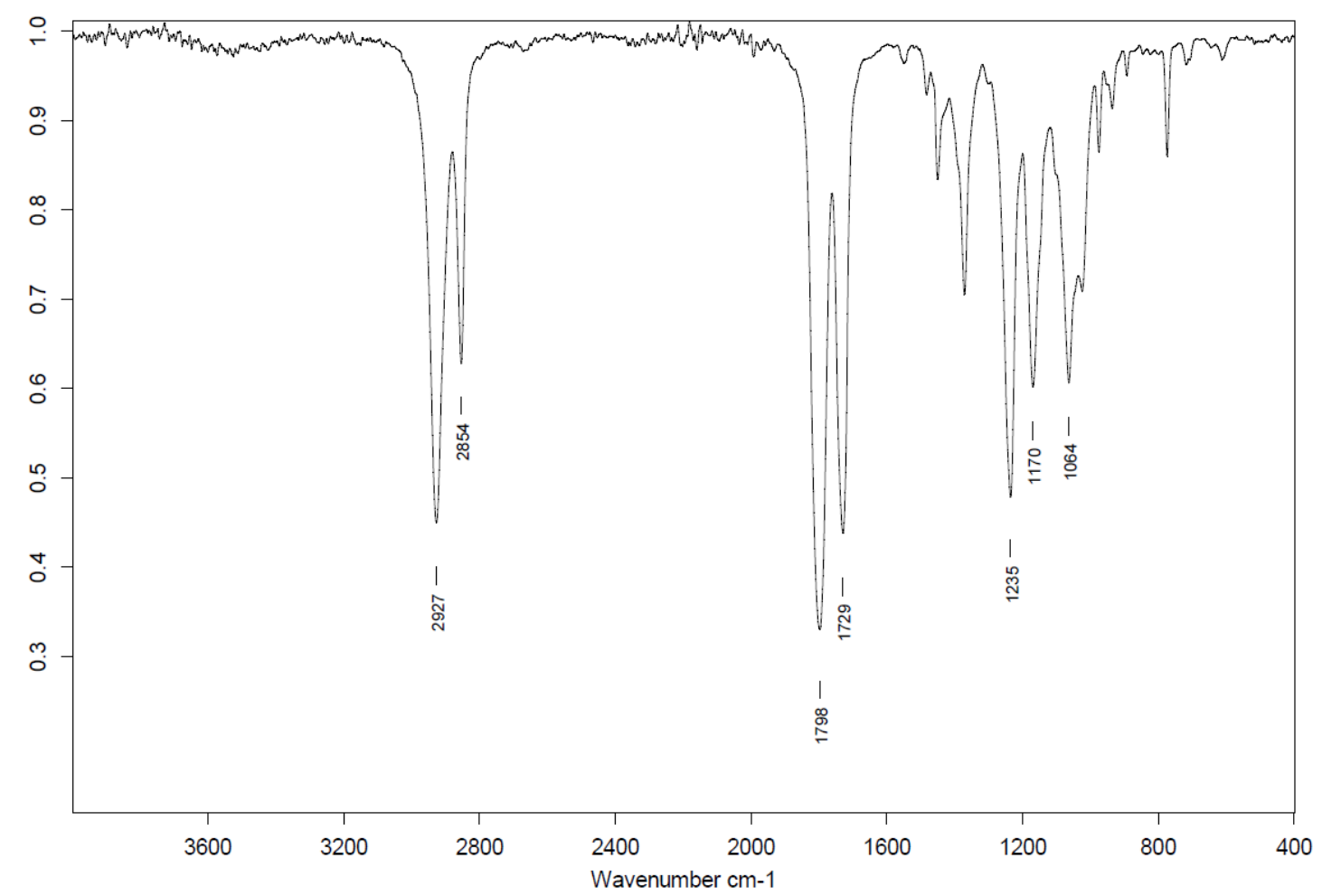




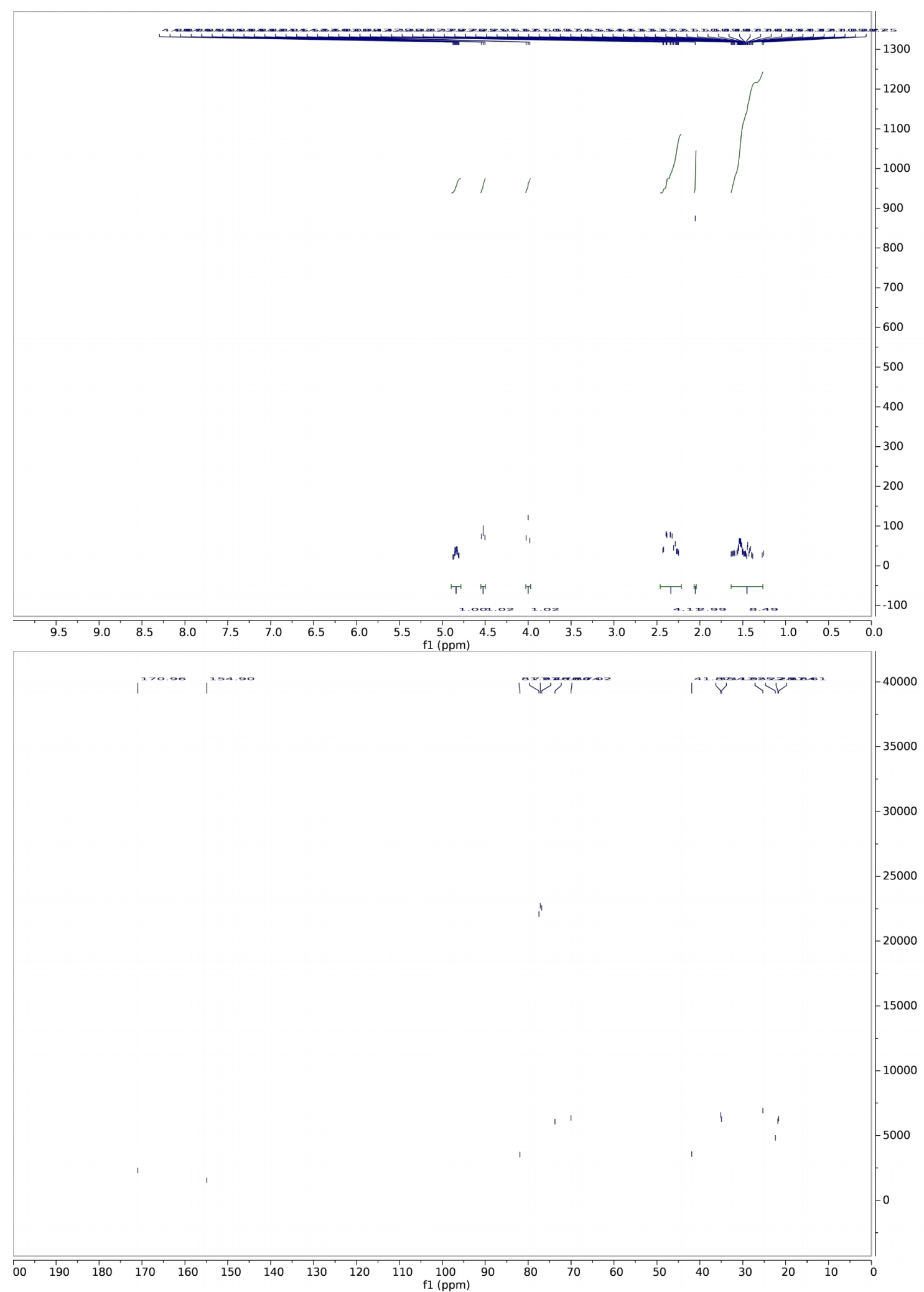




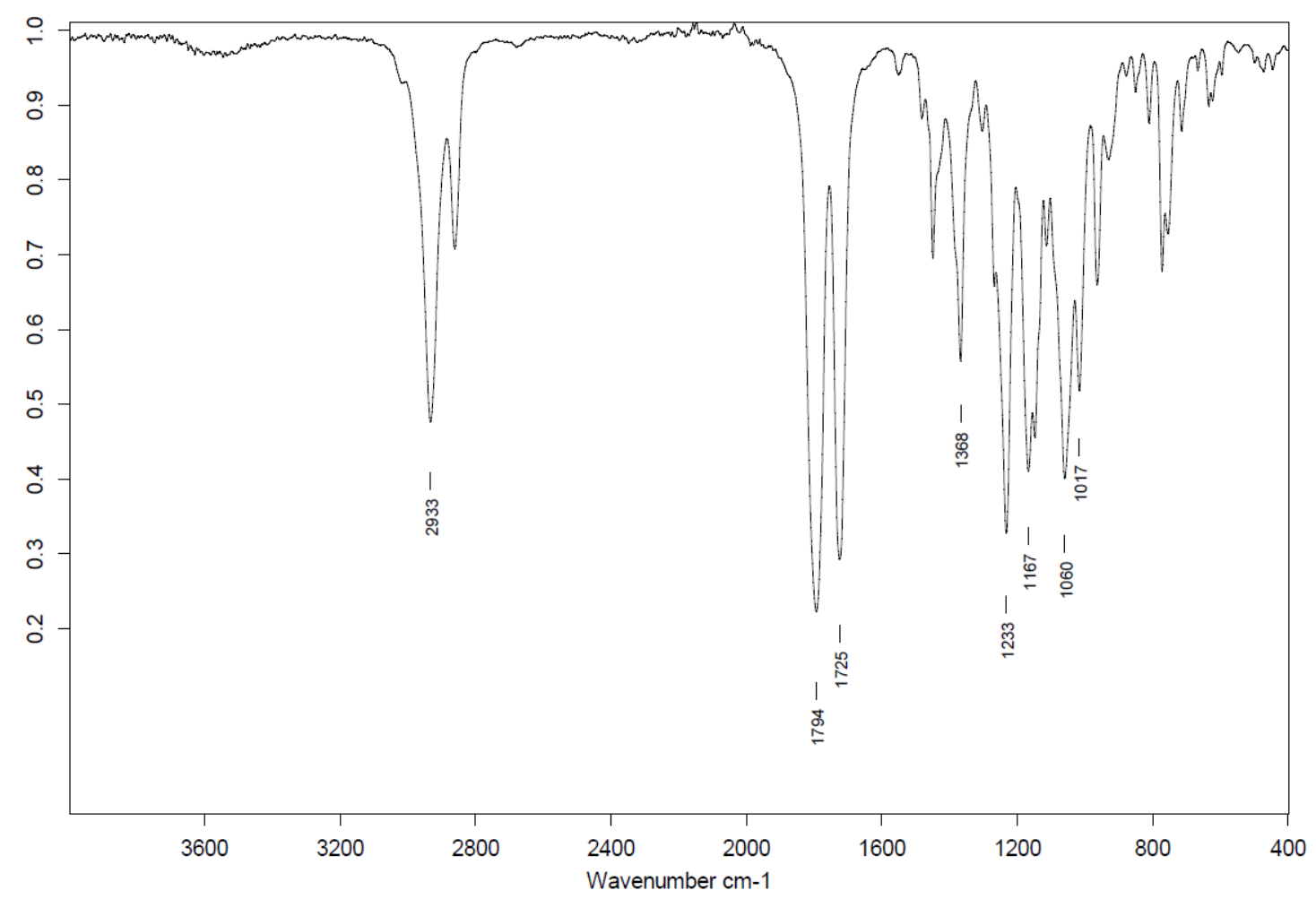


Spectra for 6-membered cyclic carbonate products 2a-2q: 

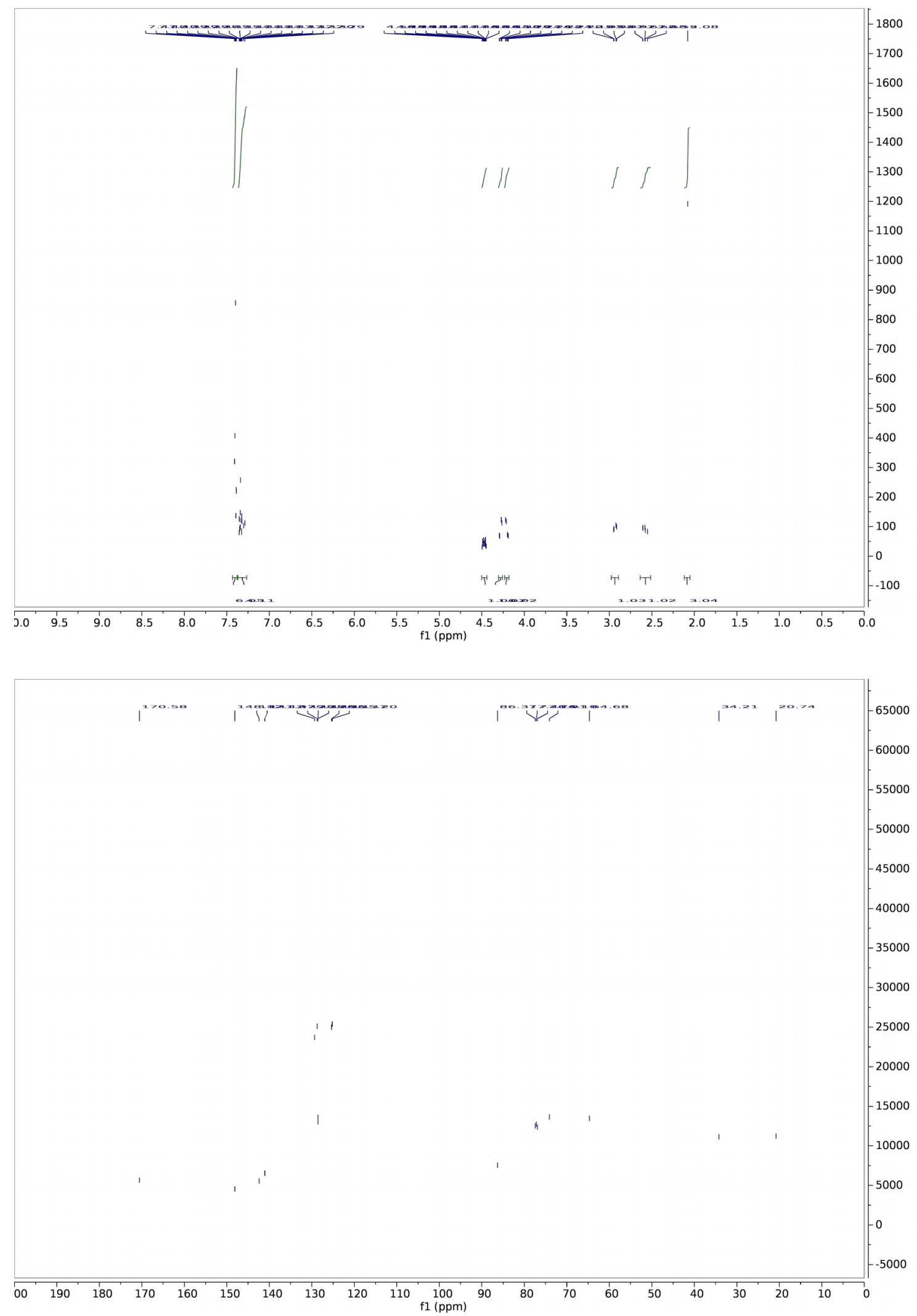


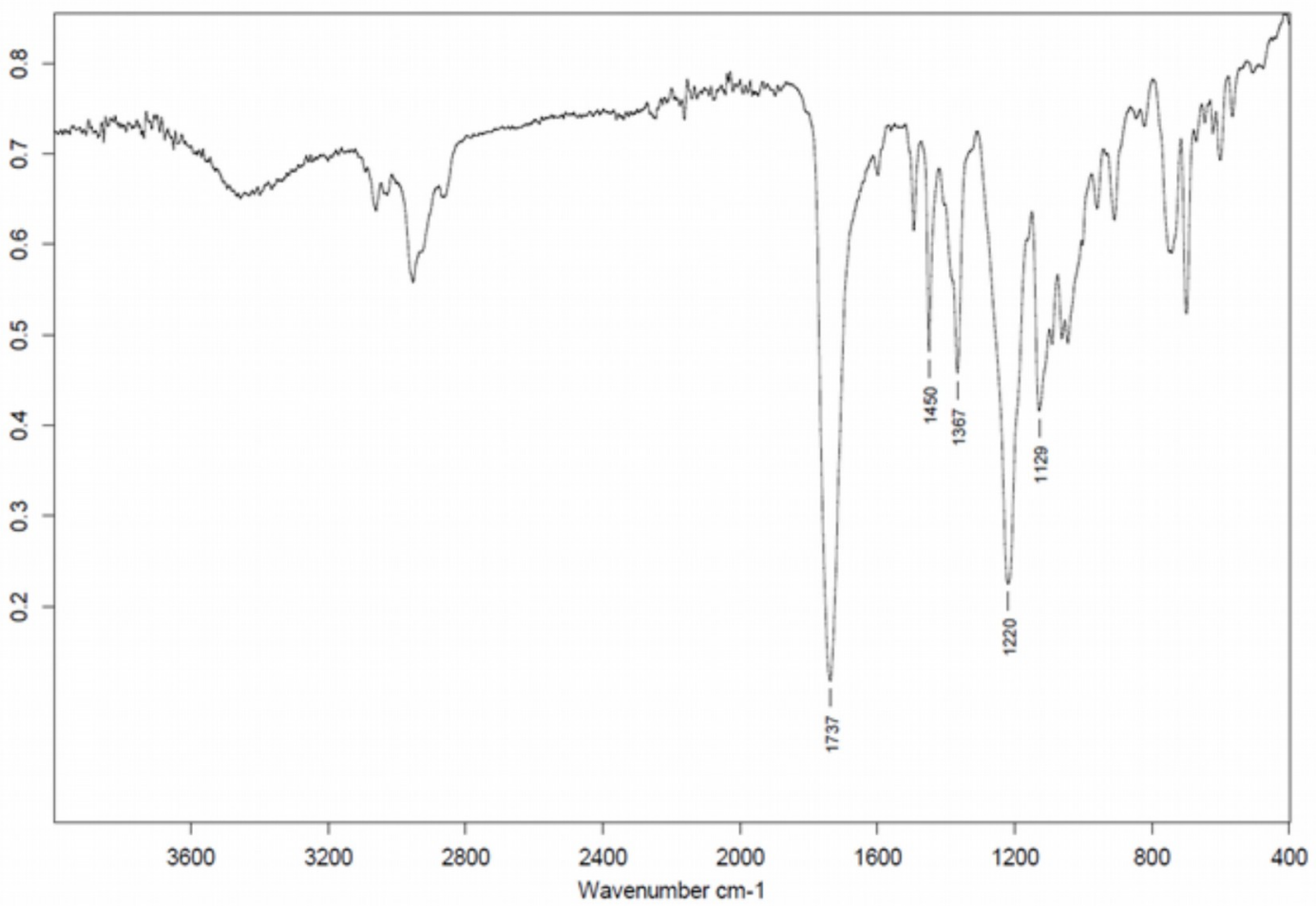



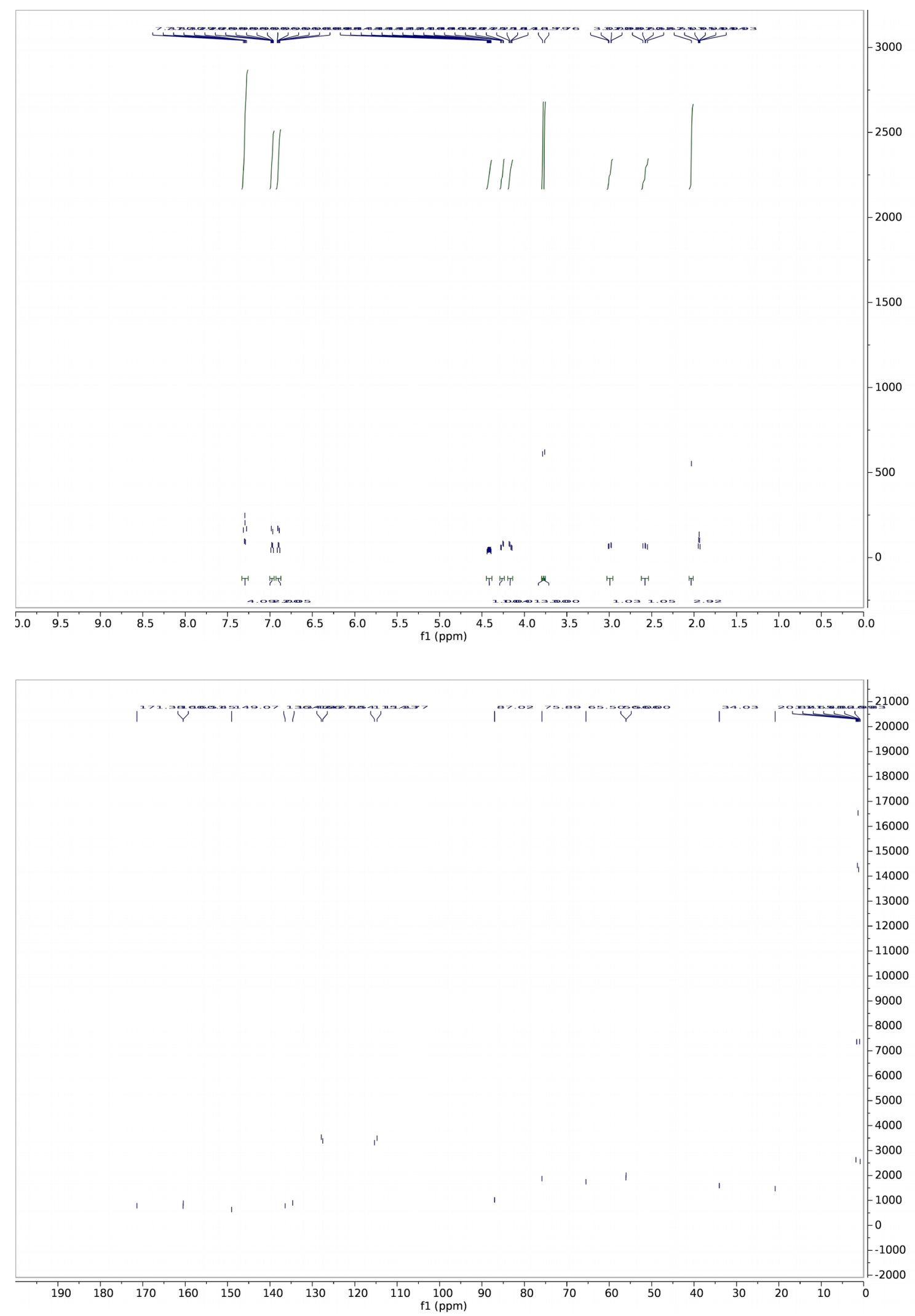


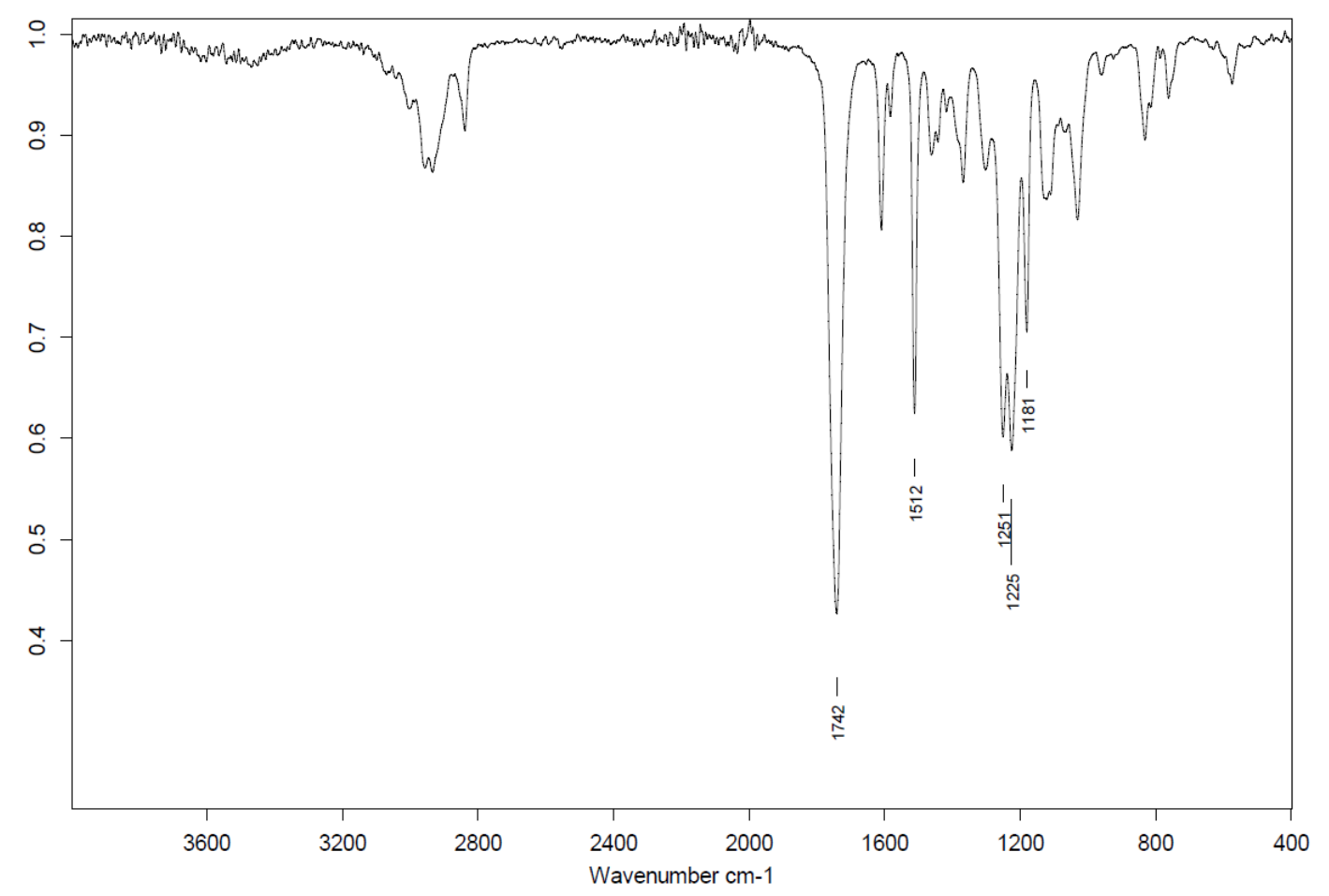



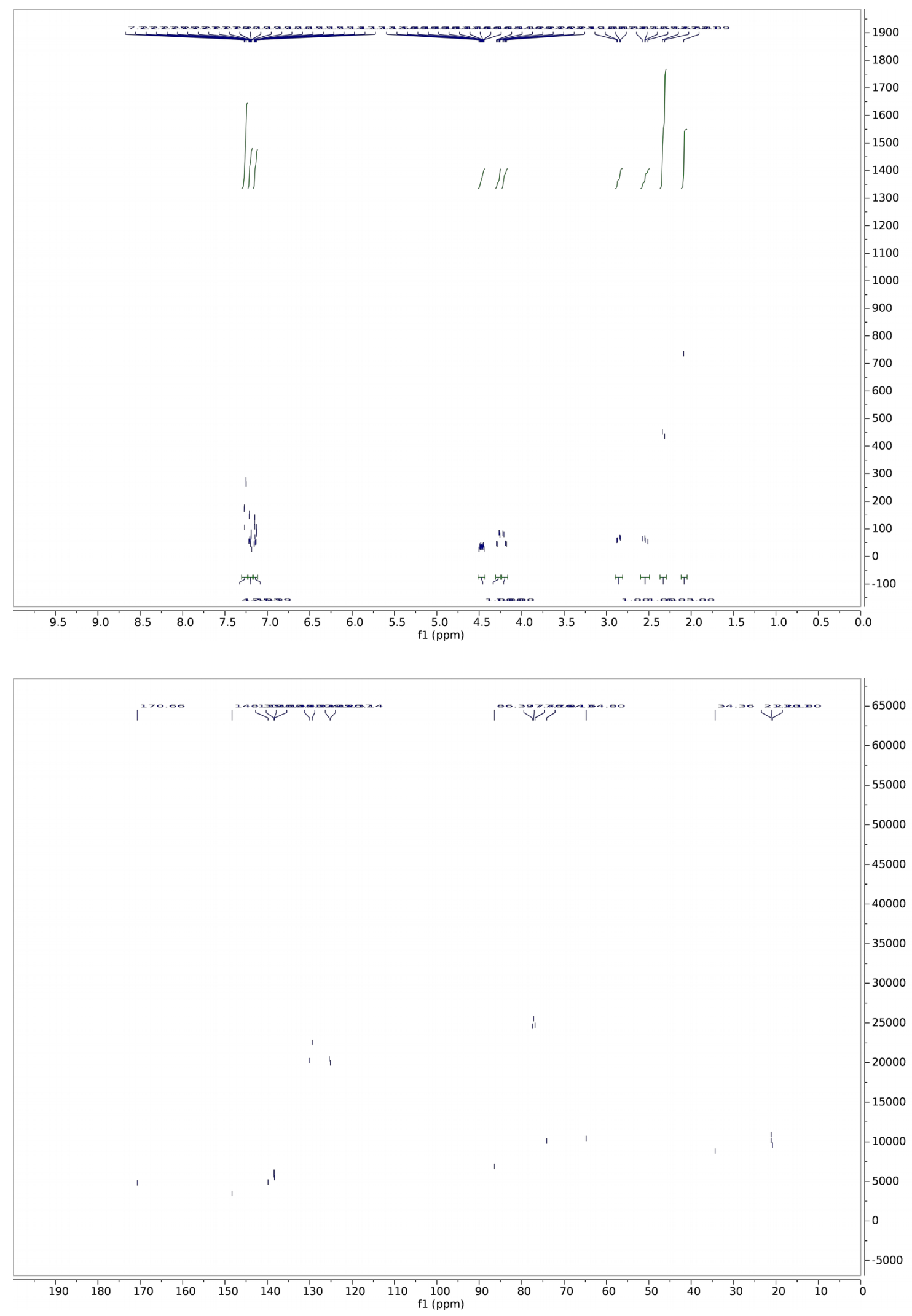


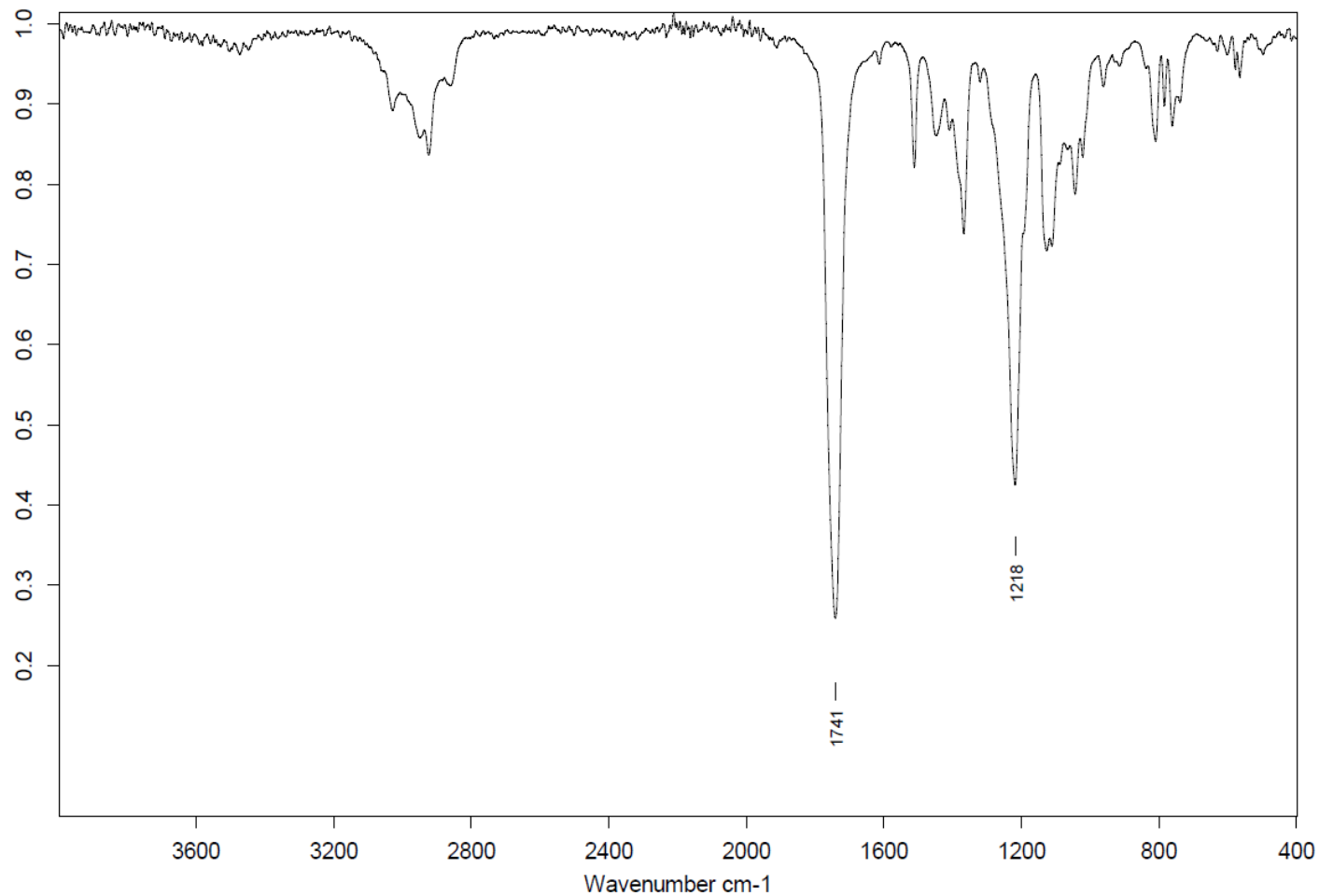




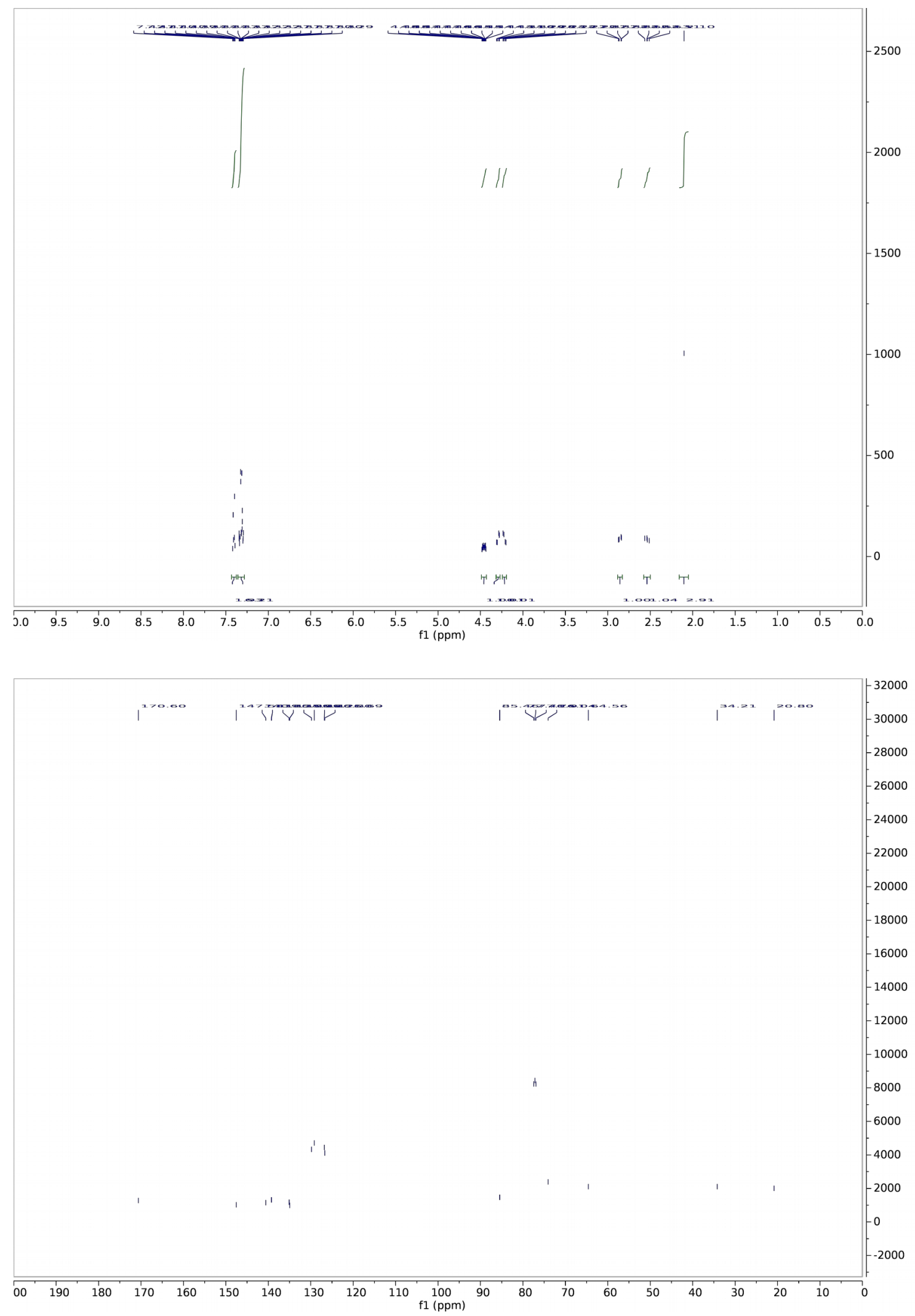




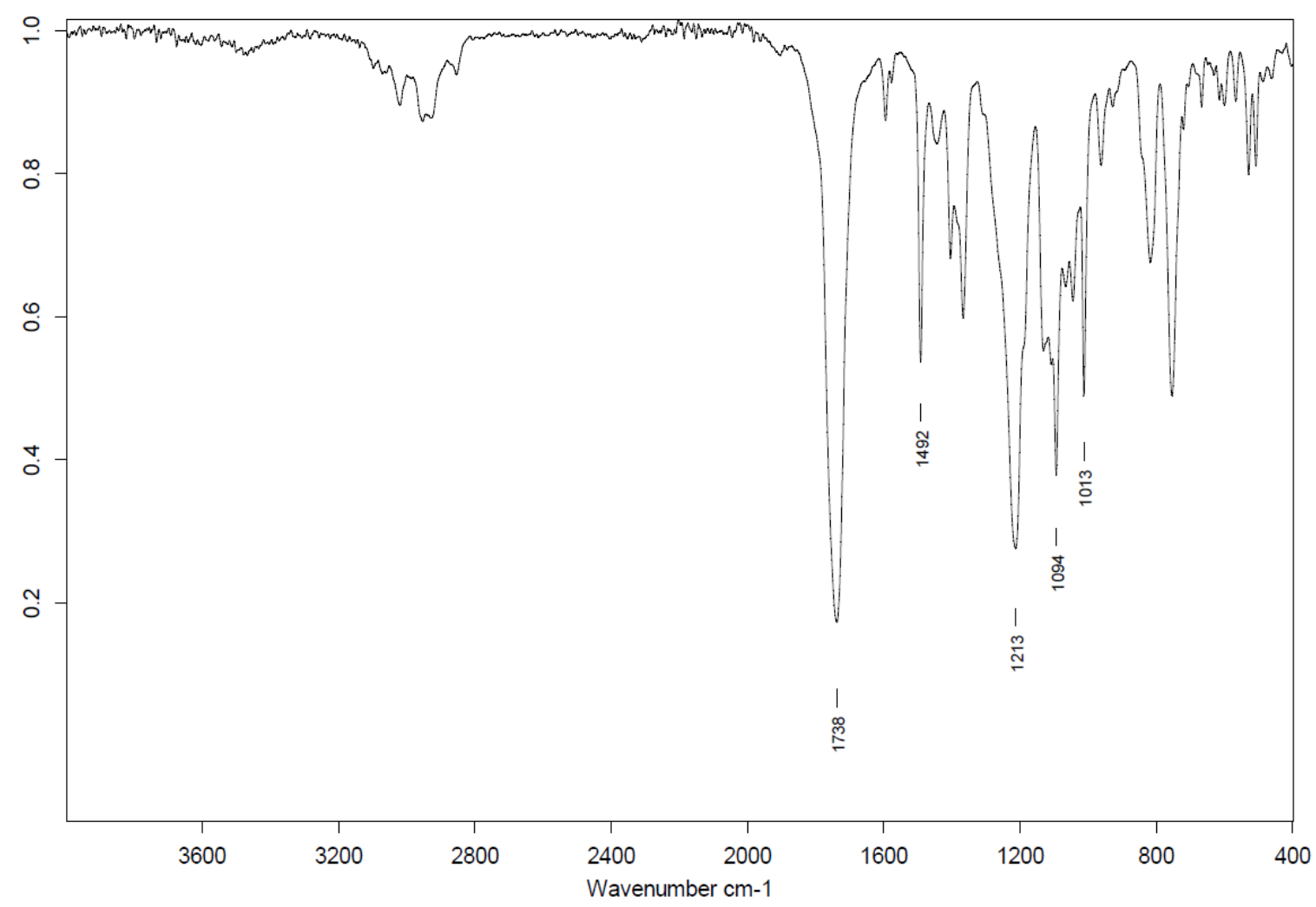



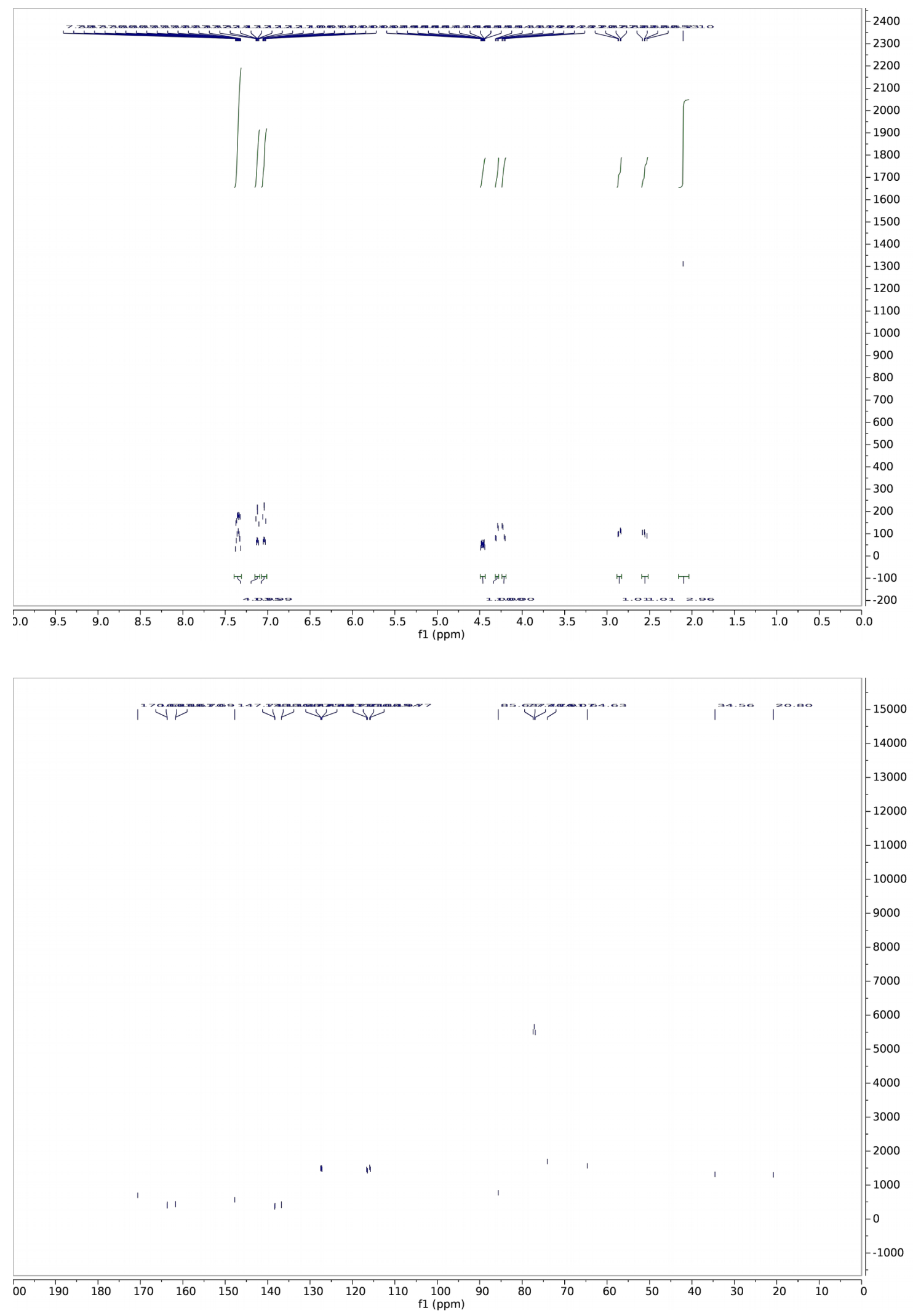

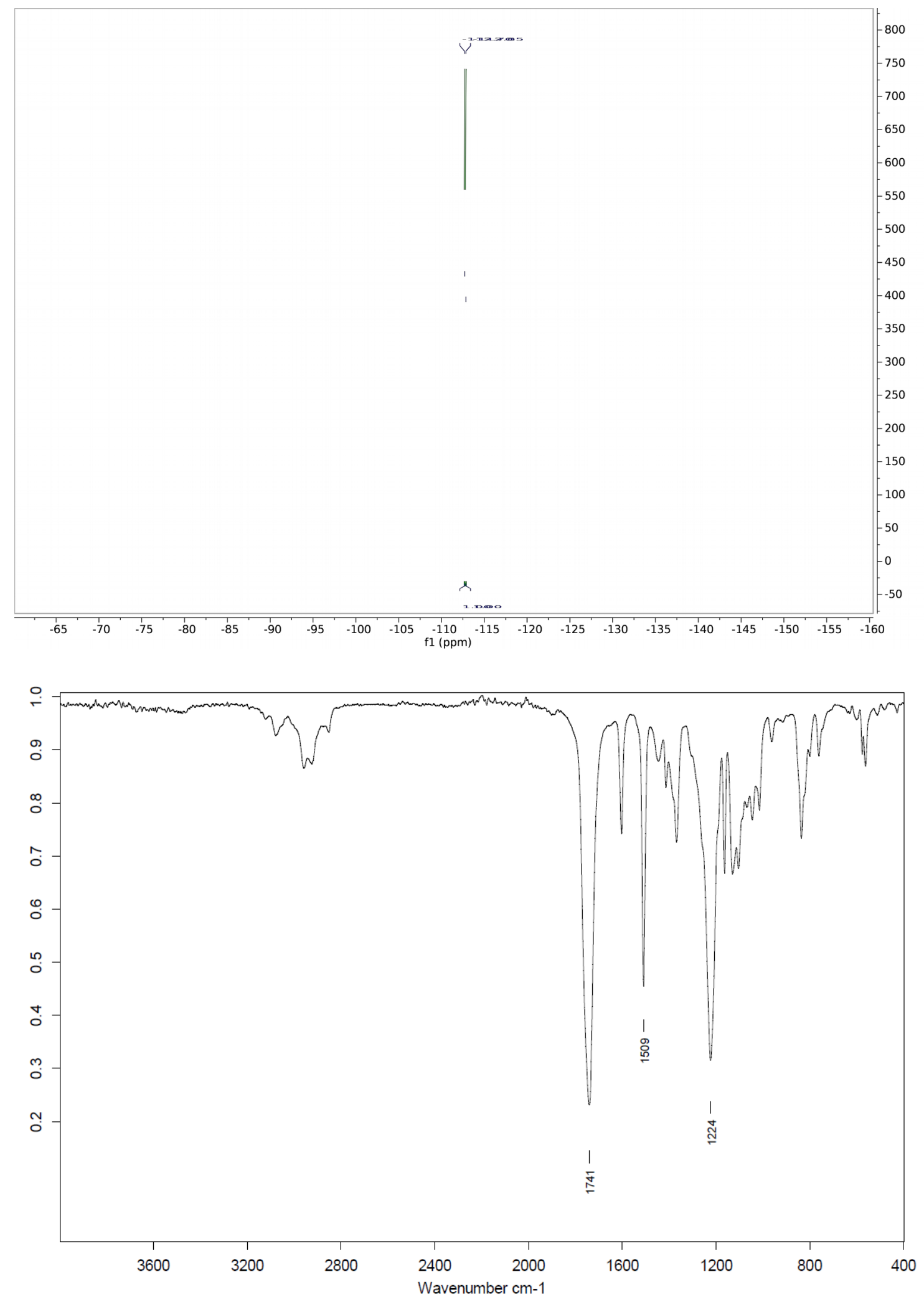


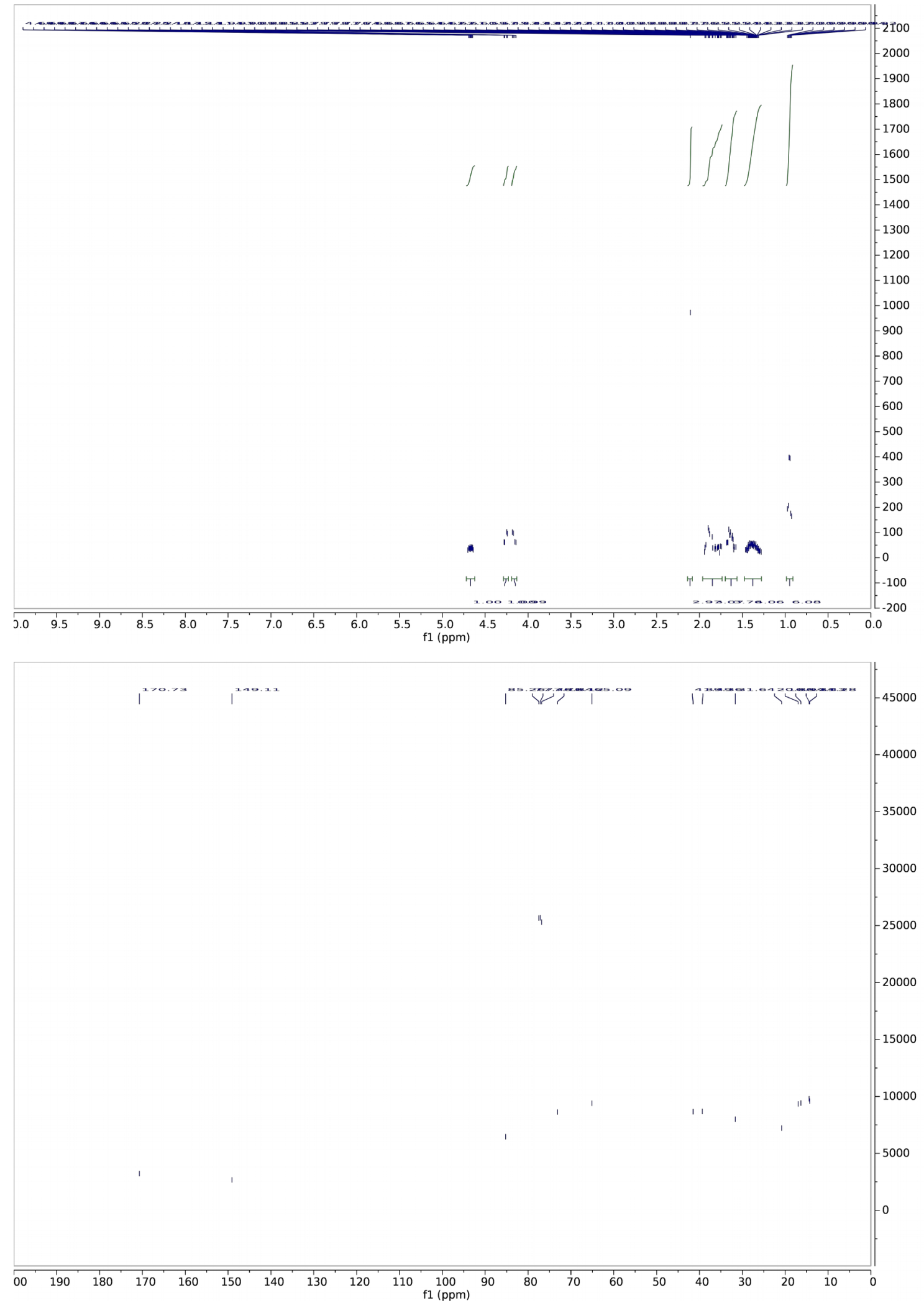




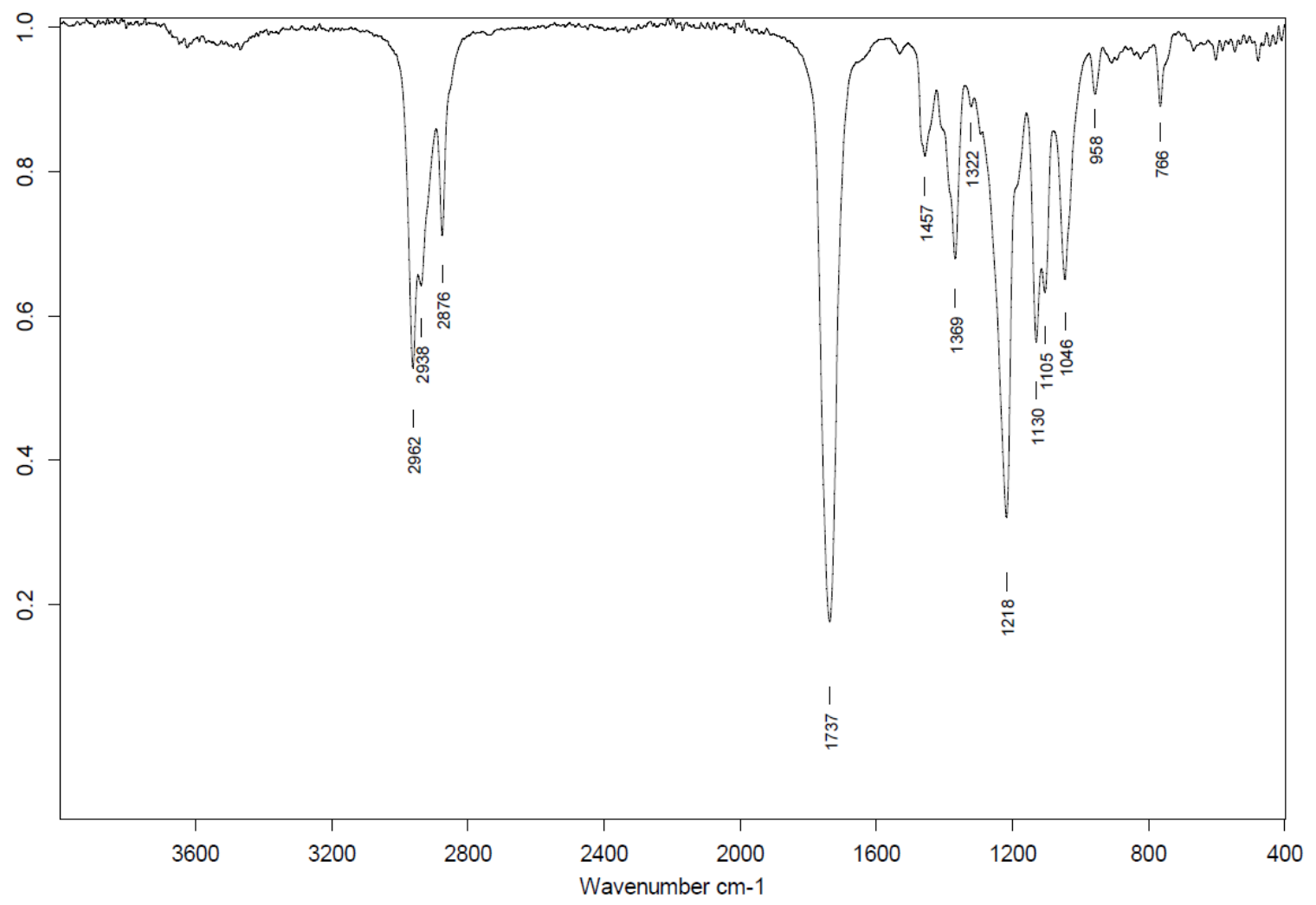




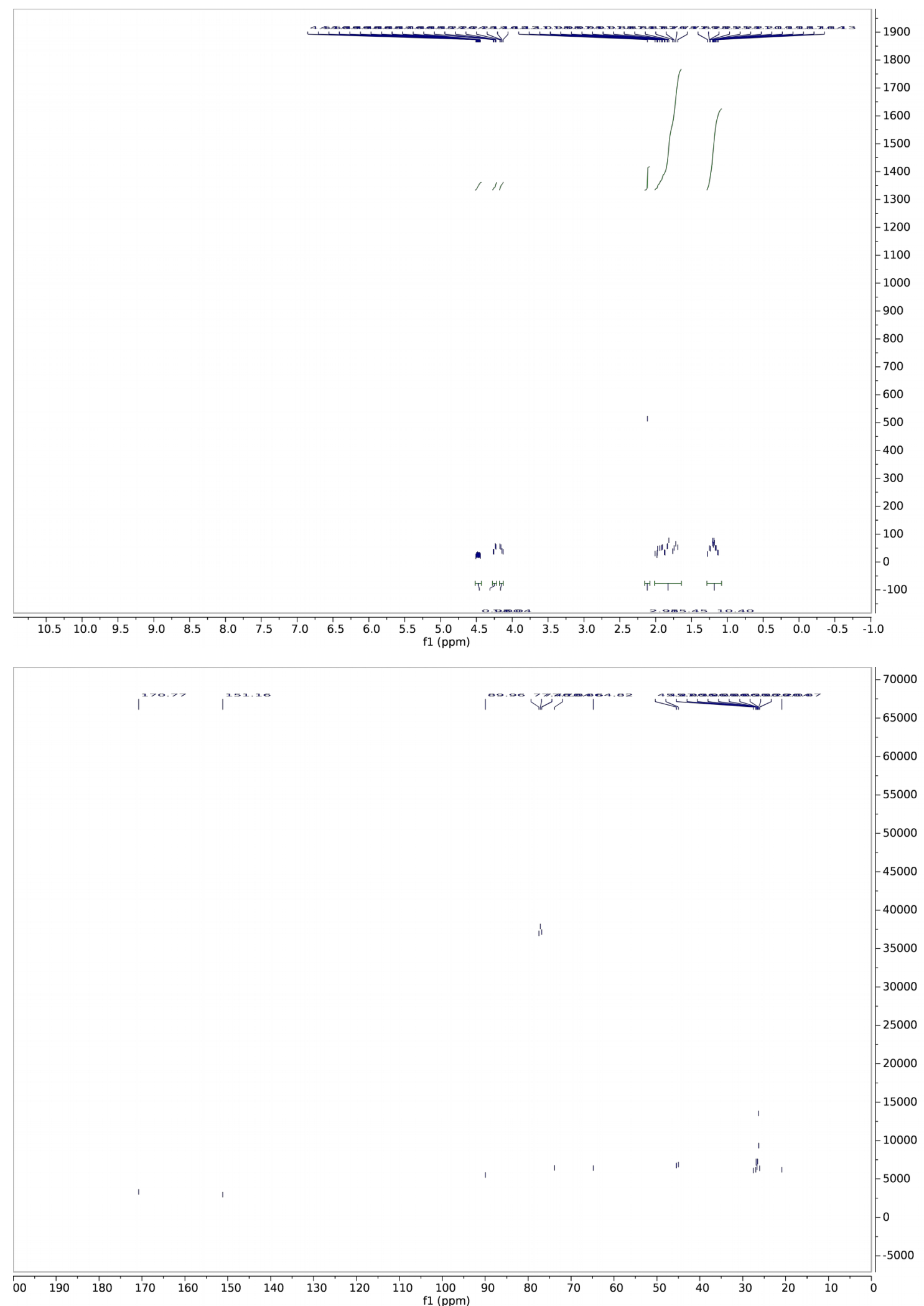




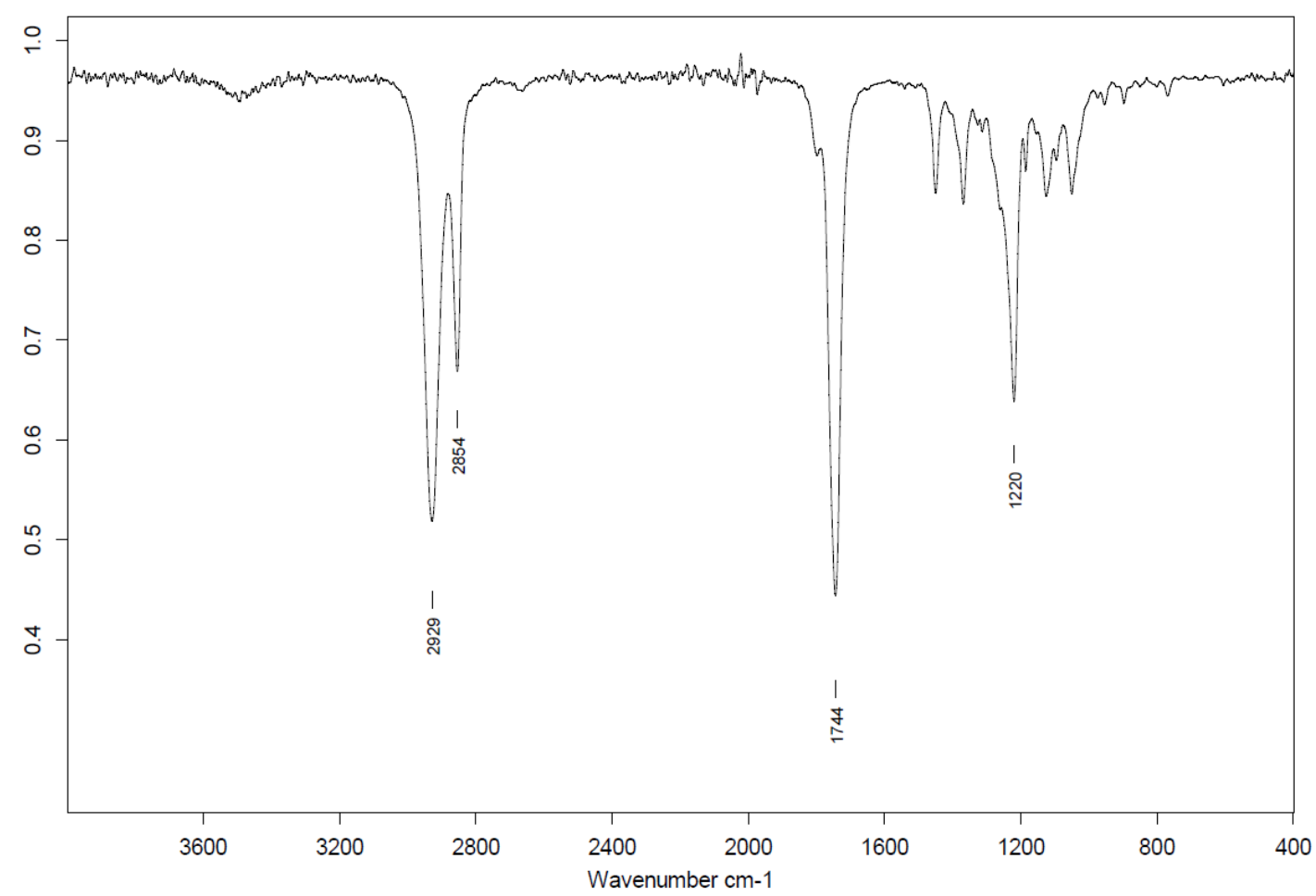



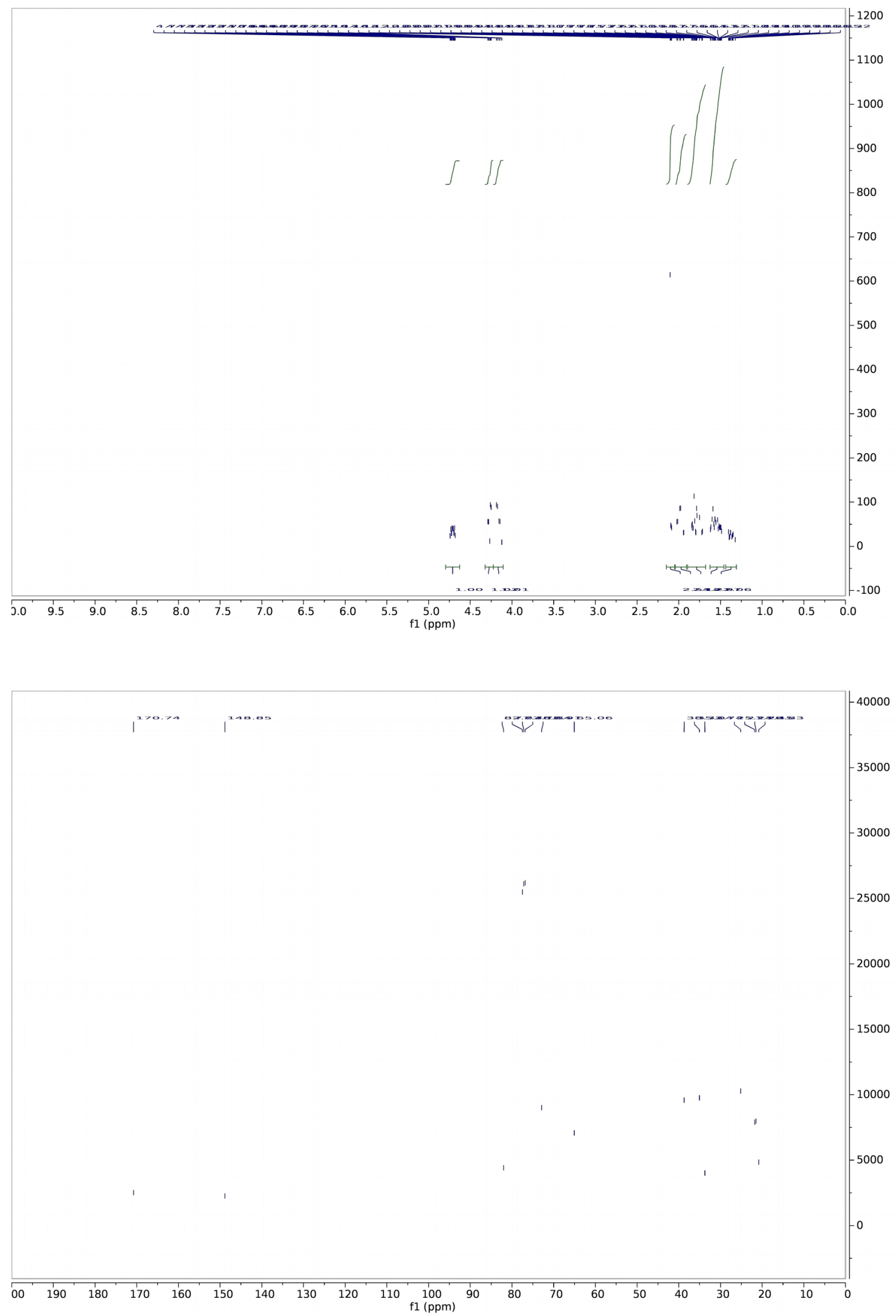


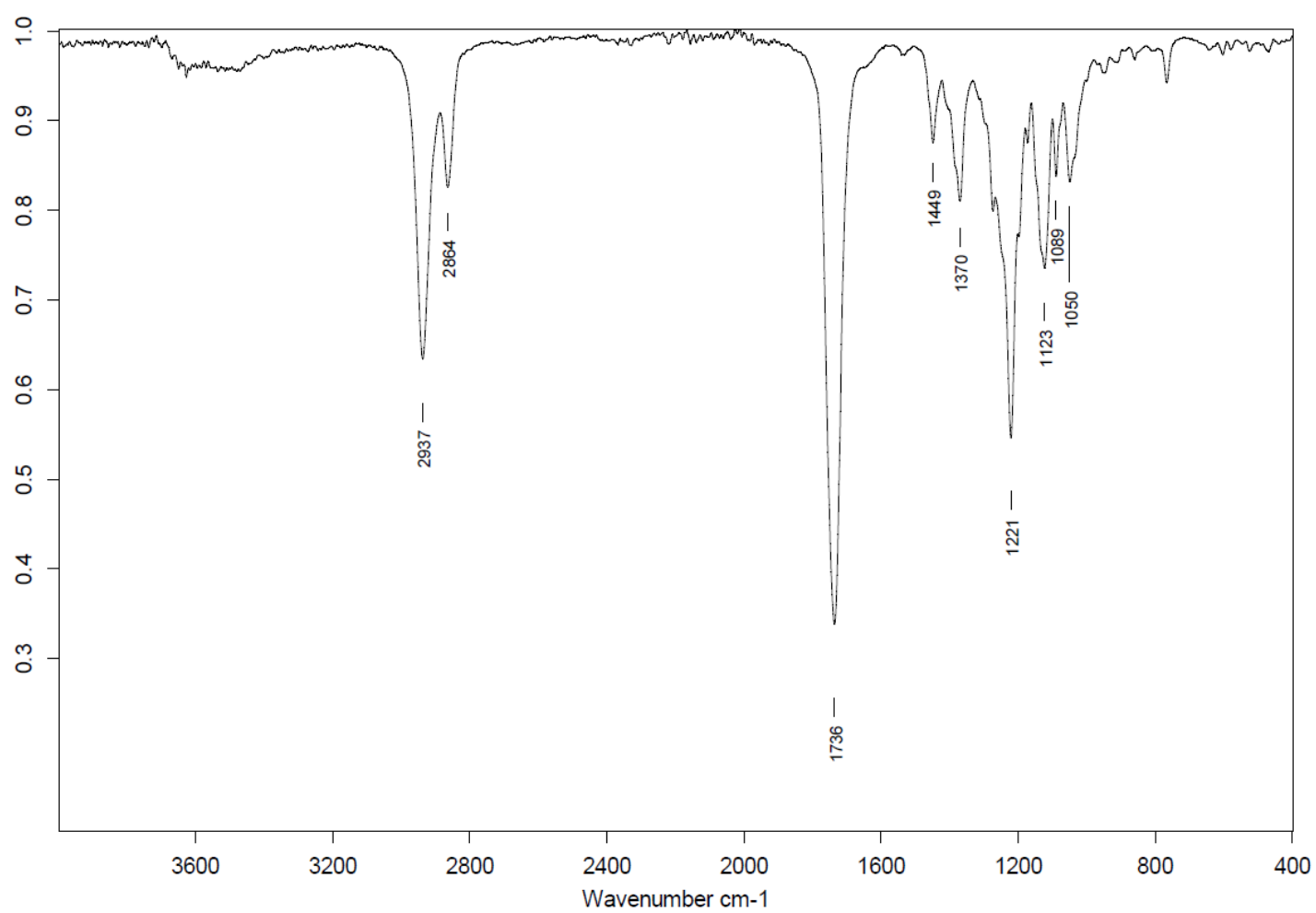




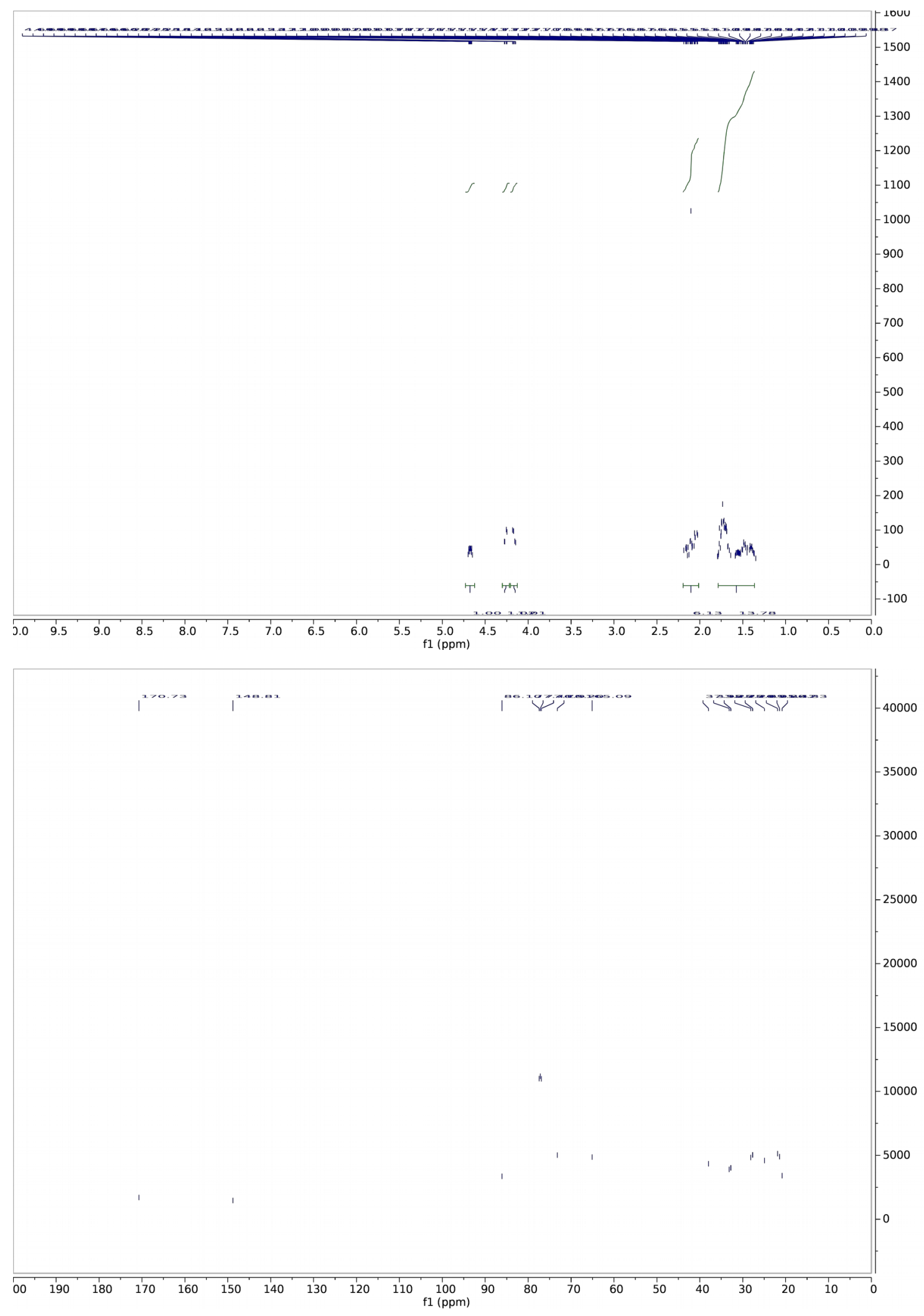




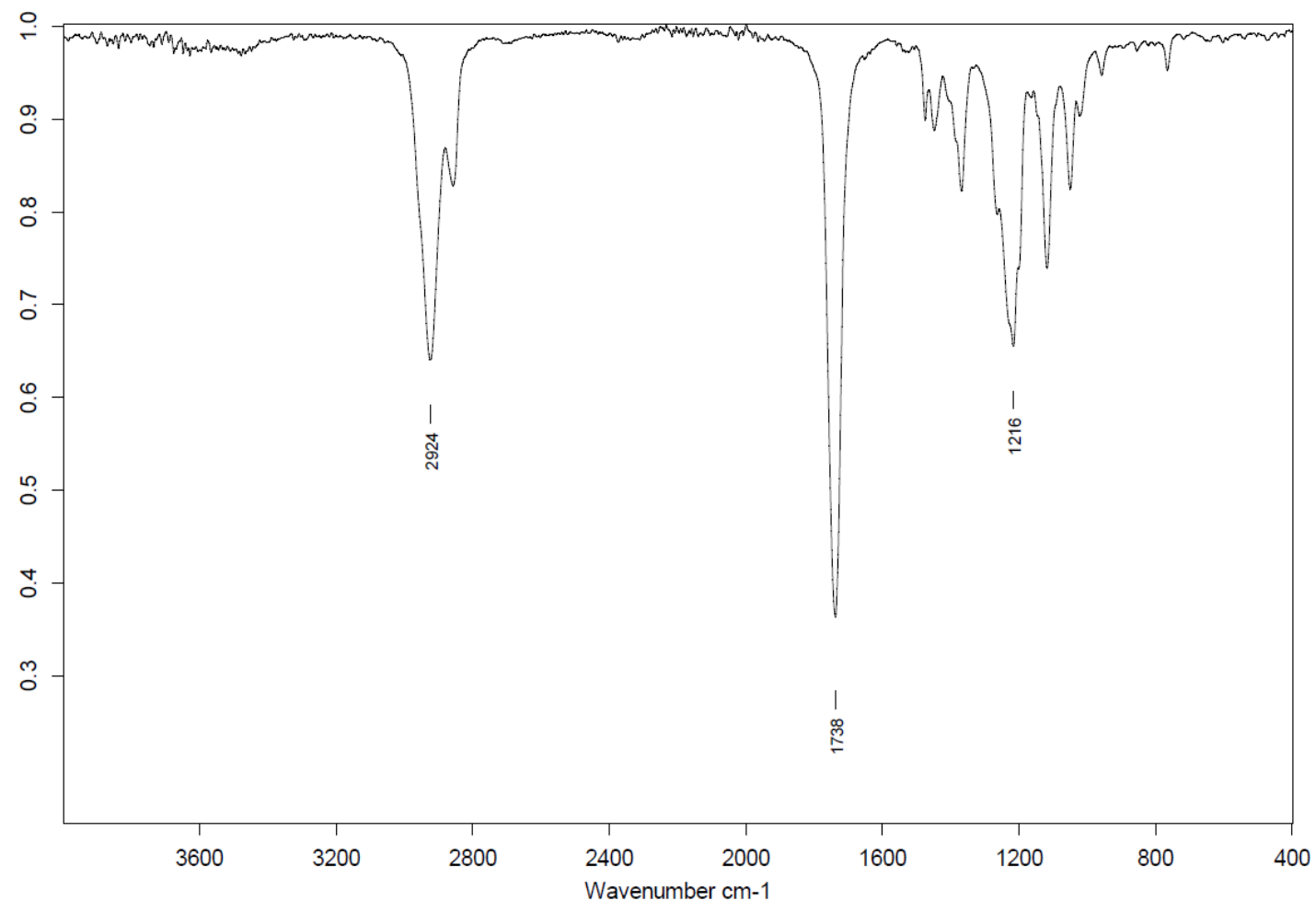



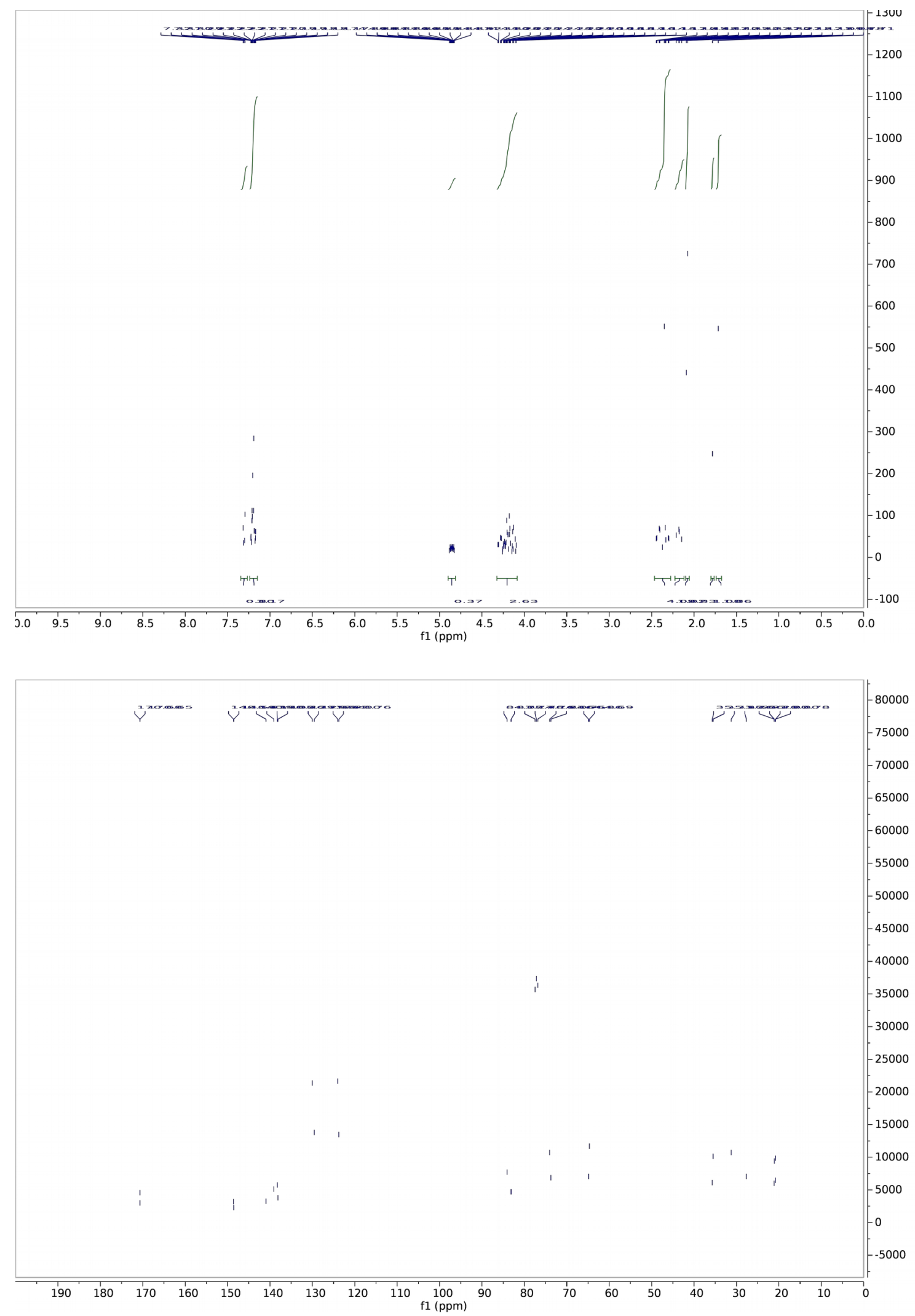


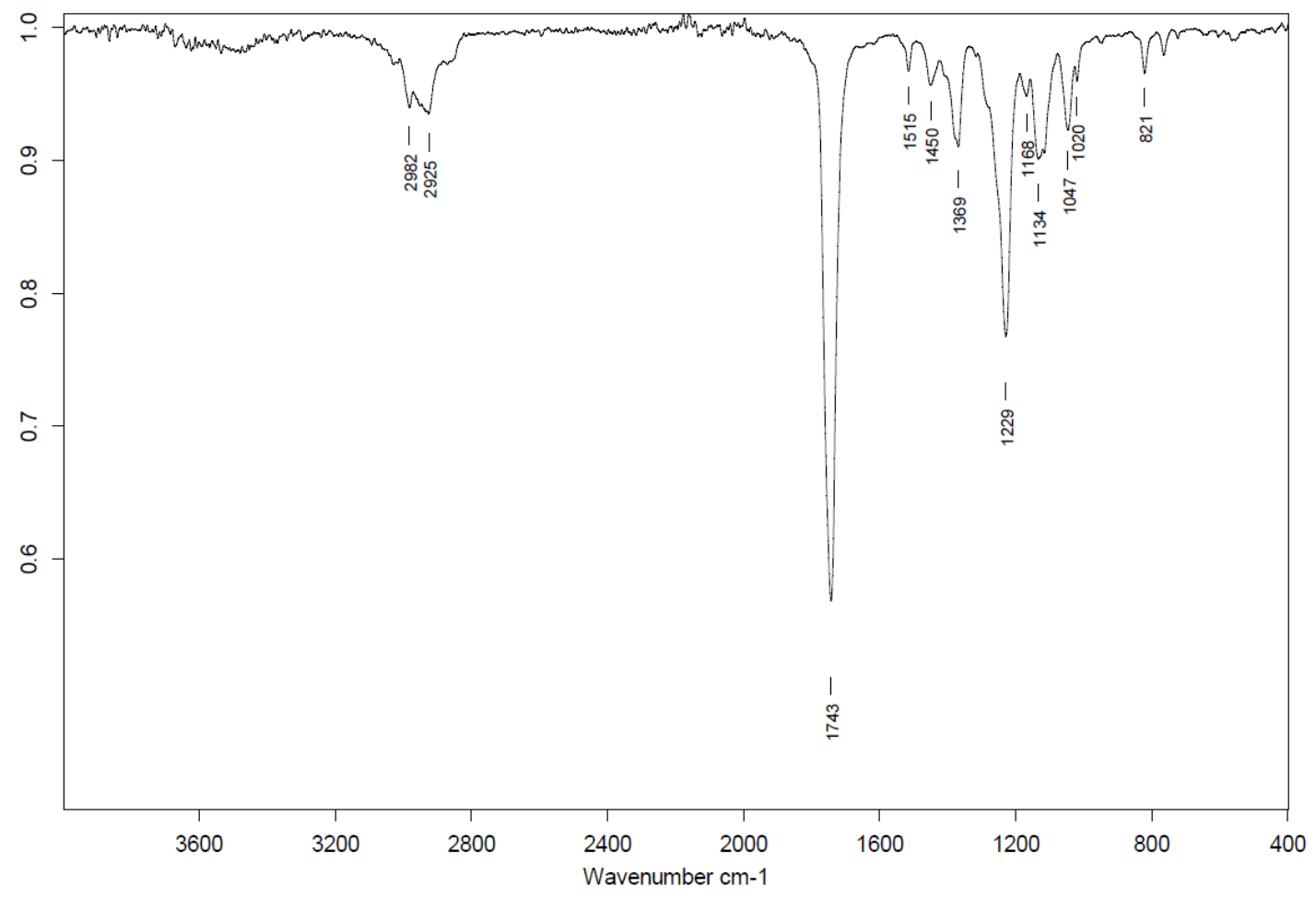




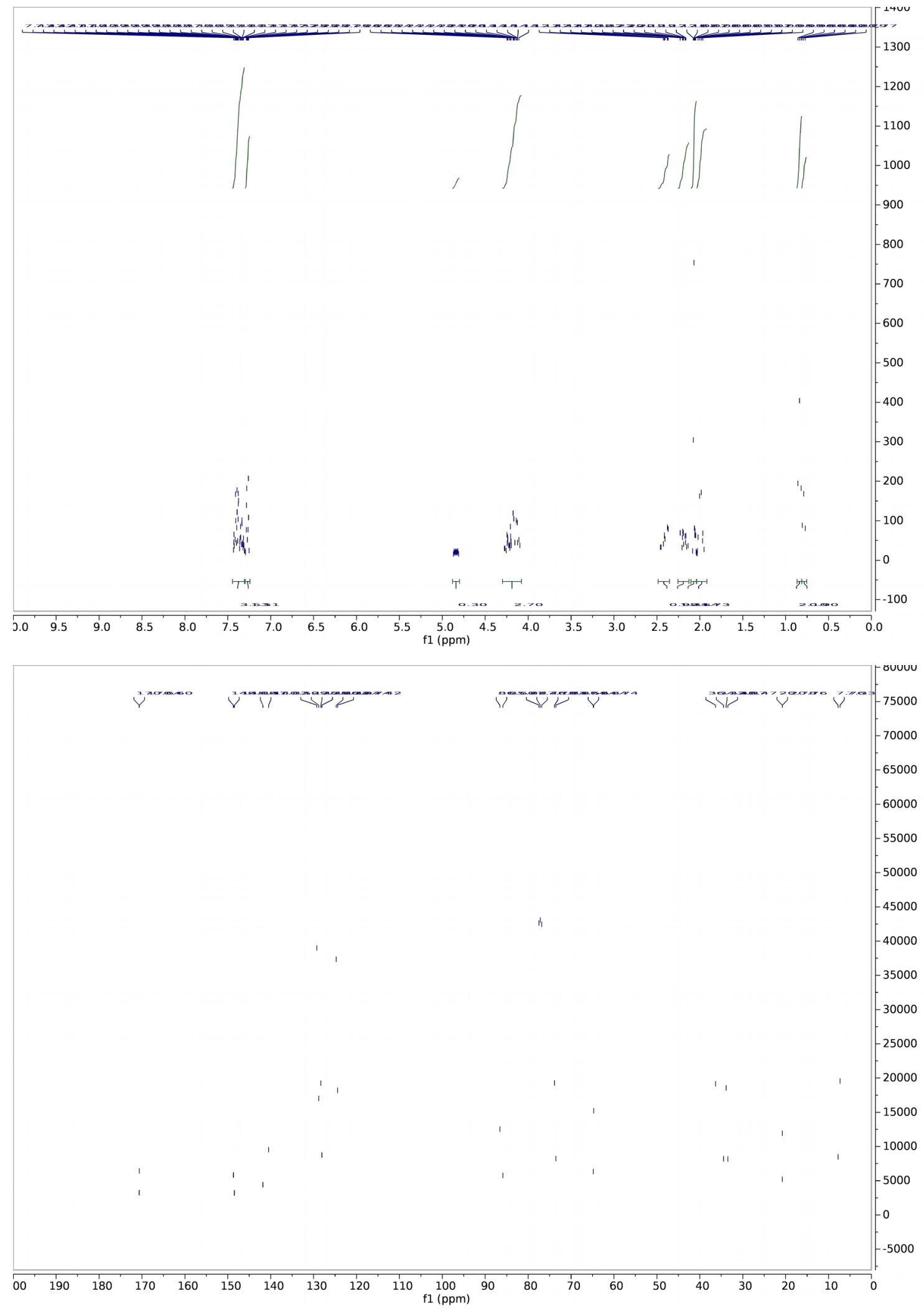




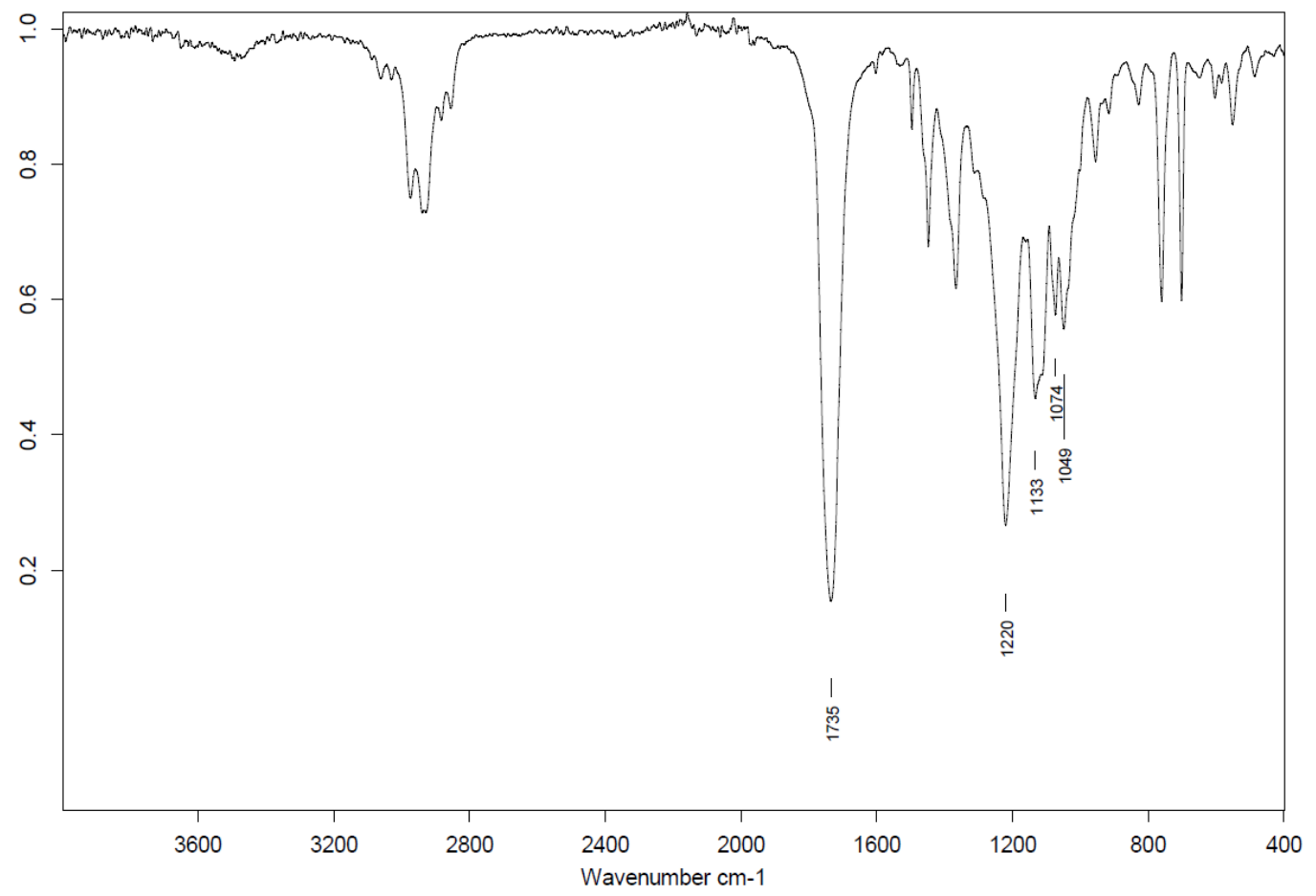



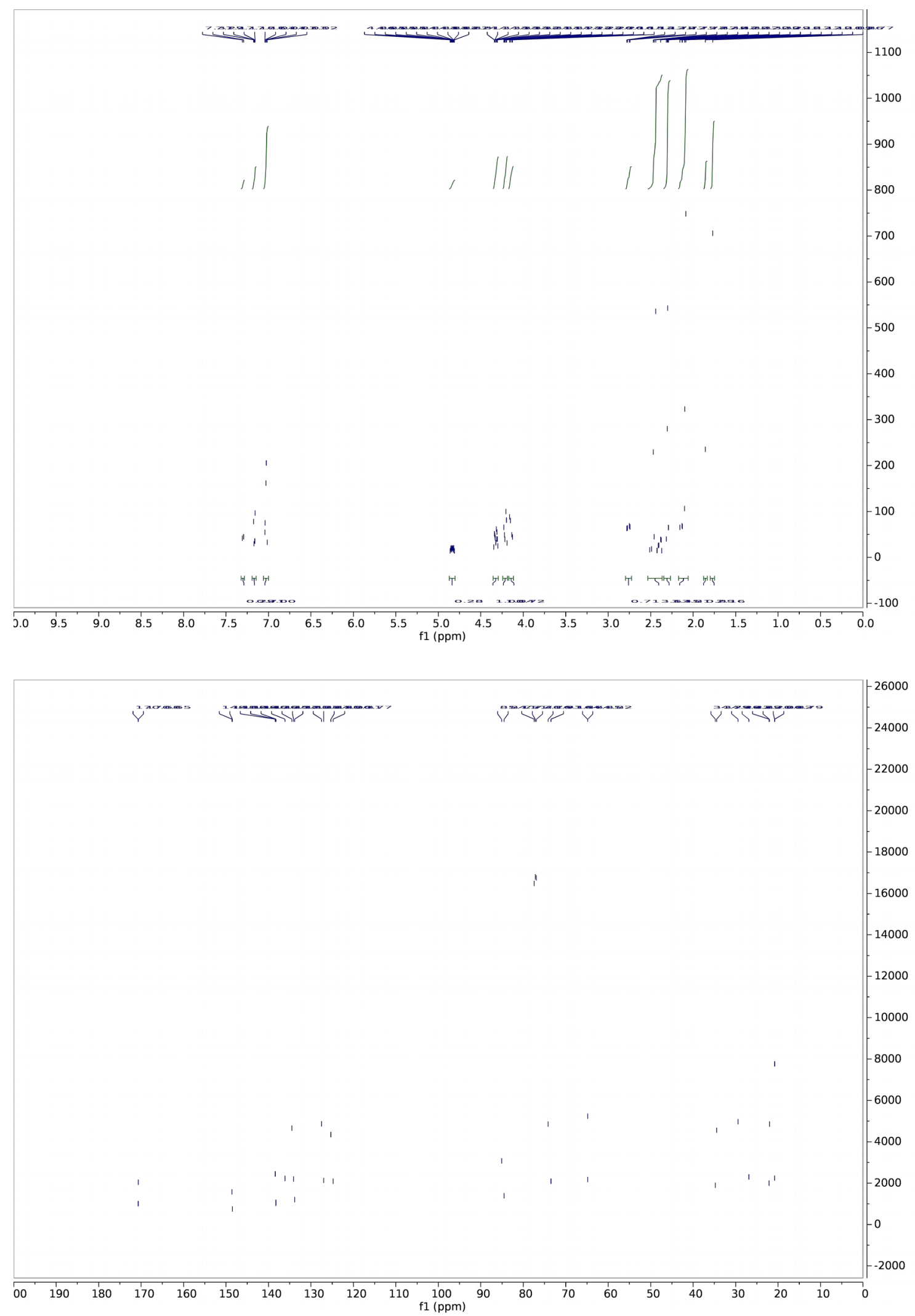


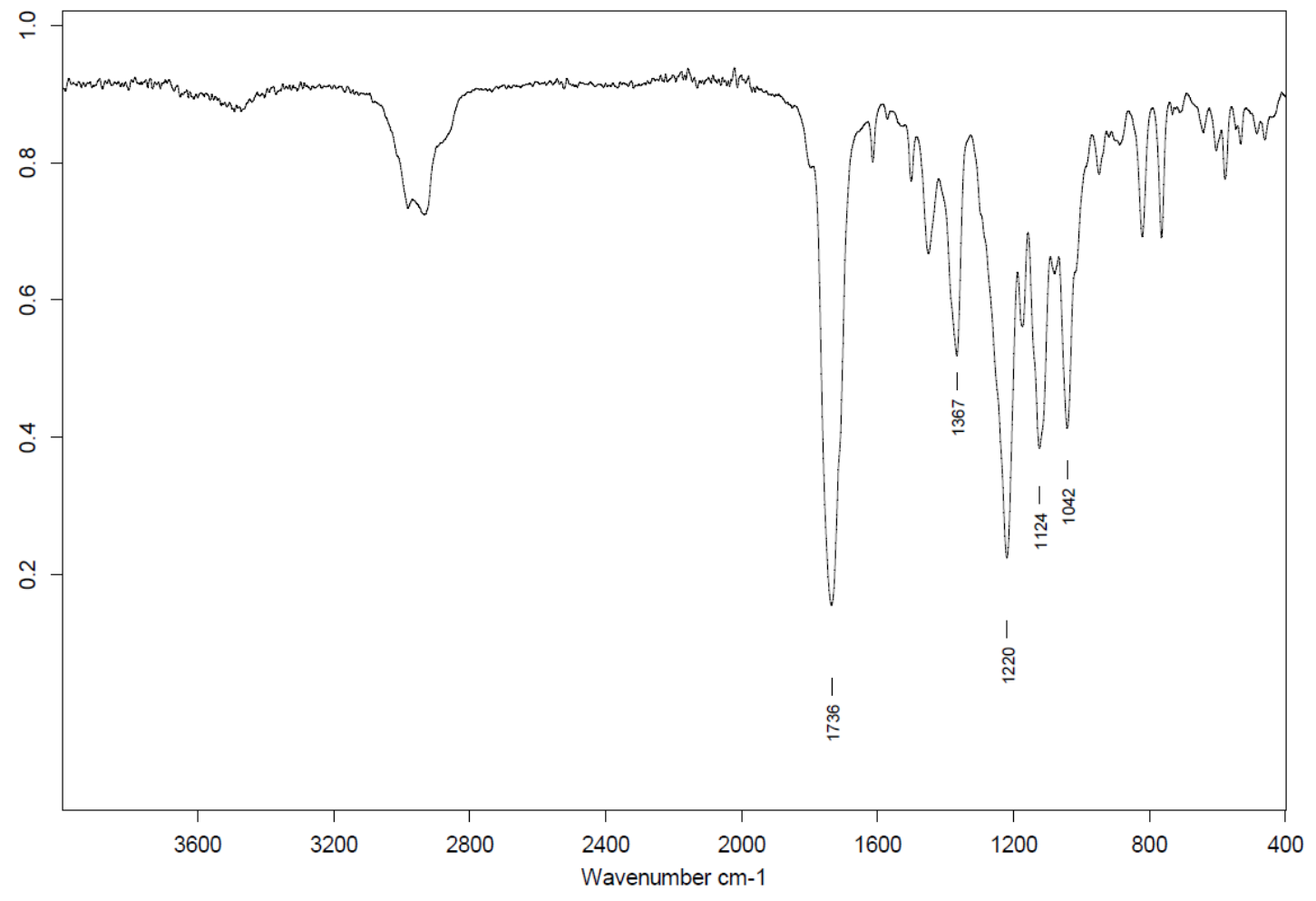



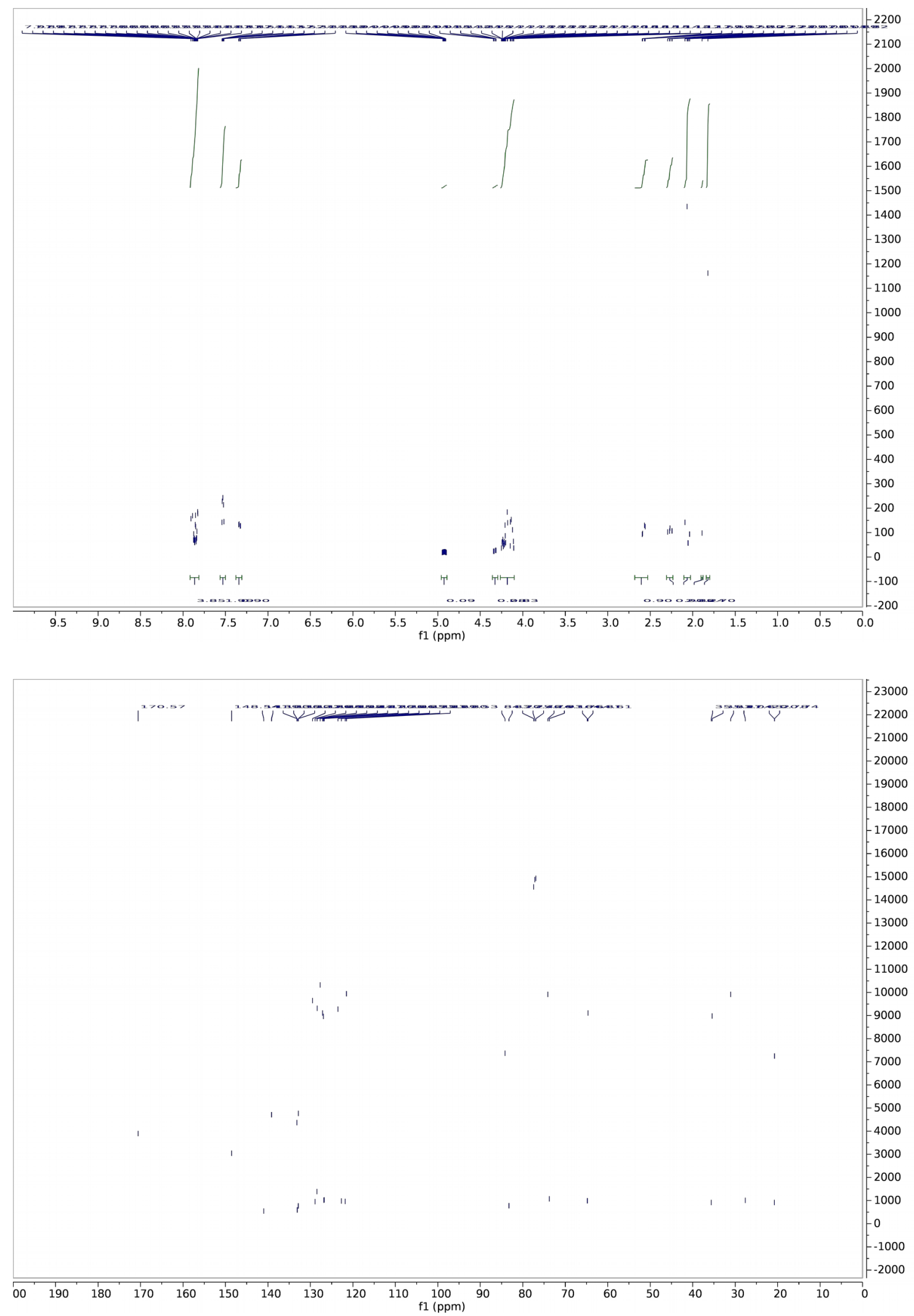


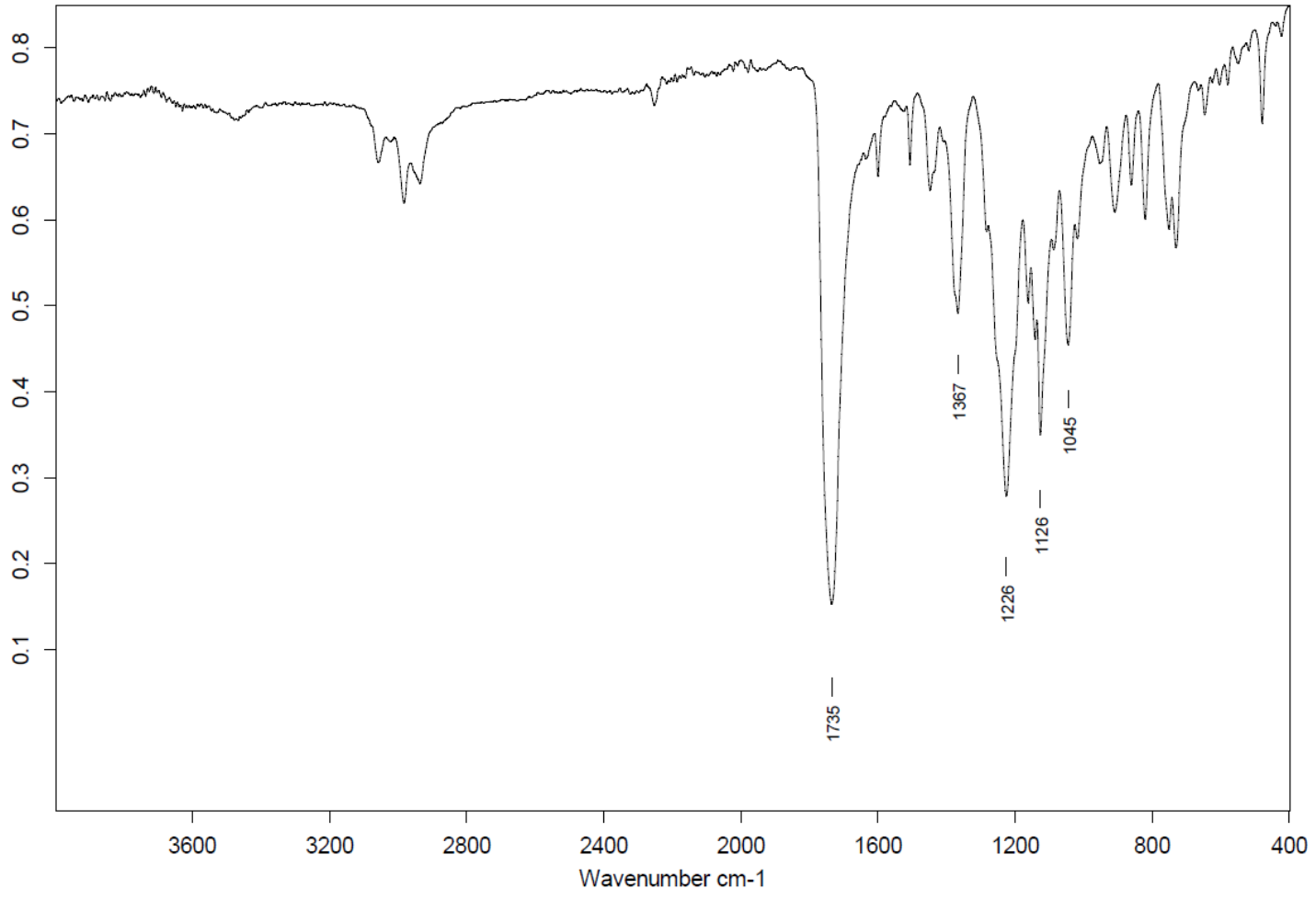



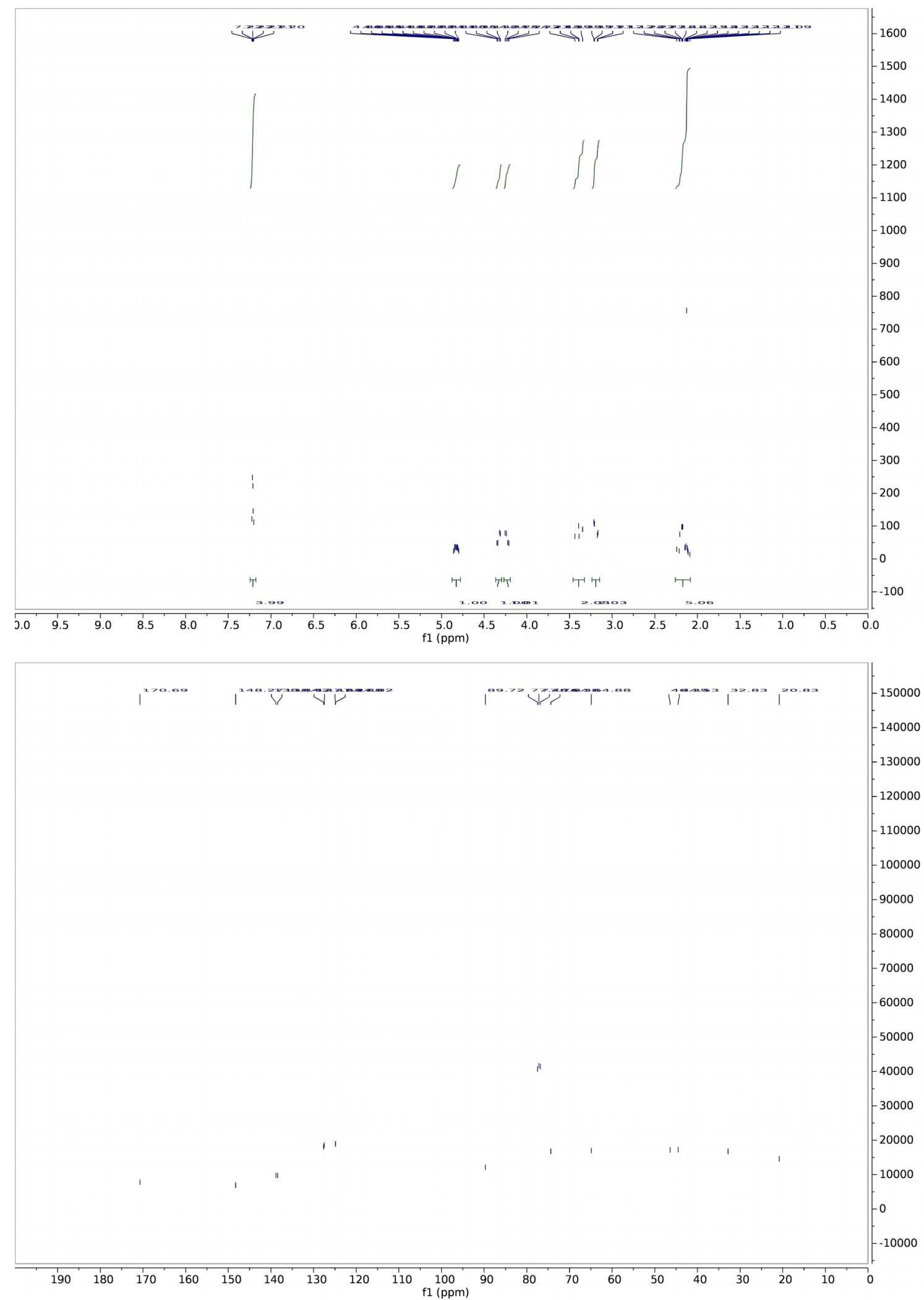


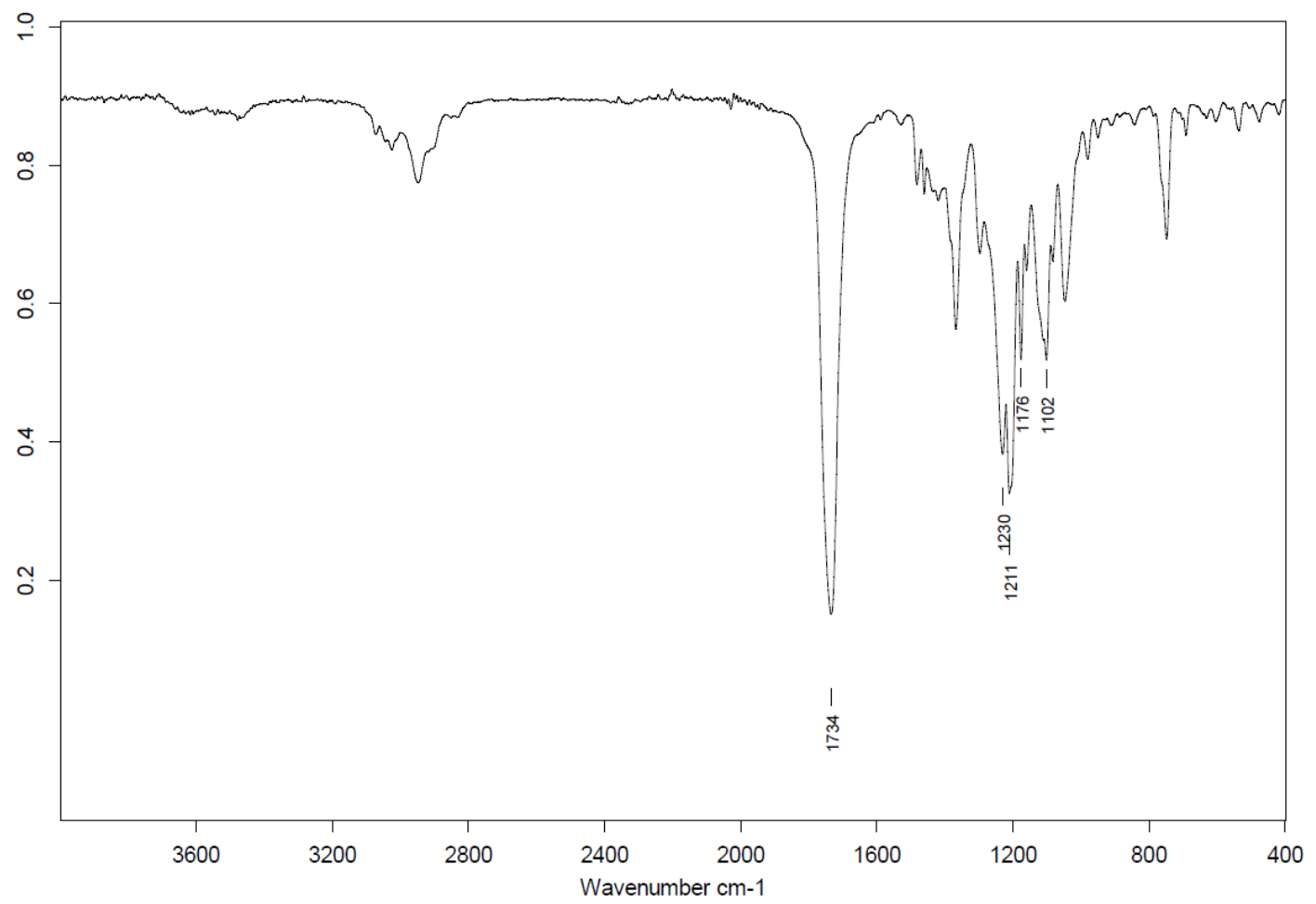




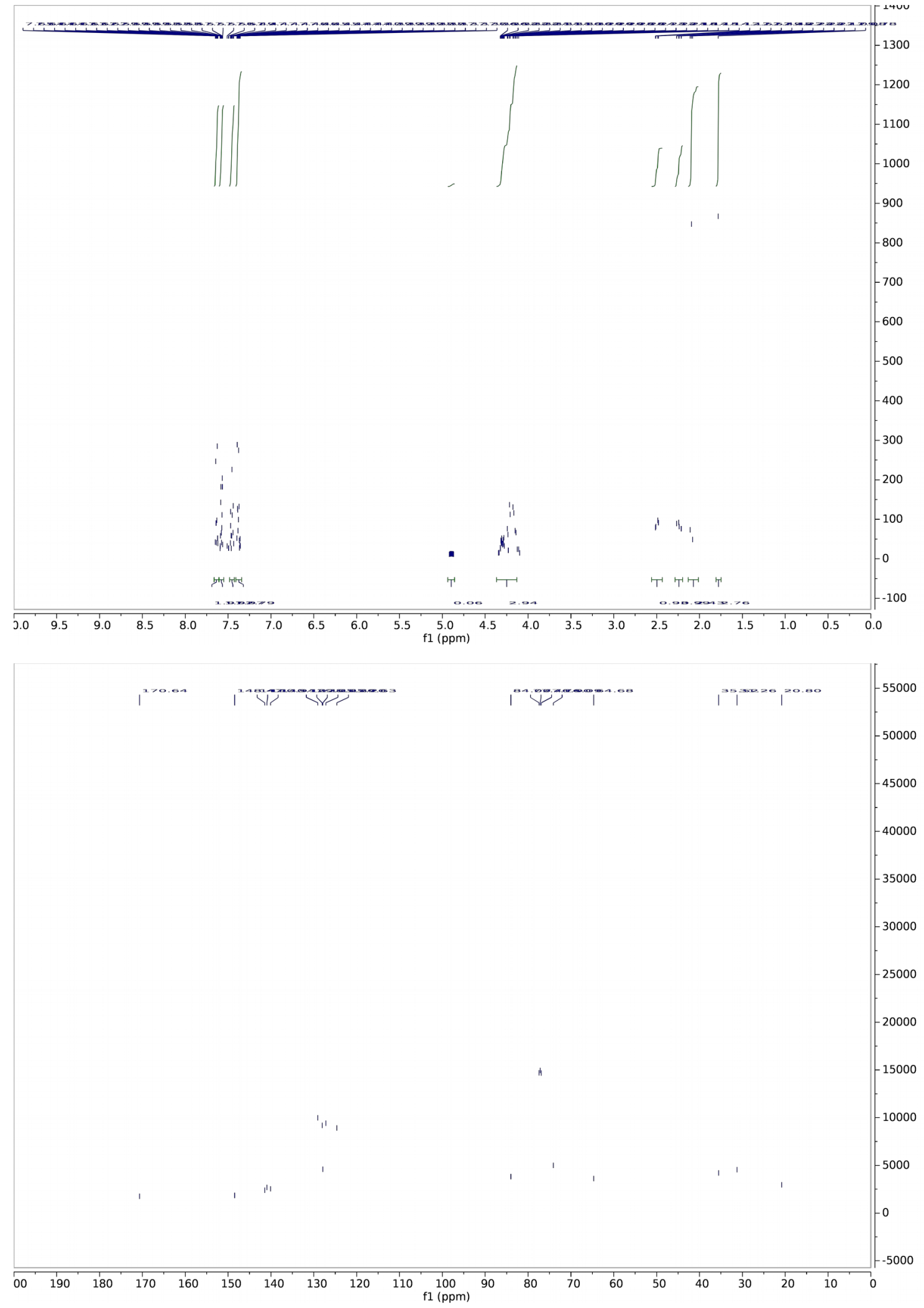




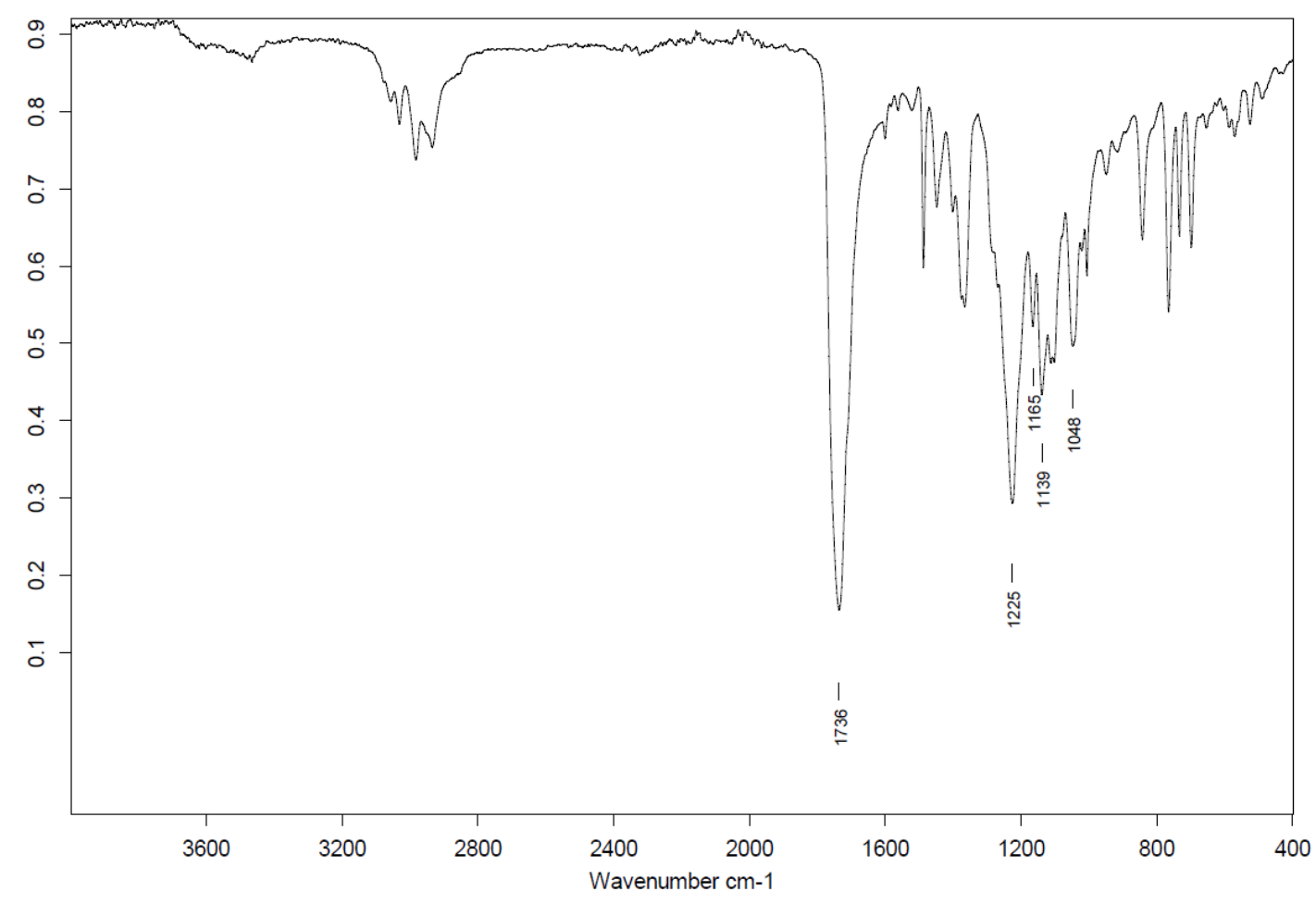


Spectra for tetrahydrofuran derivative 3a:

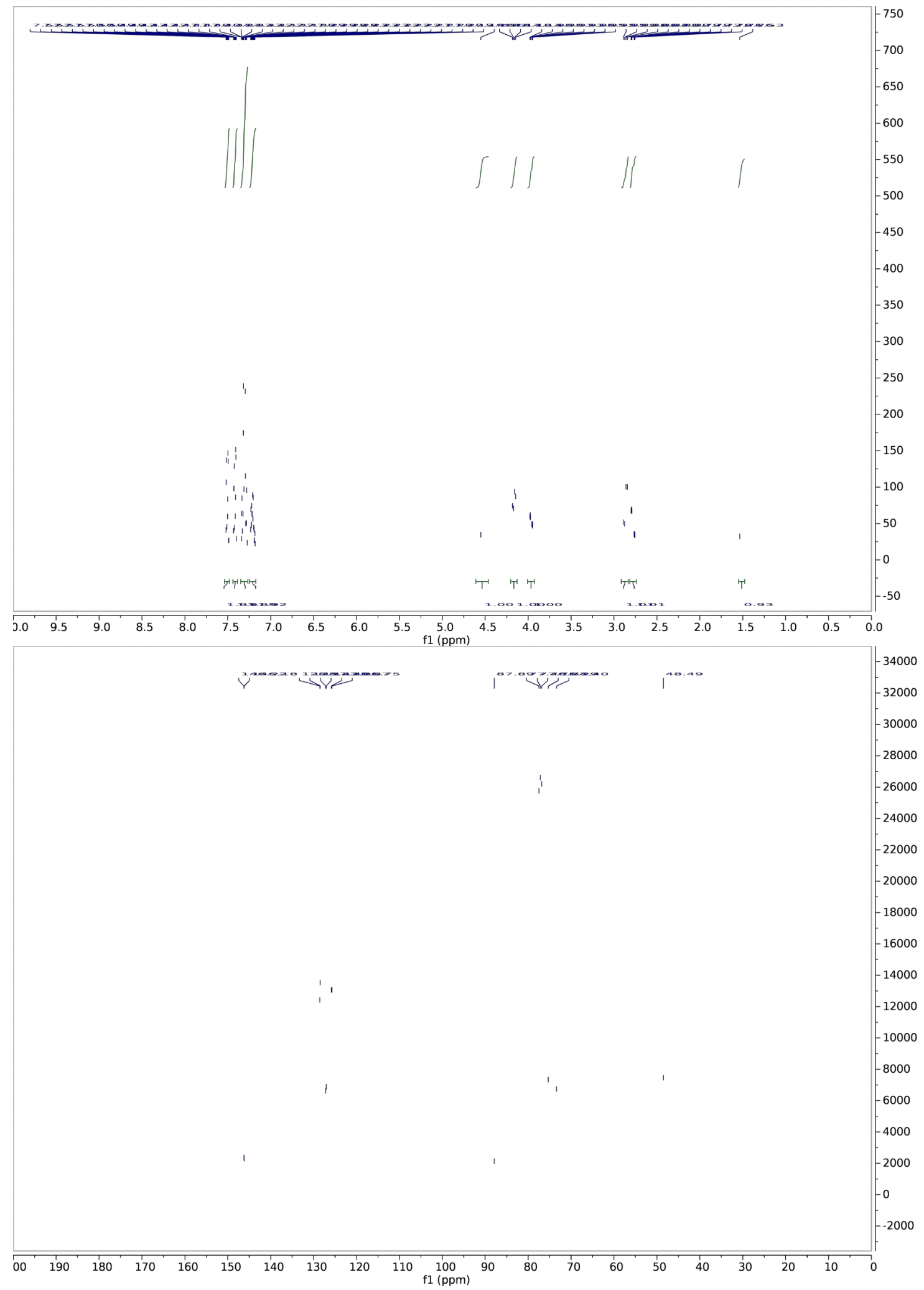


Spectra for tetrahydrofuran derivative 3l-Ac:

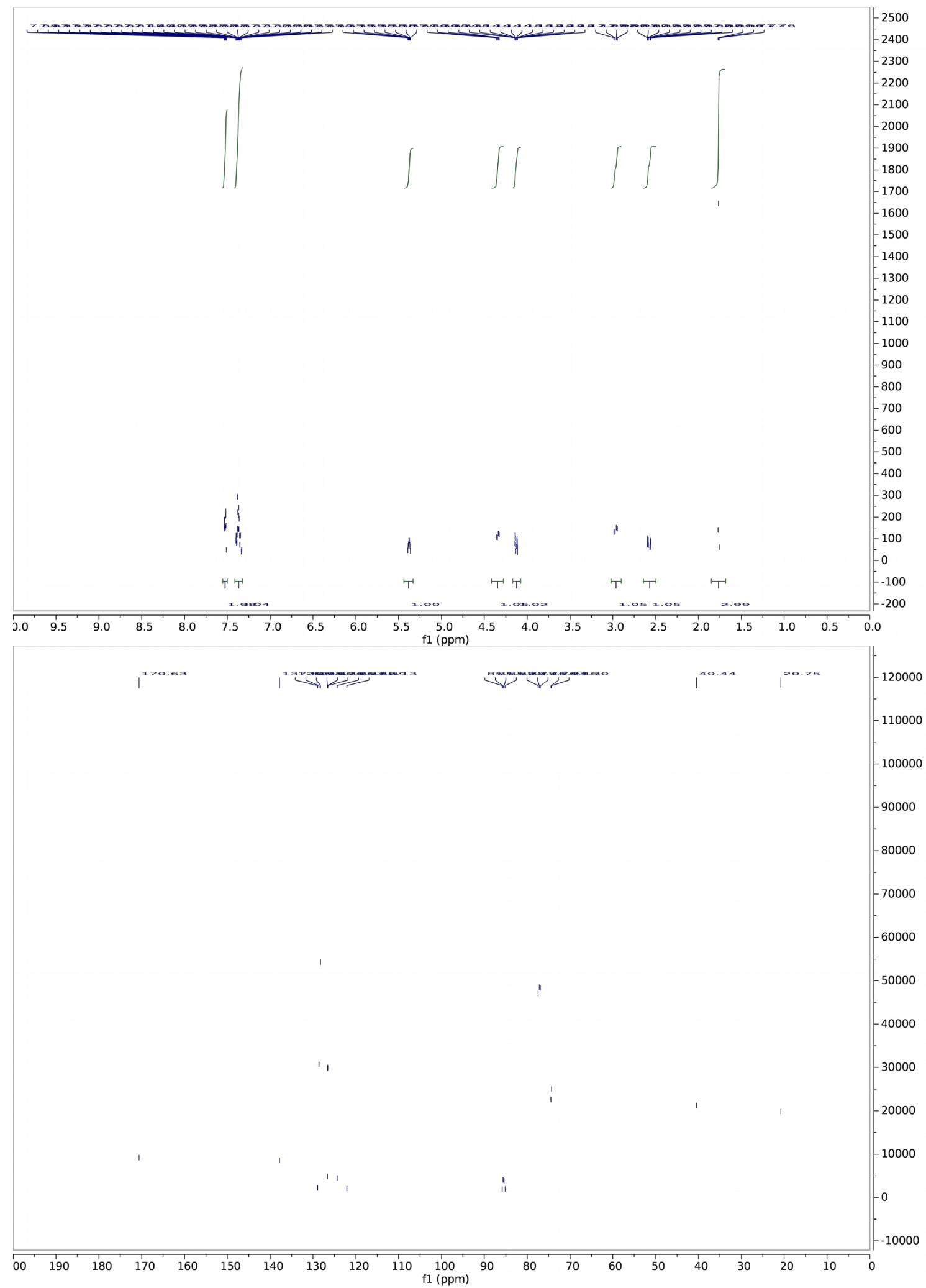



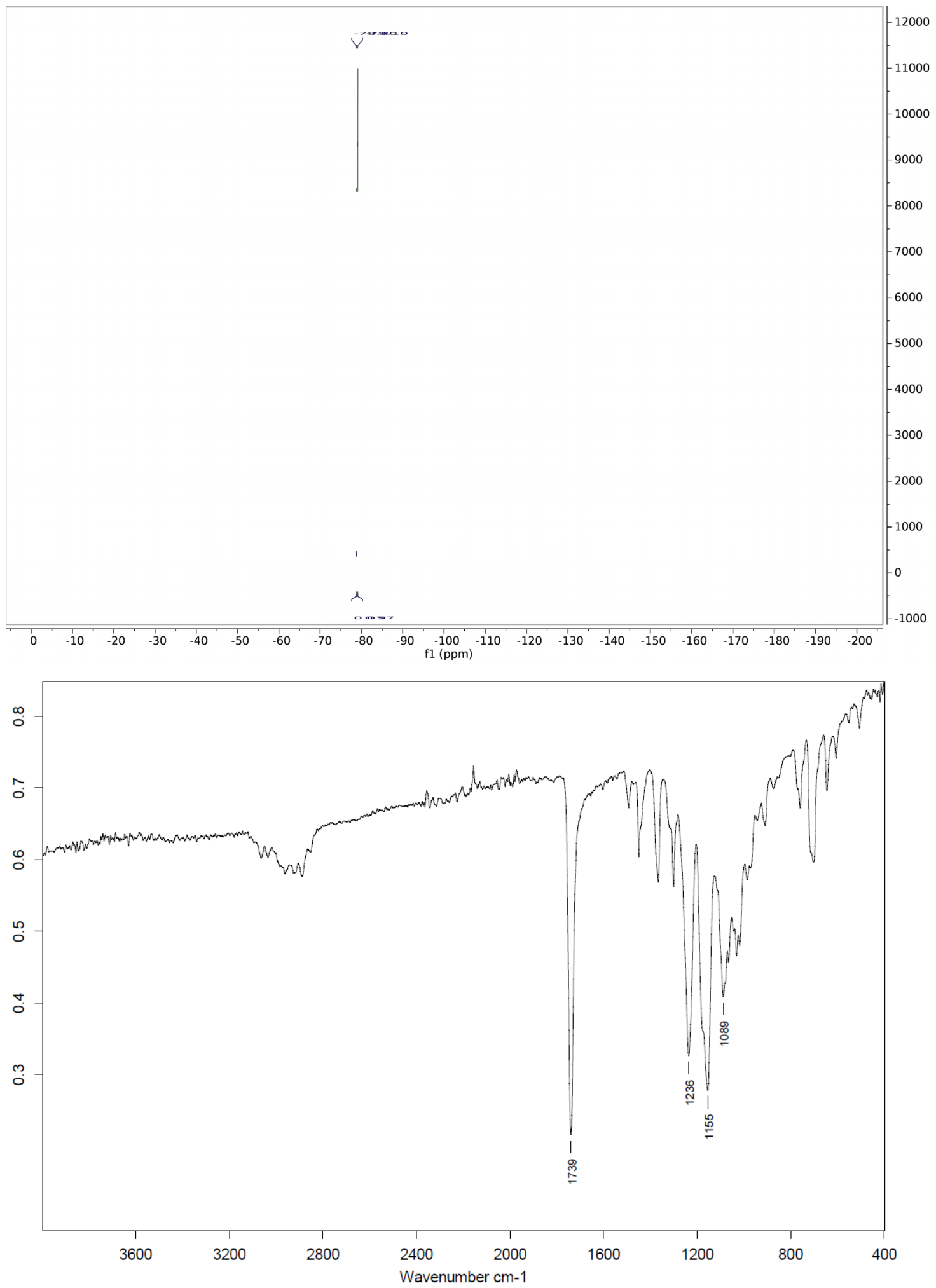
Spectra for tetrahydrofuran derivative 3o:

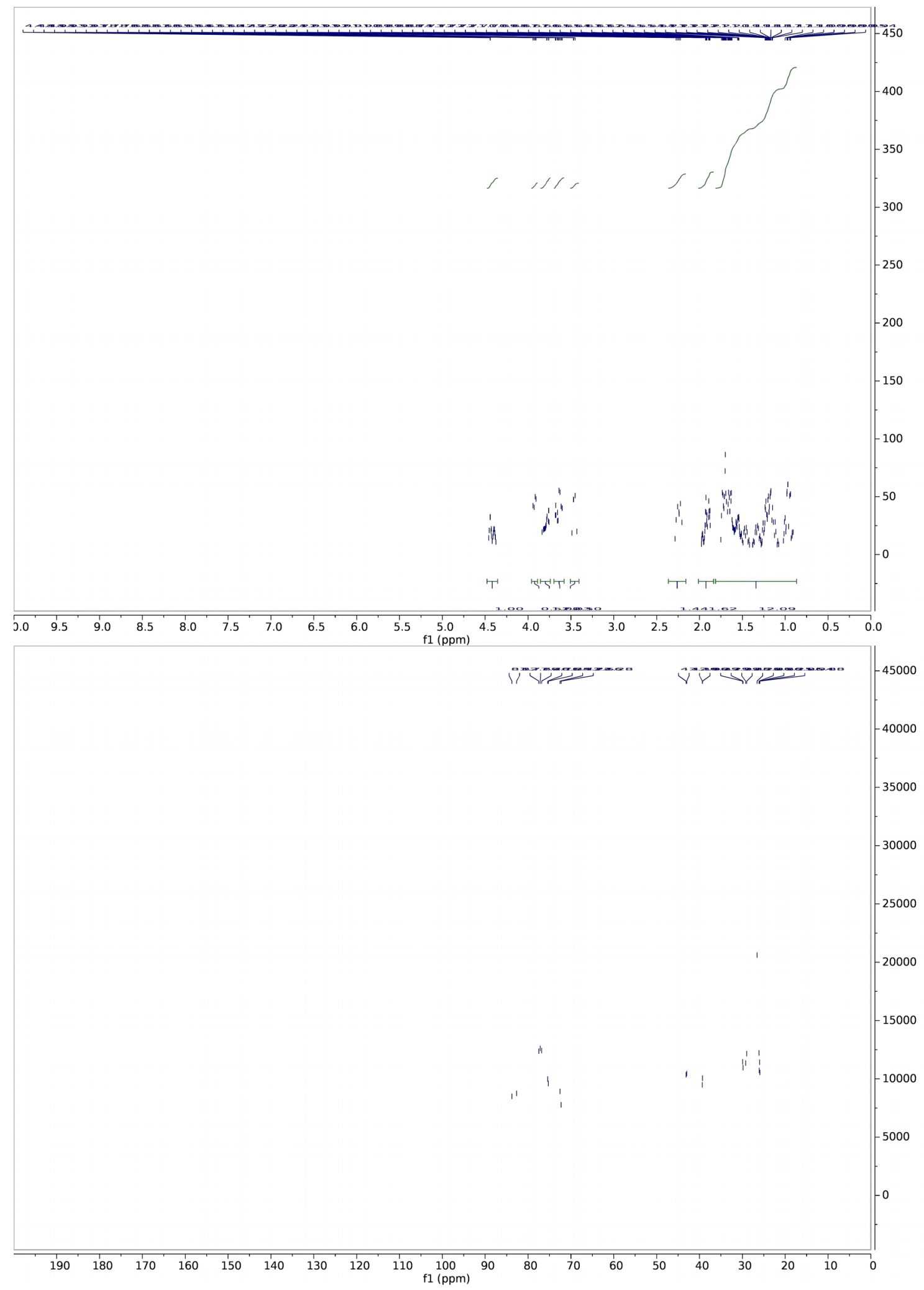




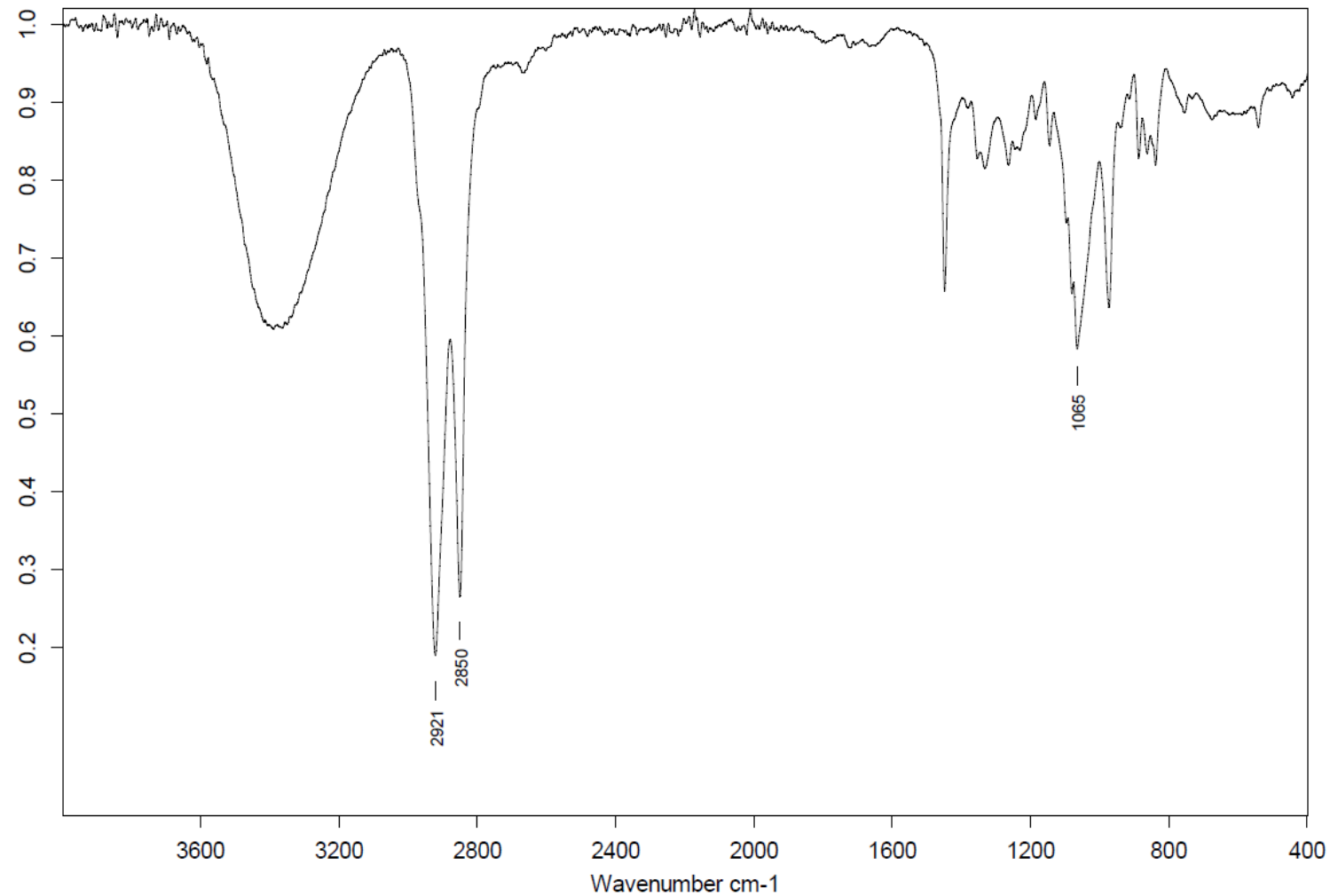


S151: X-ray molecular structure of $2 p$

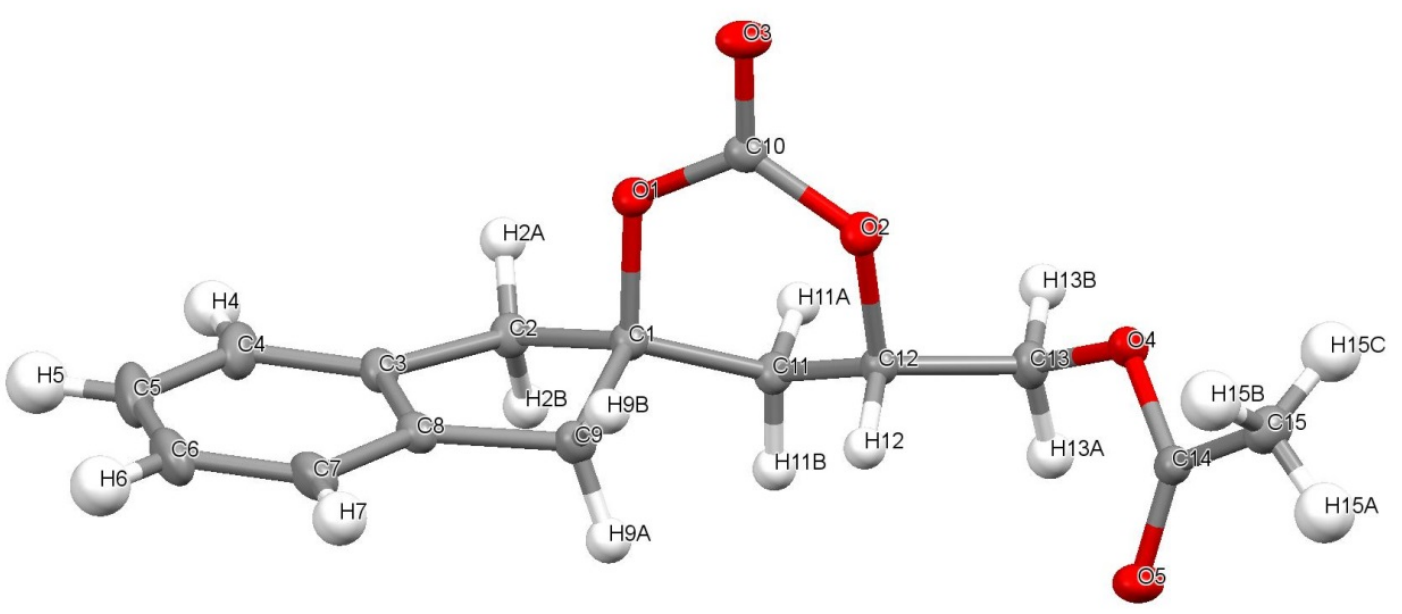

For more details see CCDC-1997736 


\section{S152: Computational acylation of 5MCC-OH (1a)}

The acylation of the 5MCC-OH (1a) having a tertiary $\mathrm{OH}$ group was calculated using the same acylation method/steps as reported in Figure 1 (main text) for 6MCC-OH. These additional studies were performed to elucidate why under the optimized experimental conditions for the preparation of 6MCC-OAc (2a), no acylated 5membered carbonate could be detected (see Figure $\mathbf{S 1}$ below).

Figure S1: Relative Gibbs free energy profile in $\mathrm{kcal} \cdot \mathrm{mol}^{-1}$ for the acylation of $\mathbf{5 M C C - O H ~ ( 1 a ) . ~}$ Note that the acylation pathway for 6MCC-OH is provided in the main text.

The $\Delta \Delta \mathrm{G}^{\ddagger}$ between the two pathways leading to either 5MCC-OAc and 6MCC-OAc (2a) were compared. Both pathways begin with the same reactant 5MCC-OH (1a).

Note that the acylation of 6MCC-OH involves first the isomerization of 5MCC-OH (1a) to 6MCC-OH:

Figure $\mathrm{S} 1: \Delta \mathrm{G}^{\ddagger}=24.8 \mathrm{kcal} \cdot \mathrm{mol}^{-1}$

Figure $1: \Delta \mathrm{G}^{\ddagger}=17.6 \mathrm{kcal} \cdot \mathrm{mol}^{-1}$

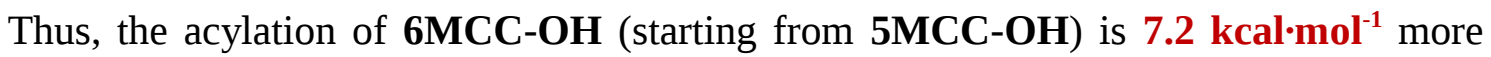
favored, and provides a rationale for the exclusive observation and formation of $\mathbf{6 M C C}$ OAc at rt. 


\section{S153: Relative Gibbs free energy and potential energy profiles}

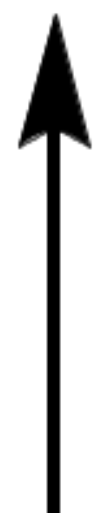

Figure S2 : Relative Gibbs free energy (black) and potential energy (purple) profiles in $\mathrm{kcal} \cdot \mathrm{mol}^{-1}$. This is the entire mechanism that involves both the isomerization of 1a and acylation towards the formation of $\mathbf{2 a}$.

Figure S3: Relative Gibbs free energy (black) and potential energy (purple) profiles in $\mathrm{kcal} \cdot \mathrm{mol}^{-1}$. This is the acylation mechanism for $\mathbf{5 M C C - O H ~ ( 1 a ) . ~}$ 


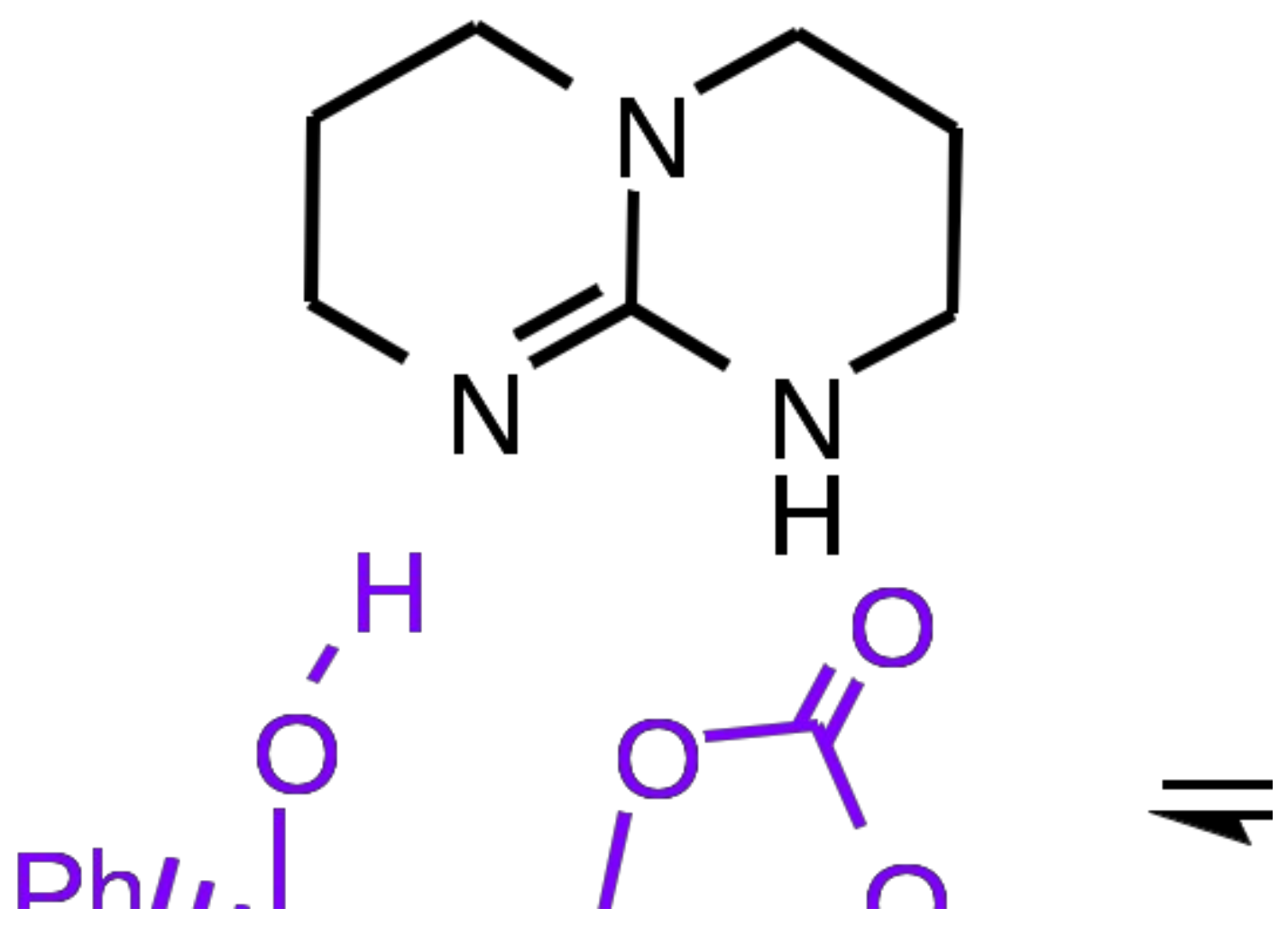

Full access to the computational data can be achieved through the following link: http://dx.doi.org/10.19061/iochem-bd-1-171 
